\title{
Synthèses
}

\section{Innovation and development in agricultural and food systems}

Guy Faure, Yuna Chiffoleau, Frédéric Goulet, Ludovic Temple and Jean-Marc Touzard, editors Afterword : Gaël Giraud

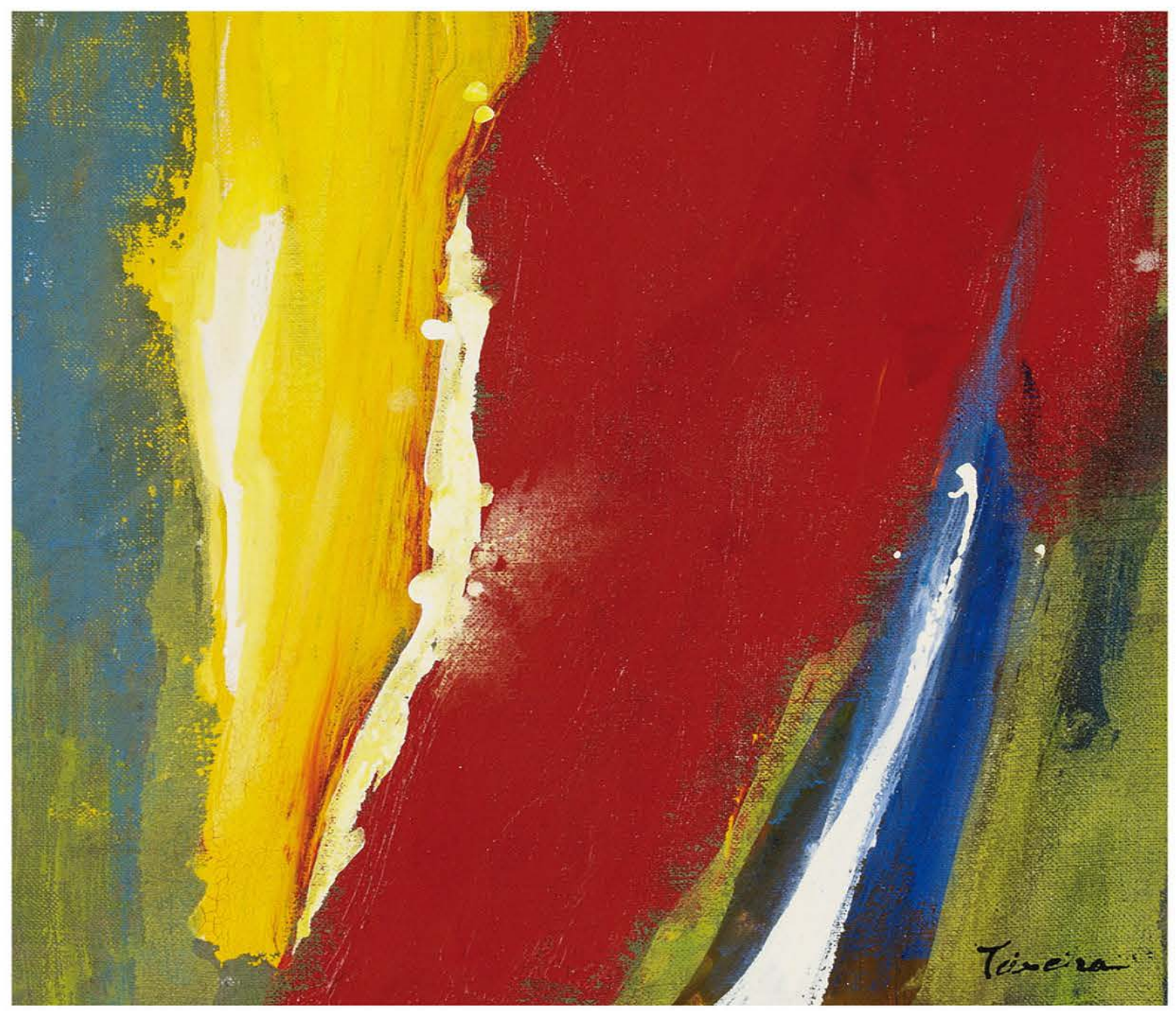




\section{Table des matières}

\section{Couverture}

\section{Innovation and development in agricultural and food systems}

Introduction - Reviving perspectives on innovation in agriculture and food systems

Innovating to survive in the contemporary world Including agricultural innovation in societal debates

Analysing innovation as a multidimensional process

Studying and supporting innovation in agriculture

Structure of the book

Bibliography

Part 1 - Renewing agricultural approaches

Chapter 1 - A history of innovation and its uses in agriculture

Chapter 2 - Agricultural and agrifood innovation in the 21 st century: maintaining, erasing or reshaping its specificities? 
Chapter 3 - Agricultural research and innovation: a socio-historical analysis

Part 2 - Forms of innovation in agriculture and the food sector

Chapter 4 - Agroecological innovation: mobilizing ecological processes in agrosystems

Chapter 5 - Social innovation through short food supply chains: between networks and individualities

Chapter 6 - Innovation, a precondition for the sustainability of localized agrifood systems

Chapter 7 - Territorial innovation in the relationships between agriculture and the city

Part 3 - Providing support to the actors of innovation

Chapter 8 - Designing and organizing support for collective innovation in agriculture

Bibliography

Chapter 9 - Action research in partnership and emancipatory innovation

Chapter 10 - Co-designing technical and organizational changes in agricultural systems 
Chapter 11 - Advice to farms to facilitate innovation: between supervision and support

Chapter 12 - The ComMod and Gerdal approaches to accompany multi-actor collectives in facilitating innovation in agroecosystems

Part 4 - Evaluating the effects of innovations

Chapter 13 - The abattoir, from the factory to the farm. Ethics and morality in the dynamics of innovation in agrifood systems

Chapter 14 - Evaluating the impacts of agricultural innovations

Chapter 15 - Evaluating impacts of innovations: benefits and challenges of a multi-criteria and participatory approach

Chapter 16 - Simulation tools to understand, evaluate and strengthen innovations on farms

Afterword - What types of innovation for sustainable agriculture?

What technological avenues?

Financial environment 
Biodiversity and the commons

List of authors 


\section{Innovation and development in agricultural and food systems}

Guy Faure, Yuna Chiffoleau, Frédéric Goulet, Ludovic Temple AND Jean-Marc TouZARD, EDITORS

(C) Éditions Quæ, 2018

ISBN ePub: 978-2-7592-2960-4

Éditions Quæ

RD 10

78026 Versailles Cedex

Qüa

WwW.quae.com ${ }^{x}$

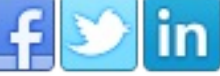

This ePub has been published under the Creative Commons 2.0 Licence.

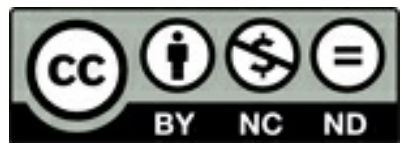

Pour toutes questions, remarques ou suggestions : quae-numerique@quae.fr $\underline{x}$ 


\section{Introduction \\ Reviving perspectives on innovation in agriculture and food systems}

Guy Faure, Yuna Chiffoleau, Frédéric Goulet, Ludovic Temple and JeAn-Marc Touzard

Innovation has become an essential issue for our societies. It is ever-present in the discourses of economic and political actors and is the subject of dedicated policies. New structures such as clusters and platforms are built around it, and it is now incarnate in the figure of the contemporary hero, the creator of the start-up. The issue of innovation has also gained an important place in the scientific world, as shown by the growing number of studies and research activities devoted to it, the creation of learned societies and specialized journals testifying to the legitimization of an academic field on innovation studies (Fagerberg and Verspagen, 2009; Godin, 2014).

\section{Innovating to survive in the contemporary world}

Much more than a fashionable notion or buzzword, innovation has become a key issue for companies, policies and, more generally, society. In the Global North as in the Global South, innovating, i.e. introducing a novelty in an economic and social environment, appears more than ever as a factor of competitiveness for enterprises, leading to cost reductions, improved productivity or product quality, or the creation of new markets in a context of globalized competition (Porter and Heppelmann, 2014). In an extension of Schumpeter's (1934) work, innovation is more widely reaffirmed as a source of macro-economic growth, at the heart now of a 'knowledge economy', deriving value from creativity, learning and communication (Foray, 2004; Stiglitz and Greenwald, 2014). It is also put forward as a solution to the problems generated by economic development itself, especially in the 
ecological, energy and food fields, leading to what Callon et al. (2015) call a regime of the economy of techno-scientific promises. Finally, across frontiers opened up by new technologies, in the digital and biotechnology fields for example, innovation is envisaged as the possible catalyst of a more radical social transformation, moving the world towards increased knowledge sharing (Rifkin, 2011), transhumanism (Ferry, 2016) and a break with the current forms of capitalism (Latouche, 2006).

Of course, critical points of view question this craze for innovation (Godin and Vinck, 2017; Petit, 2015). Both creative and destructive, innovation can lead to social exclusion, destroy jobs and businesses, result in monopolies and misappropriations, and generate new technical and societal risks that need to be understood and addressed (Joly et al., 2015; Temple et al., 2018). But these critics often end up relying on the notion of innovation itself to suggest, or sometimes rehabilitate, alternative paths or avenues of resistance, for example through innovations qualified as 'social' or 'frugal'. Whether in the scientific, political, industrial arenas, or more broadly those of entrepreneurship and the media, innovation appears as a notion that is open to analysis, encouragement and criticism regarding societal changes. But it is also capable of underpinning the transformations of our contemporary societies.

This primacy of innovation seems to have won over every corner of society, attracting attention, debate and engagement in all its economic sectors. It is in this context that this book presents contemporary perspectives on innovation in one of these sectors: agriculture and food. Several books and collection of studies have helped shed light on the issue of innovation in agriculture from different disciplinary and geographical perspectives (Chauveau and Yung, 1993; INRA and École des Mines, 1998; Rajalahti, 2012; Coudel et al., 2013; Touzard et al., 2014). But very often, for the scientific community studying innovation, agriculture is just one sectoral study case among many others, alongside health or transport, even if issues specific to agriculture can be raised (Malerba, 2006; RRI, 2014). This book aims to present an up-to-date reflection on the specificities of innovation in the agricultural and food sectors, in the backdrop of the reconfigured relationships between agriculture, food and human societies. 


\section{Including agricultural innovation in societal debates}

The issue of innovation in the agricultural and agrifood sectors is indeed the subject of many debates reflecting the transformations of contemporary societies, moving the traditional boundaries between countries of the Global North and those of the Global South, between the rural and the urban, and even between economic growth and social development. These debates lead to the politicization of innovation and to the revitalization of its approaches at several levels.

A first level concerns political and ethical debates on which innovations to favour and which to reject. The criteria for what is or is not a 'good' innovation vary across societies, social groups, and historical periods. In the agricultural sector, biotechnology and genetically modified organisms are apt illustrations of these debates and the manner in which they can divide societies. Where some see a sign of progress and, for example, a way of reducing the use of pesticides or of improving food production, others see only a strategy to increase the profits of multinational firms, reduce the farmers' autonomy or jeopardize the gene pool (Bernard de Raymond, 2010). Debates swirl around not only the proven impacts of innovation, but also the different types of risks (social, economic, health, etc.) associated with it (Beck, 2001). Given that an innovation cannot be considered good just because it is an innovation and, depending on the criteria selected and the importance accorded - or not - to certain types of impacts, it is the very nature of innovations which becomes open to debate.

A second level of debate concerns the aims of innovation, in a context subject to new local and global challenges. During the 20th century, innovation was implicitly and, later, explicitly part and parcel of the idea of economic growth and progress. Today however, it asserts itself as a process with a plurality of goals, responding to the major challenges that confront societies and public policies. Food security, the maintenance of biodiversity and the fight against pollution and climate change are representative examples of these major challenges, sparking an exponential number of initiatives and, consequently, innovations. These goals are themselves open to debate, sometimes revised, hierarchized, or recombined in political processes. Thus, climate-smart 
agriculture, promoted by the FAO (2013) to encourage the adoption of agricultural innovations meant to address climate and food security challenges, finds itself being subjected to debate, because it is suspected by some countries and non-governmental organizations of being an attempt at greenwashing and an example of the dissemination of technologies controlled by industrialized countries.

These debates on the aims of innovation lead to others on the targets of innovation. Behind this third level of debate are often reflections, expounded upon in abundant literature, on improving the performance of enterprises (upstream or downstream firms, farms). In reaction, or in parallel, other reflections stress the necessity of channelling the efforts devoted to innovation, whether originating from the public sector or the private sector, in favour of populations that are economically or socially the most vulnerable, such as the policies incentivizing innovation for family farming in Latin America (Goulet, 2016). The idea is that the benefits accruing to some people due to innovation do not necessarily reach others through a trickle-down effect. However, the risk is that this line of thinking will end up supporting a vision of innovation by categories of targets (rich vs poor) or markets (effective $v s$ ineffective), denying the natural interdependencies between processes and the need for transversal and encompassing approaches (Klein et al., 2014).

A fourth discussion level takes the previous one a little further and raises the issue of who is doing the innovating. While Schumpeter (1934) theorizes the innovative entrepreneur, and innovation analyses generally accord value to the inventions of researchers and engineers, the innovative capacity of other actors (especially farmers, artisans and consumers) often remains little recognized. A series of debates have then followed around studies refuting their role as simple receptacles or beneficiaries, and highlighting, in the agricultural sector in particular, endogenous, local, or even peasant innovation, sometimes at the risk of advocating a populist approach (Thomsons and Scoone, 1994). While this encompassing or restrictive recognition of innovators has a mainly symbolic and political value, very often it also becomes a key factor when an effective collective response to a development issue has to be formulated. 
These considerations open up a last level of debate, around the 'how': How does innovation emerge? How should it be conceived? How to support and evaluate it? It is no longer the innovations themselves that are under discussion, nor their goals, nor even their beneficiaries or their originators, but the way to develop them and make them emerge. This debate is mainly centred around the contestation of the so-called 'top-down' models of innovation[1], which have had a profound impact on agricultural development (Chambers, 1983; Darré, 1999). The general idea is instead to involve a growing number of heterogenous actors in the development of innovations, and to create a new innovation regime, one that is more democratic and based on collective experimentation (Von Hippel, 2005; Callon et al., 2015). This idea is gaining ground, even in the public policies concerning the agricultural sector, and is reflected in particular in a better identification of the innovations produced by farmers on their farms and by the creation of local innovation platforms and territorial 'living labs'[2]. The 'right' way of innovating thus becomes the subject of debate, of research, and of contrasting positions taken by different actors concerned by agricultural and food issues.

\section{Analysing innovation as a multidimensional process}

The perspectives on agricultural innovation presented in this book draw inspiration from these different debates and help enrich them while analysing them. But these perspectives are also based on a large corpus of recent academic contributions in economics, management, sociology, geography and agronomy, all areas that share common approaches to innovation, and which are found in two important multidisciplinary scientific communities: 'Innovation Studies' and 'Science and Technology Studies'[3].

More than the mere introduction or adoption of a novelty in a socio-economic system, innovation is analysed in the work of these two communities, across all disciplines, as a process that results from the interactions between several actors, intervening in a given context and reflecting an intention to change. While innovation can certainly be characterized in different ways depending on its purpose (a product $v s$ a process), its nature (technical vs organizational, ad-hoc vs systemic, etc.) or the characteristics of its emergence and its 
deployment in the system under consideration (radical vs incremental, endogenous vs exogenous, top-down vs bottom-up, etc.), it always results, in fact, from the synergy between three dimensions: technical, organizational and institutional. Thus, Leeuwis and Van den Ban (2004) believe that an innovation combines the implementation of new techniques and practices (constituting the 'hardware'), new knowledge and ways of thinking ('software') and new institutions and organizations ('orgware'). The work of the sociologists of the École des Mines in France in the 1980s, and their contributions to actor-network theory (Akrich et al., 1988a,b), for their part, emphasized the socio-technical dimensions of innovations, encouraging researchers to overcome technical or social reductionisms in the analysis of innovation processes.

In line with Schumpeter's (1934) approaches, many current approaches to innovation also believe that entrepreneurs play a key role because they seize opportunities to innovate by taking risks. This role of the entrepreneur manifests itself in agriculture through the farmer who innovates (Chauveau et al., 1999) or through the entrepreneur acting under the organizations' radar (Hall and Dorai, 2012). But even more than through these individuals, sometimes called 'champions of innovation', it is through the construction of knowledge and capacities within networks of actors that innovation in agriculture takes place (Klerkx et al., 2010). These formal or informal networks can be characterized by a set of more or less close relationships between individuals and/or organizations. A wide range of collective and individual learning processes take place in order to produce knowledge that can be useful in bringing about the desired change (Faure et al., 2014). The function of intermediation (or facilitation) between actors is thus fundamental (Klerkx et al., 2010) to stimulate interactions, encourage negotiations, mobilize resources, help novelties emerge or be rediscovered, or allow the capitalization of experiences. The networks' configuration changes continuously during the innovation processes, favouring the creation of new links but causing some others to disappear.

Innovation is thus understood as a complex, constantly changing and unpredictable process, which is difficult, if not impossible, to control (Akrich et al., 1988a,b; Leeuwis and Van Den Ban, 2004). Indeed, every innovation process experiences accelerations, slowdowns and crises, and since 
innovations are subject to a selection mechanism, they are not all viable (Nelson, 1993). But the complexity of the process can also be studied using frameworks that delineate its trajectory, characterize different phases or moments of the innovation, and identify its stylized sequences. The recourse to actor-network theory thus refers to the stages of problematization, engagement, enrolment and mobilization of actors (Akrich et al., 1988a,b). Studies on innovations in socio-technical transitions (Geels and Schot, 2007) show how they can emerge in niches that allow them to mature or, on the contrary, hasten their elimination, then expand, spread in their original form or in a new form and, ultimately, modify the dominant socio-technical regimes. Institutional and macro-economic environments thus play an important role, through the rules, norms and values that either support the dominant trajectory or allow the emergence and development of niche innovations.

Innovation can also be analysed in the more structured framework of national, regional or sectoral innovation systems promoted by innovation studies (Martin, 2012). Schematically, an innovation system aims to encompass, at the same time, the actors, networks, knowledge and institutions that influence innovation in a given space. It includes all the actors contributing to the innovation, i.e., the research community, intermediate actors, professional organizations, companies, the State with its public policies, etc. In this perspective, innovation results from the application of the outputs of scientific research only in some cases. Moreover, when the research community is involved in an innovation, there are many iterations between researchers and their partners, until they achieve one or more innovations, deployed by other categories of actors (farmers, firms, organizations). Such an analysis, in terms of innovation systems, makes it possible to examine not only development processes and innovation policies, but also the impacts of innovations (Klerkx et al., 2010; Touzard et al., 2014).

\section{W Studying and supporting innovation in agriculture}

In this book, we want to examine and enrich the perspectives on innovation 
specifically in agriculture and the food sector. We do so by basing ourselves on the substantial body of recent research on innovation across disciplines. By using reviews and analyses of case studies undertaken in Europe and in many countries of the Global South, we aim to fulfil a twofold ambition. The first is to offer an update on the state of progress on themes for which the issue of innovation is key, especially in connection with the periodisation of the major transformations of the agricultural sector and with regards to major societal challenges. The second ambition is to present a posture that research on innovation can adopt, at the intersection of analyses that contribute to societal debates and support for addressing societal challenges.

This book's contributors all share a systemic approach to innovation, forged and translated into multidisciplinary research practices within the same research unit, the 'Innovation' joint research unit[4] in Montpellier, France. A common analytical approach and framework for innovation in agricultural and food systems has thus been constructed from a triple perspective. The first is to identify, study, characterize and describe accurately the mechanisms that lead to innovation. The aim is to produce factual knowledge, concepts and analytical frameworks whose scope is generic, sometimes applicable outside the agricultural and rural sectors. It is also a matter of qualifying innovation models and evaluating the impacts of these innovations. The second perspective is to use situations of innovation or, more generally, of change, as advanced observation posts to understand and characterize agricultural transformations. Innovation processes are in fact spaces of imbalance, transformation and rearrangement, a window on how actors act, how resources are used and transformed and, ultimately, how agricultural and food systems evolve. The third perspective aims to support actors who innovate, not only through participatory research or action research, but also by developing methods to encourage the emergence, deployment and adoption of innovations at the scale of the farm and of groups of heterogeneous actors, and to build the capacities of these actors to innovate.

By maintaining these three perspectives, researchers can contribute to academic and societal debates with original analyses that are useful in conceiving innovations with the actors of agricultural and food systems. Such research efforts can lead to reflection support tools for these actors and to methods of intervention for support mechanisms, help strengthen research 
and development or advisory organizations, and participate in the development of innovation and research policies. This book addresses all of these considerations in four parts, whose contents we describe in greater detail below.

\section{Structure of the book}

\section{History and positioning of studies on innovation in agriculture}

The book's first part provides an overview of the thinking on innovation in agriculture from a historical perspective, which culminates by taking into account the current and major societal challenges of our time.

Chapter 1 explores the history of innovation and its uses in agriculture by dividing the past into three distinct periods, based more specifically on the perspectives and contributions of economics and sociology. Until the Second World War, the concept of innovation was little used and it was instead the issue of technical progress that took centre stage. Over the next four decades, diffusionist approaches to innovation dominated the research world, before the emergence, starting in the 1980s, of criticism of the agricultural development model and of a shift in thinking about innovation.

In Chapter 2, the current characteristics of innovations in agriculture and food systems are analysed by examining their sectoral specificities, which are based on the relationships that agricultural and food activities have with nature, space and societies. These innovations are also characterized today by the convergence of global challenges as shown by research regarding transitions, be they ecological, climate-driven, digital, social or concerning food.

Chapter 3 shows that science and technology contribute to the transformation of agricultural worlds through the creation of national and international agricultural research institutions during the latter half of the 20th century. In particular in the context of a crisis of confidence in the industrial agricultural 
model and of transformations specific to the scientific field, these institutions are being compelled to re-draw the contours of their contributions to innovation.

\section{Current forms and figures of innovation}

The second part examines the different visions of innovation according to different disciplinary points of view (agronomy, geography, economics, management, sociology). It also examines them according to different innovation domains (production systems, food systems, organizations, territory).

Chapter 4 discusses agroecological innovation and shows that the characteristics inherent to agroecology make it a distinct process of innovation, leading to a revamping of approaches and of support and advisory services provided to farmers.

Chapter 5 identifies the food sector as conducive to social innovations, which in particular help to address issues of access to good quality food by people in vulnerable situations. Social innovation is then understood as a relationship-based and contextualized process, built over time by singular individuals, and supported by mediation resources.

Chapter 6 shows that localized agrifood systems (LAFS) have a constant need for technical and organizational innovations. By providing an understanding of LAFS, this chapter sheds light on these collective and localized innovation processes that involve farmers and small agrifood businesses, and identify ways of supporting the actors involved.

Chapter 7 mobilizes the concept of territorial innovation to apprehend the multiple dimensions of the relationships between agriculture and the city and thus to understand the transformations of agriculture in the context of urban society. Innovation becomes territorial through the accumulation of microchanges that end up influencing the practices of urban and rural actors, as well as the uses and norms that regulate the relationships between agriculture and the city. 


\section{Innovating in supporting and accompanying innovation}

The third part focuses on supporting innovation, by discussing the diversity of research and advisory services that aim to promote innovation, and by proposing methods of intervention to support processes of innovation involving farmers or heterogeneous groups of actors. The research presented in this third part is based on analyses and experience gained from working for several years with advisory and support actors.

Chapter 8 thus discusses the different functions of existing innovation support systems, especially in the Global South. The authors show that a variety of mechanisms is necessary to create conditions favourable to innovation and to support collectives step by step, depending on their capacities and their learning needs.

Chapter 9 shows why and how researchers associate with non-researcher actors who are engaged in the transformation of reality in an action research in partnership in order to build knowledge production mechanisms with them. Action research in partnership can be seen as an innovation because it involves significant changes in research mechanisms, most notably of their governance, methods and practices.

Chapter 10 presents approaches to co-design innovative farming systems based on a high level of interactions between the actors involved. A range of intermediary objects, such as modelling or on-farm experimentation, are used to facilitate these interactions and to promote learning.

Chapter 11 discusses the evolution of agricultural advisory services and the variety of methods for providing it. It shows that the choice of an advisory method depends not only on the nature of the problem to be addressed and the solutions to be implemented, but also on the capacities of the advisers, the objectives set by advisory organizations and the mechanisms for the governance and funding of agricultural advisory services.

Chapter 12 deals with the support or 'accompaniment' of multi-actor collectives to facilitate innovation by comparing two intervention approaches. 
These approaches aim at facilitating the emergence of solutions and action plans negotiated within peer groups or arenas of heterogeneous actors. The chapter analyses the points common to these approaches as well as their differences to draw lessons for the support of such collectives.

\section{Evaluating the effects of innovation on the dynamics of development}

The fourth and last part of the book covers the evaluation of the effects of innovations on the dynamics of development, starting with questions of purpose and ethics, and going on to issues concerning methods of evaluation used to measure the effects.

Chapter 13 aims to clarify the place of morality and ethics in innovation processes. The evaluation focuses in particular on the actors' moral judgments. In support of the results of an action-research approach on alternatives to the industrial slaughter of farm animals, the chapter shows how livestock farmers place their moral responsibility for their animals at the centre of an innovation process: on-farm slaughter.

Chapter 14 discusses the demands by donors, national research and development agencies and civil society actors for the evaluation of research and development programmes. It presents the different evaluation methods that can be used, as well as the trade-offs to be made in order to choose the approach that is most appropriate for the innovation under study and for the issues raised by the evaluation.

Chapter 15 discusses multi-criteria evaluation tools to explore the effects and impacts of technical and organizational innovations. It discusses three methodological issues: the taking into account of the multiple dimensions of innovation, actor participation in identifying and developing evaluation criteria and indicators, and the manner in which to arrive at a final assessment through the choice of measurement methods.

Chapter 16, the last chapter, presents ex ante and ex post evaluations of agricultural production systems using computer tools (simulation, modelling). When used ex post, these tools make it possible to evaluate the effects of 
adopting an innovation on the performance of existing farms. When used ex ante, these tools become aids to dialogue and decision-making, and make it possible to test different scenarios with farmers and technicians.

The four parts of this book present the research of scientists from different disciplines, and show the collective dynamics at work within a joint research unit. Research laboratories, just like groups of actors associated with innovation processes, are composed of diverse individuals, differentiated by their functions, their approaches and their perceptions of ground realities. In both cases, it is precisely this pluralism and the interactions it generates that make it possible for novelties to emerge in the form of new ideas, new research practices and new products. We hope that you, the reader, find this book stimulating and useful.

\section{Bibliography}

Akrich M., Callon M., Latour B., 1988a. À quoi tient le succès des innovations. Premier épisode : l'art de l'intéressement. Gérer et comprendre, Annales des Mines, 11, 4-17.

Akrich M., Callon M., Latour B., 1988b. À quoi tient le succès des innovations. Deuxième épisode : l'art de choisir les bons porte-parole. Gérer et comprendre, Annales des Mines, 12, 14-29.

Beck U., 2001. La Société Du Risque. Sur La Voie D’une Autre Modernité, Aubier, Paris.

Bernard de Raymond A., 2010. Les mobilisations autour des Ogm en France, une histoire politique (1987-2008). In: Les mondes agricoles en politique (B. Hervieu, N. Mayer, P. Muller, F. Purseigle, J. Rémy, eds), Presses de Sciences Po, Paris, 293-336.

Callon M., Rip A., Joly P.-B., 2015. Réinventer L'innovation ? InnovatiO, 1, [online], <http://innovacs-innovatio.upmf-grenoble.fr/index.php?id=252 $\square>$ (retrieved 29 July 2018).

Chambers R., 1983. Rural Developement. Putting the Last First. Longman, 
New York.

Chauveau J.P., Cormier Salem M.C., Mollard E. (eds), 1999. L'innovation en agriculture, questions de méthodes et terrains d'observation. IRD, Paris, $362 \mathrm{p}$.

Chauveau J.P., Yung J.M, 1993. Innovation et sociétés. Quelles agricultures ? Quelles innovations ?, Actes du XIV séminaire d'économie rurale, volume 2, 13-16 Sept 1993, Montpellier, France, Inra, Cirad, Orstom.

Coudel E., Devautour H., Soulard C.T., Faure G., Hubert B. (eds), 2013. Renewing Innovation Systems in Agriculture and Food: How to go towards more sustainability? Wageningen Academic Publishers.

Darré J.P., 1999. La production de connaissances pour l'action. Arguments contre le racisme de l'intelligence. Éditions de la Maison des sciences de l'homme / Institut national de la recherche agronomique.

Fagerberg J., Verspagen B., 2009. Innovation Studies - the Emerging Structure of a New Scientific Field. Research Policy, 38(2), 218-233.

FAO, 2013. Climate Smart Agriculture Source Book. FAO, Rome.

Faure G., Gasselin P., Triomphe B., Temple L., Hocde H. (eds), 2014. Innovating with rural stakeholders in the developing world - Action research in partnership. CTA - LM Publishers, 224 p. $<$ https://publications.cta.int/media/publications/downloads/1783_PDF.pdf $4>$ (retrieved 13 July 2018).

Ferry L., 2016. La Révolution transhumaniste. Comment la technomédecine et l'ubérisation du monde vont bouleverser nos vies. Plon, Paris.

Foray D., 2004. The Economics of Knowledge. The MIT Press, Cambridge, MA, $287 \mathrm{p}$.

Geels FW, Schot J., 2007. Typology of sociotechnical transition pathways. Research Policy, 36(3), 399-417.

Godin B., 2014. Innovation Studies: Staking the Claim for a New 
Disciplinary Tribe. Minerva, 52(4), 489-95.

Godin B., Vinck D. (eds), 2017. Critical Studies of Innovation: Alternative Approaches to the Pro-Innovation Bias. Edward Elgar, Northampton, MA.

Goulet F., 2016. Faire science à part. Politiques d'inclusion sociale et recherche agronomique en Argentine. Habilitation à diriger des recherches, Sociologie, University of Paris-Est, Champs-sur-Marne.

Hall A., Dorai K., 2012. De quels types d'entrepreneurs innovants avonsnous besoin ? In: Apprendre à innover dans un monde incertain : concevoir les futurs de l'agriculture et alimentation (Coudel E., Hubert B., Devautour H. Soulard C., Faure G., eds), Quæ, Versailles.

Inra, École des Mines (eds), 1998. Les chercheurs et l'innovation. Regards sur les pratiques de l'Inra. Éditions Quæ, Versailles.

Joly P.B., Colinet L., Gaunan A., Lemarié S., Larédo P., Matt M., 2015. Évaluer l'impact sociétal de la recherche pour apprendre à le gérer : l'approche Asirpa et l'exemple de la recherche agronomique. Gérer \& Comprendre, 122, 31-42.

Klein J.-L., Laville J.-L., Moulaert F. (eds), 2014. L'innovation sociale. Eres, Toulouse.

Klerkx L., Aarts N., Leeuwis C., 2010. Adaptive management in agricultural innovation systems: The interactions between innovation networks and their environment. Agricultural Systems, 103(6), 390-400.

Latouche S., 2006. Le pari de la décroissance. Fayard, Paris.

Leeuwis C., Van den Ban A., 2004. Communication for innovation: rethinking agricultural extension. Third edition, Blackwell Publishing, Oxford.

Malerba F., 2006. Innovation and the evolution of industries. Journal of Evolutionary Economics, 16, 3-23.

Martin B.R., 2012. The evolution of science policy and innovation studies. 
Research Policy, 41(7), 1219-1239.

Nelson R., 1993. National Innovation Systems. A Comparative Analysis. Oxford University Press, New York/Oxford.

Petit S., 2015. Faut-il absolument innover ? À la recherche d'une agriculture d'avant-garde. Courrier de l'environnement de l'Inra, 65, 19-28.

Porter M.E., Heppelmann J.E., 2014. How Smart, Connected Products are Transforming Competition. Harvard Business Review, November 2014, 6588.

Rajalahti R., 2012. Agricultural Innovation Systems. An investment source book. World Bank, Washington.

Rifkin J., 2011. The Third Industrial Revolution: How Lateral Power Is Transforming Energy, the Economy, and the World. Palgrave Macmillan.

RRI (Research Network on Innovation), 2014. Principes d'économie de l'innovation. Peter Lang, Brussels.

Schumpeter J., 1934. The theory of economic development: an inquiry into profits, capital, credit, interest, and the business cycle. New Brunswick, New Jersey: Transaction Books. (Translated from the 1911 original German, Theorie der wirtschaftlichen Entwicklung.)

Stiglitz J.E., Greenwald B., 2014. Creating a Learning Society: A New Approach to Growth, Development, and Social Progress. Columbia University Press, New York. 680 p.

Temple L., Barret D., Blundo Canto G., Dabat M.H., Devaux-Spatarakis A., Faure G., Hainzelin E., Mathé S., Toillier A., Triomphe B., 2018. Assessing Impacts of Agricultural Research for Development: a systemic model focusing on outcomes. Research Evaluation, rvy005, 1-14, doi:10.1093/reseval/rvy005 주

Thompson J., Scoones I., 1994. Challenging the Populist Perspective: Rural People's Knowledge, Agricultural Research, and Extension Practice. 
Agriculture and Human Values, 11, 58-76.

Touzard J.-M., Temple L., Faure G., Triomphe B., 2014. Systèmes d'innovation et communautés de connaissances dans le secteur agricole et agroalimentaire. Innovations - Revue d'économie et de management de l'innovation, 43, 13-38.

Von Hippel E., 2005. Democratizing Innovation. The MIT Press, Cambridge, MA.

1Top-down innovation is one that is proposed and promoted by some actors (for example, the research community) for the benefit of other actors (farmers, for example). It contrasts with bottom-up innovation, developed by the actors for their own benefit (farmers, for example) and who seek support elsewhere for it.

2The living lab is both a methodology and a place where citizens, inhabitants and users are considered as key actors in research and innovation processes.

3Innovations Studies, largely influenced by economists, analyse innovation at different scales (local or national), with a particular focus on innovation systems. Science and Technology Studies, promoted mainly by sociologists, explore the relationships between scientific research and society to produce technological innovations.

4The 'Innovation and Development' joint research unit, created in the mid-2000s, brings together some 90 researchers, research scholars and $\mathrm{PhD}$ students from the French Agricultural Research Centre for International Development (CIRAD), the National Institute of Agricultural Research (INRA) and the National Institute of Higher Education in Agricultural Sciences of Montpellier (Montpellier SupAgro). The research conducted in the unit is of a multidisciplinary nature (agriculture, economics, sociology, geography, management sciences, law). The unit's work is spread across the globe (southern Europe, Africa, southeast Asia, Latin America). 


\title{
Part 1
}

\section{Renewing agricultural approaches}

\section{Chapter 1}

\section{A history of innovation and its uses in agriculture}

\author{
Ludovic Temple, Yuna Chiffoleau and Jean-Marc \\ TOUZARD
}

Summary. Even though studies on innovation in agriculture are relatively new, they form part of a longer history of approaches to technical progress and transformations of the agricultural sector. This chapter explores the history of the uses of the notion of innovation in agriculture and reviews the studies in this field, focusing in particular on the contributions of economics and sociology. This history can be divided into three distinct periods: until the Second World War, the notion of innovation did not appear in the literature, even though the subject of technical progress, not included by economists in their analyses, was very present in the agricultural sciences; over the next 40 years, diffusionist approaches to innovation were applied to all sectors, including agriculture, whose modernization was supported by sociologists and economists; finally, starting in the 1980s, criticism started growing of this previous agricultural development model and was accompanied by a new way of thinking about innovation, opening up new perspectives for research on innovation in agriculture and related domains.

The origin and the first uses of the term 'innovation' had nothing to do with agriculture. Nor did it have a positive or technological connotation, as it does today (Godin, 2015). This term was first used in the legal and political fields, with a subversive and negative connotation in the 17th and 18th centuries, a connotation that persisted into part of the 19th century. For example, in 1740, 
in the French Academy's dictionary, innovation was defined as the 'introduction of some novelty into a custom, into a use, into an act'. It further urged that there is 'no need to innovate' because 'innovations are dangerous'. In this context, in which innovation was associated with a disruption of the established order, the first philosophers and economists who were interested in the transformations of agriculture and industry preferred to use the terms 'improvement' or 'progress' when studying technical domains or organization of labour. Such was notably the case of Smith and of Ricardo, and later of Marx, who believed technical progress to be one of the engines of economic development, or of Say, who associated it with entrepreneurship (Diemer and Laperche, 2014). It was only during the 20th century that innovation acquired a positive connotation, describing a process that generates technical or organizational changes, or in products or their uses. Innovation then became a field of research, at the interface of different scientific communities (economics, sociology, geography, management, etc.) and in multiple empirical domains, including agriculture and food. It even becomes an ideology that is inviting some criticism today (Godin and Vinck, 2017).

In this chapter, we explore how the notions of improvement and technical progress, and subsequently of innovation, have been applied and enriched by various authors, following different currents of economics and sociology, who have studied the transformations of the agricultural and food sectors. This historical approach analyses the evolution of these notions in these sectors, with respect to three factors:

- the influence of the general progression of ideas and theories on change and innovation, especially in economics and sociology;

- the macro-economic and social developments that help create the context of the challenges facing society regarding agricultural and agrifood activities; - the transformations of agricultural and food systems that can also influence the representations, questions and methods of those who analyse them.

We will then develop the idea that while the use of the notion of progress, and subsequently of innovation, in agriculture and food has been largely influenced by exogenous factors (general evolution of thinking on technical change, macro-economic and institutional contexts), the sector is also home to innovations whose analysis and debates enrich the more general work on 
this notion (Figure 1.1).

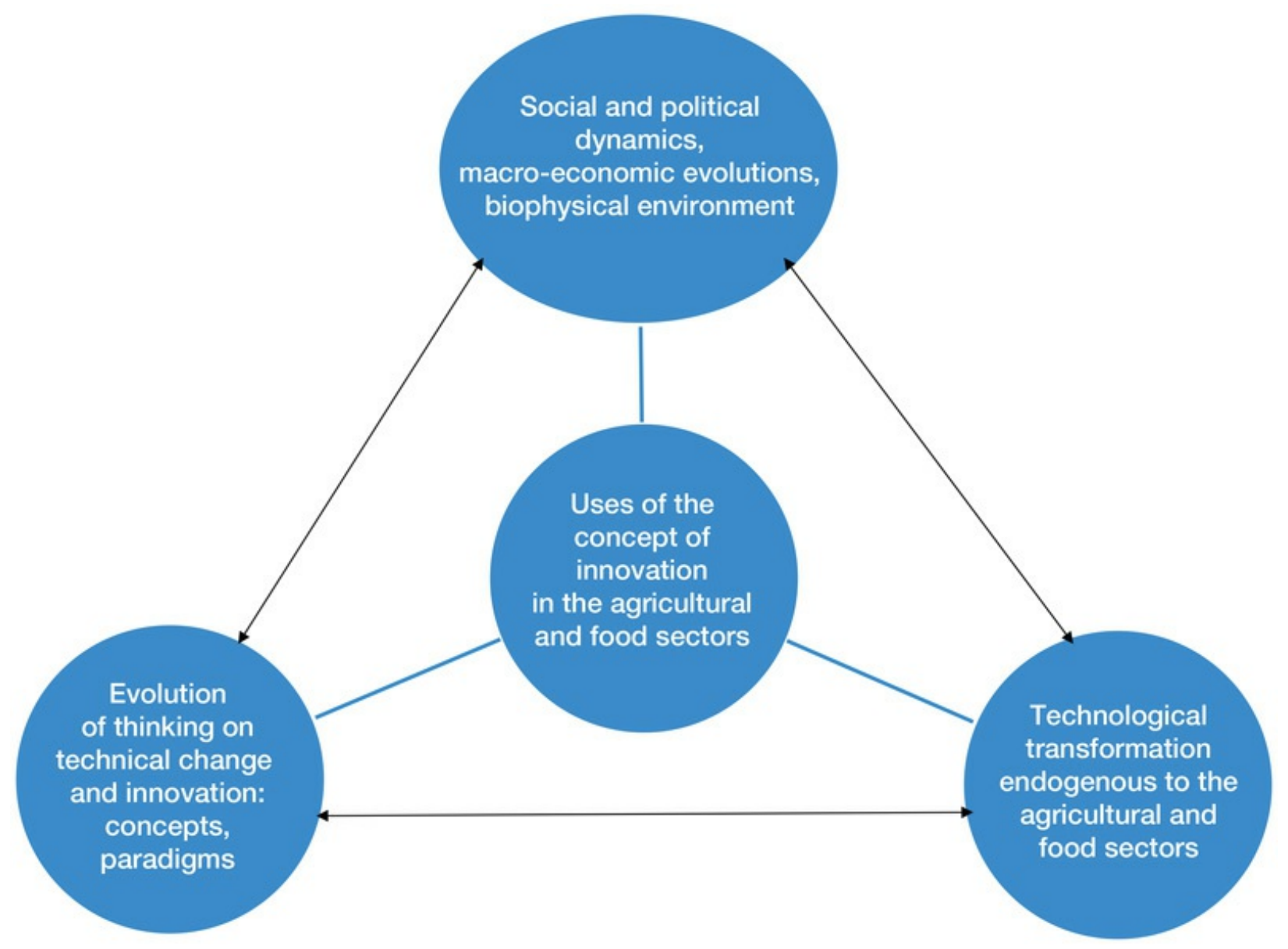

Figure 1.1. Analytical grid of innovation in agriculture.

This chapter bases itself first on a bibliographic exploration in economics and sociology, disciplines that were the first to focus on the notion of innovation in agriculture. It also relies on the work carried out by researchers of the Innovation joint research unit in France, who can be considered both witnesses to as well as actors of the uses of this notion. We have structured this chapter chronologically, distinguishing three major periods in the history of agricultural transformations and the use of the notion of innovation in agriculture. The first period covers the two centuries leading up the Second World War and the independence of many colonized countries. During this period, the notion of innovation was not used explicitly. The topic of technical progress was, at the same time, progressively excluded by academic economists in their analyses but was affirmed by scientists of the agricultural sciences. The second period covers the 30 to 40 years after the Second World 
War, during which the notion of innovation, promoted by Schumpeter (1934), was mobilized in all sectors, especially in agriculture, whose modernization was supported by sociologists and economists. Starting in the 1980s, the third period was marked both by growing criticism of this previous agricultural development model and by a new way of thinking about innovation - even going as far as to criticize the notion - in economics as well as in sociology. It is opening up new perspectives on the use of the notion of innovation in agriculture.

\section{W Two centuries of agricultural revolutions without any reference to innovation}

\section{The gradual transformation of agriculture at the time of industrialization}

European societies in the 18th and 19th centuries still suffered from food shortages (at least until the 1850s) that challenged the effectiveness of the institutions that governed agriculture, revealed the limitations of existing techniques, and called for progress in food production and distribution. Across Europe, the period was marked by the emergence of industry, profound political changes (including the French Revolution), an increase in scientific knowledge, population and urban growth, etc. Technical changes brought about a slow agricultural revolution, differentiated according to regions and sectors, closely linked to the growth of industry and trade (Vanderpotten, 2001). A major technical change in European agriculture was the abandonment of fallowing, replaced by the cultivation of forage and legume crops[5] (Griffon, 2017), thus reducing the need for arable land to meet food needs. The changes also concerned many other aspects: tools (ploughs, scythes, etc.), application of lime and fertilizer, drainage and irrigation, selective breeding of livestock, new crops and rotations, mechanization and motorization (threshing machines, traction engines, followed by tractors). Although mechanization of labour began in the 1850s, tractors started to be used for ploughing only much later because of the fragmentation of farms, a situation not conducive to the substitution of labour 
by capital.

All of these technical changes took place on the back of advances in knowledge about plant functioning and soil fertility. Agronomic research emerged during this period from the empirical outcomes of experiments undertaken by major landowners, and was subsequently carried forward by public action (Jas, 2005). These changes were mainly driven by developments exogenous to agriculture, such as the modification of the conditions of access to the commons (land), the growing demand for food, in cities as well in the countryside, the mobilization of fossil energy (coal) and of the steel and chemical industries, the growth of land and sea transport, and the expansion of international trade (Losch, 2015) This process spanned several centuries, with specific geographical variations. It was concurrent with the beginning of industry, which gradually absorbed the workforce no longer required by agriculture and which, in return, provided new technical objects for transport, mechanization and, progressively, fertilization and crop protection. The desire to increase the productivity of agricultural labour through scientific and technical progress kept growing.

The economic exploitation of colonial territories accelerated the industrial capitalism of European countries and allowed them to appropriate new commodities (cotton, rubber) and food resources, such as sugar or coffee, at low cost. The period of colonization can also be viewed as one in which a mode of production that 'optimized' the exploitation of natural resources and human resources (forced labour and slavery) was transferred through war to other territories. A technological trajectory based on a given mode of production, especially the implementation of the model of large plantations (rubber, sugar, banana, etc.) was imposed through coercion. Colonial agriculture partly funded the capital investments that accelerated the industrialization of Western countries. In 1791, for example, the main export earnings of the French Republic were from commodities, including coffee, sugar, and cotton (Jaurès and Soboul, 1983). They financed the food (cereal) imports necessary to secure social peace in the nascent industrial, textile and mining sectors.

\section{From physiocrats to neoclassicals: the first}




\section{economists progressively excluded agricultural technical change from their analyses}

These two centuries of transformation of agriculture were observed by the first economists and sometimes inspired their vision of technical progress. This was the case, in the 18th century, of physiocrats in France (led by Quesnay) who argued that investments by rich farmers, enlightened by new methods, would lead to improvements in agricultural efficiency and therefore to the creation of national wealth. Classical economists (Smith, Ricardo, Mill, Say, and others) would subsequently focus on technical change, but mainly as it concerned nascent industry - even though agriculture figured in their work (Boutillier and Laperche, 2016). For Smith, the introduction of new machines and the division of labour were the result of initiatives by economic actors (especially craftsmen), but he also believed that profound institutional and contractual changes, to which technical innovations were subordinated, were also responsible (Labini, 2007). In agriculture, he suggested, for example, establishment of long-term farming contracts to encourage investment. For his part, Ricardo (1817) identified two forms of improvement in agriculture, namely those that 'increase the productive capacity of the land' (new rotations, fertilizers, etc.) and those that 'by the perfection of the machines make it possible to obtain the same product for less labour' (the plough, the beginning of mechanization). Say compared the farmer, already dear to the physiocrats, to an entrepreneur in the agricultural industry and insisted on the links between the technical changes in agriculture and those in industry, because 'the use of machines frees men from food production, allowing them to devote themselves to other activities' (Say, quoted by Boutillier, 2004). He himself invested in the first French cotton spinning mills which used cotton imported from the colonies, illustrating how industrial progress, too, was driven by colonial agriculture. But classical economists did little to explain the conditions that were conducive to technological change and its links to scientific progress. While they noted the consequences of technical progress in agriculture, they underestimated the innovative capacities of agrarian societies, thus providing fodder to Malthusian theses which argued that famines and wars were the elements that reduced the disparity between demographic pressure and agricultural production.

Continuing this work in a critical way, Marx placed technical progress in a 
historical perspective, inscribing it in the dynamics of capitalism and the evolution of social relationships. According to him, this entailed 'an appropriation of living labour by capital', violent for the workers and the peasants, but which appeared necessary for humanity's progress (Marx, 1959). Kaustky (1900) developed this analysis in agriculture, arguing that the rise of the 'mechanical, chemical and biological sciences' led to its industrialization, and favoured large farms and the proletarianization of the peasantry. This thesis was challenged in Russia by Chayanov in the 1920s, but it was only starting in the 1960s that his ideas concerning the ability of peasant agriculture to adopt technical change found favour in the wider scientific community.

For their part, neoclassical economists (Marshall, Walras, Menger, etc.), who asserted themselves in the late 19th century and towered over the field in the 20th century, did not include technical change in their analyses. Even though it was promoted in the rhetoric, technical change was considered a variable exogenous to economic analysis, which had to limit its focus to the balances between and decisions of rational agents coordinated by the market. Technical change then became a possible cause, unstudied, of the change of the function of production of an enterprise, including of an agricultural enterprise. But since it was difficult to measure, it was not incorporated into this function of production. More oriented towards the analysis of the sectors of industry, commerce and business, or towards the construction of mathematical models, academic economists at the beginning of the 20th century ended up by no longer bothering about technical progress, especially in agriculture.

\section{The analysis of technical change in the agricultural sciences}

Although the issue of technical change in agriculture was ignored for the most part by the academic economists of the 19th century, it was, on the other hand, very present in the analyses of the first chemists, agronomists, rural economists, and historians who taught and worked in agricultural schools (Mazoyer and Rondart, 1997), were active in agrarian circles or belonged to learned societies in France, Great Britain, Germany or Russia 
(Robin et al., 2007). Their vision was very pragmatic and positive, and was stamped with the conviction that rationality and science would lead to the development and growth of a modern agriculture (de Lavergne, 1860). This was the beginning of the agricultural sciences, based not only on observations, travel, historical studies, teachings, experiments at field stations and in laboratories, but also on many regional publications and on agricultural fairs (Jas, 2005). The technical progress resulting from the 'alliance of science and art in cultivation of the soil' (Grandeau, 1869, quoted by Jas, 2005) formed the core of this work and was embodied in journal titles, such as Progrès agricole et viticole (Agricultural and Viticultural Progress), published in Montpellier from 1884. There were debates also on the use of the very notion of innovation, which remained ambivalent and suspect, as explained by the chairman of the agricultural fair of Chartres in 1856 (quoted by Farcy, 1983): 'Improvement and innovation! These words express two very different ideas, which is why I have great reluctance in accepting certain new machines, so extolled by some that others display completely justifiable misgivings. [...] The earth is not cultivated using a pastry-cutter approach, and some combinations, very ingenious in theory, are more admired unused, at the Centre for Arts and Crafts [in Paris], than they would be in the field, where they would have to confront unexpected obstacles.'

The analysis of technical changes was also the focus of studies that paved the way for the first rural sociologists in the early 20th century. Authors such as Weber (1904), Augé-Laribé (1905) and Bloch (1931) analysed the social and political conditions which governed the technical transformations in European agriculture (especially in France and Germany). According to these authors, technical progress in agriculture resulted from a willingness to assess and increase labour productivity. These efforts were undertaken by different categories of actors depending on the country or region (Junker, farmer, sharecropper, winemaker, etc.), all of whom had to contend with the weight of inherited traditions and entrenched social structures. This first sociology of technical change in agriculture also highlighted the many factors that influenced it, such as the dissemination of scientific progress via industry and education, the expansion of the market for products and inputs, institutional and political changes, and changing social needs resulting from the development of an industrial society. 
It can be seen from these studies that agricultural transformations were not driven by violent disruptions in technical systems. Technical changes occurred gradually depending on economic, scientific, social and political movements. The term 'agricultural revolution' is therefore far from appropriate to describe this period. The true technological and industrial shift in agriculture happened mainly after the end of the Second World War.

\section{Wreen revolutions driven by the linear and technological conception of innovation}

\section{Modernization and green revolution of agriculture during the Thirty Glorious Years[6]}

The post-Second World War context created an institutional environment that placed the State at the centre of productive investments in order to quickly rebuild the foundations of global food production. Following two world wars, rural areas in Europe had become depopulated. It was a matter of ensuring food security rapidly, in light of population growth and the political risks posed by food crises. A major aspect of this reconstruction was the rapid use of technological advances generated by military investments in the war effort. Chemical work on poison gases, begun during the First World War, contributed to rapid advances in synthesizing ammonia to produce massmarket chemical fertilizers after the Second World War (Allaire and Daviron, 2017). The work on military tanks (motorization, caterpillars) led, in a few years, to the mechanization of ploughing in European agriculture. This transformation of agriculture in the industrial countries was all the more rapid since the post-war reconstruction effort increased the cost of salaried labour and forced the search for a rapid increase in agricultural labour productivity. Industry-developed models were soon applied to agriculture and activities of food processing and distribution in the quest for specialization, economies of scale and the dissemination of technological innovation. The mass consumer society in Europe and the United States could come into being only because of the many process and product innovations undertaken by companies, which would soon collectively constitute a real agrifood industrial sector 
based around milk, cereals, oilseeds, and meat, whose production was sought to be strengthened at national scales (Malassis, 1979).

The State's pre-eminent role expressed itself through the drafting and adoption of ambitious agricultural policies, which intervened at several levels and across domains, to accompany agricultural modernization: protection of markets, subsidized credit, investment in infrastructure, teaching, extension, and agronomic research. In France, this policy was based on an approach of co-management with agricultural organizations in order to promote a modernized family-farm business model (Coulomb et al., 1990). A little later, Western countries set up international centres for agricultural research (Gerard and Marty, 1995)[7] in a context not only of decolonization but also of the fight to prevent the expansion of communism. This effort was also driven, in part, by popular discontent stemming from worsening poverty and food insecurity in so-called 'third world' countries. The goal of this international agricultural research effort was to increase global food production by mobilizing new green-revolution technologies, especially by growing new high-yield cereal varieties. These varieties, developed at experimental field stations, required an intensification of production systems through the use of synthetic fertilizers and pesticides. The newly independent countries that emerged from the process of decolonization also implemented favourable agricultural policies (agricultural price support, input subsidies, etc.) and created extension structures, in the words of their leaders, to train the farmers to adopt the new technologies. This technological model, supported in the 1970s and 1980s by international funding and development bodies, oriented agricultural research in developing countries towards experimentation in order to ensure the successful transfer of inventions mainly developed by the research community and industry in developed countries (Lele and Goldsmith, 1989; Raina, 2011).

This model of technical intensification of agriculture, based on the consumption of chemical inputs and fossil energy, involves significant financial investments in agriculture, which are more feasible in industrial and emerging countries (China, India, Brazil, etc.) than in developing ones. It performs well in terms of the objectives of increasing productivity in contexts where the process of production is relatively secure (reduced natural and economic risks). Its implementation in these contexts leads to the adaptation 
of agriculture to the requirements of industrial processing. In contrast, in contexts of low industrialization, unorganized markets, high rural densities, elevated climatic risks, low access to financing or a weak State, this model's effectiveness is much more debatable. This is especially the case in many countries in Africa and Asia, where small family farming dominates and where farmers are unable finance the purchase of inputs and equipment but cannot find work either in the industrial sector (Dorin, 2017)[8].

\section{The economics of innovation: from Schumpeter to industrial economists}

These rapid transformations of national economies and their agriculture can be analysed on the basis of research that emphasizes the notion of innovation, with, at the forefront, the work of Schumpeter (1934). He studied how the great technological transformations (steam engine, electrical energy) punctuated economic cycles with phases of 'creative destruction'. A driver of this trend was the concentration of companies, belonging to many different industrial sectors, both upstream (agro-chemical industries) as well as downstream (agrifood industries), into oligopolistic markets. Innovation appeared as a strategic objective of firms, the 'weapon of oligopolistic competition replacing that of prices', and a means for perpetuating capitalism. Schumpeter noted the distinction, still valid today, between invention and innovation, by considering the entrepreneur as the central actor who combines the new technology (the invention) with the market to produce an innovation. He proposed a first typology of innovations, according to the type of the novelty concerned (product, process, raw material, market, or organization).

Several studies, including those of Schumpeter, inspired the design of the linear model of innovation and post-war public policies, which was soon extended to agriculture. Thus industrial economics research in the post-war years legitimized both public policies and the central role of the State in defining major technological choices through public procurement and large enterprises, mainly in the infrastructure and energy sectors. In the late 1970s, neoclassical economists, in turn, accepted the idea of an endogenous dynamic of technological change by introducing the role of human capital in the 
mechanisms of growth (Denison, 1962). This shift soon led to the replacement of the term 'technique' in the literature by 'technology'.

\section{Social sciences at the service of agricultural modernization}

During these 'Thirty Glorious Years' of strong economic growth following the Second World War, many social scientists studied and supported technical changes in agriculture, gradually using the notion of innovation, seen above all as the adoption by farmers of new technical objects (seeds, fertilizers, pesticides, machinery, etc.) developed by the research community and industry. The disciplines of rural sociology and economics in the postwar years, first in the United States then in Europe, thus committed themselves largely to the cause of agricultural modernization (Ruttan, 1996) and the transfer of this model of development to countries of the Global South (Badouin, 1985).

Rural sociology, to begin with in the United States (Rogers, 1976), would thus provide, for more than 30 years, the analytical tools and methods to promote the dissemination of new technologies by studying obstacles to their adoption and by proposing a categorization of adopters (innovators, early adopters, followers, etc.) that is still in use today in the literature on innovation. In France, sociologists also relied on the notion of innovation to analyse obstacles to agricultural modernization and the conditions that were conducive to it, which depended on the social structures of rural societies (Mendras, 1970), the modes of engagement in collective action (Boisseau, 1982), the evolution of mechanisms of intervention (training, credit, advice, etc.) and on organizations (unions, farmers' associations, cooperatives, etc.) driving progress in the countryside (Bodiguel, 1975).

Influenced by the evolution of the micro-economics, rural economists, on the one hand, created management tools for a modern and organized agricultural enterprise open to innovation (Chombart de Lauwe, 1949), and, on the other, mobilized econometric models to assess or account for the effects of technical change (Boussard, 1987). The farmer was thus supposed to make innovation choices as an agent optimizing an income function. These models 
were used for two important purposes. The first was to orient ex ante technical research in experimental stations towards solutions for maximizing economic performance. The second was to model the functioning of markets in order to understand the relationships between production factor prices, product prices and the adoption of technologies in order to support the implementation of favourable agricultural policies. Economic studies on technical change were also undertaken in developing countries, in particular to measure the gaps between real productivity and potential productivity, which varied by region, and to explain the determinants of technical change. These studies generally pointed to constraints in farmers' access to inputs, capital and knowledge produced by agronomic research. Starting in the late 1970 s, other studies sought to understand the rationales and practices of farmers in order to adapt the technical proposals made to them by R\&D organizations (Jouve and Mercoiret, 1987).

Innovation also attracted a critical appraisal, inspired by Marxism, by rural economists and sociologists in several countries (Coulomb et al., 1990), but their analyses focused more on the evolution of labour relationships and agrarian structures than on innovation itself. Innovation was generally seen as a means for spreading capitalism, in the countries of the Global North as well as those in the Global South, or for the quasi-integration of agriculture into industrial sectors.

During the Thirty Glorious Years, the notion of innovation thus spread in the scientific communities that progressively came to constitute the disciplines of rural and agricultural economics and sociology, which accompanied and supported agricultural modernization in the Global North and in the Global South. Coupled with a fairly consensual view of progress and development in agriculture (and also in the food sector), studies on innovation referred to Schumpeter (more cited however in research on industrial sectors) and were marked by a diffusionist and pragmatic vision, in line with the development challenges of modern and postcolonial societies.

\section{A fresh look at the notion of innovation in the face of agricultural and food transitions}




\section{From the crisis of the productivist model to new approaches to innovation}

The development model of the Thirty Glorious Years began to be called into question as early as in the late 1960s, marking the emergence of a search by consumers and citizens for goods of differentiated quality. The cultural crisis asserted itself in the 1970s, driven by social movements that questioned the productivist model and the willingness to let corporate interests dictate lifestyles of entire populations (Touraine, 1978). A new societal model was sought to be built around issues concerning the environment, identity, autonomy, and self-management practices. This cultural crisis was concurrent with repeated and increasingly intense economic crises that occurred as early as the 1980s and that would culminate in the financial crisis of 2008. This succession of crises has to be seen in the context of the very many environmental and social externalities of the economic growth model of the Thirty Glorious Years that was based on industrialization and global expansion of firms: accelerated depletion of stocks of natural resources (fossil fuels, water reserves, phosphates), biodiversity erosion, climate change, structural increase in social inequalities, and health and environmental crises linked to the use of synthetic inputs. Agricultural and food issues began gaining an increasing importance in these condemnations and in political debates about the planet's evolution and the innovations likely to help meet global challenges (see Chapter 2). The reorientation of agricultural policies in the United States, and especially in Europe, starting in the late 1980s, largely reflects these concerns, as does the change in the tenor of debates in international institutions and in their development goals (McIntyre et al., 2009). At the same time, the assertion of new forms of agrarian capitalism, especially in South America and Southeast Asia, not only allowed the continuation of the agro-industrial model, but also strengthened its criticism, particularly from peasant and agroecology movements (Allaire and Daviron, 2017). The difficulties of the technological transposition of the Green Revolution to Africa also showed that the industrialization of agriculture cannot be exported to the entire world and that other ways of development would have to be found. Thus, the work of development economists in contexts of pressure on natural resources and demographic pressure emphasized the innovative capacities of agrarian societies that derived value from the productive potential of their ecosystems (Boserup, 1981). 
More broadly, the crises that societies have been experiencing, especially since the 1980s, have forced companies to revamp their growth models. On the one hand, they are now being encouraged to take into account the social conditions of innovation (internally and in their environment) and, on the other, they are being called upon to invest, beyond or alongside technological innovations, in organizational innovations and intangible investments in order to become part of the new economies of quality, knowledge and services (Gadrey, 1992; Cohendet et al., 1998). Agribusiness companies illustrate this trend (Rastoin, 2000). In this context, agronomic research is now including new approaches to innovation. In France, at the National Institute of Agricultural Research (INRA), this trend was embodied in particular in the multidisciplinary and participatory work of its 'Agrarian Systems and Development' (SAD) department, set up in 1979 (Cornu et al., 2017). In tropical countries, it is being reflected, in particular, in the increasing use of the term 'agroecology', mobilized initially to characterize food crop production systems (Altieri, 1995; Caplat, 2012). This notion was also used in research studies in the mid-2000s as a basis for the concepts of sustainable[9] or ecological intensification and to propose other ways of intensification in situations with degrading resources (Griffon, 2006). Agricultural research policies and institutions in some countries (France and Brazil, for example) would go on to use this notion more widely to encourage an improved compliance of agriculture with ecological principles.

During this period, the diffusionist paradigm of innovation was thus discarded or reconfigured, opening the way to a diversity of approaches to innovation in the entire production system (industry, agriculture, services) and in the construction of new links between agriculture and food and/or between agriculture and the environment.

\section{The increase in research on innovation in economics}

Economists have reacted to these social upheavals by increasing the amount of research on innovation. No doubt, many authors still continue to approach innovation as a part or an extension of neoclassical economics, not as a 
process but as a (new) factor of production for the firm, associated with investments in research and development, and tradable on a market in which technologies are protected by patents. But the diffusionist paradigm was called into question in the 1980s by other economists, who propose instead an evolutionist approach to innovation (Nelson and Winter, 2002; Dosi, 1993). By making analogies with biology, they emphasize how economic decision models are adaptive. Thus, the adoption of a technology is seen as the result of a gradual process, based on interactions internal and external to the company, which culminates in a selection of the most appropriate innovations. The economic problem lies in the definition and implementation of the firms' capabilities, procedures and decision-making rules to innovate and change their routines. Evolutionary economics is thus built not only around concepts of routine and innovation, but also around technological paradigms and path dependence[10]. This evolutionary approach has become so dominant in the economics of innovation and technical change that it has led to a new focus of the research community, on 'Innovation Studies' (Martin, 2012). In this framework, innovation processes are also analysed through the concept of the innovation system, which allows the business strategies, institutions, networks and knowledge dynamics that determine and condition innovation at a national, regional or sectoral level to be studied together (Spielman, 2006).

By helping determine the conditions conducive to innovation and the effects of its various categories, the notion of innovation also began to be used in economic currents other than Innovation Studies:

- research on industrial districts (Becattini, 2004), localized production systems, clusters and innovative environments thus highlighted the importance of local interactions and proximity (Pecqueur and Zimmerman, 2004);

- research on the neo-institutional economy also analysed the modes of governance of innovation and associated contracts and patents (Guellec, 2009);

- other economists, specializing in political economics, followed in Schumpeter's footsteps by showing how innovation is linked to the crises and transitions of capitalism (Boyer, 2015);

- financial economics itself views innovation as a process, proposing 'financial innovations' to support it. 


\section{Diversity of uses of the notion of innovation in agricultural and rural economics}

This large body of work on innovation in economics, dominated by the evolutionary influence, is reflected in the increasing number of articles and books that use this notion of innovation to address agricultural and/or food issues. We can mention at least three types of uses (Touzard et al., 2014).

First, the agriculture and agrifood sector can be considered simply as one of several empirical domains in which academic frameworks, such as evolutionary or neo-institutionalist analysis, can be used to analyse innovation. This is the case in many academic studies concerning the development of national innovation strategies or the analysis of the emergence of a new food product or biotechnology. These visions are sometimes still close to diffusionist theses, according a key role to the research community and to the evaluation of the conditions that are conducive to the acceptability of innovations by farmers and society.

Other studies, in political economics, analyse the processes of agricultural and food innovations with a more critical and historical approach, linking them to the transformations of the sector and its relationships with the rest of the economy and society (Allaire and Daviron, 2017). The issue of the sector's specificity, its institutions and its innovations then arises, which can in return inform academic and political debates.

Finally, it is important to note the existence of analyses, often related to development actions in agriculture, which advocate more original approaches to innovation by highlighting the sector's specificities and by defending a more operational perspective of rural and agricultural economics. Innovations are associated with the particular functioning of farms, the management of externalities and local resources (land, water, landscapes, etc.), links with tourism or food supply, etc. For example, innovations pertaining to products whose quality is linked to their local origins call for approaches specific to localized agrifood systems. Similarly, the analysis of the sectoral conditions of innovation leads to the use of specific concepts such as Agricultural Innovation Systems, which urge both the Global North and the Global South to revamp the diffusionist model and reorganize agricultural research and 
advisory structures (Sumberg et al., 2002; Temple and Compaoré Sawadogo, 2018) or which propose the inclusion of specific provisions for supporting innovation in agricultural policies.

\section{Studies on the social dynamics of innovation in agriculture}

Starting in the 1970s, the break with the diffusionist model of innovation in agriculture helped to structure several research communities in sociology. By reconnecting agriculture to the domains that innovation impacts or that constrain it (environment and food, in particular), sociology also opened up spaces of new collaborations with economics.

First, a series of studies starting in the 1970s illustrated a new approach to agriculture and the rural world, relying on popular knowledge, albeit with the risk of ideological populism. The work of Chambers et al. (1989), in particular, paved the way for studies rehabilitating local empirical knowledge and endogenous innovation. A major contributor to a renewal of social science research in the agricultural sector in France in the 1980s, Darré was part of this perspective. He shifted the analysis from being based on categories (researchers, farmers, etc.) to local configurations of actors (morphology of networks), more or less conducive to the collective capacities of innovation (Darré et al., 1989). This shift was accompanied by the realization that one of the sources of innovation in agriculture is the fact that certain farmers belong to several social groups (multi-belonging). This result was consistent with research in the socio-anthropology of development conducted in the Global South (de Sardan, 1995).

Other research studies, also in the socio-anthropology of development, opened up another perspective by bringing back into the analysis of innovations the historical trajectory and institutional context that surround the technical and organizational changes, from macro-economic policies to micro-economic decisions of enterprises (Chauveau et al., 1999; RequierDesjardins, 1999). This approach thus encourages exploration of how technical changes in agriculture can take different historical trajectories depending on national and local contexts. 
Research into alternatives to the productivist model, both in the countries of the Global North as in those of the Global South, also encouraged another field of study that adopted a more dissenting perspective. Thus, the sociology of social movements found fertile ground, basing itself in particular on environmental initiatives. These initiatives denounced the environmental damage caused by technical progress and were analysed as building a new social movement, namely an action (and no longer a situation or category, such as a social class) aimed at transforming society, not only through protest but also through local, concrete and innovative alternatives (Touraine, 1978). These new social movements (ecology, feminism, regionalism, etc.) and associated initiatives, especially in the field of local development, helped bring out the notion of social innovation. Social innovation thus designates new innovation goals and rationales. Linked with agriculture, it took shape mainly through studies on alternative food supply chains and other local dynamics that reconnect agriculture and food in a perspective of sustainability (Seyfang and Smith, 2007). In these studies, and more generally, social innovation has been closely linked to a second notion, that of civil society, which highlights the need to take new actors of social change into account (Laville, 2014).

These initiatives have also been of interest to other practitioners and theorists of innovation, working in disciplines ranging from the sociology of innovation[11] to 'science and technology studies', who saw the opportunity to propose an alternative to the centralized model of technological innovation in the form of a distributed innovation model, open to a greater diversity of actors, non-human agents, mechanisms and novelties (Von Hippel, 2005; Joly et al., 2010). Research conducted in this perspective has shown how markets and associated technologies generate focal issues of concern that lead to the emergence of 'concerned groups' and new socio-technical networks (Callon, 1986). These groups and networks help invent and disseminate both organizational as well as technological solutions to the identified problems.

In the agricultural sector, this emergence is contributing to the development of a new regime of production of knowledge and innovation concerning the living world. This new regime has been put into perspective, for example, through the long history of varietal innovation in France (Bonneuil and Thomas, 2009), shaken up by movements that reject genetically modified 
organisms and advocate instead for the use of farmer seeds. Analyses of the role played by local groups in the evolution of technical systems and by social structures at higher organizational levels (sectors, public policies, etc.) both inform and call into question research clubbed under the heading of 'theories of transition' (Lamine, 2012). This type of analysis is inspired by the sociology of innovation, science and technology studies, and evolutionary economics (Geels and Schott, 2007).

Finally, the analysis of innovation in the agricultural sector, or in connection with this sector, generates new collaborations between economists and sociologists around how the roles of institutions, networks and knowledge should be taken into account. These collaborations highlight the importance of institutional and local contexts in the emergence of initiatives, especially in the case of social innovations that pertain to sustainable food production and/or local development (Chiffoleau and Prévost, 2012; Laville, 2014). They allow to deepen the analysis of the learning and coordination processes, within networks of agricultural and agrifood actors, that underpin changes in practices and the co-production of new rules and norms (Chiffoleau and Touzard, 2014). In this way, these collaborations participate in the renewal of research on innovative environments and local productive systems.

\section{Conclusion: innovation in agriculture, a source of theoretical evolutions and interdisciplinarity}

In this chapter, we used a historical reading to present how economics and sociology were used to analyse technical change and innovation, first in the agricultural sector and then, more recently, in the agrifood and food sectors as also in territorial development. We have shown how the thinking in these two disciplines has shifted from technical progress to different forms and acceptations of innovation by examining the transformations of agriculture, with periods during which there were divergences or convergences of ideas, of application or reformulation of approaches and issues. The influences specific to the history of these disciplines have been significant, with, for example, the distancing of neoclassical economics from the questions of technical change, followed by the reinvestment of this discipline around the contributions of Schumpeter. Nevertheless, because work on the ground has 
become inseparable from development issues, the agricultural sciences, followed by rural economics and sociology, have also in some cases contributed to changing the conceptual frameworks for analysing innovation, both in economics and sociology. The territorial anchoring of agrifood innovation, the importance of debates and controversies concerning modifications of the living world or food security, the agroecological transition, and the emergence of social innovations in food systems are important examples of the wide range of possible research today on innovation and are potentially sources of generic results for economics and sociology.

This review has also shown that the function of innovation in agricultural development processes has varied over time, depending on socio-historical contexts and societal demands that have influenced the content. In the postwar years, marked by the recourse to concepts developed by Schumpeter, societal demand led to the transformation of agricultural activity to rapidly increase productivity. From the 1970s and 1980s, the crisis (social, cultural, then economic) that productivist agriculture contributed to led to a widening of the aims of innovation and to the involvement of a wider range of social actors (consumers, citizens, experts, etc.) in its genesis. This new context has not only called for a diversification of approaches to innovation, in both economics and sociology, but has also encouraged collaborations between these two disciplines in order to better apprehend the various factors and effects of change.

Putting the varied use of the notion of innovation in the agricultural sector in a historical perspective thus leads us to a stimulating exercise, in which the scientific research on transformations interacts with these same transformations. This effort is a new contribution to the common ground between economics and sociology. In this sense, innovation in the agricultural sector is also an intermediate object (Vinck, 1999); it permits the meeting between disciplines and the construction of interdisciplinarity. The challenge thus is to focus the debate between the disciplines more around innovation, going beyond just economics and sociology, by including and combining the sciences of management, geography and agronomy, which are already very present not only in the field of analysis of agricultural transformations but also in other domains, such as food and the environment, 
in particular.

\section{Wibliography}

Allaire G., Daviron B., 2017. Transformations agricoles et agroalimentaires. Entre écologie et capitalisme. Éditions Quæ, Versailles, 429 p.

Altieri M.A., 1995. Agroecology: The Science of Sustainable Agriculture, 2nd edition. Westview Press, Boulder.

Augé-Laribé M., 1905. Le rôle du capital dans la viticulture languedocienne. Revue d'économie politique, 193-222.

Badouin R., 1985. Le développement agricole en Afrique tropicale. Cujas, Paris, $320 \mathrm{p}$.

Becattini G., 2004. Industrial districts: A new approach to industrial change. Edward Elgar Publishing.

Bloch M., 1931. Les caractères originaux de l'histoire rurale française. Armand Colin, Paris.

Bodiguel M., 1975. Les paysans face au progrès. Les Presses de Sciences Po, Paris.

Boisseau P., 1982. Sources de l'innovation dans les exploitations agricoles. Inra, série Études et recherches.

Bonneuil C., Thomas F., 2009. Gènes, pouvoirs et profits. Recherche publique et régimes de production des savoirs de Mendel aux OGM. Éditions Quæ, Versailles.

Boserup E., 1981. Population and Technological Change: A Study of LongTerm Trends. The University of Chicago Press, Chicago.

Boussard J.M., 1987. Économie de l'agriculture. Édition Economica, Paris, $300 \mathrm{p}$. 
Boutillier S., 2004. Économie et économistes face à l'innovation. In: L'innovation et l'économie contemporaine : espaces cognitifs et territoriaux (D. Uzunidis, ed.). De Boeck, Louvain, 21-44.

Boutillier S., Laperche B., 2016. Christopher Freeman : la systémique de l'innovation. In: Les grand auteurs du management de l'innovation et de la créativité (Burger-Helmchen T., Hussler C., Cohendet P., eds). Éditions Management et Société, 38-57.

Boyer R., 2015. Économie politique des capitalismes. La découverte, Paris.

Callon M., 1986. Éléments pour une sociologie de la traduction. La domestication des coquilles Saint-Jacques dans la Baie de Saint-Brieuc. L'Année sociologique 36, 169-208.

Caplat J., 2012. L'agriculture biologique pour nourrir l'humanité. Actes Sud, $477 \mathrm{p}$.

Chambers R., Pacey A., Thrupp L. (eds), 1989. Farmer first. Farmer innovation and agricultural research. Intermediate Technology Publications, London.

Chauveau J.-P., Comier-Salem M.-C., Mollard E., 1999. L'innovation en agriculture: questions de méthodes et terrains d'observation. Édition IRD, $362 \mathrm{p}$.

Chiffoleau Y., Prévost B., 2012. Les circuits courts, des innovations sociales pour une alimentation durable dans les territoires. Norois, 224, 7-20.

Chiffoleau Y., Touzard J.-M., 2014. Understanding local agri-food systems through advice network analysis. Agriculture and Human Values, 31(1), 1932.

Chombart de Lauwe J., 1949. Pour une agriculture organisée. Presses universitaires de France, Paris.

Cohendet P., Foray D., Guellec D., Mairesse J., 1998. La gestion publique des externalités positives de recherche. Revue française de gestion, 128-138. 
Cornu P., Valceschini E., Maeght-Bournay O., 2017. L'histoire de l'INRA, entre science et politique. Éditions Quæ, Versailles.

Coulomb P., Delorme H., Hervieu B., Jollivet M., Lacombe P., 1990. Les agriculteurs et la politique. Presses de la Fondation de Sciences Politiques, Paris.

Darré J.-P., Leguen R., Lemery B., 1989. Changement technique et structure professionnelle locale en agriculture. Économie rurale, 192(1), 115-122.

Denison E., 1962. The sources of economic growth in the United States and the alternatives before us. Committee for Economic Development, New York.

Diemer A., Laperche B., 2014. De la critique des corporations à la libération des forces productives : l'économie politique de Jean-Baptiste Say. Innovations, 3, 19-38.

Dorin B., 2017. India and Africa in the Global Agricultural System (19602050): Towards a New Sociotechnical Regime?, Economic \& Political Weekly, LII (25-26), 5-13.

Dosi G., 1993. Technological paradigms and technological trajectories. Research Policy, 22(2), 102-103.

Farcy J.-C., 1983. Le monde rural face au changement technique : le cas de la Beauce au XIxème siècle. Histoire Économie et Société, 2, 161-184.

Gadrey J., 1992. L'économie des services. La Découverte, Paris.

Geels F.W., Schott J., 2007. Typology of sociotechnical transition pathways. Research Policy, 36(3), 399-417.

Gérard F., Marty I., 1995. Les politiques d'accompagnement de la révolution verte en Asie. Revue d'économie du développement, 2, 93-114.

Godin B., 2015. Innovation Contested - The Idea of Innovation Over the Centuries. Routledge, London. 
Godin B., Vinck D., 2017. Critical Studies of Innovation. Edward Elgar Publishing, $335 \mathrm{p}$.

Griffon M., 2006. Nourrir la planète pour une révolution doublement verte. Odile Jacob, Paris.

Griffon M., 2017. La nature comme modèle : un chemin vers l'appréhension de la complexité agricole. In: Evolutions agro-techniques contemporaines (Dubois M.J.F., Sauvée L., eds), Université technologique de BelfortMontbeliard.

Guellec D., 2009. Économie de l'innovation. La Découverte, Paris.

Jas N., 2005. Déqualifier le paysan, introniser l'agronome, France 18401914. Écologie et politique, 31, 45-55.

Jaurès, J., Soboul A., 1983. Histoire socialiste de la Révolution française, vol. 2. Éditions sociales.

Joly P.B., Rip A., Callon M., 2010. Reinventing innovation. In: Governance of Innovation. Firms, Clusters and Institutions in a Changing Setting (Arentsen M. J., van Rossum W., Steeng A. E., eds), Edward Elgar Publishing, pp.14.

Jouve P., Mercoiret M.R., 1987. La recherche-développement : une démarche pour mettre les recherches sur les systèmes de production au service du développement rural. Les Cahiers de Recherche-Développement, 16, 8-15.

Kautsky, K., 1900. La question agraire : étude sur les tendances de l'agriculture moderne. Éditions V. Giard et E. Brière, Paris.

Labini P., 2007. Développements scientifiques, innovations technologiques. croissance et productivité. Revue d'économie industrielle, 118, 79-90.

Lamine C., 2012. "Changer de système ": une analyse des transitions vers l'agriculture biologique à l'échelle des systèmes agri-alimentaires territoriaux. Terrains \& travaux, 20, 139-156.

Lavergne (de) L., 1860. L'économie rurale de la France depuis 1789. 
Librairie agricole, Paris.

Laville J.L., 2014. Innovation sociale, économie sociale et solidaire, entreprenariat social. Une perspective historique. In: L'innovation sociale (Klein J.L., Laville J.L., Moulaert F., eds), Eres, Paris.

Lele U., Goldsmith A., 1989. The Development of National Agricultural Research Capacity: India's Experience with the Rockefeller Foundation and Its Significance for Africa. Economic Development and Cultural Change, 37(2), 305-343.

Losch B., 2015. Family Farming: At the Core of the World's Agricultural History. In: Family Farming and the Worlds to Come (Sourrisseau J.-M, ed.), Springer Netherlands.

Malassis, L., 1979. Économie agro-alimentaire, vol. 1. Cujas, Paris.

Martin B., 2012. The evolution of science policy and innovation studies. Research Policy, 41, 1219-1239.

Marx K., 1959. Capital. Vol. II. Progress Publishers, Moscow.

Mazoyer M., Rondart L., 1997. Histoire des agricultures du monde : du néolithique à la crise contemporaine. Seuil, Paris.

McIntyre B., Herren H., Wakhungu J., Watson R. (eds), 2009. International Assessment of Agricultural Knowledge, Science and Technology for Development, Global report. Island Press, Washington, DC.

Mendras H., 1970. La fin des paysans : innovations et changement dans l'agriculture française. Colin, Paris.

Nelson R., Winter S., 2002. Evolutionary theorizing in economics. Journal of Economic Perspectives, 16(2), 23-46.

Pecqueur B., Zimmermann J.-B., 2004. Économie de proximité. HermesLavoisier, Paris.

Raina R., 2011. Institutional Strangleholds: Agricultural Science and the 
State in India, In: Shaping India: Economic Change in Historical Perspective (Narayana D., Mahadevan R., eds), Routledge, New Delhi, 99-123.

Rastoin J.L., 2000. Une brève histoire de l'industrie alimentaire. Économie rurale, 255-256, 61-71.

Requier-Desjardins D., 1999. Les théories néo-schumpeteriennes de l'innovation sont-elles applicables à l'agro-alimentaire tropicale. In: L'innovation en agriculture (Chauveau J.-P., Comier-Salem M.-C., Mollard E., eds), Édition IRD, 65-80.

Ricardo D., 1817. On the principles of the political economy and taxation. John Murray, London. $<$ http://www.econlib.org/library/Ricardo/ricP.html t> $>$ (retrieved 5 July 2018).

Robin P., Aeschlimann J.-P., Feller C., 2007. Histoires et Agronomie. IRD Éditions, Montpellier.

Rogers, E. M., 1976. New product adoption and diffusion. Journal of consumer Research, 2(4), 290-301.

Ruttan V., 1996. What Happened to Technology Adoption-Diffusion Research? Sociologia Ruralis, 36(1), 51-73.

Sardan (de) J.P., 1995. Anthropologie et développement : essai en socioanthropologie du changement social. Karthala, Paris.

Schumpeter J., 1934. The theory of economic development: an inquiry into profits, capital, credit, interest, and the business cycle. New Brunswick, New Jersey: Transaction Books. (Translated from the 1911 original German, Theorie der wirtschaftlichen Entwicklung.)

Seyfang G., Smith A., 2007. Grassroots Innovations for Sustainable Development: Towards a New Research and Policy Agenda. Environmental Politics, 16(4), 584-603.

Spielman D., 2006. Systems of Innovation: Models, Methods, and Future Directions. Innovation Strategy Today, 2(1), 55-66. 
Sumberg J., Okali C., Reece D., 2002. Agricultural research in the face of diversity, local knowledge and the participation imperative. Agricultural Systems, 76, 793-753.

Temple L., Compaore Sawadogo E., 2018. Innovation Processes in AgroEcological Transitions in the Developing Countries. ISTE / Wiley.

Touraine A., 1978. La voix et le regard. Seuil, Paris.

Touzard J.-M., Temple L., Faure G., Triomphe B., 2014. Systèmes d'innovation et communautés de connaissances dans le secteur agricole et agroalimentaire. Innovations - Revue d'économie et de management de l'innovation, 43, 13-38.

Vanderpooten M., 2001. Éléments techniques d'une révolution agricole au début de l'époque contemporaine. Doctoral thesis in history, Université Toulouse 2.

Vinck D., 1999. Les objets intermédiaires dans les réseaux de coopération scientifique. Contribution à la prise en compte des objets dans les dynamiques sociales. Revue française de sociologie, 40(2), 385-414.

Von Hippel E., 2005. Democratisizing innovation. The MIT Press, Cambridge.

Weber M., 1904. Capitalisme et société rurale. French translation published in Tracés. Revue de Sciences humaines, 2015, 29, 133-158.

\section{Chapter 2}

\section{Agricultural and agrifood innovation in the 21st century: maintaining, erasing or reshaping its specificities?}




\section{JEAN-MARC TOUZARD}

Summary. This chapter analyses the current characteristics of innovations in the agricultural and agrifood sector, exploring the nature and evolution of their sectoral specificities. Despite globalization, these innovations retain features specific to the relationships that agricultural and food activities have with nature, space and their societies. This specificity also depends on historical configurations of actors, institutions and knowledge that orient innovation and constitute agricultural innovation systems. However, agricultural and agrifood innovations are today marked in particular by the convergence of global challenges, as shown by research into transitions, be they ecological, climate-driven, digital, social or concerning food. The specificities of agricultural and agrifood innovations are being reshaped in the transitions underway, but their future evolution depends on the confrontations between different models of food production, exchange and consumption.

Since Neolithic times, the activities of food production, exchange and consumption have been constantly evolving, incorporating new techniques, organizations or institutions, and offering new agricultural or food products (Malassis, 1996). While the contents, the frequencies and the scale of these innovations differ depending on historical periods and geographical contexts, their emergence and their dissemination at a global scale have accelerated over the last two centuries. Consequently, one question is being asked repeatedly by agronomists, economists and rural sociologists, and by scientists who study the sectoral dimensions of innovation (Chambers et al., 1989; Sebillotte, 1996; Chauveau et al., 1999; Malerba, 2004; Touzard et al., 2014): What are the characteristics specific to agricultural and agrifood innovations and should not these specificities be disappearing in the context of the globalization of human activities? In this chapter, we will concentrate on this question in order to uncover and explore the current characteristics of agricultural and agrifood innovations. As a first step, we will show that, despite globalization, these innovations retain features specific to the relationships that agricultural and agrifood activities have with nature, space and societies. We will then confirm that this specificity also results from particular configurations of actors, institutions and knowledge which constitute agricultural innovation systems. We will then develop the idea that agricultural and agrifood innovations are also marked today by the convergence of global challenges, as shown by research on transitions of agrifood systems. We will conclude by suggesting that even though the 
specificities of agricultural and agrifood innovations are being reshaped in the current transitions, they remain at the heart of a possible confrontation between different models, offering several perspectives for the continued existence - or not - of these specificities.

\section{The importance of relationships with nature, space and societies}

While some authors suggest that the globalization of human societies leads to a standardization of behaviours and forms of production and exchange (Fukuyama, 1992), the examination of the characteristics specific to agricultural and agrifood activities suggests instead the continuance, even the renewal, of the original features that are likely to mark innovations in these sectors. These specificities can be approached first from an anthropological perspective by analysing the three relationships that underpin these activities.

\section{The relationship with the living world and nature remains at the heart of innovation}

First, agricultural activities and food products rely on relationships that are specific to the living world and nature: food is the product of biological systems (plants, animals, micro-organisms) that remain largely dependent on the Earth, its climates and ecosystems, and is ultimately ingested by a human body. Not only do these biological foundations underpin the fields of research intervention and innovation (agronomy, genetics, zootechnics, food technologies, nutrition, etc.) but, more importantly, they also determine the conditions under which actors can implement change. Nature's importance is reflected in the instability of agrifood flows, dependent as they are on the seasonality of agricultural production, the fragility of ecosystems, climate risks and the perishability of many products (which therefore have to be processed in order to be conserved), as well as on health issues (Colonna et al., 2012). The profitability of agricultural investments is therefore often tied to the short duration of a single stage of biological development (the harvest, for example). Due to climate and health hazards, innovation is also often 
more risky than in other sectors and, as a result, faces various forms of resistance from farmers, who are therefore sometimes described as 'riskaverse' (Ghadim et al., 2005). The biological act of ingesting food can also be considered as one of the foundations of its symbolic dimension, determining the permitted or forbidden fields of innovation (Muchnik et al., 2007). The social representations of nature and the living world, and their historical evolutions, are indeed important considerations for innovation, as recent contentious debates on genetically modified organisms (GMOs) and on the status of animals in food systems have shown (Porcher, 2017). This relationship with the living world and nature is expressed in an ambivalent way in innovations: the historical succession of technological changes can be seen as a long process of artificialization, of a reduction of this dependence on the living world, and of a denaturalization of the biological entities constituting the trophic networks (animals, plants, soil micro-organisms, etc.), resulting in greenhouse cultivation, non-soil cultivation, in vitro meat production, etc. But this history is also marked by movements in the opposite direction, which once again place nature at the heart of innovation, such as agroecology (Chapter 4), organic farming and new 'natural' foods. Even though this physical and nature-sensitive relationship is partly masked from the urban consumer by the succession of technical and commercial operations within value chains, it is also made visible afresh through the marketing of firms or the establishment of new direct links between food consumers and food producers, which, according to some authors, is merely a reflection of a quest for nature that is inherent to human beings (Tétart, 2003). Adversary, constraint, foundation or opportunity, nature remains well and truly at the heart of agricultural and agrifood innovation.

\section{Innovations that are tied to space}

In addition to this relationship with nature, agricultural activities have relationships with the space in which they take place. These relationships, too, influence the innovations in the sector. Land is primarily a physical platform for the practice of agriculture: while many technical and organizational changes directly concern ploughing of the soil and various types of movement over land (motorization, herd management, transport of harvests), the heterogeneity of space also comes into play in order to locate 
crops optimally or adapt practices, which is today one of the bases of innovations in precision agriculture[12] (Bordes, 2017). Development and management of the land is itself an area of innovation (terraces, reparcelling, drainage and irrigation systems) and has long formed one of the foundations of agricultural progress, promoted in France by the rural engineering corps. This relationship to space more broadly influences agricultural innovation through issues concerning land uses and rights (the role of tenure on investment), competition for land use (cultivation of new crops, links between cultivation and livestock farming) or even transportation that ensures supplies and sales for innovators (Chauveau et al., 1999). It also refers to social representations about space, taking its attributes, uses and value into account (Di Méo and Buleon, 2005). Thus, patrimonial aspects of agricultural land are often a key to understand investment and innovation choices at the scale of agricultural enterprises (Pichot, 2006) or territories (Perrin and Soulard, 2017). The evolution of representations of space in societies also influences the emergence of food products with geographical-origin attributes (Marie-Vivien and Bienabe, 2017) or, more broadly, the history of the links between food, rural communities and cities (Ariés, 2016). Finally, representations and functions pertaining to agriculture's spatial aspect are opening up new areas of innovation today, such as prevention and control of wildfires, eco-grazing and, more broadly, the production of environmental services (Gascuel and Magda, 2015). Geographically located agricultural and food innovations thus appear to have a dual relationship to space, attempting either to extract themselves from spatial constraints or to derive specific benefits that this spatial anchoring can provide.

\section{Food innovation as a social relationship}

The third fundamental relationship is the one between human beings in a society. It makes food production and supply a social act that involves the relationships and norms that structure the life of human communities (Fischler, 2013). This relationship with others in order to feed oneself orients innovation in food systems, from agriculture and its suppliers to the marketing of the final product. Along with the relationship with nature mentioned above, the relationship with others is the basis for food norms (cultural, religious, ethical, administrative, etc.) that permit, prohibit or 
favour certain agricultural products or techniques. More widely, this relationship defines conditions of food use and sociability, especially around a meal, whether with family, individually, collectively or at a festive occasion. These conditions are taken into account not only in the innovations of agrifood enterprises (composition, packaging, and marketing of products), but also in those of some farmers, when their products are highly valued as food, such as wine in France, valued because of its gastronomic aspect. More fundamentally, perhaps this relationship to others refers to the mechanism of mimetic rivalry (Girard, 1996). In addition to satisfying a nutritional need (and sometimes that of survival), food acquires a social value because the other designates it as desirable, which is the basis of food socialization. This mechanism may explain how social distinctions are associated with food, including most notably the desire for food consumed by higher classes (Bourdieu, 1979), explaining the development and marketing of new products. While this aspirational process no doubt encompasses many types of goods that are considered markers of social positioning, food retains a special place, especially because it can be shared (Cardon, 2017). The conditions of food use and sociability are today subject to the transformations of postmodern societies, reconciling the quest for individual and immediate well-being with a critical stance on progress and a willingness to reconstruct meaning and social bonds (Charles and Lipovetsky, 2004). With variations across countries, these evolutions are redefining the conditions conducive to agrifood innovation not only around the individualization of a part of the food consumed or emphasis on health issues, but also around the increased importance accorded to ethical foods or those that link producers to consumers in short supply chains. At the same time, on a global scale, cultural food differences remain significant (CEP, 2017). They retain an identity value (observable in domestic practices and restaurant menus) for many communities, including in urban areas, and thus orient some agrifood innovations despite the establishment of industrial standards (Rastoin and Ghersi, 2010). The relationship with others thus continues to be built around food, constructing social frameworks for agricultural and agrifood innovation that now combine postmodernity with the influence of inherited cultures.

These relationships with nature, with space and with others therefore condition innovation in agriculture and the agrifood sector and place it in a fundamental tension between the rejection of influence that is inherent to 
each relationship (artificialization, delocalization, individualization) and its permanence or reactivation (incorporation of nature, of space, and of others).

\section{Wpecific configurations of actors, institutions and knowledge}

Actors, institutions and knowledge have come up throughout history on the basis of these relationships, enabling coordination and regulation of agricultural and food activities, orienting innovation, and constituting sectoral innovation systems (Malerba, 2004).

\section{Farmers confronted by a concentration of firms and public actors}

Agricultural and agrifood activities are thus undertaken by specific configurations of actors and organizations that influence innovation in these sectors. Agronomic research centres, training organizations (agricultural colleges, agricultural engineering schools, agricultural universities) and development organizations (technical institutes, chambers of agriculture, agricultural planning and engineering companies, producer associations) across the world are today striving to construct new knowledge and knowhow for use in agriculture and the food sector. They have to contend with the fragmentation of farms, which are largely family-owned, and, conversely, with a high concentration of upstream firms (supplies of inputs and equipment), financial service providers (banks and insurance companies) and downstream companies (agrifood processing and distribution). Many specific types of actors, such as associations, consultancy firms, agricultural and agrifood unions, and specialized media, also play the role of intermediaries for innovation in these sectors (Klerkx and Leeuwis, 2009). This configuration of actors varies from country to country (higher concentration of farms in Britain, greater influence of mass retailing in France, agrarian dualism in Latin America, role of non-governmental organizations in Africa, etc.) or depends on the product (lower concentration of actors in processing and trading in the wine sector). But this general configuration is found around 
the world and represents a sectoral marker. The fragmentation of agricultural producers can thus explain the significance of collective action in agricultural innovation and the importance of the role retained by public and professional organizations in ensuring economies of scale and scope in research and development activities, for example to experiment with new practices (Faure et al., 2014). It can also explain the importance of innovation networks based on local links between farmers (Chiffoleau and Touzard, 2014). Conversely, the high concentration of firms upstream and downstream of agriculture is associated with a very strong industrial development of innovation based on internal research-and-development services, international strategic alliances, and patent repositories and acquisitions. This structural contrast between the multitude of individual farmers, private industrial oligopolies, and the mass of consumers is fundamental to apprehending the debates on agricultural innovation and the role played by the State, professional organizations and the media. This applies in particular not only to the control over seeds, biotechnologies and the food products themselves, but also to the use of inputs, the management of information and the choice of agricultural practices.

\section{Innovations framed by sectoral institutions}

More broadly, these actors act and innovate within the framework of particular institutions, historically constituted at the sectoral scale, and marked by the primarily strategic dimension of food for the States and their populations. Agricultural and food policies are these frameworks' formal expression, supporting, orienting and framing innovation at the regional, national or international level, directly (support for research and innovation) or indirectly (through investments, regulations, prices, training, etc.). In Europe, the Common Agricultural Policy (CAP) reflects this institutionalization of support for innovation, which has become more explicit since 2006 with the establishment of European partnerships for innovation (Brunori et al., 2013). In France, the establishment of Combined Technology Networks (RMT) and Economic and Environmental Interest Groups (GIEE) also illustrates this institutionalization, with the reconfiguration of the development institutions originally set up starting in the 1960s (Hervieu et al., 2010). In countries of the Global South, such 
institutions have been marked by projects funded by international donors, concerning agricultural research or advice, to support and accompany the Green Revolution since the 1960s. The recent emergence of 'agricultural innovation platforms' is yet another illustration (Faure et al., 2014). But we must also remember the role of less formal institutions created over time, both in the Global North as in the Global South, concerning access to resources and the organization of production (such as tenant farming, sharecropping, rules for organizing family work, the status itself of the farmer, etc.), of commerce (fairs, agricultural exhibitions and markets, the creation of standards, labels and geographical indications, etc.) and of consumption (catering norms, food standards, etc.). These institutions combine objective rules and trade-offs between different social representations (conventions) that define food quality. They show the way to innovate within the framework of sector-specific regulations (Allaire and Boyer, 1995). The example of geographical indications, mainly pertaining to agrifood products, is an apt illustration. They embody a mark of a quality based on conventions and a codification of practices (specifications of fair and consistent uses), which conditions the innovations possible (Belletti et al., 2017).

\section{Specific combinations of practical and scientific knowledge}

The very nature of the knowledge involved in productive and innovative processes is such that it can be considered original (Laurent and Landel, 2017). Knowledge building in agriculture and the agrifood sector, and the related training needs, concern not only several disciplines and technical fields (ranging from agronomy to food technologies and commercial technologies) but also the need for adaptation and local experimentation of generic knowledge (a consequence in particular of relationships with the natural environment). It also involves acknowledging the importance of tacit knowledge acquired and transmitted through practice, especially among farmers. This multidisciplinarity and this combination of scientific and practical knowledge justifies agricultural education and the applied character of agronomic science (Chapter 3). Since the knowledge associated with certain agricultural innovations can be distributed among the actors 
concerned, it can also, as a result, be more difficult to protect through intellectual property rights, a possible reason for the reticence of the private sector to invest in innovation. In addition, the existence of agricultural advisory services (public, professional or private) in all countries shows that while the combination and specification of knowledge for agricultural innovation is of strategic importance and even though it is expensive, it is potentially effective (Labarthe and Laurent, 2013). The growing importance of consumer-citizen knowledge is also orienting innovation, as it does in other sectors (so-called 'user innovations'), but with specific characteristics, sometimes related to the possibility that consumers have of experimenting in a vegetable garden and sharing the knowledge gained at a farmers' food market (Chiffoleau and Prévost, 2012), or to contribute to participatory certification approaches (Mundler and Rouchier, 2016). Finally, scientific knowledge itself is being used in new ways in public debates on agricultural and agrifood innovation (Joly, 2016). Beyond its conventional contributions upstream of innovation, scientific knowledge is playing a growing role in underpinning expertise and in legitimizing innovations, as shown by the proliferation of expert groups on the use of biotechnologies or on the links between food and health.

\section{Building agricultural innovation systems}

The historical and joint construction of networks of actors, institutions and knowledge ensures the regulation of agricultural and agrifood activities and helps provide a framework for the innovations that transform them, while maintaining sectoral and national specificities (Touzard and Labarthe, 2016). The notion of the sectoral innovation system has been proposed to better study the conditions conducive to innovation (Malerba, 2004). Since it is found to be fully applicable to agriculture and the agrifood sector, some authors have proposed concepts such as the Agricultural Innovation System (AIS) or the Agricultural Knowledge and Innovation System (AKIS) (Klerkx et al., 2010). Historical, comparative, comprehensive and operational approaches use these concepts (Touzard et al., 2014). They show the emergence of actors and national institutions across the world formally dedicated to agricultural and agrifood innovation. Often, two major modalities coexist in each country: on the one hand, a system based on public 
agronomic research, universities and, sometimes, partnerships with private firms, which is generally top-down in nature, and on the other, systems which, on the contrary, derive value from collaborations between farmers (grassroots innovation) or between different actors of the agrifood sector. National agricultural innovation systems may also coexist with other, more or less autonomous innovation systems, which are organized around major products (coffee, cocoa, cotton, wine, milk, etc.), regions (in particular in countries with federal structures) or production models (organic farming, as in many European countries). This architecture of institutions, actors and knowledge clearly appears to be a specificity of the agricultural sector (Labarthe, 2005).

\section{Wenewed global challenges are driving agricultural and agrifood innovation}

The specificity of innovations in the agricultural and agrifood sectors depend, of course, on the characteristics of activities in these sectors but they can also arise from the renewed challenges they face, such as environmental degradation, climate change, food security, the fight against poverty, technological revolutions, etc. Political projects take these challenges into account by attempting to reorient agricultural and food activities to make their innovations part of transitions. Since the beginning of the 2000s, several authors have proposed incorporating innovation into transitions by considering several analytical levels ('multi-level perspective'), especially the level of the niche at which an innovation appears, and that of the sociotechnical system in which a sector's operating regime is institutionalized, irrespective of whether it incorporates these innovations or not (Geels, 2010). An examination of the political issues that confront agricultural and agrifood innovations then reveals the various transitions - agroecological, climatic, energy, food, social, or technological - of which they can be part.

\section{Innovating for the ecological transition}

Most importantly, the evolution of agriculture and the food sectors has to contend with a rapid degradation of natural resources. Biodiversity is the 
primary victim, highly impacted by deforestation, agricultural specialization and the use of pesticides in industrial agriculture. The challenge also concerns management of the soil, impacted by agriculture in many regions (erosion, decline in fertility, etc.), and of water, overused for irrigation or polluted by pesticide or fertilizer residues. Agricultural and agrifood activities are also at the heart of the crises of the nitrogen and phosphorus cycles (Rockstrom et al., 2009). Today, their negative impacts even threaten agricultural productivity in many regions (OECD/FAO, 2016). Agriculture and food production are thus at the centre of environmental debates, not only because they are partly responsible for the observed deteriorations, but also because they are part of the solutions to remedy them. On the one hand, certain forms of agriculture can indeed provide environmental services (landscape opening, biodiversity restoration, wildfire prevention and control, regulation of water cycles, etc.) and, on the other, consumers can insist on the adoption of more ecological practices all along the food chains, including in agriculture. Through this double contribution, agricultural and food innovations can thus become part of an ecological transition, following technological paths that are still being debated and which are sometimes conflicting (Vanloqueren and Barret, 2009):

- optimizing the use of inputs and mitigating their impacts, while continuing with the system of industrial agriculture, through the use of genetically modified organisms, the reduction of toxicity, volume and/or the frequency of use of pesticides, the switch to precision or integrated agriculture, etc.;

- stopping the use of inputs or operations such as ploughing (Goulet and Vinck, 2012) and adopting practices such as integrated pest management to allow the ecological intensification of agriculture (Aggeri, 2011);

- converting to organic farming, which has become a socio-technical regime in some countries (Lamine, 2011);

- adopting more radical forms of agroecological practices, such as permaculture, incorporating new knowledge on the role of soils, trees, legumes, self-production of inputs, or crop associations (Ingram, 2017); - recognizing and improving existing farm practices that are little known or poorly supported (agroforestry in the Global South, extensive livestock husbandry in the mountains, etc.).

The innovations of this agroecological transition are being supported by new networks and institutional mechanisms at the local level (associations, clubs 
and networks), the national level (for example, the Agroecological Project for France, promoted in 2013) and the international level (initiatives of the Food and Agriculture Organization of the United Nations, Convention on Biological Diversity, International Forum for Agroecology). They are driven by a social and scientific movement (Wezel et al., 2009) and are the subject of political confrontations that are playing out in the media and legislative arenas (Aulagnier and Goulet, 2017; Sabourin et al., 2017).

\section{Innovating to respond to the challenge of climate change}

Climate change has also become a major challenge for agriculture. Agriculture is, indeed, the sector that accounts for the second largest emission of greenhouse gases ( $24 \%$ of all worldwide emissions), mainly from livestock husbandry, rice farming, deforestation and the use of synthetic fertilizers (Soussana, 2013). At the same time, agriculture is also increasingly being recognized for the role it can play in mitigating climate change because of its ability to sequester carbon (in soil, in biomass, etc.) and through possibilities of reducing emissions - which are more realistic than grandiose geoengineering projects. Agriculture is also one of the sectors most vulnerable to the effects of climate change, reflected not only in the variability and fall in yields, but also in the quality of products and agricultural geography (forced relocation of production, evolution of landscapes, competition for resources, etc.). Agriculture and the agrifood sector are therefore among those most interested in both mitigating climate change as well as adapting to it, thus justifying the search for innovations for a 'climate-smart' agriculture. There are different and sometimes conflicting visions of this agriculture, in particular as concerns the nature of innovation and its control: should it be essentially technological and driven by the research community and firms or should it concentrate instead on learning from and using local and peasant innovations? Non-governmental organizations have taken a stand against climate-smart agriculture, viewing it as an attempt at 'greenwashing' by companies wanting to maintain their control over agriculture. Other organizations, such as Climate-KIC, push a technological vision that is claimed be compatible with different forms of agriculture. Some others see climate-smart agriculture as an opportunity for 
agriculture in countries of the Global South (Torquebiau, 2015) or consider it primarily as a political project for mobilization for a climate transition (FAO, 2013). Agriculture is also being linked to energy issues. While it is indeed a consumer of fossil energy for production (energy required for the synthesis of certain inputs and for motorization) and for logistics, it also produces energy itself from biomass (alcohols, oils, methane, etc.) as well as items that can substitute those made using fossil fuels. The energy transition can thus bring back other forms of mechanization such as animal traction, especially in the countries of the Global South. But, more drastically, agriculture is also finding a place in the bio-economy (Colonna et al., 2012). It is a new field of innovation that encompasses a diversity of technical and organizational options, in particular contrasting large-scale organized supply chains constructed around biorefineries and mass agricultural production (sugarcane, maize, oilseeds, etc.) with niches in which the local use of energy from agriculture is being tested. Here too, agriculture, which has become a fossil fuel-dependent sector in many countries, is the subject of controversy and major political debate, calling into question, for example, arguments in favour of the current production of agrofuels (Allaire and Daviron, 2017).

\section{Innovating to contribute to food security}

Furthermore, given global population growth and changing conditions of food production, exchange and consumption, food security has become once again a major challenge, brought to centre stage by the food crisis of 20072008 (Heady and Fan, 2011). Cyclical factors (droughts, wars, rising oil prices, financial crash) aside, this crisis revealed structural changes in demand (competition by biofuels, growth of food consumption in the form of animal calories, etc.), in production (stagnation of yields, decrease in public and private investments in agriculture, etc.) and in trade (financialization of agricultural markets, reduction of stocks, liberalization of national agricultural policies, etc.). This food crisis showed the limitations of the agricultural development and innovation model promoted internationally since the 1950s, which was subsequently liberalized and financialized (Allaire and Daviron, 2017). Food security concerns not only the availability, quality (especially pertaining to health and nutrition), affordability and regularity of access to food but also the ability of people and countries to 
define and control their food production and supply. Innovations that can contribute to the improvement of these different dimensions of food security, i.e. to food securitization (Touzard and Temple, 2012), can be of very different types, including, for example, those concerning new cropping systems as well as those designed to cover or mitigate risks in an agrifood market. They are implemented or act at different scales, ranging from the household unit to sectoral policies and global value chains. These innovations must be apprehended in their complementarity and coherence, and combined with institutional changes, modifications in diets, the redefinition of strategies of firms and public actors, and the building up of the capacities of actors (education). But the multiplicity of dimensions of food security (not necessarily all attainable at the same time), the strong geographical differences in food issues, and controversies over the political aspects of food sovereignty or over technological options (agro-industrial regime $v s$ an agroecological one) leave the scope of possible innovations wide open.

\section{Innovating to meet social challenges}

Poverty reduction and capacity building of populations are also major challenges facing agricultural and food activities, especially in the least developed and middle-income countries, with large and very poor agricultural populations. Globally, almost $75 \%$ of families living below the poverty line reside in rural areas and depend on agriculture (World Bank, 2016). Access to education and health is also more limited in rural areas. Innovation in agriculture and the agrifood sector presents multiple and contradictory links with these challenges. In its 'destructive' avatar, innovation can be a cause of the economic marginalization of many farmers, who become no longer able to make a living because of the relative decline in agricultural prices. It can also increase land concentration and human migration. In its 'creative' avatar, innovation can instead promote rural entrepreneurship, give a boost to value creation in rural areas, and explicitly target social issues of training and inclusion (McIntyre et al., 2009). It can thus help reduce disparities and build capacities, and hence provide freedoms (Sen, 1999). This is what is at stake, for example, in the movement of the social and solidarity economy in agriculture, or in the motivation behind the emergence of niches of social innovation in the sector (Chapter 5). Issues of 
democracy and human rights - in addition to those of inequality and poverty - are also involved. Agricultural and food innovations can indeed erode these rights when these innovations' proponents are actors (firms, government authorities, agricultural organizations, etc.) whose aim is to strengthen a socio-technical system that runs counter to positions expressed by local communities (De Schutter, 2014). But agriculture and food production are also domains of awareness raising and affirmation of projects that can contribute to political life and democratic expression (Renting et al., 2012). For example, struggles for land continue in many countries (movements against land grabbing or spread of real estate projects). The demand for a better quality of food for all generates niches of social innovation, which join participatory and open approaches to innovation (Chiffoleau and Prévost, 2012).

\section{Innovating in the context of two major technological revolutions}

And finally, agriculture and the food sector are also being influenced by two major technological revolutions of the early 21 st century: the digital revolution and the biotechnology revolution. These are generic and exogenous developments that are already having - and have the potential for even greater - impacts on the sector and all of its innovations. The use of new information and communication technologies (NICTs) in agriculture, initially in precision agriculture, extends to a wide variety of innovations such as sensors, robots, satellite guidance, embedded computing, digital applications for herd management and irrigation, decision support tools, etc. Various digital applications are forming the basis for connected or digital agriculture (Bellon-Maurel and Huyghe, 2016), transforming agricultural work and farm management. While most of these innovations are promoted by firms and research-and-development organizations linked to industrial agriculture, new actors are emerging (digital and start-up firms, associations and nongovernmental organizations) and leading to the creation of new innovation networks, benefiting from the growth - and concomitant steep decline in the cost - of digital equipment and services, including in countries of the Global South. There are proposals for new services and to make digital agriculture a path to sustainable agriculture (Walter et al., 2017) or even agroecology 
(Bonny, 2017). But significant controversies exist regarding the control and ownership of information and of innovations in digital agriculture, and the possibility of exclusion of some farmers (Mazaud, 2017).

Biotechnologies came into their own in the 1990s, in particular with the creation and marketing of genetically modified seeds. The new knowledge and expertise in genetics and biology is usually applied upstream of many agrifood innovations, ranging from the creation of varieties (irrespective of whether they result in genetically modified organisms) to in vitro meat production, the production of biomolecules or the treatment of agricultural waste. Because biotechnological innovations in agriculture directly affect the living world (see above), the debates surrounding them are focused on important ethical, political and legal dimensions in order to be able to characterize and manage the associated risks (Joly, 2016). These debates are all the more vigorous and lively because the economic stakes involved are considerable, and are driven by a handful of multinational firms, research centres, small- and medium-sized enterprises (SMEs), and business clusters. They are changing the positions and reconfiguring power relations within agricultural innovation systems (Laperche, 2009). While digital and biotechnological innovations certainly find place in the socio-technical regime of agriculture and industrial food production, they also help niches emerge, which can be incorporated or not into this regime, and can hybridize with different forms of agriculture, such as organic farming.

\section{From the political challenges of innovation to the contribution to transitions}

The challenges presented here are not all specific to the agricultural and agrifood sector, or do not have the same intensity across products and countries. While the challenge of food security is unique to the sector, ecological and climatic challenges concern it to a very significant extent but not solely. And even though digital technologies, biotechnologies and social issues are common to many sectors, they have a strong influence over the evolution of agricultural and agrifood activities. And yet, the convergence of these challenges at the beginning of the 21 st century is a specific and unprecedented situation, giving a very political dimension to agricultural and 
agrifood innovation across all levels, from the local to the international. Taking the political construction of these challenges and their axiological power (i.e. the meaning they can give to innovations) into account leads to the inclusion of agricultural and food innovations in various transitions. These transitions are closely linked and contribute to the same major transformation of agriculture in human society. The processes involved within each of these challenges are indeed interdependent, for example climate change, which accelerates the loss of biodiversity, increases food risks, and exacerbates the social disparities between the Global North and the Global South. Furthermore, each agricultural or agrifood innovation usually addresses several challenges, being able to respond positively to some, but often negatively to others. Finally, these different challenges are also combined (and sometimes obscured) in policy projects that advocate different agrifood models or their coexistence (Touzard and Fournier, 2014) and which are under debate, in competition or confrontation in each transition.

\section{Conclusion: the specificity of innovations is being reshaped, but is not immutable}

Examining the evolution of the specificities of agricultural and agrifood innovations in a context of globalization has led us to examine three sets of factors, each associated with a different approach to agriculture and its innovations. From an anthropological perspective, we first showed that relationships with nature, space and society continue to mark the sector's innovations, but through a dialectic in which forces that are attempting to exclude nature, space or society are pitted against those that seek to renew and re-emphasize their expression, and thus to reconstruct a sectoral specificity. The analysis of the configurations of institutions, actors and knowledge then confirmed that agricultural and agrifood innovations remain highly dependent on sectoral innovation systems, which are traversed by a variety of processes that can challenge or recompose them. Finally, by referring to the approaches to transition, we examined a set of global challenges facing agricultural and agrifood innovations, highlighting their unprecedented convergence and their very political dimension in the current context. 
Globalization has therefore not eliminated the specificities of agricultural and agrifood innovations. Indeed, it even tends to renew them, given the convergence of the transitions in which the sector is engaged. The specificity of these innovations emerges from the co-evolution of the anthropological relationships that underpin these activities, the innovation systems built to regulate them and the global challenges they must address. Influenced by numerous, sometimes contradictory, processes, the specificity of these innovations is neither a given nor is immutable. Three observations help us maintain an open perspective on the future evolution of agricultural and agrifood innovations and the regimes to which they belong:

- our general approach to innovation should not obscure the diversity of their concrete forms, more or less specific depending on the products, geographical location, activities (ranging from agriculture to catering) or the nature of innovations (technical or organizational, incremental or radical, exogenous or endogenous); this diversity is not only part of the overall functioning and regulation of the sector, but can also be a basis for its possible breakup;

- these innovations refer to different agricultural and food production models that go beyond the 'industrial vs alternative' divide (Touzard and Fournier, 2014), and in particular to models of differentiated quality (naturalistic, ethical, or pertaining to heritage or proximity); the coexistence of these models in most countries appears both as a feature of globalization and as a sectoral specificity; while innovations can be part of each of these models, they can also result from their combinations and interactions; the dominant position of the agro-industrial model, and in particular its control over biotechnologies, suggests however the long-term possibility of a loss of sectoral specificity, through, for example, the pursuit of artificialization of food production, such as in vitro meat production, and this, despite the sustained challenges that this model is being subjected to;

- the very political dimension of innovation emphasized by our analysis highlights how transitions are managed at different scales, from the local to the international; however, at the international level, political agreements remain largely open, between the revival of a neoliberal governance of agriculture and food production, a return to bilateral relationships associated with regional regulations or the construction of a multilateral and civic world governance. 
Each option reflects a different view of the place of agriculture and food production, its innovations and its specificities. The issue of the sector's contributions to the production of public goods is thus key and open to debate. The recognition of these contributions could then give agricultural and agrifood innovations a more secure and specific position in the transitions currently underway.

\section{Bibliography}

Aggeri F., 2011. Le développement durable comme champ d'innovation : scénarisations et scénographies de l'innovation collective. Revue française de gestion, 215(6), 87-106.

Allaire G., Boyer R. (eds), 1995. La grande transformation de l'agriculture. Inra-Economica, Paris.

Allaire G., Daviron B., 2017. Transformations agricoles et agroalimentaires : entre écologie et capitalisme. Éditions Quæ, Versailles.

Ariés P., 2016. Une histoire politique de l'alimentation. Éditions Max Milo.

Aulagnier A., Goulet F., 2017. Des technologies controversées et de leurs alternatives. Le cas des pesticides agricoles en France. Sociologie du travail, 59(3).

Belleti A., Marescotti A., Touzard J.-M., 2017. Geographical Indications, Public Goods and Sustainable Development: The roles of actors' strategies and public policies. World Development, 98, 45-57.

Bellon-Maurel V., Huyghe C., 2016. L'innovation technologique dans l'agriculture. Géoéconomie, 80, 159-180.

Bonny S., 2017. High-tech agriculture or agroecology for tomorrow's agriculture? Harvard College Review of Environment \& Society, 4, 28-34.

Bordes J., 2017. Numérique et agriculture de précision. Annales des Mines, 87(3), 87-93. 
Bourdieu P., 1979. La distinction. Éditions de Minuit, Paris, 670 p.

Brunori G., Barjolle D., Dockes A., 2013. CAP Reform and Innovation: The Role of Learning and Innovation Networks. Euro Choice, 12(2), 27-33.

Cardon P. (ed.), 2017. Quand manger fait société. Presses Universitaires du Septentrion, Lille.

CEP, 2017. MOND'Alim 2030 : panorama prospectif de la mondialisation des systèmes alimentaires. La Documentation française, Centre d'étude et de prospective du ministère de l'Agriculture, Paris.

Chambers R., Pacey A., Trupp L., 1989. Farmer first: farmer innovation and agricultural research. Intermediate Technology Publications, London.

Charles S., Lipovetsky G., 2004. Les temps hypermodernes. Grasset, Paris.

Chauveau J.-P., Cormier Salem M.-C., Mollard E. (eds), 1999. L'innovation en agriculture: questions de méthodes et terrains d'observation. Éditions Orstom-IRD, Paris, 362 p.

Chiffoleau Y., Prévost B., 2012. Les circuits courts, des innovations sociales pour une alimentation durable dans les territoires. Norois, 224, 7-20.

Chiffoleau Y., Touzard J.-M., 2014. Understanding local agri-food systems through advice network analysis. Agriculture and Human Values, 31, 19-32.

Colonna P., Fournier S., Touzard J.-M., 2012. Systèmes alimentaires. In: Pour une alimentation durable (Esnouf C., Russel M., Bricas N., eds), Éditions Quæ, Versailles, 79-108.

De Schutter O., 2014. Les droits de l'Homme au service de la sécurité alimentaire. In: Penser une démocratie alimentaire (Collart Dutilleul F., Bréger T., eds), Inida, San José, 61-65.

Di Méo G., Buléon P. (eds), 2005. L'espace social. Lecture géographique des sociétés. Armand Colin, Paris, $304 \mathrm{p}$.

FAO, 2013. Climate Smart Agriculture Source Book. FAO, Rome. 
Faure G., Gasselin P., Triomphe B., Temple L., Hocdé H. (eds), 2014. Innovating with rural stakeholders in the developing world - Action research in partnership CTA - LM Publishers, 224 p. $<$ https://publications.cta.int/media/publications/downloads/1783 PDF.pdf $4>$ (retrieved 13 July 2018)

Fischler C., 2013. Les alimentations particulières. Mangerons-nous encore ensemble demain? Odile Jacob, Paris.

Fukuyama F., 1992. The End of History and the Last Man. Free Press.

Gascuel C., Magda D., 2015. Gérer les paysages et les territoires pour la transition agroécologique. Innovations Agronomiques, 43, 95-106.

Geels F.W., 2010. Ontologies, socio-technical transitions to sustainability, and the multi-level perspective. Research Policy, 39(4), 495-510.

Ghadim A., Pannel D., Burton M., 2005. Risk, uncertainty, and learning in adoption of a crop innovation. Agricultural Economics, 33(1), 1-9.

Girard R., 1996. Eating disorders and mimetic desire. College of Arts and Sciences, East Caroline University.

Goulet F., Vinck D., 2012. L'innovation par retrait. Contribution à une sociologie du détachement. Revue Française de Sociologie, 53(2), 195-22.

Heady D., Fan S., 2011. Reflections on the Global Food Crisis. IFPRI Research Monograph, $165 \mathrm{p}$.

Hervieu B., Mayer N., Muller P., Purseigle F., Remy J., 2010. Les mondes agricoles en politique. Presses de Science Po, Paris.

Ingram J., 2017. Agricultural transition: Niche and regime knowledge systems' boundary dynamics. Environmental Innovation and Societal Transitions, 24.

Joly P.-B., 2016. Science réglementaire : une internationalisation divergente? L'évaluation des biotechnologies aux États-Unis et en Europe. Revue française de Sociologie, 57(3), 443-472. 
Klerkx L., Aarts N., Leeuwis C., 2010. Adaptive management in agricultural innovation systems: The interactions between innovation networks and their environment. Agricultural Systems, 103(6), 390-400.

Klerkx L., Leeuwis C., 2009. Establishment and embedding of innovation brokers at different innovation system levels. Technological Forecasting and Social Change, 76(6), 849-860.

Labarthe P., 2005. Trajectoires d'innovation des services et inertie institutionnelle : dynamique du conseil dans trois agricultures européennes. Géographie, économie et société, 3, 289-311.

Labarthe P., Laurent C., 2013. Privatization of Agricultural Extension Services in the EU: Towards a Lack of Adequate Knowledge for Small-Scale Farms? Food Policy, 38, 240-252.

Lamine C., 2011. Transition pathways towards a robust ecologization of agriculture and the need for system redesign. Cases from organic farming and IPM. Journal of Rural Studies, 27, 209-219.

Laperche B., 2009. Stratégies d'innovation des firmes des sciences de la vie et appropriation des ressources végétales : processus et enjeux. Mondes en développement, 147(3), 109-122.

Laurent C., Landel P., 2017. Régime de connaissances et régulation sectorielle en agriculture. In: Transformations agricoles et agroalimentaires (Allaire G. and Daviron B., eds), Éditions Quæ, Versailles.

Malassis L., 1996. Traité d'économie agroalimentaire. Édition Cujas, Paris.

Malerba F., 2004. Sectoral Systems of Innovation. Cambridge University Press.

Marie-Vivien D., Biénabe E., 2017. The Multifaceted Role of the State in the Protection of Geographical Indications. World Development, 98, 1-11.

Mazaud C., 2017. À chacun son métier, les agriculteurs face à l'offre numérique. Sociologies pratiques, 34(1), 39-47. 
McIntyre B., Herren H., Wakhungu J., Watson R. (eds), 2009. International Assessment of Agricultural Knowledge, Science and Technology for Development (IAASTD): Global Report. Island Press, Washington, DC.

Muchnik J., Requier-Desjardins D., Sautier D., Touzard J.-M., 2007. Systèmes agroalimentaires localisés. Économies et Sociétés, série AG, 29, $1465-1484$.

Mundler P., Rouchier J., 2016. Alimentation et proximités. Jeux d'acteurs et territoires. Educagri, Dijon.

OECD/FAO, 2016. OECD-FAO Agricultural Outlook 2016-2025, OECD Publishing, Paris. <http://dx.doi.org/10.1787/agr_outlook-2016-en $\quad>>$ (retrieved 13 July 2018)

Perrin C., Soulard C., 2017. L'agriculture dans le système alimentaire urbain : continuités et innovations. Natures Sciences Sociétés, 25(1), 3-6.

Pichot J.-P., 2006. L'exploitation agricole : un concept à revisiter du nord aux suds. Cahiers Agricultures, 15, 483-486.

Porcher J. (coord.), 2017. Travail animal, l'autre champ du social. Écologie politique, 54, Éditions Le Bord de l'Eau, 187 p.

Rastoin J.-L., Ghersi G., 2010. Le système alimentaire mondial. Concepts et méthodes, analyses et dynamiques. Éditions Quæ, Versailles, 565 p.

Renting H., Schermer M., Rossi A., 2012. Building Food Democracy: Exploring Civic Food Networks and Newly Emerging Forms of Food Citizenship. International Journal of Sociology of Agriculture and Food, 19, 289-307.

Rockström J., Steffen W., Noone K., Persson A., Chapin F.S. III, Lambin E., Lenton T.M., Scheffer M., Folke C., Schellnhuber H.J., Nykvist B., de Wit C.A., Hughes T., van der Leeuw S., Rodhe H., Sörlin S., Snyder P.K., Costanza R., Svedin U., Falkenmark M., Karlberg L., Corell R.W., Fabry V.J., Hansen J., Walker B., Liverman D., Richardson K., Crutzen P., 
Foley J., 2009. Planetary boundaries: exploring the safe operating space for humanity. Ecology and Society, 14(2), 32.

Sabourin E., Patrouilleau M.M., Le Coq J.-F., Vásquez L., Niederle P. A. (eds), 2017. Politicas Publicas a favor de la agroecologia en America Latina. Cirad, Red PP-AL, FAO.

Sebillotte M. (ed.), 1996. Systems-Oriented Research in Agriculture and Rural Development. Éditions du Cirad, Montpellier.

Sen A., 1999. Development as Freedom, New York: Alfred Knopf.

Soussana J.-F., 2013. S'adapter au changement climatique. Éditions Quæ, Versailles.

Tétart G., 2003. Consommer la nature et parfaire son corps. Études rurales, 165-166, 9-31.

Torquebiau E. (ed.), 2015. Changement climatique et agricultures du monde. Éditions Quæ, AFD, Versailles.

Touzard J.-M., Fournier S., 2014. La complexité des systèmes alimentaires : un atout pour la sécurité alimentaire ? VertigO, 14, 2014.

Touzard J.-M., Labarthe P., 2016. Regulation Theory and Agriculture transformations: a literature review. Revue de la régulation : Capitalisme, Institutions, Pouvoir, 20, 2016.

Touzard J.-M., Temple L., 2012. Sécurisation alimentaire et innovations dans l'agriculture et l'agroalimentaire : vers un nouvel agenda de recherche ? Cahiers Agricultures, 21, 293-301.

Touzard J.-M., Temple L., Faure G., Triomphe B., 2014. Systèmes d'innovation et communautés de connaissances dans le secteur agricole et agroalimentaire. Innovations - Revue d'économie et de management de l'innovation, 43, 13-38.

Vanloqueren G., Baret P., 2009. How agricultural research systems shape a technological regime that develops genetic engineering but locks out 
agroecological innovations. Research Policy, 38(6), 971-983.

Walter A., Finger R., Huber R., Buchmann N., 2017. Smart farming is key to developing sustainable agriculture. Proceedings of the National Academy of Sciences USA, 114, 6148-6150.

Wezel A., Bellon S., Doré T., Francis C., Vallod D., David C., 2009. Agroecology as a science, a movement or a practice. A review. Agronomy for Sustainable Development, 29(4), 503-515.

World Bank, 2016. Who Are the Poor in the Developing World? Policy Research Paper, Poverty and Equity Global Practice Group, Washington DC.

\section{Chapter 3}

\section{Agricultural research and innovation: a socio-historical analysis}

\section{FRÉDÉRIC GOULET}

Summary. This chapter examines, in a socio-historical perspective, the place occupied by innovation in the field of agricultural research. While the notion of innovation is ubiquitous today, it is a time-honoured idea that science and technology can, and must, contribute to the transformation of agriculture. It has even been the basis of the establishment of national and international agricultural research institutions in the latter half of the 20th century. The transformation of the relationships between science, agriculture and society has, nevertheless, called this contribution into question in recent decades. In particular in the context of a crisis of confidence in the industrial agricultural model and transformations specific to the scientific field, there has been an evolution and diversification of expectations from agriculture. Agricultural research institutions have to cope with these developments, and regularly re-invent the terms of their contributions to innovation and to the transformation of agriculture.

How can a book on agricultural innovation which presents analyses from 
scientists, chiefly from agricultural research institutes, not include reflections on the relationships between these institutes and the development of innovations? Our aim in this chapter is to examine, from a socio-historical perspective (Payre and Pollet, 2013), the place occupied by the subject of innovation in the field of agricultural research. We show that, for more than half a century, profound transformations have affected the way in which agricultural research interacts with stakeholders in innovation processes, especially farmers. We note that while the objective of undertaking research to guide the transformation of productive activities and society has remained central, the modalities of doing so have, over time, taken various and diversified forms of activities and injunctions. Agricultural research here encompasses all institutions, policies and practices pertaining to the organization and conduct of scientific and technological activities related to agriculture. While this acceptation no doubt includes both public and private actors, we will mainly focus on the public sector, more specifically on French agricultural research institutes - in particular on the French National Institute for Agricultural Research (INRA) - rather than on universities, which combine higher education with research. By innovation, we mean all the technical novelties and changes in practices that affect or re-orient the practices of farmers or other agricultural production actors.

\section{Implementation of applied research}

Innovation is associated closely with scientific and technical activities in many sectors, and is also an outcome expected from research and development investments. Agriculture is no different in this regard and the creation of agricultural research institutes in the 20th century by nation-states was consistent with this logic. Sectoral and applied techno-scientific bodies were established during the time industrialized countries were adopting policies for agricultural modernization, and developing countries were embracing the Green Revolution model. These bodies were tasked with meeting goals defined by public policies on the basis of the role assigned to agriculture in society. Food autonomy of countries, increased export capacities, and the fight against world hunger (Cornilleau and Joly, 2014) thus constituted central mobilizing challenges around which dedicated scientific and technical capacities were created. Research activities focused 
primarily on the key issues of increasing productivity and agricultural yields, most often through technologies or artifacts directly involved in production processes, such as plant genetics and seeds (Kloppenburg, 2004; Bonneuil and Thomas, 2009). This scientific and technical apparatus created and organized by the State was itself a part of the public intervention designed not only to conceive technological innovations, but also to disseminate them to producers. This is why agricultural extension and development policies and institutions emerged, to take the achievements of laboratories or experimental stations and disseminate them to farmers and rural communities. In France, for example, policies for the professionalization of farmers (Rémy, 1987), or the growth of services aimed at supporting rural households in these transformations (Brunier, 2015), constituted, within the framework of agricultural 'co-management' (Coulomb et al., 1990), an essential facet of modernization policies. In any case, it is in this environment that agricultural research organizations, as we know them today, emerged, and which were given the explicit mandate of creating knowledge and technologies that could lead to a (r)evolution in the agricultural sector. Agricultural research has thus been conceived, from the very beginning, as an applied science, one that is able to generate results that can be appropriated by producers. However, despite this intention, various shifts have affected this proximity and operationality, and have led many actors to question the capacity of agricultural research institutions to come up with innovations.

\section{The diversification of scientific activities and the academic shift}

Activities of agricultural research institutes, their organization, and their relationship with their target audiences, have in fact evolved over time since their establishment. A major evolution concerns a dynamic internal to these institutes, arising from the significant changes affecting their agents and the nature of the knowledge they produce. First of all, scientific specialties and disciplines have progressively diversified, primarily towards agrifood technologies, and subsequently, specifically to the integration of the economic, human and social sciences, whose potential for application, while less directly related to the technologies themselves, had contrasted with the activities carried out until then. The introduction of certain disciplines such as 
sociology has, for a long time, been driven - and this is still the case in many emerging and developing countries - by a desire to account for the social factors facilitating or hindering the adoption by farmers of innovations conceived in laboratories or experimental stations. Subsequently, starting in the 1980s, the general evolution of the management and evaluation methods of scientific activities led in many cases to a dilution of the goal of designing innovations directly intended for the actors of agricultural modernization, or intended to respond to concrete problems that they face. Research activities have increasingly been planned according to the agendas of a globalized scientific community due to the growing specialization of research fields and a system for evaluation of researchers increasingly focused on bibliometrics (Gingras, 2014). In some industrialized countries, agricultural research has thus become a research activity 'much like any other', in the sense that it has embraced the transversal movement sweeping the entire techno-scientific world. The recruitment of new researchers has increasingly been based more on academic excellence and association with the academia than on the knowledge and experience of the agricultural world. In this respect, the social sciences are an excellent case in point, with institutes such as INRA in France gradually favouring mastery of theoretical frameworks and the ability to publish in academic journals, rather than an in-depth knowledge of agriculture and its issues. Furthermore, in France, the disappearance of rural sociology-based thematic networks from professional associations and scientific societies, such as the French Sociology Association, speaks volumes in this regard. The rural world and agriculture have become objects to be apprehended through more generic or generalist theoretical currents and traditions, such as sociology of work, sociology of professions or, more recently, sociology of the environment, sociology of sciences and technology or economic sociology[13].

Academic excellence has thus become a leading driver of agricultural research, being placed at par with the initial focus on application - without, however, supplanting it, as is explained at the end of this section. An increased distance from actors in the field is not the only result of these developments, since very often dialogue and collaborations between different disciplines and specialities within agricultural research institutes have become a real challenge. These institutions host a very wide range of specialists and disciplines that are often disconnected from each other, 
interacting with difficulty despite encouragement and injunctions to promote inter-disciplinarity. Thus, an agricultural economist will probably find more topics in common for discussion with a university lecturer-researcher in economics than with a wheat geneticist working in the laboratory next door, and more than this geneticist will find in common with a soil scientist he meets every day in the institute's cafeteria! Agricultural research has, again despite its operational vocation, been following a movement since the 1980s that sometimes contributes in shifting the goal away from producing innovations and knowledge directly applicable to agriculture. In France, the recourse to external funding, formalized in 2005 by the founding of the National Research Agency (ANR), has also strengthened a logic of desectoralization, encouraging agricultural research to follow the same rules as generalist universities and institutes when seeking funding or undertaking evaluation.

While the identity and activities of agricultural research institutions have been undeniably and extensively influenced by these trends, accusing agricultural research of becoming an ivory tower would, however, be specious. Some dynamics originating from the management of institutes, or the researchers themselves, have indeed helped maintain the link to actors on the ground and the transformative ambition of agricultural research. As an example, we can mention the creation in the 1970s of INRA's Science for Action and Development department (SAD, previously known as Agrarian Systems and Development) to offer a systemic alternative to disciplinary segmentation and opportunities for action- and development-based research (Cornu, 2012). From an international perspective, we can also note the creation in the 1980s of the Agricultural Research Centre for International Development (CIRAD), institutionalizing the existence of agricultural research for development aid in the countries of the Global South. Similarly, once again in the French national context, it is worthwhile mentioning the establishment of financing instruments in the 1990s, such as the Program For and On Regional Development (PSDR, co-funded by INRA and French Regions), aimed at orienting interdisciplinary research to respond to the needs of the local actors. Finally, in the 2000s, structures such as Mixed Technological Networks (RMT) were set up to maintain, or even strengthen, relations between research institutions and actors working for the transformation of the agricultural and agrifood sectors. Thus, as the title of 
this section states, the academic turn taken by agricultural research institutions is part of a diversification of activities and missions, coexisting with various initiatives aimed at maintaining or promoting a high potential for applicability by the farming and rural actors.

\section{New relationships between agriculture, science and society}

In addition to this interpretation of transformations of the techno-scientific world, other levels of analysis that refer to external factors make it possible to diagnose the changes in agricultural research vis-à-vis innovation. The reason agricultural research has changed is because the agricultural world itself has undergone transformations that have made it more difficult for agricultural research to produce innovations. More specifically, the diversification of agricultural production and development models (Lemery, 2003) has contributed strongly to the questioning of the choices made by agricultural research organizations regarding the goals and themes they have favoured thus far and, consequently, has made their task more complicated. Expectations from and new requirements concerning the environment, food quality, or animal welfare, and therefore the new mandates (Hugues, 1996) entrusted by society to agriculture, have upset the existing contractual relationship between the domains of agricultural production and public action in the techno-scientific field. Reflecting this evolution, agricultural research institutions have reshaped themselves to be able to address not only agriculture, but also food and environmental matters. In addition to these trends specific to the agricultural sector, there are tensions pertaining to the more general relationships between science and society, with certain technological innovations inviting strident criticism because of the risks they entail (Beck, 2001). This is especially the case of genetically modified organisms, which have generated particularly strong protests and controversies (Bonneuil et al., 2008), including within the scientific community (Bonneuil, 2006), or technologies such as animal cloning, which have given rise to ethical concerns. In this context of changing relationships between agriculture and society, and between science and society, it is no longer so much the issue of how agricultural research can or must generate innovations for the sake of improved or increased production. Instead, the 
issue concerns the factors that make it possible to identify desirable or legitimate innovations from social, economic, moral and ethical points of view, especially in the context of a growing involvement of non-scientists in making techno-scientific choices. More than the choice of the 'good' technological option or the 'good' innovation between several possibilities, it is increasingly often the challenge of a coexistence of innovations pertaining to contrasting production and development models that is being highlighted (Hubbard and Hassanein, 2013) or, at any rate, that is currently being raised within agricultural research institutions.

\section{Challenging the established division of tasks}

Positioned as it is, at the intersection of dynamics concerning both external actors and protagonists of the scientific world, agricultural research found its role as a designer of technological innovations subject to debate as far back as the 1970s. Indeed, even as agricultural modernization was in full flow, the linear and Fordist model of agricultural innovation was already inviting criticism, especially because of its mainly top-down approach to development and, consequently, of its tendency to ignore the ability of farmers to produce innovations. While some studies even questioned the actual existence of this linear model (Edgerton, 2004), the ability of farmers to be more than mere recipients of innovations conceived in techno-scientific spheres became the cornerstone of a body of engaged literature (Chambers, 1983; Darré, 1999). In this reflection, farmers were also seen to be a source of knowledge and creativity, a fact stressed by authors who were calling the industrial development model into question. The emergence of several alternative agricultural models is thus most often presented as the outcome of the commitment of and experiments conducted by farmers: organic farming (Barres et al., 1985), biodynamic agriculture (McMahon, 2005), and conservation agriculture (Coughenour, 2003) would thus constitute sets of technical innovations developed on the margins of official agricultural research and development systems. Indeed, this is a rather idealistic, or even populist, vision of innovation that is tending to consolidate itself (Thompson and Scoones, 1994), often allied with a sometimes radical criticism of science and technology, despite the fact that in many cases the farmers concerned do not progress alone but do so with support, especially from private operators 
who supply them with inputs and equipment (Goulet, 2011; Goulet and Le Velly, 2013). What finally links these research studies to field dynamics is not any scepticism in the capacity of agricultural research to generate innovations or the relevance of these innovations. It is instead the belief that innovation necessarily originates in techno-scientific circles that is called into question, since the knowledge and experience of the user is considered valuable, as is the case in other fields (von Hippel, 1986).

A significant aspect of this criticism of the linear approach to innovation is that it does not originate only from actors who are on the outside of agricultural research. Many collectives within research institutions themselves are indeed calling for different ways of approaching innovation, challenging, for instance, the traditional boundaries between science and nonscience, between research and development, or between disciplines. This is the case for example in France, within INRA's Science for Action and Development department, already mentioned above, which, since the 1970s, has been promoting systemic and interdisciplinary approaches to innovation and change, and encouraging research practices that are closely tied to action and development (Cornu, 2012). Other research organizations in France, such as CIRAD, are also defending this close link between research and development, understood here in the sense of international cooperation and provision of aid to developing countries. This is also the case in Latin American countries such as Argentina, where research groups were created at the turn of the century around family farming, demanding in a normative perspective a practice of science that is able to support the innovations produced by small farmers and to assist in an evolution towards a fairer society (Goulet, 2016). A more recent facet of these other notions of innovation, challenging the established divides between scientific actors and practitioners or the primacy of agricultural research in the production of innovations, can be observed in the interest expressed recently in open and participatory sciences by institutes such as INRA (Houllier and MerilhouGoudard, 2016). The amateur and user experience no longer opposes that of the scientist, and is even sought specifically for inclusion in knowledge and innovation production activities. Agricultural research thus remains at the heart of the process of the design of innovations, but only within the framework of hybridization in which users and amateurs play an active role, just as they do in other scientific and technological fields (Charvolin et al., 
2007; Demazière et al., 2009; Meyer, 2012).

\section{Agricultural science and research at a time when impact reigns supreme}

The creation of major national agricultural research institutes over 50 years ago was rooted in a context of the primacy of nation-states, and formed part of a modernization project in which science and technology occupied a central role. However, things have changed now. The nation-state no longer occupies a central place in the governance of our societies, or, at the very least, has lost its prominence. Modernization based on the use of chemical inputs and mechanization is no longer considered the sole solution to the challenges facing agricultural sectors both in industrialized as well as emerging or developing countries. While environmental issues have played a key role in the emergence of alternatives in the former, social issues, especially with the institutional consolidation of the family farming category, have done so in the latter (Gisclard and Allaire, 2012). And finally, the forms of governance of techno-sciences have changed considerably (Pestre, 2014), especially regarding the manner in which they are linked to societal and economic issues, and, more specifically, vis-à-vis their contribution to innovation. While techno-scientific activities, in general, have probably never been independent of political or market forces (Pestre, 2003), the recent decades have seen a shift in how their contribution to the increasingly important issues of innovation and change has been perceived and encouraged. It is relevant here to cast a glance at this recent history to understand where exactly is agricultural research situated today in its contemporary forms of existence.

The 1970s and 1980s saw the enlistment of science and technology in a globalized neoliberal economic regime, in which they were used less to promote the development of nation-states than to bolster the competitiveness of countries in the context of international economic competition (Bonneuil and Joly, 2013). The rise of internationalized companies in the race for innovation, the growing importance of intellectual property, and the decline in public funding of research and development activities were key elements of this approach, marked by a withdrawal of the State. Public scientific and 
technical institutions became actors, among others, of national innovation systems that the Organisation for Economic Co-operation and Development (OECD) sought to support in the 1990s (Godin, 2009). While allocations by the State of resources to the scientific sector were designed to raise the performance of countries in the international competition for rankings and scientific discoveries, they also primarily helped reinforce industrial and economic competitiveness through appropriable research and legal and commercial protection of scientific knowledge (Popp Berman, 2012). As far as the management of the scientific sector itself was concerned, the forms of administration relied on the new public management methods to accentuate a shift towards the measurement of individual performance (Bezes et al., 2011), especially in the academic field mentioned above, or towards flexibility and competitiveness for obtaining project funding (Braun, 1998). New services and departments were created within the techno-scientific institutions to promote and organize connections with field actors, especially in the business sector. In French agricultural research institutions, such as INRA (with INRA-Transfert) or CIRAD (with its Technology Transfer and Development Office), programmes and subsidiaries were created in the early 2000 s to transfer research results, to support researchers in their collaboration with the private sector, or even to promote the creation of innovative companies.

More recently, this neoliberal turn is being expressed specifically through a top-down control of scientific activities so that they can contribute to a transformation of the agricultural world that is more attuned to meeting the new societal challenges. Indeed, agricultural research is now part of a strategic science regime (Rip, 2004) in which the governance of technosciences is based both on the pursuit of an objective of academic excellence as well as on the contribution they can make towards finding solutions to the concrete problems confronting societies. To make scientific research more operational or applied in nature, especially to justify its funding in tight budgetary contexts, the major challenges have to first be defined correctly (Foray et al., 2012; Kuhlmann and Rip, 2014). The researchers are then expected to mobilize and demonstrate their ability to find solutions to these challenges for the future. For example, the European Union Horizon 2020 programme and that of the French National Research Agency identify major challenges in the fields of energy, health, food, agriculture, transport and 
climate that researchers are invited to address. In the agricultural field, Wright (2012) has thus highlighted how, in the centres of the CGIARs (Consultative Group on International Agricultural Research), funding is being directed towards major challenges, such as world hunger and increased yields. To choose these challenges, and more precisely the terms that identify them, 'umbrella' concepts (Rip and Voß, 2013) which can address both current social issues and science have to be used. Thus, in the more delimited field of agricultural research institutes, terms such as 'agroecology', 'climatesmart agriculture', 'sustainable agriculture', 'food security' and 'social inclusion' have become veritable and obligatory references for researchers seeking funding and legitimacy. From the outset, the allocation of funds aims to orient the activities of researchers so that they help find solutions to problems defined as 'public' by the political sphere. The term 'innovation' as such is not always present, but the idea of producing a transformative change in society is inherently central to this way of governing science (Weber and Rohracher, 2012). Studies which have specifically examined how these forms of governance of science have or have not led to transformations in research practices remain cautious in their conclusions. They observe most often the researchers' resistance to having their agendas defined by others (Hubert et $a l ., 2012$ ) and the opportunistic strategies adopted to adjust to an increasingly fragmented funding environment (Charlier and Delvenne, 2015). Tighter framing of research and the growing alignment of funding with predefined subjects are often even denounced as being counterproductive, described by some researchers as obstacles to innovation and creativity. But to a large extent, this is the classic ambiguity characterizing the rhetoric of justification by researchers of their activities (Gieryn, 1983), between the claim of a fundamental research and the defence of its potential for application (Calvert, 2006, Di Bello, 2013), which often surfaces in the face of these demands to make science operational.

Although, in most cases, agricultural research has not formed the empirical perimeter addressed by the studies mentioned above, it nonetheless forms part of these dynamics aimed at bringing science closer to society, and, in this case, to the agricultural sector. Joly (2015) has thus highlighted how the activities of researchers from agricultural research institutes, and even elsewhere, is part of a regime of techno-scientific promises, within whose framework the definition and justification of new lines of research depend on 
the potential technological or economic benefits they could generate. Thus, it is the desire to increase the impact of publicly funded research (Gozlan, 2015) that has gradually developed, and which has engendered an intense movement in French agricultural research institutions. Indeed, INRA (Joly et al., 2015), as well as CIRAD, have thus undertaken reflections and methodological studies to qualify and measure the impact of research conducted in institutes. By incorporating the motto 'Science and Impact' into its logo, INRA has even made this concern for the operational results of research activities one of the pillars of its identity, or at least of its communication interface. In this sense, the trajectory of this institute, created in 1946, constitutes in itself a testimony of this old relationship, sometimes tumultuous and currently being reinvented, between agricultural research and innovation.

\section{In conclusion}

So while agricultural research has, since its rise within the framework of nation-states, always been planned and administrated as applied research, aimed at generating knowledge and innovations to support agricultural production, its constituent terms, practices and the actors have evolved considerably and have diversified over time. These research institutes have in fact transformed themselves, in their composition as well as in their activities, by embracing the transversal trends sweeping the scientific world. One of the results of these evolutions has been a loosening, or at least a transformation, of the close ties that had originally been created with the agricultural world and extension workers. Agricultural research, its institutions and its researchers have gradually had to contend with very varied demands, which individuals and organizations have accommodated in different ways. The expectations of the agricultural world have evolved during the same period, developing in some cases a strong criticism of these publicly funded institutions. Furthermore, the major areas around which the missions of agricultural research were planned have also evolved, gradually including, alongside agricultural production - which has itself experienced a major diversification with, for example, the rise of organic farming -, new domains such as food quality, nutrition, and the environment. The nature of the relationship between the agricultural research community and its partners has 
also changed considerably. The culture of transfer to the private sector, just like that of major challenges and of impact, now generally dominates institutes, their scientific policies and researchers. Of course, innovation is not always the keyword that is systematically put forward to apprehend these dynamics, whether by analysts or their protagonists. The terms 'impact', 'social utility', and 'operationalization of science' are often mobilized, and the question can then be asked as to what constitutes innovation or what is related to it. But we have chosen here to apprehend these different terms as concerning the same dynamics, referring to the capacity of scientific activities to transform society or certain productive sectors. It is indeed this latter issue to which we want to draw the reader's attention in this chapter by emphasizing the importance of reflecting not only on the role of agricultural research in the production of innovation, but also on the ways in which innovation is actually conceived within these institutions.

\section{Mibliography}

Barres D., Bonny S., Le Pape Y., Rémy J., 1985. Une éthique de la pratique agricole. Agriculteurs biologiques du Nord-Drôme. Inra, Économie et sociologie rurales, Paris.

Beck U., 2001. La société du risque : sur la voie d'une autre modernité. Éditions Aubier, Paris.

Bezes P., Demazière D., Le Bianic T., Paradeise C., Normand R., Benamouzig D., Pierru F., Evetts J., 2011. New Public Management et professions dans l'État : au-delà des oppositions, quelles recompositions ? Sociologie du travail, 53(3), 293-348.

Bonneuil C., 2006. Cultures épistémiques et engagement public des chercheurs dans la controverse OGM. Natures Sciences Sociétés, 14, 257268.

Bonneuil C., Joly P. B., 2013. Sciences, techniques et société. La Découverte, Paris.

Bonneuil C., Joly P.B., Marris C., 2008. Disentrenching experiment? The 
construction of GM-crop field trials as a social problem in France. Science, Technology and Human Values, 33(2), 201-229.

Bonneuil C., Thomas F., 2009. Gènes, pouvoirs et profits. Recherche publique et régimes de production des savoirs de Mendel aux OGM. FPH, Éditions Quæ, Versailles.

Braun, D., 1998. The Role of Funding Agencies in the Cognitive Development of Science. Research Policy, 27(8), 807-821.

Brunier S., 2015. Le travail des conseillers agricoles entre prescription technique et mobilisation politique (1950-1990). Sociologie du travail, 57, 104-125.

Calvert J., 2006. What's Special about Basic Research? Science, Technology \& Human Values, 31(2), 199-220.

Chambers R., 1983. Rural Developement. Putting the last first. Longman, New-York.

Charlier N., Delvenne P., 2015. Actors valuing science in neoliberal science regimes. Paper presented at Changing Political Economy of Research and Innovation, San Diego, CA, March 2015.

Charvolin F., Micoud A., Nyhart L.K. (eds), 2007. Des sciences citoyennes? La question de l'amateur dans les sciences naturalistes. Éditions de l'Aube, La Tour d'Aigues.

Cornilleau L., Joly P.-B., 2014. La révolution verte, un instrument de gouvernance de la " faim dans le monde ». Une histoire de la recherche agronomique internationale. In: Le gouvernement des technosciences. Gouverner le progrès et ses dégâts depuis 1945 (D. Pestre, ed.), La Découverte, Paris.

Cornu P., 2012. La passion naturaliste. Trois études d'anthropologie historique de la question agraire à l'époque contemporaine. HDR, Université Lumière, Lyon 2. 
Coughenour C.M., 2003. Innovating Conservation Agriculture: The Case of No-Till Cropping. Rural Sociology, 68(2), 278-304.

Coulomb P, Delorme H, Hervieu B, Jollivet M, Lacombe P. (eds), 1990. Les agriculteurs et la politique. Presse Sciences Po, Paris.

Darré J.-P., 1999. La production de connaissances pour l'action. Arguments contre le racisme de l'intelligence. Éditions de la Maison des sciences de l'homme, Paris.

Demazière D., Horn F., Zune F., 2009. Les développeurs de logiciels libres : militants, bénévoles ou professionnels ? In: Sociologie des groupes professionnels. Acquis récents et nouveaux défis (D. Demazière and C. Gadéa, eds), La Découverte, Paris, 285-295.

Di Bello M.E., 2013. Investigadores academicos, conocimientos cientificos y utilidad social. REDES, 19(36), 51-78.

Edgerton D., 2004. 'The linear model' did not exist: Reflections on the history and historiography of science and research in industry in the Twentieth Century. In: The Science-Industry Nexus: History, Policy, Implications (K. Grandin, N. Wormbs, S. Widmalm, eds), Science History Publications, Sagamore Beach, MA, 31-57.

Foray D., Mowery D.C., Nelson R.R., 2012. Public R\&D and social challenges: What lessons from mission R\&D programs? Research Policy, 41, 1697-1702.

Gieryn T.F., 1983. Boundary-Work and the Demarcation of Science from Non-Science: Strains and Interests in Professional Ideologies of Scientists. American Sociological Review, 48(6), 781-795.

Gingras Y., 2014. Les dérives de l'évaluation de la recherche. Du bon usage de la bibliométrie. Éditions Raisons d'agir, Paris.

Gisclard M., Allaire G., 2012. L'institutionnalisation de l'agriculture familiale en Argentine : vers la reformulation d'un référentiel de développement rural. Autrepart, 62, 201-216. 
Godin B., 2009. National Innovation System. The System Approach in Historical Perspective. Science, Technology \& Human Values, 34(4), 476501.

Goulet F., 2011. Firmes de l'agrofourniture et innovations en grandes cultures : pluralité des registres d'action. Pour, 212, 101-106.

Goulet F., 2016. Faire science à part. Politiques d'inclusion sociale et recherche agronomique en Argentine. HDR, université Paris-Est.

Goulet F., Le Velly R., 2013. Comment vendre un bien incertain ? Activités de détachement d'attachement d'une firme d'agrofourniture. Sociologie $d u$ travail, 55(3), 369-386.

Gozlan C., 2015. L'autonomie de la recherche scientifique en débats : évaluer l' « impact » social de la science ? Sociologie du travail, 57(2), 151-274.

Houllier F., Merilhou-Goudard, J.-B (eds), 2016. Les sciences participatives en France. États des lieux, bonnes pratiques et recommandations, 63 p., DOI: $10.15454 / 1.4606201248693647 \mathrm{E} 12,<\underline{\text { https://inra-dam-front-resources- }}$ cdn.brainsonic.com/ressources/afile/320323-7bb62-resource-rapport-de-lamission-sciences-participatives-fevrier-2016.html $\quad$ r> $\quad$ (retrieved 17 July 2018).

Hubbard K., Hassanein N., 2013. Confronting coexistence in the United States: organic agriculture, genetic engineering, and the case of Roundup Ready alfalfa. Agriculture and Human Values, 30, 325-335.

Hubert M., Chateauraynaud F., Fourniau J.M., 2012. Les chercheurs et la programmation de la recherche : du discours stratégique à la construction de sens. Quaderni, 77, 85-96.

Hugues E.-C., 1996. Le regard sociologique. Essais choisis. EHESS, Paris.

Joly P.-B., 2015. Le régime des promesses technoscientifiques. In: Sciences et technologies émergentes : pourquoi tant de promesses? (M. Audétat, ed.), Hermann, Paris. 
Joly P.-B., Colinet L., Gaunan A., Lemarié S., Larédo P., Matt M., 2015. Évaluer l'impact sociétal de la recherche pour apprendre à le gérer : l'approche ASIRPA et l'exemple de la recherche agronomique. Gérer \& Comprendre, 122, 31-42.

Kloppenburg J.R., 2004. First the seed. The University of Wisconsin Press, Madison, WI.

Kuhlmann S., Rip A., 2014. The challenge of addressing Grand Challenges. A think piece on how innovation can be driven towards the "Grand Challenges" as defined under the prospective European Union Framework Programme Horizon 2020. European Research and Innovation Area Board (ERIAB), $11 \mathrm{p}$.

Lemery B., 2003. Les agriculteurs dans la fabrique d'une nouvelle agriculture. Sociologie du travail, 45(1), 9-25.

McMahon N., 2005. Biodynamic Farmers in Ireland. Transforming Society Through Purity, Solitude and Bearing Witness? Sociologia Ruralis, 45(1-2), 98-114.

Meyer M., 2012. Bricoler, domestiquer et contourner la science : l'essor de la biologie de garage. Réseaux, 173-174, 303-328.

Payre R., Pollet G., 2013. Socio-histoire de l'action publique. La Découverte, Paris.

Pestre D. (ed.), 2014. Le gouvernement des technosciences. La Découverte, Paris.

Pestre D., 2003. Science, argent et politique. Un essai d'interprétation. Inra Éditions, Paris.

Popp Berman E., 2012. Creating the Market University: How Academic Science Became an Economic Engine. Princeton University Press, Princeton, NJ.

Rémy J., 1987. La crise de la professionnalisation en agriculture : les enjeux 
de la lutte pour le contrôle du titre d'agriculteur. Sociologie du travail, 29(4), 415-441.

Rip A., 2004. Strategic Research, Post-modern Universities and Research Training. Higher Education Policy, 17, 153-166.

Rip A., Voß J.P., 2013. Umbrella Terms as Mediators in the Governance of Emerging Science and Technology. Science, Technology \& Innovation Studies, 9(2), 39-59.

Thompson J., Scoones I., 1994. Challenging The Populist Perspective: Rural People's Knowledge, Agricultural Research, and Extension Practice. Agriculture and Human Values, 11, 58-76.

Von Hippel E., 1986. Lead users: a source of novel product concepts. Management Science, 32(7), 791-805.

Weber K.M., Rohracher H., 2012. Legitimizing research, technology and innovation policies for transformative change. Combining insights from innovation systems and multi-level perspective in a comprehensive 'failures' framework. Research Policy, 41, 1037-1047.

Wright B.D., 2012. Grand missions of agricultural innovation. Research Policy, 41, 1716-1728.

5In 2014, a major innovation of agronomic research in monoculture banana plantations in the West Indies consisted of the reintroduction of the practice of fallow!

6In France, the term 'Les Trente Glorieuses' (Thirty Glorious Years) refers to the 30-year period (1945 to 1975) following the Second World War which saw strong and rapid economic growth in France and other developed countries.

7The international centres of agricultural research at the origin of the Green Revolution were created in the 1970s.

8It is interesting to note that this is the same situation that is currently found in some Asian and African countries and risks becoming more widespread in the coming decades.

9In this book, the terms 'sustainable' and 'sustainability' will be used in a restricted sense to characterize a process, a system, or a sector of activity, among others, which are developed and function with respect for sustainable development ('development that meets the needs of the present without compromising the ability of future generations to meet their own needs,' as defined by the 1987 United Nations Brundtland Commission). 
10The concept of path dependence conveys the idea that innovation and business performance are determined by past routines and technologies.

11School of thought also called 'sociology of science and technology', 'translation sociology' or even 'actor-network theory' depending on the authors and objects under study.

12Precision agriculture aims at optimizing the use of inputs and adapting farming practices by taking intra-plot variability into account in order to obtain optimal yields.

13Let us note, however, the continued existence of the Société française d'économie rurale (French Society of Rural Economics) which, despite its name, accords an important place to the pluralism of disciplines and approaches in the social sciences. 


\section{Part 2}

\section{Forms of innovation in agriculture and the food sector}

\section{Chapter 4}

\section{Agroecological innovation: mobilizing ecological processes in agrosystems}

\section{StÉPhane De TourdonNet AND HÉLÈne Brives}

Summary. To meet the myriad challenges confronting agriculture, the agroecology proposes designing agricultural systems that leverage ecological processes. This requires the mobilization of nature-objects, often not very pliable and which are able to build a multitude of links with other agrosystem elements. It is these inherent characteristics that make agroecology a specific process of innovation, leading to a revamping of approaches and of support and advisory mechanisms destined for farmers.

Around the world, under-nutrition's coexistence with over-nutrition, product health standards and environmental protection requirements, greenhouse gas emission reduction targets, and price volatility of agricultural products and inputs are generating new societal, environmental and economic concerns that are calling into question the agricultural development models inherited from the era of agricultural modernization. Faced with these challenges, agriculture must adapt and innovate. Agroecology, based on agricultural and food systems that leverage ecological processes (recycling of elements, nitrogen fixation by legumes, creation of soil porosity by earthworms, or predation of crop pests, for example), appears as an alternative solution to 
respond to several different issues:

- feeding a growing population, through the design of sustainable and resilient production systems, the use of techniques to maintain fertility in situations of low input use (for reasons of poverty, conscious choice or environmental impact), and the design of more sustainable and equitable new food systems, (combination of crops and livestock, short supply chains, etc.); - reducing environmental impacts, providing ecosystem services (such as carbon storage in soils, pollination, and regulation of water flows) and coping with climate change through agricultural systems based on increasing biodiversity, reuse of organic matter and looping of nutrient cycles;

- coping with the depletion of certain resources (energy, fertilizer, etc.) and with health risks (caused by phytosanitary products, for example) by replacing chemical inputs with the agrosystem's ecological functionalities.

Several authors have shown that basing the design of agricultural systems on ecological functionalities requires new knowledge, a holistic approach spanning different spatial scales, and innovative design mechanisms based on a combination of scientific, technical, and operational knowledge (Altieri, 1995; Francis et al., 2003; Gliessman, 2006; Warner, 2007). The agroecological transition therefore appears to be a complex innovation process, one in which technical changes of agroecological origin are inseparable from changes in food, social, economic, institutional and political systems. While this complexity can be found in all agricultural transitions, does recourse to agroecology entail specific innovation processes? The objective of this chapter is to answer this question, starting from what is at the core of all agroecological approaches, i.e. the mobilization of ecological processes present in the agroecosystem, in order to draw lessons from them on how to support and foster agroecological innovation.

\section{Agroecological approaches}

Agroecology's emergence over time has been a complex process and has led to many debates between scientific disciplines, between social movements, and between proponents of different alternative agricultural systems. However, it is this very combination of scientific, social and technical dimensions that constitutes agroecology's richness (Wezel et al., 2009; 
Tomich et al., 2011, Stassart et al., 2013). The objective of this chapter is not to describe the innovation processes at work - given the vast diversity of agroecological approaches - but instead to focus on what constitutes its originality and specificity in comparison to other forms of innovation. According to us, the very principle of agroecology, given the characteristics of living organisms and the biological processes that underlie it, confers a certain specificity to agroecological innovation. The sociology of science and technology encourages us to take these nature-objects seriously, in order to understand in particular the framework of action they belong to, as well as the relationships (or linkages) they are part of (Latour, 2000; Hennion, 2013).

Agroecology can be implemented according to two different approaches, which some authors distinguish between 'strong' agroecology and 'weak' agroecology (Duru et al., 2015a).

The first approach (strong agroecology) corresponds to the original notion of agroecology. It is based on the reintroduction of different forms of diversity (biodiversity, diversity of practices, diversity of knowledge and actors) in agrosystems in order to identify and use the levers necessary for managing and amplifying ecological processes. This can be achieved by decreasing disturbances (e.g. no longer tilling the soil) or increasing crop biodiversity (e.g. introducing service plants on or around the plot). This often leads to disruptive agricultural systems, involving a different functioning of the agrosystem, and thus to specific learning requirements to be able to manage it, a change in the system of knowledge production, and adaptive behaviour on the part of the producers (Girard, 2014).

The second approach (weak agroecology) consists of creating biotechnologies inspired by ecological processes, so as to amplify them. This can be achieved by modifying the living organisms that undertake these processes (for example, to obtain fungi that are more effective for mycorrhization) or by acting directly on the process (for example, to produce biostimulants of natural plant defences). This approach does not generally lead to disruptions in the way of managing the agroecosystem since the farmer activates ecological processes using conventional techniques. It is, however, controversial, as it is considered by the proponents of the first approach as a simple 'greening' of conventional agriculture through the use 
of certain biotechnologies, without any reference to agroecology's founding principles.

These two forms are not necessarily incompatible (Duru et al., 2015b) even though they refer to two contradictory paradigmatic images: the first is based on the re-naturalization of agricultural and food systems, while the second relies on biotechnological capabilities to meet the needs of societies. Their respective implementations can lead to radically different postures in the way of thinking about innovation (biotechnology vs farmer innovation), the relationship with nature (controlling $v s$ hands-off), or the relation to knowledge (capitalizing vs co-building) (Girard, 2014; Javelle, 2016; Javelle et al., 2016).

\section{Woes recourse to agroecology lead to specific or original innovation processes?}

In this diversity of approaches to agroecology, its operational implementation raises a key question: How to mobilize the organisms that underpin the ecological processes that we would like to activate? From an agronomist or farmer viewpoint, these living organisms exhibit some flaws when we seek to mobilize and incorporate them into agricultural systems. We can distinguish five such flaws.

First, these organisms are often little known in the context of the cultivated field, a situation that stems from the fact that agronomy has, for some time now, moved away from the study of the biological component and, during the same period, ecology has drifted away from the study of agrosystems (Chevassus-au-Louis, 2006). Building scientific knowledge of these biological objects is therefore a key issue for the research community, but the challenge is also to take advantage of the secular knowledge that exists of these objects, especially in the forms of agriculture in which there still exists a high level of biodiversity in cultivated systems, now found mainly in the Global South (Altieri and Toledo, 2011). It is therefore necessary to hybridize scientific knowledge with operational knowledge and expert knowledge, so that they can together lead to transformations in farmers' practices and agricultural systems (Girard, 2014). The construction of the necessary 
knowledge must therefore be based not only on scientific work, but also on mechanisms of co-design and participatory research (Warner, 2008; Meynard et al., 2012; Berthet et al., 2015).

Second, living organisms are sensitive to the environment and practices. A technological artefact, on the other hand, owes in part its large-scale success to the fact that its use is decontextualized, i.e. insensitive to the context, which makes it possible to include it in a standard technical package, easier to implement, and thus to disseminate. Living organisms often resist similar inclusion in a technical package, as they maintain many relationships critical to their very existence with the environment around them, thus making them very sensitive to context. And since each process is unique, universal recipes cannot simply be applied. It is necessary, of course, to have generic knowledge, but the actors must also build situated knowledge, put in place specific modes of learning, based in particular on the ability to decontextualize and then re-contextualize (Brives and de Tourdonnet, 2010; Brives et al., 2015).

Third, living organisms are sometimes difficult to control (Figure 4.1) because their numbers and activity respond to ecological processes that are hard to manage (population dynamics, among others). For example, a cover plant may not grow well or, on the contrary, grow too abundantly, or a drought may put a stop to earthworm activity. This control can be achieved or attempted through direct management of the organism concerned (for example, by controlling the date of planting and density of a cover crop), but most often, habitat management is involved (by planting cover crops that promote earthworm activity, for example). These indirect management methods, which can find inspiration in integrated protection and biological control through habitat management, are based on a detailed knowledge of the spatial and temporal dynamics of ecological processes. They can often lead to effects that overflow the scale of the plot to outside the field's boundaries and, even further, to the landscape as a whole (Baudry, 1993; Francis, 2003). 


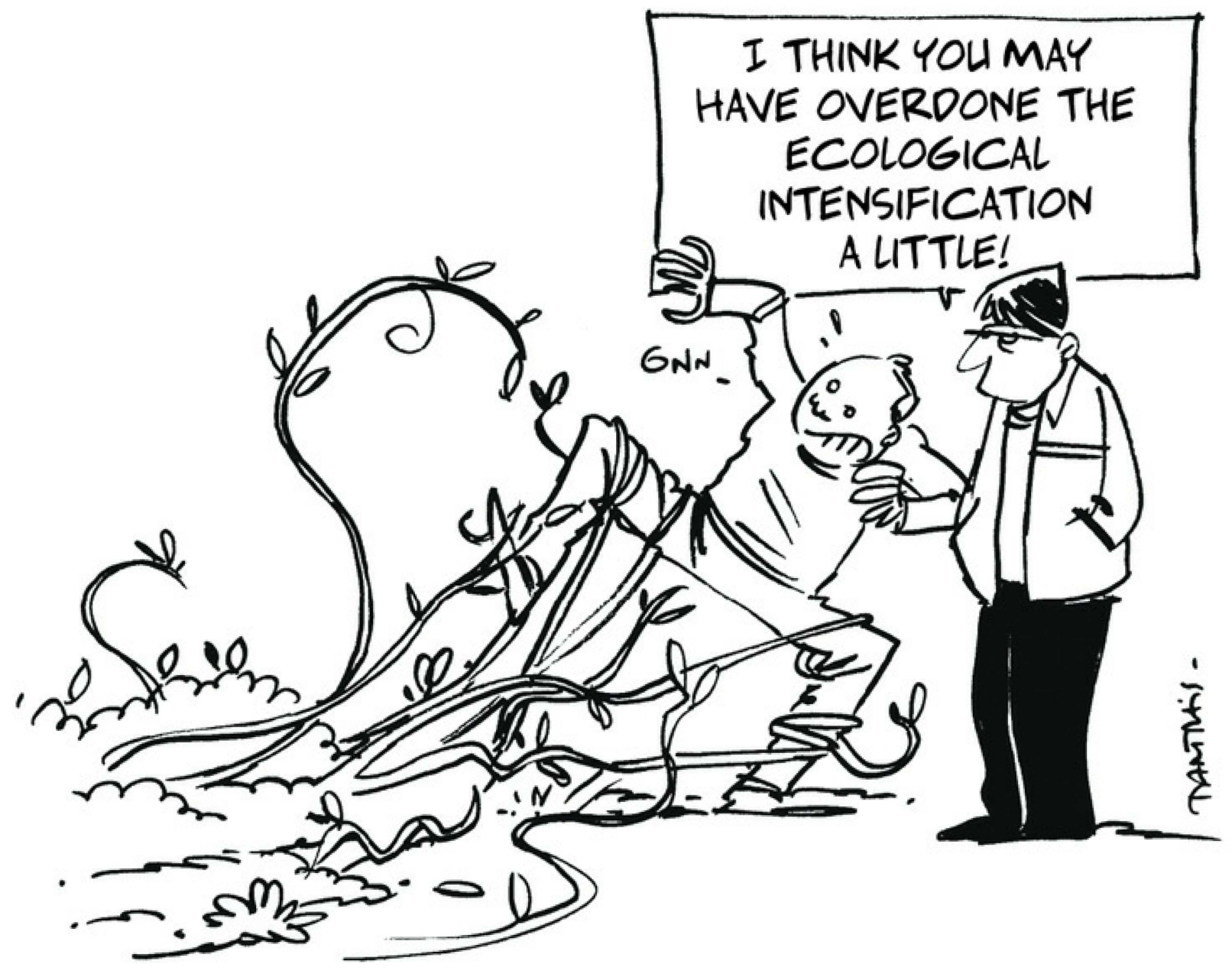

Figure 4.1. A humorous illustration of an organism mobilized in an agroecological system and which has escaped all control (Goulet, 2012) (c) Erik Tartrais

Fourth, organisms mobilized for agroecology sometimes have unintended effects because their interactions with the ecosystem are not limited to the functions for which they have been mobilized. A cover plant sown to choke weeds may become a weed itself if left to seed or may become a pathogen host (Carof et al., 2007). It is necessary to be able to identify and sometimes counteract these effects, so that the service expected from the organism does not become counterproductively damaging. Risk management thus becomes a key element of agroecological innovation.

Finally, the effects of the mobilized organisms are often not very visible or are perceived too late. How can the symbiotic fixation of a cover legume or 
the porosity created by earthworms be evaluated, for example? The mobilization of organisms therefore requires the development of methods to observe and assess their effects in relation to the agrosystem's functioning and the expected benefits. This type of method, developed for example in the context of integrated protection, is often not available when it comes to soil organisms (Blanchart et al., 2005; Scopel et al., 2013; Hellec et al., 2015). The challenge is to find indicators and modes of perceiving the essential functions provided by the organisms of interest within the agrosystem.

Thus, the characteristics of biological organisms mobilized in a process of transition to agroecology contrast with those of modern artefacts of agriculture, i.e. agricultural equipment, pesticides and synthetic fertilizers. Their behaviour remains, above all, unpredictable. Their activity is difficult to contain in a framework (Callon, 1999); they require continuous monitoring and the ability to react to their overflows, which always remain possible.

These nature-objects are what Latour (1997) calls 'hairy' objects, because they have the ability to associate with a multiplicity of other objects and thus to exit the frameworks that had been expected of their activity. This 'hairy' aspect and this multiplicity of associations will generate new sources of questions, learning and actions. Thus, for example, a farmer using a cover plant for a few years as a nitrate trap can also discover this plant's effects on the soil structure and become interested in the activity of earthworms in his plots, then potentially reduce tilling or plant other cover plants to boost the earthworms' activity (de Tourdonnet et al., 2013). Many farmers who change their attitude as a result of engaging in an agroecological innovation process state that they have 'become researchers', that they have rediscovered 'agronomy'.

This research attitude of the various actors marks the specificity of agroecological innovation. Unlike the implementation of modern objects, which presupposes a separation between their designers and their users (Hennion, 2013), that of the objects of agroecology is a privileged moment of knowledge production involving them. The distinction of roles between farmers and the scientists or technicians supporting them thus becomes blurred and reconfigured. 


\section{How to support agroecological innovation?}

The changes in attitude, vision and paradigm required by a shift to agroecology calls for a suitable adaptation of the methods and the mechanisms of providing agricultural advice. The posture adopted in providing support plays a decisive role in the process of agroecological innovation and in the socio-technical systems it leads to. An apt illustrative example (de Tourdonnet et al., 2013; Brives et al., 2015) is the comparison of two very different advisory mechanisms intended to support the adoption and implementation of conservation agriculture[14], which can be part of an agroecological approach, within the same agricultural cooperative.

- The first mechanism consists of directed and prescriptive advice to accompany the farmers in adopting direct seeding, by completely eliminating tillage. The adviser, as expert, prescribes procedures to follow for a rapid transition to direct seeding and expects the farmer to apply them to the letter to ensure a successful transition. It is therefore the adviser who bears a large part of the risk, which leads him to recommend a standardized solution, in which the fight against weeds is systematically undertake with glyphosate. The use of cover plants, an agroecological alternative to herbicide application, is not considered at all because the knowledge on how to manage this approach is not sufficiently stabilized and is too context-sensitive to be implemented through a risk-free prescriptive mechanism.

- The second mechanism consists of non-prescriptive learning support, originating from collective advice in which each member of the group advances in his own way. The adviser is in the position of a peer, engaged in learning, and in the position of a coordinator of an agroecological approach, in which weeds are managed through a reflection on crop rotation and the introduction of cover plants. This collective reflection leads each farmer to design and test these technical solutions by himself and to discuss the results he obtains within the group.

The first mechanism may appear to be more efficient because, using a radical innovation, it allows a rapid transition to direct seeding, whereas the second leads to a slower, step-by-step transition to a variety of systems (occasional no-till, reduced tillage, direct seeding under cover, etc.) However, the first mechanism creates two strong attachments on the part of the farmer: to the adviser and to the glyphosate. The second, on the other hand, creates an 
attachment to the capacity of the group (or other groups) to construct knowledge suitable for solving problems. This example shows that to support agroecological innovation, it is very important to identify the attachments (or dependencies) that can be created, some more desirable than others, when undertaking an agroecological transition.

The prescriptive approach (in which there is a one-to-one correlation between a problem and a solution) often seems unsuitable for providing advice on agroecology, and this for two main reasons:

- there often exists not one but several solutions to a problem, depending on the biophysical and ecological context, locally available knowledge, and the farmer's capabilities and accumulated expertise;

- the problem must be repositioned in a holistic approach in order to be able to rely on ecological processes, identify the levers of action, and anticipate the consequences.

That said, everything depends on what is prescribed, according to whether it is ready-to-use technical solutions or knowledge and methods to build technical solutions adapted to each particular case. While the first mechanism's approach is too normative for an agroecological transition, there is no doubt that it generates results more quickly for a larger number of farmers. And even though the second mechanism's approach can promote the construction and the transfer of instruments that are very useful for an agroecological transition (guides, experiments, data/fact sheets, etc.), it requires more time and therefore risks benefiting fewer farmers. These instruments make it possible to formalize knowledge, to make it accessible and actionable, which is a key challenge for agroecology. As many authors have shown (Uphoff, 2001; Warner, 2008; Brives et al., 2015), these instruments are much more effective if they are designed and used in participatory forms of intervention or support involving agricultural producers.

The example also illustrates the importance of managing the uncertainties while accompanying any agroecological innovation, whether they arise from unstabilized solutions, incomplete knowledge, the difficulties in assimilating or learning new ways of doing things, or agronomic and economic risks. A change in the type of management of the agroecological transition to address 
these uncertainties is often observed (Girard, 2014). Optimal control gives way to adaptive management, defined as an iterative process aimed at reducing uncertainty over time through constant monitoring of the system. Accompanying and supporting this process requires taking the knowledge produced by the on-site practitioners into account in order to design tools and learning-in-action situations. These learnings strengthen the capacity of the practitioners: improved ability to observe changes in the environment, to interpret them, to identify and activate the levers that can orient these changes, and to assess their impacts. Advising and encouraging adaptive behaviour involves placing the farmer in a position of co-designer and coevaluator, offering a library of innovations rather than a turnkey system (Meynard et al., 2012), and learning to let nature do its best and to manage one's concerns (Javelle, 2016).

In the end, the key challenge in supporting agroecological innovation lies in the ability to support the farmers in their role of researchers. To do so, it is a matter of:

- managing uncertainties arising from ecological processes, while respecting the right of each actor to accept the level of risk he feels comfortable with;

- facilitating knowledge production processes, by organizing forums to share experiences and to present, compare and pool expertise from various sources; - introducing, in a systematic way, questions on the functional processes underpinning the behaviours of the objects observed and a holistic approach to the interactions between the objects;

- encouraging the exploration of new objects and of the effects of their interactions during the innovation process.

\section{W Conclusion: agroecology forces a revamp of agronomy as well as of support and accompaniment}

The fundamental originality of agroecological innovation stems from the characteristics of the objects on which it is based. Mobilizing living organisms in agrosystems leads to a focus on nature-objects. The foundations of agroecology - the holistic, participatory and situated approach; the hybridization of knowledge; and risk management - derive from the specific 
characteristics of these nature-objects that we seek to use as technical levers.

This leads to shifts in the field of agronomy and in the relationship between man, technology and nature. The mobilization of nature-objects does not mean the abandonment of all technical objects and disconnection from the upstream industrial or artisanal world. In some cases, this connection is, on the contrary, reinforced, when new artefacts are needed for this mobilization (a direct seeding drill, for example, to no longer disturb the soil) or when nature-objects are 'manufactured' (cover plants selectively bred to provide certain services, for example). Not only the workings of nature, but also the visions of the relationships between man and nature and between man and machine are essential to understand and accompany the process of innovation.

This also influences the way support has to be provided to agroecological innovation. It has, in particular, to strengthen the capacity of the actors of this form of innovation to be able to experiment and design solutions by themselves. To this end, it is essential to take the disruptions induced by this form of innovation into account. These breaks can pertain to the knowledge production system (way of ascribing meaning to singularities and hybridizing knowledge from different sources), the frameworks of thought and action which structure the individual and collective learnings, the agrosystem's functioning and management (perception of processes and taking of risks into account), or social relationships built on knowledge production (between scientists, technicians and farmers). Increasing collective capacities to design alternative systems and adapted support systems is without doubt one of the biggest challenges of agroecological innovation and calls for the revamping of mechanisms of providing support and advice to farmers.

\section{Wibliography}

Altieri M.A., 1995. Agroecology: the science of sustainable agriculture, Westview Press, Boulder, Colorado. 433 p.

Altieri M.A., Toledo V.M., 2011. The agroecological revolution in Latin America: rescuing nature, ensuring food sovereignty and empowering 
peasants. Journal of Peasant Studies, 38(3), 587-612.

Baudry J., 1993. Landscape dynamics and farming systems: problems of relating patterns and predicting ecological changes. In: Landscape ecology and agroecosystems (R.G.H. Bunce, L. Ryzkowski, M.G. Paoletti, eds), Lewis publishers.

Berthet E.T.A., Barnaud C., Girard N., Labatut J., Martin G., 2015. How to foster agroecological innovations? A comparison of participatory design methods. Journal of Environmental Planning and Management, 1-22, doi:10.1080/09640568.2015.1009627 조.

Blanchart E., Brown G.G., Chernyanskii S.S., Deleporte P., Feller C., Goulet F., 2005. Perception et popularité des vers de terre avant et après Darwin. Étude et gestion des sols, 12(2), 145-152.

Brives H., de Tourdonnet S., 2010. How can community-based knowledge be exported? The example of an intervention study carried out within a group employing no-tillage techniques, In: Proceedings of the symposium Innovation and Sustainable Development in Agriculture and Food, 28 June 2 July 2010, Montpellier, France.

Brives H., Riousset P., de Tourdonnet S., 2015. Quelles modalités de conseil pour l'accompagnement vers des pratiques agricoles plus écologiques ? Le cas de l'agriculture de conservation, In: Opérateurs du conseil privé en agriculture (C. Compagnone, F. Goulet, P. Labarthe, eds), Educagri, Dijon.

Callon M., 1999. La sociologie peut-elle enrichir l'analyse économique des externalités ? Essai sur la notion de cadrage-débordement, In: Innovations et performances (D. Foray, J. Mairesse, eds), Éditions de l'EHESS, Paris, 399431.

Carof M., de Tourdonnet S., Saulas P., Le Floch D., Roger-Estrade J., 2007. Undersowing wheat with different living mulches in a no-till system (I): yield analysis. Agronomy for Sustainable Development, 27, 347-356.

Chevassus-au-Louis B., 2006. Refonder la recherche agronomique : leçons $\mathrm{du}$ passé, enjeux du siècle. In: Leçon inaugurale du groupe ESA, 
27 September 2006, Angers.

de Tourdonnet S., Brives H., Denis M., Omon B., Thomas F., 2013. Accompagner le changement en agriculture : du non-labour à l'agriculture de conservation. Agriculture, Environnement et Sociétés, 3(2), 19-28.

Duru M., Therond O., Fares M.H., 2015a. Designing agroecological transitions. A review. Agronomy for Sustainable Development, 35(4), 12371257.

Duru M., Therond O., Martin G., Martin-Clouaire R., Magne M.-A., Justes E., Journet E.-P., Aubertot J.-N., Savary S., Bergez J.-E., Sarthou J.-P., 2015b. How to implement biodiversity-based agriculture to enhance ecosystem services: a review. Agronomy for Sustainable Development, 35(4), $1259-1281$.

Francis C., Lieblein G., Gliessman S., Breland T. A., Creamer N., Harwood R., Salomonsson L., Helenius J., Rickerl D., Salvador R., Wiedenhoeft M., Simmons S., Allen P., Altieri M.A. Flora C., Poincelot R., 2003. Agroecology: The Ecology of Food Systems. Journal of Sustainable Agriculture, 22(3), 99-118.

Francis C.A., 2003. Advances in the design of resource-efficient cropping systems. Journal of Crop Production, 8(1/2), 15-32.

Girard N., 2014. Quels sont les nouveaux enjeux de gestion des connaissances ? L'exemple de la transition écologique des systèmes agricoles. Revue internationale de psychosociologie et de gestion des comportements organisationnels, XIX(1), 51-78.

Gliessman S., 2006. Agroecology: the ecology of sustainable food systems, Second Edition, CRC Press. 408 p.

Goulet F., 2012. La notion d'intensification écologique et son succès auprès d'un certain monde agricole français : une radiographie critique. Courrier de l'environnement de l'Inra, 62, 19-29.

Hellec F., Brives H., Blanchart E., Deverre C., Garnier P., Payet V., Peigné J., 
Recou S., de Tourdonnet S., Vian J.-F., 2015. L'évolution des sciences du sol face à l'émergence de la notion de service écosystémique. Résultats d'une étude lexicométrique. Étude et Gestion des Sols, 22, 101-115.

Hennion A., 2013. Vous avez dit attachements ? In: Débordements : Mélanges offerts à Michel Callon (M. Akrich, Y. Barthe, F. Muniesa, P. Mustar, eds), Paris, Presses des Mines, Paris, 179-190.

Javelle A., 2016. Les relations homme-nature dans la transition agroécologique. L'Harmattan, $234 \mathrm{p}$.

Javelle A., Jouven M., de Tourdonnet S., 2016. L'agroécologie interroge les pratiques agricoles. Enjeux autour de la construction et de la transmission des savoirs. In: L'agroécologie : du nouveau pour le pastoralisme? Association française de pastoralisme, Montpellier, 27-35.

Latour B., 1997. Nous n'avons jamais été modernes. Essai d'anthropologie symétrique. La Découverte, Paris, 206 p.

Latour B., 2000. Factures / fractures. De la notion de réseau à celle d'attachement. In: Ce qui nous relie (A. Micoud, M. Peroni, eds), Éditions de l'Aube, La Tour d'Aigues, 189-208.

Meynard J.M., Dedieu B., Bos A.P., 2012. Re-design and co-design of farming systems. An overview of methods and practices. In: Farming Systems Research into the 21 $1^{\text {st }}$ century: The new dynamic (I. Darnhofer, D. Gibbon, B. Dedieu, eds), Springer, 407-432.

Scopel E., Triomphe B., Affholder F., Macena da Silva F. A., Corbeels M., Valadares Xavier J.H., Lahmar R., Recous S., Bernoux M., Blanchart E., Mendes I., de Tourdonnet S., 2013. Conservation agriculture cropping systems in temperate and tropical conditions, performances and impacts. A review. Agronomy for Sustainable Development, 33(1), 113-130.

Stassart P.M., Baret P., Grégoire J.-C., Hance T., Mormont M., Reheul D., Stilmant D., Vanloqueren G., Visser M., 2013. L'agroécologie : trajectoire et potentiel pour une transition vers des systèmes alimentaires durables. In: Agroécologie entre pratiques et sciences sociales (Van Dam D., Nizet J., 
Streith M., Stassart P.M., eds), Educagri édition, Dijon, 309 p.

Tomich T.P., Brodt S., Ferris H., Galt R., Horwath W.R., Kebreab E., Leveau J.H.J., Liptzin D., Lubell M., Merel P., Michelmore R., Rosenstock T., Scow K., Six J., Williams N., Yang L., 2011. Agroecology: A Review from a Global-Change Perspective. Annual Review of Environment and Resources, 36(1), 193-222.

Uphoff N., 2001. Agroecological innovations: increasing food production with participatory development. Routledge, $328 \mathrm{p}$.

Warner K.D., 2007. Agroecology in action. Extending alternative agriculture through social networks. The MIT Press, Cambridge, 273 p.

Warner K.D., 2008. Agroecology as participatory science. Emerging alternatives to technology transfer extension practice. Science Technology Human Values, 33, 754-777.

Wezel A., Bellon S., Doré T., Francis C., Vallod D., David C., 2009. Agroecology as a science, a movement and a practice. A review. Agronomy for Sustainable Development, 29(4), 503-515.

\section{Chapter 5}

\section{Social innovation through short food supply chains: between networks and individualities[15]}

\section{Yuna Chiffoleau and Dominique Paturel}

Summary. Even though ignored for the most part by the literature on social innovation, the food sector is illustrative of a profusion of innovative approaches aimed 
at responding, in new ways, to its various problems. In this chapter, we combine the contributions of the new economic sociology and of the ethic of care in order to analyse two examples of social innovations that rely on short food supply chains to facilitate access to good quality food by people in vulnerable situations. Social innovation is then understood as a relationship-based and contextualized process, built over time by singular individuals, and supported by mediation resources. In line with work on the theory of transitions, our approach allows us to determine the conditions conducive to the emergence of innovative niches as well as to explore the various mechanisms that can help scale an innovation.

'It is not a crisis, it is a real change of the world.' For the philosopher Michel Serres, writing in 2012, the movements that were rattling contemporary societies went well beyond the sole economic crisis. The multiplicity of crises - climate change, depletion of resources, increasing inequalities, identity crises, disruptions brought about by the digital revolution -, coupled with profound changes, was a matter of deep concern (Serres, 2014). Would it be an opportunity to take a relook at the ways of conceiving and apprehending innovation? For some, this context reinforced the interest in technological innovation, seen as a miracle solution, a harbinger of growth. For others who were critics of technical progress, innovation evoked unprecedented interest through the recognition of new forms and purposes represented in the concept of social innovation. In European economic policy, social innovation is defined as a new response to socio-economic problems and to social needs that are not or very inadequately met by markets and public policies (BEPA, 2011). In this case, solutions are built in a participatory manner and sometimes lead, expectedly or unexpectedly, to social transformation (Klein et al., 2017).

Even though ignored for the most part by the scientific literature on social innovation, the food sector is host to a profusion of innovative approaches aimed at responding in new ways to its various problems. Food remains a stark marker of social inequalities. Indeed, many studies have demonstrated a high correlation between a low level of economic resources and food-related health problems (Caillavet et al., 2006). For many institutions and researchers, it is therefore a matter of finding ways to promote healthier food habits among people with limited budgets or who are in vulnerable situations. For a growing number of actors, however, the problem is the difficulty in obtaining good quality food rather than unhealthy consumption behaviours (Celavar and Inra, 2010). Several innovative initiatives have thus emerged in 
recent years in various territories to allow these people, through short food supply chains and participatory approaches, to obtain good quality food products at prices commensurate with their resources.

This chapter is based on two initiatives along these lines and which we analyse as social innovations. More broadly, our analysis aims to produce knowledge on these new forms and rationales of innovation. We take recourse to the new economic sociology and enrich it by the ethic of care (Tronto, 1993) to apprehend social innovation as a relationship-based and contextualized process, built over time by singular individuals and supported by mediation resources.

In the first part of this chapter, we revisit the notion of social innovation, highlighting the three major ways it is conceived of today, which are illustrated in the food sector. We then present the main theoretical and methodological challenges raised by the emergence of social innovation and show how the new economic sociology, combined with the ethic of care, can help meet these challenges. In the second part, we test our analytical framework, between networks and care, on two innovative initiatives to make good quality food available to all. In the third part, we explore the benefits of a dynamic and contextualized approach to innovation, which combines the monitoring of relationships and the taking of people into account, by calling for an in-depth examination of the conditions necessary for the scaling of social innovations.

\section{Questions raised by social innovation regarding the framework of interpretation}

\section{Three conceptions of social innovation, illustrated in the food sector}

Innovation covers a wide range of practices and yet it is often considered solely from the perspective of technological innovation: new products or production processes or new processing techniques, supposedly more 
efficient than existing ones. Furthermore, innovation is often thought of as the domain of companies or entrepreneurs endowed with capital, especially economic capital. The notion of social innovation first appeared in the 1970s (see Chapter 1). At the time, it was understood as an openness to consider other processes, actors and results, originally in a posture that was very critical of technical progress and its effects, then through more diverse approaches that incorporated the participatory construction of compromises between the various dimensions of sustainable development (Laville, 2014). The proliferation of crises at the beginning of the 21 st century, many of which continue to persist even after several years, is reviving interest in this notion and the processes that constitute it (Klein and Harrisson, 2007).

In a recent review covering a wide gamut of work, Richez-Battesti et al. (2012) proposed three ways of thinking about social innovation today. The first views it as a tool for modernizing public policies in order to better respond to social problems. It thus encompasses new modes of intervention that leverage the partnership between the public and the private sectors. In the food sector, the implementation of territorial food projects (French acronym: PAT[16]), based on a concerted development at the territorial scale, can be understood in this perspective. The second way of conceiving social innovation refers to the activities of social enterprises and social entrepreneurs, who undertake market activities that have economic as well as social purposes. In the food sector, the Food Assembly[17] (in French: Ruchequi-dit-oui), an Internet buying platform linking consumers to local producers, is part of this tradition, even if this enterprise, initially recognized for its social utility, has since become controversial, especially because of its dependence on private shareholders. The third way of thinking about social innovation is through bottom-up, multi-stakeholder collective processes that emerge in a territory to address social needs that are not being met by public policies and markets or to translate an aspiration for change. The AMAPs (Associations for the maintenance of a peasant agriculture)[18], solidarity exchange systems between producers and consumers, are an example often cited in the literature to illustrate this third acceptation. Indeed, together with community or shared gardens, they constitute the only examples from the food sector that are cited in the literature on social innovation in general. 


\section{From an institutional analysis of social innovation to the highlighting of issues that require further in-depth study}

When applied to bottom-up and multi-stakeholder collective processes, analyses, mainly in the field of institutional economics, lay emphasis on the importance of the institutional and local contexts, as well as the learning and coordination processes that underlie changes in practices and the coproduction of new rules and standards (Klein and Harrisson, 2007). In these situations, too, inventions are most often the result of everyday activities of organizations or the ordinary life of citizens, which just highlights the disconnect with investment policies that encourage technological innovation. Over the longer term, this type of local innovation can arrive at results that go beyond the framework of the local actors' project to even call prevalent development models into question: social innovation then becomes a vector of social change.

Richez-Battesti et al.'s (2012) review, nevertheless, reveals several types of challenges, both theoretical and methodological, in analysing and supporting social innovation, irrespective of the definition used. One of the first challenges is to understand the conditions that are conducive to the emergence and dissemination of these innovations, in the third type of situation in particular (bottom-up and multi-stakeholder process). Who are the individual or collective actors in ordinary life who initiate new rules and practices aimed at solving socio-economic problems, fulfilling unmet social needs or translating aspirations for change? What are the channels for disseminating these innovations at the local level and, in a perspective of social transformation, at higher organizational levels? Another major challenge is to find methods to evaluate social innovation processes in a way that can help avoid the misrepresentation of the concept by operators who instrumentalize social goals to serve their own economic or political strategies. Before revealing the analytical framework we propose to use to address these questions, we briefly present the studies referring to actornetwork theory that already provide some elements of an answer, albeit incomplete. 


\section{A first - but inadequate - analysis grid}

To understand the emergence of a local innovation and its capacity to transform higher organizational levels, Actor-Network Theory (ANT) can be used as a first analysis grid: the innovation is built through a network of actors and objects mobilized around a new idea. The socio-technical network formed in this way can contribute to an evolution of society and markets. Indeed, Callon (2007) uses the notion of social innovation to show the role played by inhabitants of northern Japan, who were affected in the 1970s by a disease initially of unknown origin. Their participation not only helped to identify the source of the disease, polluting discharges from a mine into a downstream river, but also to implement solutions. More broadly, Callon shows how markets and associated technologies generate topics of concern that trigger the emergence of 'concerned groups' that ultimately play a role in the dynamics of innovation (Callon, 2007).

Drawing on the contributions of actor-network theory and of science and technology studies and combining them with those of the evolutionist economy (see Chapter 1), studies undertaken over the past decade and grouped under the term 'theories of transition' also seek to understand how major transformations take place in the way societal needs, such as housing, education, health, nutrition, etc. are met. The approach is that of a multilevel analysis of transformations resulting from interactions between different types of socio-technical systems (Geels and Schott, 2007). The analytical levels are the niche sources of radical innovations (micro level) - which can be social, even if the notion is not used in these studies; the regime (meso level) composed of norms, rules, and public and private knowledge and actors who ensure the stability of dominant practices and technologies; and the landscape (macro level) representing the context formed by the institutions, flows, and social values over which actors have little control. Studies using this approach are proliferating but they face several criticisms, including that of taking little account of the diversity of actors, their relationships and their strategies (Lamine, 2012). In fact, most often, the analysed cases present niches formed by actors who can be called 'alternative', in that they are opposed to the dominant system and are proponents of radical innovations. They thus tend to obscure the dynamics of change driven initially by the actors in ordinary life, which are pointed out 
more clearly in Callon's work. In addition, the transformations of the dominant system are analysed as being related to the opening of a window of opportunity in the regime, under pressure of the landscape and/or niches, without any precise visualization of the underlying social mechanisms (Smith, 2007). We therefore propose to rely on another interpretive framework to take forward the analysis of the emergence of local innovations and their transformative capacity, especially in the case of social innovations.

\section{The construction of a new interpretive framework}

We therefore propose to combine two types of contributions to analyse social innovation: those of economic sociology and those of the ethic of care. Starting from economic and network sociology, also called new economic sociology, we analyse social innovation through the social relationships that build it. Our approach thus dovetails into the conception of an economic and technological activity 'embedded' in social structures, especially in interpersonal relationships, at the foundation of the new economic sociology (Granovetter, 1985). In line with the work of Grossetti (2008) on the creation of innovative companies, we also take into account the other forms of mediation (organizations, media, etc.) on which the actors rely to acquire the resources necessary to implement changes (information, legal aid, etc.). Furthermore, it is a matter not only of analysing the social relationships and mediation resources involved in the dynamics of change, but also of taking into account the diversity of the actors' strategies, and, in particular, of incorporating the quest for social status through participation in the innovation (Lazega, 2002). The evaluation of the effects of social innovation thus has to include the motivation behind it.

The new economic sociology also provides the means to reflect on the dissemination of the social innovation beyond the local situation and on its transformative capacity. Scaling can indeed be understood as a process of decoupling, the opposite process of embedding, in which the invention extracts itself from the social relationships that created it (White, 1992), through new devices for example. However, this stream of economic sociology is ultimately little concerned with individualities and how they evolve within networks beyond their ability to provide resources for 
innovation. Taking these individualities into account is however essential if one wants to analyse innovations aimed at fulfilling an unmet social need or to translate an aspiration for change.

The ethic of care, as proposed by Tronto (1993) in particular, recognizes vulnerability as constitutive of human life, starting from the principle of interdependence between everyone's lives and everyone's responsibility for, and in relation to, the lives of everyone else. This approach consists of looking at the work undertaken in ordinary life by sensitive and singular actors, to 'maintain, continue and repair our world' (Ibid.), in order, for example, to facilitate access to good quality food by populations in vulnerable situations. The ethic of care also shows how this endeavour leads various actors to lash out at the institutions that are responsible for making people vulnerable or invisible, as has been the case regarding those who supervise food aid (Paturel, 2010). This approach then leads to an analysis of the solutions implemented by the actors to obtain recognition and to open up new possibilities for excluded or vulnerable people. These solutions consist of new practices and new mechanisms, which, by modifying certain power relationships, become sources of social transformation (Molinier et al., 2009).

The combination between new economic sociology and the ethic of care makes it possible to propose an original framework for apprehending social innovation: it can be understood as a process based on personal relationships, mobilizing singular actors who are, or become, sensitive to the need for recognition, for themselves and for others. This process is rooted in a local situation and is constructed at the outset or along the way in reference to a global context. It relies on resources and is able to make encompassing levels evolve through the creation of devices decoupled from local interactions, vehicles of social recognition and harbingers of new possibilities.

\section{W Two stories of social innovation concerning access to food for all}

On the basis of this new interpretive framework, we examine two examples from southern France, representative of current bottom-up dynamics concerning food. They are focused on the problems of access to food and on 
trying out solutions based on short supply chains as well as on the participation of vulnerable actors:

- a purchasing group formed by persons entitled to social minima benefits;

- a solidarity shop, open not only to those in vulnerable situations but also to people with higher incomes.

Both initiatives have been analysed since their inception. The analysis combined participant observation during meetings and individual interviews that led to narratives, especially of relationships built or broken due to the initiative. Our method is similar to that of quantified narratives, developed by Grossetti following his work on the creation of innovative companies. We use narratives of practices, in particular, to determine the relationship chains that build innovation, much as in the method of quantified narratives, but by additionally taking into account the individuals who participate in them and the effects that the innovation generates at their level. In interviews, taking individualities into account is also essential to establish contact with vulnerable people and to build relationships of trust with them, even if it is not enough to eliminate the asymmetries between the interviewer and the interviewee.

\section{The lacklustre story of a purchasing group aiming at social diversity}

In a large city in southern France, a purchasing group was formed in 2009 following a cooking workshop entitled 'Smart and gourmet cooking for next to nothing' organized for the city's social minima beneficiaries. This workshop was conducted by a restaurant owner convinced that it is possible to cook with fresh agricultural produce at low cost. The link between the restaurant owner and the workshop participants was encouraged and overseen by two social workers. Until then, the participants were strangers to each other and some of them had never had a direct relationship with the agricultural world. They were eager to pursue this endeavour in their daily lives by finding the means necessary to obtain good quality agricultural products at prices commensurate with their level of resources. The social workers organized a meeting for discussion. A first link was established between the group and a producer through an AMAP arrangement, then a 
visit was organized to a social grocery store[19]. It led them to specify their project: their wish was to find a way to avoid the stigma usually associated with those who had to take recourse to social grocery stores and which was, for producers, less restrictive than AMAP. Links with other producers, especially with a young person in the process of establishing himself, and with rural development actors were formed thereafter and reinforced the idea of forming a purchasing group that would seek a socially diverse membership and with a more flexible way of functioning than AMAP.

The concrete action of the group flowed from the daily reality of its members: they started by listing the fruits, vegetables and basic commodities (rice, flour, etc.) that they all consumed. They then organized themselves to compare the prices of products in different outlets. This information on prices became an important mediation resource in the group's trajectory and its innovative approach (Grossetti, 2008), not in itself, but because it acquired sense through the link established with producers. Indeed, the discussion made it possible to understand the price variations between the sales outlets due to differences in product quality (in particular in terms of the duration between harvest and consumption) and on the basis of the price finally paid to the producer. It also helped overcome the idea that products sold through direct sales are always more expensive than when sold through longer supply chains.

However, while the group agreed on its plan to buy from producers, it was slow to implement the approach, primarily because the income mix was difficult to achieve. The group, very limited in financial resources, did not therefore represent sufficient demand for a farmer. As one of the latter explained to them, the time spent preparing and delivering the products would not be remunerative. Nevertheless, it was as much a social link that was being sought through the initiative as the solution to a real problem of everyday life, so much so that meetings were mainly used to discuss and share the hardships of everyday life.

In terms of networks, the initiative did create new types of links with institutions interested in social innovation. These institutions not only offered the group new resources (grant, formalization of the project, etc.), but, above all, they gave the group recognition on the public stage, recognition which 
people in vulnerable situations often feel deprived of (Honneth, 1995). However, these links soon dissipated given the time needed for the group to assert its values and create the conditions for putting the innovation into practice. The breakdown of these links led some members to leave the collective. Some, however, still pursued the endeavour and finally entered into a partnership with a fruit and vegetable producer. In addition, two members were recruited and remunerated by one of the institutions that had followed the project. Even though their own initiative had failed to live up to its initial expectations, they were asked to share their experience during support sessions organized for the promoters of other social innovation projects. This institution also drew lessons from this example to modify its programme to support social innovation, previously solely targeted at social enterprises, by opening it up to bottom-up multi-stakeholder initiatives.

\section{The success story of a solidarity shop}

The second example is that of a solidarity shop, which emerged in 2009 from a meeting between producers in difficulty and social minima beneficiaries. This meeting was organized by an agricultural association and a poverty alleviation association that were put in touch by a social worker who was formerly a farmer. Here, too, the decisive link was created between consumers and one of the producers. He explained that when he sold his apple production to supermarkets at $0.35 € / \mathrm{kg}$, he did not make money. For him to do so, he needed to sell at a price of at least $0.50 € / \mathrm{kg}$. The people in vulnerable situations were sensitive to and understanding of this statement and said that, despite their limited budget, they were ready to make an effort to provide a fair remuneration to the producer. As in the case of the purchasing group, here too, the challenge was to find a formula that avoided the stigmatization of people in difficulty.

The project took the form of a solidarity shop, open to all but with different price levels which depended on the buyers' incomes. The associations supporting the project involved local food-aid institutions, which brought in other social minima beneficiaries. The beneficiaries could buy food products at cost, while the operating costs of the shop were covered by the more wellto-do consumers, who had to pay more for the same products. This solidarity 
shop, based on those originally set up in English-speaking countries, was one of the first of its kind in France. Its coordinators introduced another organizational innovation, consisting of dividing management into three parts: concerning producers, concerning consumers, and concerning associations, communities and institutions. This method of management allowed the food-aid institutions to better understand the issue of the participation of people in vulnerable situations in the shop's operational decisions. In fact, participation allowed these people not only to obtain their food, but also to regain a status as actors, a status that had been eroded by financial difficulties and the associated stigma. The creation of several thematic committees (product quality and pricing, organization of production, etc.) helped maintain a participatory manner of functioning and ensured that the participants' constraints, especially economic ones, were not forgotten. The shop emerged as a space for meetings, debates and learning (Klein and Harrisson, 2007), providing consumers and institutions an opportunity to understand the difficulties of the agricultural world.

Six months after the launch of the initiative, the shop had 2500 members, of whom 256 benefited from cost pricing and accounted for $15 \%$ of the products on offer. The price of a product was different for each consumer and was fixed, as in other social intervention experiments, on the basis of his or her 'reste-à-vivre', i.e., a consumer's real resources after basic expenses had been deducted from his or her income, and not on the family quotient. The originality of the shop also derived from the fact that each member received a payment card whose use ensured that the price being charged was not displayed during the checkout process. No proof was required at the shop since that process had been completed upstream. This innovation combined practicality with respect for people. It was the result of an unprecedented dialogue between the beneficiaries and the food-aid institutions, which the context of the shop first allowed to be established and then to be transformed into an innovative mechanism. Subsequently, this innovation went beyond being simply a local initiative and was replicated in other territories, through information conveyed via interpersonal links.

\section{Embedding and decoupling of social innovation, towards a change of scale}




\section{Social innovation, a dynamic of relationships between singular actors}

In the two cases presented above, innovation emerged from the encounter or, more accurately, from the relationships between actors of different statuses. It often evolved into spheres that were little or not at all connected before, with the final result not being attributable to any particular actors. However, even though links were established and created a context propitious to finding a solution to the generic problem of access to food for people in vulnerable situations, it was only because of singular individuals, not only sensitive to situations being experienced by less fortunate others but also motivated by pragmatic and, in part, personal concerns. These two cases thus illustrate, more broadly, the new relationships between individual interests and solidarity (Laville, 2005).

The actors involved also had specific experience. This was the case of the 'clever chef' in the first initiative, already offering fresh-produce dishes at affordable prices in his restaurant. This was the case, too, in the second initiative, of the social worker who, because he had been a farmer, knew the difficulties faced by certain farmers and thought that sharing them with consumers in vulnerable situations could form the driving force for collective action. At the same time, this second case shows that the links that are created and that build the innovation are also, in part, enabled by the relationship history of some of the actors involved. The social worker had indeed maintained links with the agricultural world, which not only facilitated the building of a relationship between producers and beneficiaries but also motivated it. Furthermore, as Grossetti (2008) shows in his longitudinal analysis of the creation of innovative firms, innovation also feeds on personal relationships formed in other contexts. In the case of the purchasing group, for example, the first producer in AMAP contacted by the group was a former high school friend of the daughter of one of the participants.

\section{A process partially driven by changes in social status}


As noted above, Grossetti's work presents the stories of relationships only in terms of the resources they can provide for the innovation. But the stories recounted above show how innovation is also driven forward by another type of content, concerning individual recognition and which helps accord new social statuses to the people involved in the process. Furthermore, relationships are broken off by some actors when the relationships do not, or no longer, allow them to feel recognized, as the case of the purchasing group shows. This quest for status is no doubt made more acute by the situation of the people considered here, who are vulnerable or even excluded, and for whom integration involves the (re)building of links, especially with the institutions concerned. In any case, social recognition is confirmed here as one of the engines of innovation, as shown by studies carried out in very different contexts, even when the social exclusion of some is not in question. In his analysis of a business law firm, Lazega (2002) shows, for example, that lawyers participate in the search for new solutions to new problems in exchange for an enhancement of their status. This enhancement takes the form, in particular, of being allowed to give advice to others, with this relationship providing a way to overcome formal hierarchies. This dynamic is also found in the initiatives studied here, since, in the case of the purchasing group for example, the beneficiaries were able to advise social workers on the benefits and the ways of involving children from disadvantaged neighbourhoods in cooking workshops.

However, unlike what happened in the law firm, the symbolic capital associated with social innovation - not only through its goal but also through its participatory construction - offered the participants of both innovating projects studied a rewarding collective identity. According to many of them, they felt they were producers as well as beneficiaries. In the case of the purchasing group, this collective identity initially helped compensate for individual frustrations in the quest for status and 'attach' participants to the innovation (Callon, 1986). It was, however, not strong enough to retain their commitment over the long term. In the case of the solidarity shop, on the other hand, the collective identity was quickly affirmed, through an innovative method of functioning, which was soon used as a model elsewhere and praised and reported by the media. Thus decoupled from the relationships that created it, the collective identity also benefited newcomers to the shop, which contributed to its continued existence. 


\section{A first approach to scaling mechanisms}

The analysis presented here makes it possible to explore some of the mechanisms for scaling social innovation, which are little covered by existing theories of transition, and even less so at the theoretical level in the literature on social innovation (Bucolo et al., 2015). Indeed, the approach through networks of these two initiatives calls for further study of the relationship chains since these chains convey values and ways of acting that can influence other territories as well as encompassing institutions. The analysis presented here also invites us to further explore the conditions under which the content exchanged in these new relationships can lead to new rules, sometimes even to new devices. In the case of the shop, for example, collective functioning played a fundamental role in this respect. These new rules or devices, which translate and concretize the innovating dimension of the local initiative, form mediation resources used by others to modify existing operations, in other territories or in surrounding institutions. An apt example is the appropriation, in contexts different than that of the solidarity shop, of the invention of the adapted payment card. Nevertheless, our analysis shows that this decoupling, which allows for a scaling of the innovation, does not necessarily mean a disembedding from the local. Indeed, it helps, on the contrary, evolve the links between the actors of the social innovation around a collective identity affirmed by the sharing of values and rules which are valued beyond the local scale.

Moreover, from the ethic of care perspective, the scaling of a social innovation is not measured solely by the dissemination to other spaces of new (good) practices, rules or associated devices. In the perspective of social change, scaling is also understood through a social innovation's ability to enhance the status of individuals in social contexts marked by relationships of domination. In the two cases presented here, from a passive and potentially controlled individual (by the food-aid system, in particular), the person in a vulnerable situation becomes competent and recognized for his advice on implementing the social innovation. He also expresses his solidarity, despite his limited resources, with local farmers through his support for them and no longer remains simply a beneficiary of the solidarity of others or of the State. The ethic of care thus shifts the analysis towards the capacity of initiatives not only to respect singular individualities, but also to come up with devices 
that offer new rights to usually excluded persons, thus modifying certain relationships of domination.

\section{Conclusion: a new reading of social innovation through the food sector}

Research on innovation is taking on a new dimension with the emergence of social forms of innovations that do not find a place in a logic of technical or technological progress and which are finding legitimacy in the current context of crises. Based on the contributions of the new economic sociology and enriched by the ethic of care, the research presented here seeks to account for the processes involved in this form of innovation through two initiatives for facilitating access to a good-quality diet for families in vulnerable situations. The proposed approach relies on an analysis of the dynamics of interpersonal relationships. It takes into account all that these relationships convey and all that they contribute to innovation, in conjunction with the individualities that activate these relationships and the way they engage in them. The results highlight the importance of the experience gained in ordinary life, which makes it possible for the actors to forge links that go beyond hierarchies even as they endeavour to attain recognition and status. These results thus partly illustrate the conditions and the mechanisms of a dynamic of embedding and decoupling, iterative and personified which gives body and meaning to new practices, locally as well as at more encompassing levels. These results are in line with those of research grouped under the term 'theories of transition', which call the diffusionist model of innovation into question and explore new niche-driven processes, but which often limit the capacity for change to particular actors. Our approach offers a more open and precise reading of the conditions conducive to the emergence of these bottom-up innovations and invites us to continue to explore their specific scaling mechanisms. Ignored for the most part by the literature on social innovation, the food sector thus confirms itself as being a particularly interesting field for producing new knowledge on this form of innovation.

\section{Bibliography}


BEPA, 2011. Empowering people, driving change: social innovation in the European Union. European Commission, Brussels.

Bucolo E., Fraisse L., Moisset P., 2015. Innovation sociale, les enjeux de la diffusion. Sociologies Pratiques, 31,1-6.

Caillavet F., Andrieu E., Momic M., Lhuissier A., Régnier F., 2006. L'alimentation comme dimension spécifique de la pauvreté. Approches croisées de la consommation alimentaire des populations défavorisées. In: Les Travaux de l'ONPES 2005-2006. (ONPES, ed.), La Documentation française, Paris, 247-278.

Callon M., 1986. Éléments pour une sociologie de la traduction. La domestication des coquilles Saint-Jacques dans la baie de Saint-Brieuc. L'Année sociologique, 36, 169-208.

Callon M., 2007. L'innovation sociale. Quand l'économie redevient politique. In: L'innovation sociale : émergence et effets sur la transformation des sociétés (Klein J., Harrisson D., eds), Les Presses de l'Université du Québec, Quebec.

Celavar, Inra (eds), 2010. Circuits courts et cohésion sociale. Celavar, Paris.

Chiffoleau Y., Paturel D., 2016. Les circuits alimentaires « pour tous », outils d'analyse de l'innovation sociale. Innovations, 50, 191-210.

Geels F.W., Schott J., 2007. Typology of sociotechnical transition pathways. Research Policy, 36(3), 399-417.

Granovetter M.S., 1985. Economic action and social structure: the problem of embeddedness. American Journal of Sociology, 91(3), 481-510.

Grossetti M., 2008. Réseaux sociaux et ressources de médiation dans l'activité économique. Sciences de la société, 73, 83-103.

Honneth A., 1995. The struggle for recognition: the moral grammar of social conflicts. Polity Press, Cambridge, Mass.

Klein J.-L, Harrisson D. (dir.), 2007. L'innovation sociale : émergence et 
effets sur la transformation des sociétés, Les Presses de l'Université du Québec, Quebec.

Klein J.-L., Camus A., Jetté C., Champagne C., Roy M., 2017. La transformation sociale par l'innovation sociale. Les Presses de l'Université du Québec, Quebec.

Lamine C., 2012. Changer de système : une analyse des transitions vers l'agriculture biologique à l'échelle des systèmes agri-alimentaires territoriaux. Terrains \& travaux 20, 139-156.

Laville J.L, 2005. Sociologie des services : entre marché et solidarité. Eres, Paris.

Laville J.-L., 2014. Innovation sociale, économie sociale et solidaire, entreprenariat social. Une perspective historique. In: L'innovation sociale (Klein J.-L., Laville J.-L., Moulaert F., eds), Eres, Paris.

Lazega E., 2002. Réseaux et capacité collective d'innovation : l'exemple du brainstorming et de sa discipline sociale. In: Recherches sur l'innovation (Alter N. ed.,), La Découverte, Paris, 183-210.

Molinier P., Laugier S., Paperman P., 2009. Qu'est-ce que le care? Souci des autres, sensibilité, responsabilité. Payot, Paris.

Paturel D., 2010. Alimentation et lien social : les circuits courts comme alternative ? Revue économique et sociale, 68(4), 61-70.

Richez-Battesti N., Petrella F., Vallade D., 2012. L'innovation sociale : une notion aux usages pluriels ? Quels enjeux et défis pour l'analyse ? Innovations, 38, 15-36.

Serres M., 2014. Thumbelina: The Culture and Technology of Millennials. Rowman \& Littlefield International, Lanham, MD.

Smith A., 2007. Translating sustainabilities between green niches and sociotechnical regimes. Technology Analysis \& Strategic Management, 19(4), 427450 . 
Tronto J., 1993. Moral boundaries. A political argument for an ethic of care. New York - London, Routledge.

White H.C., 1992. Identity and control. Harvard University Press, Harvard.

\title{
Chapter 6
}

\section{Innovation, a precondition for the sustainability of localized agrifood systems}

\author{
Stéphane Fournier, François Boucher, Claire Cerdan, \\ Thierry Ferré, Denis Sautier, Didier Chabrol, Bernard \\ Bridier, Jean-Paul Danflous, Delphine Marie-Vivien and \\ OpHÉLIE RoBINEAU
}

Summary. Small-scale food production and products of terroirs often evoke a traditional image, one of practices frozen in time, transmitted from generation to generation. The reality is however different: analyses show that localized agrifood systems (LAFS) have to innovate constantly in order to cope with internal changes (reduction in the capacity of coordination and collective action) and/or external ones (new constraints, or technical or commercial opportunities). Faced with this need to innovate, some systems are able to increase interactions between local and extra-local actors, leading to technical or organizational innovations. The LAFS concept makes it possible to shed more light on these collective and localized innovation processes than diffusionist schemes do, and to also show the way to support them.

Small-scale or artisanal food production often evokes a traditional image. Local or terroir products are viewed as having immutable characteristics and as being produced using age-old practices that are transmitted from generation to generation. And yet, studies of these products reveal processes of innovation, occurring over shorter or longer periods: sectors appear and disappear, and production systems adapt to changing technical, regulatory 
and market environments. What are the determinants of these innovation processes? What are their enabling levers and their retarding obstacles? What analytical frameworks can be used to apprehend them?

This chapter addresses the issue of innovation processes in territory-linked agrifood production. We determine the strengths and weaknesses that result from the collective dimension and territorial anchorage of these processes. The first part of the chapter discusses the 'localized agrifood system' (LAFS) model, situating it with reference to studies on industrial districts and clusters, and clarifies the nature of the innovation processes at work. The second part examines the capacity of this LAFS model to engender and orient development programmes and analyses some of the possible levers for strengthening local dynamics of innovation and the qualification of food products.

\section{Using the concept of the localized agrifood system to explain the dynamics of innovation in small-scale production}

The study of the dynamics of innovation at work in small-scale or semiindustrial agrifood production reveals two salient facts: these dynamics are collective in nature and they are localized. Collective because they are observable among different small-scale producers, without it being possible to identify the first innovator, assumed by Schumpeter (1934) to have a key role in the innovation. Localized because these dynamics occur only in certain spaces, with traditional practices being more prevalent in others.

The collective nature of these dynamics of innovation can be explained in the light of evolutionary theories (see Chapter 1) and of industrial economics. These theories help explain the complexity of technological change, technological lock-in[20] phenomena, and the resulting technical and organizational routines (Nelson and Winter, 1982). A small-scale producer is not able to break from these routines on his own, i.e. assume all the costs and risks associated with the process of developing a new technology and of producing enough of the new product to establish trading channels. On the contrary, technological change requires a high level of coordination within a 
group. The iterative process of testing, followed by the necessary corrections, and the trial and error which gradually allows the construction of an innovative technique have to be shared.

The second characteristic, the localized nature of these dynamics of innovation, seems to be more difficult to explain. Given the same environment in terms of technical and market opportunities, why do all production regions not have the same capacity to innovate? Why are some regions more successful in seizing these opportunities or overcoming new constraints? What is the nature of the resources that induce a process of development in certain spaces and not in others? The localized nature of the technical changes observed in agrifood sectors requires us to clarify the nature of actor collectives and their relationships.

\section{Endogenous cooperative relationships are formed more easily in certain spaces}

To understand these technical changes, an analytical framework was built around the model of the localized agrifood system, or LAFS (Muchnik and Sautier, 1998; Muchnik et al., 2007). This LAFS model was inspired by that of the localized productive system (LPS), developed by various French authors (see Courlet (2002) for a literature review) following the emphasis placed on the importance of the 'local' by Italian authors in the context of Marshallian industrial districts (Becattini, 1992). However, because of the nature of the productions in question (small-scale or semi-industrial food production), the LAFS differ in their functioning from more industrialized localized production systems. Indeed, in the LAFS, the territorial anchorage imbues more typicality to the product than in the LPS because of possible effects related to the terroir (when it comes to agricultural production and/or agrifood processing) and because of the potential inclusion of this product in a process of patrimonialization (Fournier and Muchnik, 2012). The analytical framework of LAFS has to necessarily be multidisciplinary, based in particular on economic, geographical, socio-anthropological and technological approaches. It has to include an analysis of the actors, their practices and uses of the territory, across different spatio-temporal scales (Chevassus-au-Louis et al., 2008). 
Even though the LAFS model is thus distinct from that of the localized productive system, the studies concerning them do, in common, approach innovation processes directly at the level of systems of actors. Innovation in small-scale agrifood production is thus attributed to interactions emerging within systems 'made up of production and service entities (agricultural production units, agrifood companies, commercial enterprises, service companies, restaurants, etc.) linked by their characteristics and their functioning to a specific territory' (Muchnik and Sautier, 1998).

In a localized agrifood system or a localized industrial production system, the actors enter into subcontracting relationships, exchange information through consultation networks, create projects of common interest, etc. These types of interactions supplement the simple competitive relationships that naturally exist between a region's agrifood producers. These relations of 'coopetition' (cooperation and competition) in areas of geographical concentration of activities of a similar nature then strengthen the dynamics of innovation, a phenomenon that Porter (1998) illustrates with the notion of cluster. In the LAFS model, the perception of the collective interest can help cooperation largely overshadow competitive relationships.

A localized agrifood system, like a localized productive system or an industrial district, can thus be seen as the coupling of a production system with an innovation system, with the latter being both sectoral (Geels, 2004) and regional (Asheim et al., 2011). Recent analyses of these innovation systems make it possible to re-examine the processes of innovation at work in a LAFS.

It remains to understand where this capacity for cooperation comes from in lateral relationships which, logically, should be purely competitive, and why it finds stronger expression in certain spaces than in others. The nature of the proximity that unites the actors appears to be a key point. While there is geographic proximity between actors in every production area, interactions can also be facilitated by organized proximity (Pecqueur and Zimmermann, 2004). The latter is achieved through common norms and values, and/or memberships of the same networks, organizations or communities. In industrial districts, this organized proximity is seen to pre-exist but in localized production systems and LAFS, it has to be constructed explicitly 
and progressively through interactions.

The potential role of geographical and organized proximity in innovation systems has long been recognized. It leads, first of all, to a minimization of transaction costs, with mutual knowledge and sharing of common values reducing the risk in exchanges. Such proximity also promotes innovation by making it easy to share and combine tacit knowledge and codified knowledge. Finally, this proximity makes it possible to build up social capital, which then accelerates the dissemination of innovations (Van Rijn et al., 2012).

Because of this geographical and organized proximity, local actors can construct institutions, in the sense given to the term by North (1994), over the long term, which then govern their interactions via formal and informal organizations. These progressively established rules of the game guarantee the reciprocity of commitments in processes of collective action (notably by establishing sanctioning mechanisms) and slowly engender relationships of trust (Ostrom, 2010). This trust between actors leads to social learning, which is a key element of an innovation system's effectiveness (Sol et al., 2013; Stuck et al., 2016).

Finally, geographical and organized proximity strengthens territorial solidarity. Over the long term, the actors living in these spaces start behaving like they belong to a community, in some cases toning down or suppressing individualistic or opportunistic behaviours. The interest of the individual can be perceived as no longer taking precedence or, in any case, as being strongly dependent on that of the community. This phenomenon, highlighted by the work of Becattini (1992), removes many of the barriers that hinder cooperation, collective action and ultimately (collective) innovation processes in certain spaces. The individual does not necessarily feel obliged to protect his know-how, his inventions, or his information if their dissemination strengthens his community.[21] In the face of a collective long-term vision that is being formed, he is more likely to build specific assets collectively (Gallaud et al., 2012).

On the basis of the theoretical advances on innovation systems, the LAFS model thus makes it possible to better understand the emergence, in certain spaces, of deeper cooperation relationships that ultimately lead to innovation 
processes. An institutional and organizational mechanism develops and transforms these spaces into territories. This mechanism is the main specific strength and asset of LAFS (Cerdan and Fournier, 2007).

\section{External contributions}

However, these endogenous dynamics cannot fully explain innovation processes, either within LAFS or, more generally, within innovation systems. A LAFS's strength originates also from its ability to capture ideas, innovations and new practices from outside, and to combine them with its own practices to reinforce or renew innovation processes. Relationships that local economic actors maintain with other companies, research centres, and support organizations are often essential to stimulate innovation processes. Several authors have noted the importance of building innovation platforms that reach beyond merely local systems (Schut et al., 2016; Hounkonnou et al., 2012).

In addition, a LAFS's capacity for innovation is highly dependent on the nature of the interactions between producers (farmers, artisans, and small and medium enterprises) and consumers. Local markets, which benefit the LAFS, at least initially, allow physical meetings between these various actors and rapid feedback from consumers to producers, enabling a co-construction of LAFS innovations. These interactions provide a framework for the processes of innovation for products with high symbolic value forming part of the local heritage, characteristics that innovations must not dilute (Chabrol and Muchnik, 2011). Subsequently, markets for LAFS products can expand, but the local component consisting of consumers, diasporas and connoisseur communities are likely to continue to play a role in orienting innovations. Consumers are thus involved in innovation processes that lead to new terroir products (Prévost et al., 2014). On a more general level, the importance of interactions in innovation systems between the product's producers and its users has been emphasized by Geels (2004). Torre and Tanguy (2014) argue that it is the existence of 'gatekeepers', who provide the connection between the industrial districts and the world market (because they know both very well), that is the source of these systems' strength. 
The interactions between the innovation system associated with a LAFS and its environment are thus decisive. In a more recent article, Geels (2014) considers it necessary to analyse a triple nesting of enterprises: in an external environment, economic as well as socio-cultural, and in their industrial regimes, corresponding to specific sectoral dynamics.

In summary, thus characterized, the LAFS model makes it possible to build an analytical framework of the evolutionary trajectories of agrifood production systems (Muchnik et al., 2007). The ideal innovative LAFS is characterized by these relationships of cooperation and competition allowed not only by a strong local institutional mechanism, these multiple proximities and this territorial anchoring, but also by the relationships that the system's actors are able to establish with the outside world (Boucher, 2004; Fournier, 2002).

\section{A process of innovation in fits and starts}

The innovation process in LAFS is however not linear; it takes place in fits and starts, as can be seen from the example of cottonseed oil mills in BoboDioulasso (Box 6.1).

\section{Box 6.1. Cottonseed oil mills in Burkina Faso: organizational innovations at the service of technical innovations}

Bobo-Dioulasso, the second-largest city in Burkina Faso, has experienced remarkable growth over the last decade in small and medium enterprises (SME) specializing in the production of edible cottonseed oil and oilcakes for animal feed. This cluster of companies joined an older industrial base, consisting of an industrial cotton ginning company (SOFITEX) dating back to the 1980s and two industrial cottonseed crushing companies (SN-CITEC and SOFIB) which, for a long time, had operated without competition.

At the end of the 1990s, the first small oil mills were set up by technicians from the industry and from companies that manufacture spare parts for industrial oil mills. The local manufacture of copies of 
imported presses (Chinese and Indian) led to the emergence of very small enterprises (VSE) to take advantage of the market for oilcake for animal feed. The oil was then sold to street food makers and artisanal soap factories.

In the early 2000s, these VSEs began proliferating. They acquired imported presses and increased considerably their production capacity and the number of employees, and started turning into SMEs. They then shifted production to higher-quality refined oil, packaged under their own brands, and began competing with industrial companies.

As these SMEs became active, competition between them and SOFITEX over cottonseed procurement became more intense. The SMEs then formed a professional group (GTPOB) to lay claim to an appropriate amount of cottonseed supply. The government officially recognized this group and fixed seed quotas for each party. This organizational innovation thus made it possible to secure supply over the long term.

The creation of this professional group, by bringing together the sector's actors, had other positive impacts: emergence of new skills and capacities in oilseed crushing, creation of related activities of equipment maintenance and spare-parts manufacturing, emergence of local capabilities in equipment manufacturing and maintenance, etc.

In 2011, GTPOB had 44 members and reported a turnover of more than 4 billion FCFA (about 6 million Euros). It was experiences like this that led Burkina Faso to reorient its industrial policy more towards competitiveness clusters and localized production systems. In recent years, however, Bobo-Dioulasso's oil production sector has had to contend with the entry of many new actors mainly because the professional organization has been unable to regulate the workforce. In 2017, in this city alone, there were nearly a hundred SMEs. Not only is cottonseed supply seeing renewed tensions, but the cottonseed oil market is experiencing stiffer competition. New strategies are already emerging and some mills are diversifying to sesame or soya bean. 
The analysis of innovation processes shows the different phases that exist in a LAFS's life cycle. The various types of local innovation and production systems - LAFS, localized production systems, and clusters - all face the same threat in case their innovations are successful: an increase in competition due to the entry of new actors. While localized production systems and clusters are protected to some extent from the risks of rapid expansion by high entry barriers (difficulties in acquiring technologies, size of initial investments, etc.), this is rarely the case for LAFS. The relatively easy possibilities of expansion of these systems then create a life cycle composed of distinct phases:

- initially, the innovation concerned is produced by a small number of producers, closely linked by geographical and organized proximity, participating in relationships of trust or even cooperation; this innovation is able to differentiate local production;

- if this local activity generates significant profits for the producers, the LAFS spreads rapidly since the entry barriers consist mainly of know-how, which is easy enough to acquire locally, and of a small initial investment; this extension leads the LAFS to include actors who are less and less close, who have only the practice of the same activity in common with the innovation's community of origin;

- as long as the activity continues to provide strong margins, the number of producers continue to increase and the spatial expansion continues; past a certain stage, this growth may lead to a commoditization of the product, a fall in prices, or even a situation of overproduction; new innovations are then needed, but these are more difficult to achieve at the LAFS's scale, due to the large number of actors, their lack of proximity and the increasingly competitive relationships between them; without collective innovation processes, this phase is characterized by a decline in the LAFS; the decrease in, or even the disappearance of, profits causes a reorientation of the actors towards other activities and/or the consolidation of enterprises;

- at this point, the actors at the origin of the LAFS have to innovate again in order to reintroduce a specificity into their product or in their mode of production or wait until the fall in production makes prices rise again (Fournier, 2002).

Although this life cycle (emergence, growth, decline, potential recovery) is not specific to LAFS, it nevertheless shows the difficulty of maintaining a 
process of innovation over time, as well as the sometimes ephemeral nature of territorial dynamics (Fournier et al., 2005).

Following the reduction or the disappearance of the increased income from the initial innovation, new innovation processes are nevertheless able to emerge, thanks to the existing proximity between the actors, the trust that exists between them, the cooperative relationships and activities, the institutions in place, etc. (Courlet, 2002). Thanks to the initial innovation process(es), the territory now has a legacy 'consisting of the memory of successful past situations of coordination, the trust between the actors that results, as well as specific cognitive resources that are virtually complementary (able to be combined to solve future production problems)' (Colletis and Pecqueur, 2005). This can then lead to a new form of qualification of the product, or even new products and/or new know-how, potentially leading to a new LAFS configuration (new networks or even new actors, including the possibility of withdrawal of some initial actors).

There therefore exist LAFS, localized production systems or clusters 'that win'[22], i.e., that are able to sustain a capacity for innovation and are able to innovate continuously to face new competition (Courlet, 2002; Porter, 1998), while other systems disappear. In this context, is it possible for support organizations to intervene to strengthen coordination between actors and to build up their capacity for collective action and innovation?

\section{What sort of support can be provided to actors in localized agrifood systems?}

There are two possible postures that can be adopted for supporting the dynamics of innovation in localized agrifood systems (LAFS):

- we can, first of all, assume that innovation systems can only originate from endogenous dynamics, i.e., that innovation processes are essentially based on coordination between actors connected by different forms of historical proximity; it may thus seem difficult, if not impossible, to attempt to (re)construct this proximity and these interactions through an exogenous intervention (Martin and Sunley, 2003);

- another posture, adopted by many support organizations, is to attempt to 
(re)build or reinforce the mechanisms for enabling and fostering collective action at a local level; to this end, we can rely on the theoretical frameworks for analysing collective action (Ostrom, 2010) to support the (re)construction of institutions that can promote coordination between actors and enable them to activate new common resources (Boucher, 2004).

The effectiveness of external support has been demonstrated in many cases of European industrial districts, with this support making it possible to perpetuate territorial dynamics and cooperation between actors (Schmitz and Musyck, 1994). However, the creation and use of tools for development based on analytical concepts such as clusters has come in for some criticism. How to define the actors who are part of the system and those who are not, what spatial perimeter to use, which activities to include, what types of support to implement (Martin and Sunley, 2003)?

Aware of these difficulties, but also of the wider issues involved, researchers and practitioners[23] have chosen the LAFS model to construct an intervention framework. This model represents an alternative to diffusionist models that accord too little weightage to economic actors in innovation production. It emphasizes the existence of collective strategies at a territorial scale, the capacity of actors to come together around these strategies, the benefits of cooperation between them and with support organizations, and, finally, the LAFS's ability to produce innovations that differentiate local production and its competitiveness in national and international markets. This model then makes it possible to identify levers for action to overcome situations that block collective action and to reorient the trajectories of local agrifood production systems by strengthening the dynamics of collective innovation and the product's local qualification (Muchnik et al., 2007).

Several types of actions are possible to strengthen a LAFS, including technical, organizational or institutional support for capacity building of actors and for enhancing coordination between them.

Technology transfers, often attempted by support organizations to reinforce innovation, do not always produce the expected effects (i.e. the adoption of the proposed technique by local actors) but the combination of local knowledge with other types of knowledge can lead to innovations based on local adaptations of these exogenous techniques. An apt example of such an 
adaptation is the Gloria dairy basin in Brazil. Training in good practices imparted to artisanal cheese producers, which constituted the bulk of the external intervention system, did not directly lead to the expected effects. However, the subsequent informal exchanges between these cheese makers were based around the information acquired during the training, which helped to reinforce the dynamics of innovation regarding processing methods (Cerdan and Sautier, 2002). This process of combining local knowledge with external knowledge can be supported just as effectively by means other than traditional training, such as study tours, exchanges of know-how, etc.

Technology-centred support is, however, not enough. It is also necessary to (re)establish a system of coordination between the actors and a capacity of collective action, and to promote the (re)deployment of local organizational and institutional mechanisms. There are three main ways to do so.

A first type of action is the setting up of producer organizations, which is a natural way to reinforce this coordination and to cope with new challenges, as can be seen in the example of cottonseed oil production in Bobo-Dioulasso (Box 6.1). This example also shows that the legitimization of these organizations by external actors is an important factor in raising their effectiveness (Ostrom, 2010). However, producer organizations are not always able to resolve problems concerning collective action, especially when they have been set up at the initiative of development organizations, or, as we see from the Bobo-Dioulasso example, when a jump in membership weakens their capacity of coordination.

A second type of action consists in reinforcing the coordination between actors through a stronger territorial anchoring so that public and private organizations can intervene in support of these territorial dynamics which are more inclusive than a LAFS's. In many examples, this incorporation of a LAFS into a broader strategy of territorial development has been an important factor in its (re)energization. In the case of rural cheese diaries of Cajamarca in Peru (Boucher, 2004), the LAFS's territorial anchoring was strengthened by the creation of an organization of cheese producers and other territorial actors (other agrifood businesses, service providers, nongovernmental organizations, local authorities and representatives of public institutions, etc.). From an economic point of view, this anchoring provided 
producers with new opportunities for imparting value to their products by including them in a basket of goods and services (cheese, honey, biscuits, ham, artisanal chocolate, agro-tourism, etc.) promoted collectively (advertising of the territory's attractions, gastronomic tours, etc.).

In order to produce results, this territorial coordination of a territory's different sectors through the constitution of a basket of territorialized goods and services does not necessarily require the formalization of a new organization, but does require the involvement of public and private actors (Hirczak et al., 2008) and a long-term perspective.

Finally, a third type of action involves recourse to geographical indications (GIs), which are frequently presented by their proponents as a tool for territorial development. In theory at least, they should be able to impart strength to a LAFS and to have a strong influence over its life cycle. Geographical indications limit the LAFS's spatial expansion and strengthen its actors' capacity of collective action. They do this through the creation of formal organizations (for managing the geographical indication), the increased alignment of strategies that is induced by the geographical indication's specifications, and the reduction in competition between the actors due to the new markets that the geographical indication is liable to open up (Fournier, 2008). The example of coffee production in Kintamani (Box 6.2) illustrates a case in which a geographical indication strengthens a LAFS and makes an innovation process sustainable.

\section{Box 6.2. Production of Kintamani coffee in Bali: when a geographical indication sustains the dynamics of innovation}

Farmers have been growing coffee on the island of Bali (Indonesia) since the 19th century. Until the 1990s, they used the simple dry method to process the coffee and thus obtained coffee of ordinary quality. Wet processing (including fermentation to produce coffee that is more aromatically complex) was then introduced in the Kintamani region, a mountainous area in the island's northeast. This method was first adopted by a private company sourcing coffee cherries from small growers. Starting in the 2000s, it was also adopted directly by the small growers, thanks to a Balinese government support programme that 
offered processing equipment and training to producer organizations.

The creation of this new sector for a high-quality product, which progressively accounted for $20 \%$ of local Arabica production, was a breakthrough innovation for the area. In addition to the adoption of the wet-processing technique, the sector required the establishment of new organizations and was forced to target new markets. Its growth has been achieved through the establishment of a local innovation system bringing together growers and their organizations, researchers, development actors and buyers (some of whom have provided equipment and expertise to producer organizations).

These interactions, especially between the producer organizations, have to be maintained, both for mastering the processing technique and for identifying relevant markets. Existing cooperation arrangements were significantly enhanced by the decision, in 2001, to apply for a geographical indication for Kintamani coffee. This move was an initiative of research centres and the provincial government. This ad hoc mechanism further strengthened the cohesion between producers.

However, the coordination between the growers has been put to the test several times. In 2006 and 2007, overproduction created a crisis of large unsold inventories. In such contexts, cooperation between actors often takes a back seat, but the Kintamani coffee growers were able to maintain their information exchange networks (on techniques and markets) and their collaborative strategies. The geographical indication was registered in 2008. A few years later, in 2012, in a fresh context of falling prices, this cooperation even increased, with the different producer organizations setting up a cooperative to centralize coffee sales.

Even though Kintamani's coffee growers have historically been very close to each other, in particular because of the numerous opportunities for meetings and exchanges provided by the many religious ceremonies they participate in, the geographical indication has played an important role in reinforcing this proximity and the resilience of this LAFS by creating an organizational mechanism that induces constant interactions between actors. 
The flip side of the role of geographical indications in innovation processes must, however, also be underlined. While they can, under certain conditions, reinforce coordination between actors, they can also in of themselves reduce the possibilities of innovation. The codification of technical practices in the form of specifications constrains their evolution. Some geographical indications can thus create 'museums of production' in which innovation becomes problematic (Bowen and De Master, 2011). Furthermore, geographical indications do not always reinforce the process of territorial development, as their purpose may differ. In countries new to geographical indications, some of them have indeed been used solely to pursue the growth of the sector concerned on the basis of a list of modernizing specifications that do not take into account territorial specificities, and that have remained independent of the territory's trajectory (Durand and Fournier, 2017).

\section{Conclusion: a model for thinking and acting}

The localized agrifood system (LAFS) model makes it possible to understand the innovation processes taking place in small-scale or semi-industrial agrifood production. The fundamental importance of the collective dimension and localized organizational and institutional mechanisms has been demonstrated, as well as that of relationships with actors outside of the system. The different phases of a LAFS's life cycle have been highlighted, showing that a LAFS's sustainability is not guaranteed, nor that of the innovation systems associated with it. Indeed, LAFS appear to be fragile and complex. In order to survive and flourish over time, they need to maintain a strong cohesion between their actors, but this cohesion can be threatened by the success and attractiveness of dynamics of innovation and the expansion of production systems.

The LAFS model can thus inspire development programmes aimed at strengthening the dynamics of innovation through technical support (especially through exchanges of knowledge and know-how) and/or organizational support (setting up, strengthening or legitimization of producer organizations; assembling baskets of goods and services; registration of geographical indications, etc.). Development organizations have a limited 
ability to really influence essentially endogenous territorial dynamics, but it is possible for them, through these different actions, to (re)build a framework that is conducive to collective actions.

\section{Wibliography}

Asheim B.T., Smith H.L., Oughton C., 2011. Regional innovation systems: theory, empirics and policy. Regional studies, 45(7), 875-891.

Becattini G., 1992. Le District Marshallien : une notion socio-économique. In: Les régions qui gagnent (Benko G. and Lipietz A., eds). PUF, Paris, 3555.

Benko G., Lipietz A. (eds), 1992. Les régions qui gagnent, PUF, Paris.

Boucher F., 2004. Enjeux et difficultés d'une stratégie collective d'activation des concentrations d'agro-industries rurales, le cas des fromageries rurales de Cajamarca au Pérou. Doctoral thesis, Versailles Saint-Quentin-en-Yvelines University, 436 p. + annexures.

Bowen S., De Master K., 2011. New rural livelihoods or museums of production? Quality food initiatives in practice. Journal of Rural Studies, 27(1), 73-82.

Cerdan C., Fournier S., 2007. Le système agroalimentaire localisé comme produit de l'activation des ressources territoriales. Enjeux et contraintes du développement local des productions agroalimentaires artisanales. In: La ressource territoriale (Gumuchian H., Pecqueur B., eds), Economica, Anthropos, Paris, 103-125.

Cerdan C., Sautier D., 2002. Réseau localisé d'entreprises et dynamique territoriale. Le bassin laitier de Gloria (Nordeste Brésil). In: Systèmes agroalimentaires localisés. Terroirs, savoir-faire, innovations (Moity Maizi P., De Sainte Marie C., Geslin P., Muchnik J., Sautier D., eds), Études et recherches sur les systèmes agraires et le développement, 32, Inra, Paris, 131-144. 
Chabrol D., Muchnik J., 2011. Consumer skills contribute to maintaining and diffusing heritage food products. Anthropology of food (online), 8,

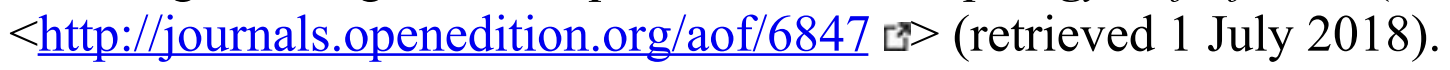

Chevassus-au-Louis B., Génard M., Glaszmann J.-C., Habib R., Houllier R., Lancelot R., Malézieux É., Muchnik J., 2008. L'intégration, art ou science ? In: Partenariats, Innovation, Agriculture, 3 June 2008, Paris, Inra-Cirad international symposium.

Colletis G., Pecqueur B., 2005. Révélation de ressources spécifiques et coordination située. Revue économie et institution, 6-7, 51-74.

Courlet C., 2002. Les systèmes productifs localisés. Un bilan de la littérature. In: Le local à l'épreuve de l'économie spatiale. Agricultures, environnement, espaces ruraux (Torre A., ed.), Études et recherches sur les systèmes agraires et le développement, 33, Inra, Paris, 27-40.

Durand C., Fournier S., 2017. Can Geographical Indications Modernize Indonesian and Vietnamese Agriculture? Analyzing the Role of National and Local Governments and Producers' Strategies. World Development, 98, 93104.

Fournier S., 2002. Dynamiques de réseaux, processus d'innovation et construction de territoires dans la production agroalimentaire artisanale. Études de cas autour de la transformation du gari de manioc et de l'huile de palme au Bénin. Doctoral thesis, Versailles Saint-Quentin-en-Yvelines University, 325 p. + annexures.

Fournier S., 2008. Les indications géographiques : une voie de pérennisation des processus d'action collective au sein des Systèmes agroalimentaires localisés ? Cahiers Agricultures, 17(6), 547-551.

Fournier S., Muchnik J., 2012. El enfoque « SIAL 》 (Sistemas Agroalimentarios Localizados) y la activación de recursos territoriales. Agroalimentaria, 18(34), 133-144.

Fournier S., Muchnik J., Requier-Desjardins D., 2005. Proximités et efficacité collective. Le cas des filières gari et huile de palme au Bénin. In: 
Proximités et changements socio-économiques dans les mondes ruraux (Torre A., Filippi M., eds), Éditions Inra, Paris, 163-180.

Gallaud D., Martin M., Reboud S., Tanguy C., 2012. Proximités organisationnelle et géographique dans les relations de coopération : une application aux secteurs agroalimentaires. Géographie, économie, société, 14(3), 261-285.

Geels F. W., 2014. Reconceptualising the co-evolution of firms-in-industries and their environments: Developing an inter-disciplinary Triple Embeddedness Framework. Research Policy, 43(2), 261-277.

Geels F.W., 2004. From sectoral systems of innovation to socio-technical systems: Insights about dynamics and change from sociology and institutional theory. Research policy, 33(6), 897-920.

Hirczak M., Moalla M., Mollard A., Pecqueur B., Rambonilaza M., Vollet D., 2008. Le modèle du panier de biens. Économie rurale, 6, 55-70.

Hounkonnou D., Kossou D., Kuyper T.W., Leeuwis C., Nederlof E.S., Röling N., Sakyi-Dawson O., Traoré M., van Huis A., 2012. An innovation systems approach to institutional change: smallholder development in West Africa. Agricultural systems, 108, 74-83.

Martin R., Sunley P., 2003. Deconstructing clusters: chaotic concept or policy panacea? Journal of Economic Geography, 3, 5-35

Muchnik J., Requier-Desjardins D., Sautier D., Touzard J.-M. (eds), 2007. Dossier Systèmes agroalimentaires localisés. Économie et Sociétés, Série Systèmes alimentaires, AG, 29(9), 1465-1565.

Muchnik J., Sautier D ., 1998. Systèmes agroalimentaires localisés et construction des territoires, document de travail, ATP SYAL, Cirad-Tera, Montpellier, $46 \mathrm{p}$.

Nelson R., Winter S.G., 1982. An Evolutionary Theory of Economic Change. Belknap Press, Harvard University Press, Cambridge (Mass.), 454 p. 
North D.C., 1994. Economic Performance Through Time. American Economic Review, 84(3), 359-368.

Ostrom E., 2010. Beyond markets and States: polycentric governance of complex economic systems. American Economic Review, 100(3), 641-72.

Pecqueur B., Zimmermann J.B. (eds), 2004. Économie de proximités. Hermès, Lavoisier, Paris, 264 p.

Porter M., 1998. Clusters and the new Economics of Competition. Harvard Business Review, Nov-Dec, 77-90.

Prévost P., Capitaine M., Gautier-Pelissier F., Michelin Y., Jeanneaux P., Fort F., Javelle A., Moity-Maïzi P., Leriche F., Brunschwig G., Fournier S., Lapeyronie P., Josien E., 2014. Le terroir, un concept pour l'action dans le développement des territoires, VertigO, la revue électronique en sciences de l'environnement [online],

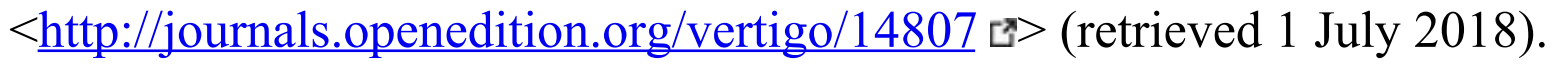

Schmitz H., Musyck B., 1994. Industrial Districts in Europe: Policy Lessons for Developping Countries? World Development, 22(6), 889-910.

Schumpeter J.A., 1934. The theory of economic development: an inquiry into profits, capital, credit, interest, and the business cycle. New Brunswick, New Jersey: Transaction Books. (Translated from the 1911 original German, Theorie der wirtschaftlichen Entwicklung.) .

Schut M., Klerkx L., Sartas M., Lamers D., Mc Campbell M., Ogbonna I., Kaushik P., Atta-Krah K., Leeuwis C., 2016. Innovation platforms: experiences with their institutional embedding in agricultural research for development. Experimental Agriculture, 52(4), 537-561.

Sol J., Beers P.J., Wals A.E., 2013. Social learning in regional innovation networks: trust, commitment and reframing as emergent properties of interaction. Journal of Cleaner Production, 49, 35-43.

Stuck J., Broekel T., Revilla Diez J., 2016. Network Structures in Regional Innovation Systems. European Planning Studies, 24(3), 423-442. 
Torre A., Tanguy C., 2014. Les systèmes territoriaux d'innovation : fondements et prolongements actuels. In: Principes d'économie de l'innovation (Boutillier S., Forest J., Gallaud D., Laperche B., Tanguy C., Temri L., eds), Peter Lang, Business and Innovation collection, Brussels.

Van Rijn F., Bulte E., Adekunle A., 2012. Social capital and agricultural innovation in Sub-Saharan Africa. Agricultural Systems, 108, 112-122.

\title{
Chapter 7
}

\section{Territorial innovation in the relationships between agriculture and the city}

\author{
Christophe-Toussaint Soulard, Coline Perrin, Françoise \\ Jarrige, Lucette Laurens, Brigitte Nougarèdes, Pascale \\ Scheromm, Eduardo Chia, Camille Clément, Laura \\ Michel, Nabil Hasnaoui Amri, Marie-Laure Duffaud- \\ Prévost and Gerardo Ubilla-Bravo
}

Summary. The concept of territorial innovation is used in the literature to analyse centre-periphery relationships, the quality of the environment and the territorial governance. Our research uses this concept to apprehend the multiple dimensions of relationships between agriculture and the city, and thus to understand the transformations of agriculture in the context of an urban society. To this end, we analyse social, spatial and organizational arrangements in local agri-urban initiatives. Starting from the history of the recent integration of agriculture in urban planning and local policies, we use the example of Montpellier to illustrate how these 'agri-urban' arrangements are sources of territorial innovation. In fact, innovation becomes territorial through the accumulation of micro-changes, which end up influencing established practices, uses and norms that regulate city-agriculture relationships. This process of scaling up opens up new research perspective on the relationships between territorial innovations and global transitions. 
An analysis of the relationships between the agriculture and the city, or 'agriurban'[24] relationships, helps apprehend the transformations of agriculture in the context of urban society. After several decades of the expansion of the corporate food regime, these relationships have become frayed. Cities have spread spatially by ignoring the agricultural and food issue (Steel, 2013). This disconnect between the urban and the agricultural is at the origin of a series of dysfunctions of which society is gradually becoming aware. On a global scale, recent studies have emphasized the expectations and adaptations necessary to make the agrifood system more sustainable, showing that neither the 'fully local' nor the 'fully globalized' scenarios are sustainable. At the regional and national levels, the principles of sustainable development are leading to the incorporation of environmental and food security issues in the drafting of public policies. At the local level, a multiplicity of initiatives and movements are militating for the relocation of agriculture and food production, especially in and around cities. In this context of a 'new food equation' (Morgan and Sonnino, 2010), what are the new modes of organization of agriculture and urban food systems?

Relationships between agriculture and the city encompass several dimensions: agriculture and food issues, urban planning, public health, and environmental protection. These relationships involve actors who operate according to different temporalities, rationales and values, and at different scales. The approach by territorial innovation aims to make sense of this complexity. Indeed, the concept of innovation focuses on the new agri-urban arrangements. These arrangements can be at the origin of innovations which, little by little, end up influencing the established functioning of the uses and norms that regulate city and agriculture within a territory. It is this process of change that we call territorial innovation.

How does the concept of territorial innovation help us understand the relationship between agriculture and cities? What does it tell us about the actors, the territories and the dynamics at work? Which method allows us to identify and describe these innovation processes? This chapter addresses these questions. In its first part, we argue the interest in studying innovations that link the urban to the agricultural. We define the concept of territorial innovation according to the literature. In the second part, we illustrate how the city and agriculture are connected, based on a case study of the city of 
Montpellier in southern France. In the conclusion, we suggest a research perspective for future work.

\section{Werritorial innovation: conceptual and methodological framework}

The concept of territorial innovation makes it possible to explore the relationship between innovation and territory. There exist two schools of thought in this regard. The first focuses on innovative territories and the second on the territorialisation of innovations. We follow this latter school by considering the territory as a socially appropriated space, subject to political and social issues.

\section{Existing research on city-agriculture relationships with regard to territorial innovation}

The literature on city-agriculture relationships covers four main fields of study: urban and peri-urban agriculture; agricultural land and urban planning; urban food supply; and urban policies.

Research on urban and peri-urban agriculture examines the forms of agriculture present in the cities and on their peripheries. While all the researchers concerned highlight the difficulties in defining these two terms (Nahmias and Le Caro, 2012), the majority of them focus on intra-urban agriculture (mainly urban gardens and market gardening) and on its contributions to urban sustainability. They identify the various forms of intraurban agriculture as well as the actors who undertake them, and they evaluate the techno-economic models to which these forms belong. The innovative dimension of these forms of intra-urban agriculture is based on their novelty, or their rediscovery, at the technical, organizational and social levels. These forms are different from those of peri-urban agriculture. While the dynamics of the latter mainly pertain to the agrifood sector, they are also influenced by urban expansion, land dynamics, and by the commercial opportunities they create in terms of short food supply chains and socio-ecosytems services. 
While the issue of innovation is ever present in studies on intra-urban agriculture, it is less so for peri-urban agriculture, mainly because the transformations that take place here - in practices, profiles of the actors and agricultural activities (Poulot, 2010) - are less radical, with changes in modes of production being more incrementally adaptive than disruptive.

Studies on agricultural land and urban planning normally focus on the preservation of peri-urban agricultural areas so that advantage can be taken of their multifunctionality. Researchers evaluate and compare planning tools, and analyse conflicts of land use in peri-urban agricultural areas (Chia, 2013). They analyse experiments of including agricultural buildings in urban planning (Nougarèdes et al., 2017). The status of these spaces remains unclear, between public space and private space, between individual uses and common goods (Clément and Soulard, 2016). Territorial innovation then refers to a choice between new planning decisions and local social dynamics.

The topic of urban food supply is eliciting growing interest (Viljoen and Wiskerke, 2012). The research community is developing urban planning schemes that integrate agriculture, nature and food. The innovation concerns architecture and the landscape as much as it does the economic and social aspects. Other research studies highlight the role of citizen movements in the emergence of local food concerns, especially in the pursuit of greater social justice (Reynolds and Cohen, 2016). They identify practices and innovation pathways that can trigger a transition to sustainable food strategies.

Studies on the inclusion of agriculture and food issues in urban policies make use of umbrella concepts such as the agri-urban system or urban food planning (Steel, 2013; Morgan, 2009; Viljoen and Wiskerke, 2012). Transversality and territoriality are indeed intrinsic characteristics of the governance of agriculture and food. Territorial innovation lies in the construction of new local political arrangements and new modes of territorial governance (Rey-Valette et al., 2014).

Thus, city-agriculture relationships renew the interface between the urban and the rural, agriculture and food, the implementation of urban planning and territorial development strategies. 


\section{Territorial innovation: a combination of social, spatial and organizational arrangements}

In analysing the relationships between innovations, spaces and territories, authors usually follow one of three currents of thought.

The first focuses on centre-periphery relationships. For example, the new geographical economy (Krugman and Obstfeld, 2006), originating from the spatial economy, relies on agglomeration economies to explain the polarization of places of innovation. According to this theory, the density and diversity of economic agents at the local level provide external benefits to the enterprises concerned. This is why cities are keen to implement local policies to create 'innovation ecosystems'. As a counterpoint to these studies, Giraut (2009) has conducted research on the dynamics specific to rural areas, located thus on the outskirts of these agglomeration centres. According to him, the outskirts offer spaces of freedom from the dominant norms. Some organizational arrangements between actors and resources are conducive to organizational and institutional inventiveness. For example, to adapt to competition for peri-urban land, farmers innovate by introducing nomadic farming systems adapted to land insecurity (Soulard, 2014). This reading is very interesting for the study of peri-urban areas, seen as an intermediate space between the city and the countryside, called 'third space' by Vanier (2002), where new territorialities, neither urban nor rural, are being constructed. Territorial innovation is born here from the encounter between different social worlds, in particular between the agricultural world and the urban world. It is based on socio-spatial arrangements that create new territorialities (Giraut, 2009).

The second current is based on work in regional sciences and economic geography. It focuses on the natural and human resources of a territory, and on the innovative effects of proximity between actors. Research studies focus on different territorial innovation models (Moulaert and Sekia, 2003), such as industrial districts, local productive systems, innovative environments, localized agrifood systems, alternative food networks (see Chapter 6). These studies all consider the territory as a place of resources, which offers geographical proximity and specific organizational capacities to reinforce the territorial anchoring of enterprises or products. Innovation becomes territorial 
through the links created between the actors to activate and mobilize multiple resources, derive value from them, and thus produce 'territorial innovation systems' (Torre and Tanguy, 2014). Innovation is seen as the driving force behind territorial development, in which conflicts can lead to new forms of cooperation (Torre, 2015). Transposed to city-agriculture relationships, innovation brings together resources and actors that hybridize the agricultural and the urban.

Finally, the third current of thought focuses on the institutional and political innovations generated by the territory's administration. For example, the decentralization of the National State produces new administrative territories. These decouplings modify the modes of governance, with the actors concerned having to coordinate increasingly nested levels of intervention. At the same time, new forms of public participation in political decision-making are being promoted (Douillet et al., 2012). Territorial innovation then originates from the construction of new political spaces, especially at emerging territorial scales (grouping of municipalities, metropolitan regions), and in the modes of governance and project engineering encouraged by local authorities. The administration of food and agriculture leads to the invention of new instruments of public action.

These approaches show that territorial innovation is a process of change based on three main drivers: spatial and political relationships, activation of resources, and configurations of actors.

\section{'Place-moments' of innovations and 'space-times' of territories}

City-agriculture relationships are part of a dynamic of continuous change. From a territorial innovation perspective, their study requires a focus on particular places and moments that are strategic for the actors. Fontan (2008) calls these situations 'place-moments'. That means a spatial and temporal reading of the innovation process.

From a spatial point of view, it is a matter of identifying the places where novelties emerge and the scales of their deployment. Innovations result from 
new initiatives that may emerge in a specific place, just as they may be the result of an actor operating on an all-encompassing scale and leading to multiple local translations. Innovation's territorial dimension can be apprehended through these relationships between local levels and encompassing levels, and between bottom-up rationales and top-down ones. Our comparative analyses between countries emphasize the need to consider both large scales (national or supranational) as well as small ones (municipality, neighbourhood, farm) to identify and analyse these territorial innovations (Banzo et al., 2016). In each case, the territories of action are different: metropolitan areas, municipalities, inter-municipalities, development zones, agricultural production basins, project territories, etc. Describing the process of innovation will require the qualification of the different spaces that the city-agriculture relationships act upon, from large metropolitan areas to agricultural interstices embedded within the urban environment (Laurens, 2015; Perrin and Soulard, 2014).

From a temporal point of view, studying an innovation consists of focusing on particular moments: not only at the moment when a novelty emerges, often at the initiative of an actor or a small group, but also at those when the process stops, transforms or deploys. These novelties can fizzle out or be transformed, generate conflicts, or stimulate cooperation (Torre, 2015). However, the novelty's temporal markers are not the same as those of the territory concerned. Novelties emerge during short periods while territories are transformed over much longer time spans since they retain the accumulated effects of past legacies. To characterize territorial innovation, one has thus to be attentive to legacies and inertias (notion of path dependence) as well as to current configurations and events that impel or block activation or implementation (notion of window of opportunity). The short periods of novelties have to be articulated with the long timelines of territories. Identifying the key moments of the novelties to relocate them in the territories' timelines is necessary to analyse the innovation situations. In practical terms, an innovation situation has to be characterized by a combination of agri-urban initiatives that interact in a territory. Studying the process of territorial innovation consists of reconstructing this situation from its origins to its various deployments in space and time. The method chosen to perform this longitudinal monitoring of an innovation process is to tell the story of the situation, its transformations and its effects at different scales, 
with the help of a description tool called 'dispositiff25] chronicle'(Paoli and Soulard, 2003).

\section{Wrom agri-urban initiatives to territorial innovation: the case of Montpellier}

Montpellier is a city in southern France of 270,000 inhabitants that is experiencing strong growth. Its urban area extends over more than 100 municipalities with a total of 550,000 inhabitants. The relationship between the city and agriculture has changed over time. Perrin et al. (2013) distinguish three distinct periods. Until the 1960s, Montpellier was a wine city, living on income from vineyards and the wine and spirits trade. This organic link between the city and agriculture then became increasingly frayed. From the 1960s to the 1990s, Montpellier experienced a boom of the tertiary economy and turned its back on agriculture. Viticulture also suffered from several market crises, which accelerated its decline in favour of urbanization. Since the 2000s, several changes, local and global, have contributed to a reconnection between agriculture and the city.

Research conducted in Montpellier illustrates how agri-urban initiatives are developed and deployed within a metropolitan area. It illustrates two phases of change of city-agriculture relationships. First, a phase during which territorial innovation emerges from a new conception of sustainable urban planning, breaking with existing ones, followed by a second phase in which territorial innovation has been driven by a new local food policy.

\section{Innovating through territorial management: agriculture in urban planning}

A first major development was the inclusion of the issue of agriculture into urban planning. In Montpellier, the creation in 2001 of the 'Communauté d'Agglomération'[26], initially grouping 38 municipalities in the urban area, led to the implementation of the first French Scheme for Coherent Territorial Development (French acronym: SCoT[27]). This comprehensive plan 
specified the development guidelines for the next ten years. In Montpellier, as elsewhere in France, the implementation of SCoTs was a novelty. A SCoT reflects both the willingness of the French State to devolve the prerogatives of spatial planning to local governments and an injunction to these same governments to emphasize planning in an inter-municipal perspective, thus creating a favourable context for local innovation.

The Montpellier experiment was at the heart of a new concept in urban planning, involving a complete reversal of perspective. Urban planners in charge of the SCoT pursued development no longer in terms of urban infrastructures but on the basis of natural and agricultural spaces defined from a cartography carried out by researchers (Jarrige et al., 2006). The new value accorded to open spaces, previously perceived by urban planners as blank areas to be filled, encouraged this reversal of perspective, which now placed natural and agricultural areas at the heart of the urban territory project. This innovation has since spread to many SCoTs across France. However, while this new approach has allowed the Montpellier agglomeration to define urban growth boundaries and protect farmlands, it has not been able to stop the decline of agriculture, nor has it met expectations from peri-urban agriculture regarding the urban landscape and local food supply.

At the same time, the Montpellier region, faced with urban sprawl, was subject to a strict enforcement of the new national legislation reinforcing the protection of farmlands by reducing the derogatory building rights granted to farmers. This engendered conflicts between the agricultural profession and the State, and led to the creation of a department-wide negotiation authority, the Urbanism and Agriculture working group. This unprecedented initiative served as a model for generalizing these working groups at the national level in 2008 (circular DGFAR/SDER/C2008-5006, known as the 'Barnier circular'). At the local level, the Urbanism and Agriculture working group created a new concept, that of the 'agricultural hamlet', which consists of grouping agricultural constructions within subdivisions in continuity with the villages concerned and, in this way, reducing construction in agricultural zones that fall within the ambit of local urban plans. This option was included in Montpellier's SCoT (approved in 2006) and a dozen or so agricultural hamlets came up in ten years in Hérault department. This agricultural subdivision model, however, is struggling to disseminate because its 
implementation is complex. Other more flexible forms of grouping are thus being devised by local elected officials to manage the coexistence of residential and agricultural activities (Nougarèdes et al., 2017).

In addition to the protection of agricultural land, Montpellier's SCoT also defined another planning mechanism to support agricultural development in line with urban demand: the 'agripark' (or agricultural park). This term defines a space that combines several functions: agricultural production, food supply for the city, preservation of undeveloped landscapes, leisure and environmental education for city-dwellers. The purchase of an area of 190 ha by the Communauté d'Agglomération of Montpellier in 2010 led to the creation of a first agripark and the allotment of plots of land to about 20 farmers. However, most of these beneficiaries practice conventional farming, without any new contributions to the multifunctionality expected by the local government. Only a market gardener and the members of an organicproduction cooperative nursery undertake direct sales. This situation is the result of negotiations between the community and the agricultural actors. It is revelatory of the local power that actors practising viticulture and cultivating field crops have, with their production oriented towards exports, while agriculture oriented towards the city and short supply chains remains far smaller (Jarrige and Perrin, 2017).

These local experiments revealed several characteristics of the territorial innovation. The new perspective proposed by the SCoT turned out to act as an organizational myth (Vitry and Chia, 2016), which succeeded in making many believe that an urban territory might be managed by its green belt. Even though it does not represent the reality, this novelty has grown in strength: it has spread nationally and is driving other local initiatives. The relationship between centre and periphery in the process of innovation may be observed, between the local and national levels, and between the urban centre and the rural periphery. At the local level, the results obtained with the agricultural hamlets and the agripark illustrate the disconnect that can exist between an initial project and the actual course of action resulting from negotiations between stakeholders. The interplay among actors leads to local adaptations of the initial project that reveal the power of the dominant actors. These local arrangements produce unequal results, as public resources can be captured by a minority of farmers and owners belonging to the wine sector. 
Territorial innovation does not always succeed in redistributing resources equitably or in stimulating agricultural development in line with urban demands. These examples show that this first phase of territorial innovation is limited to an institutional dimension of the city-agriculture relationship: land planning.

\section{Innovation through territorial development: including agricultural and food issues in policies}

A new political team was elected in 2014 to lead the Montpellier city-region (named 'Montpellier Méditerrannée Métropole' in 2015). Among the new strategic orientations set by elected officials was an agroecological and food policy designed with the support of the research community. This policy's ambit included divisions of the local government pertaining to the economy, planning, land, water, transport, waste, social cohesion, urban matters and communications. This transversality of the policy is also a source of its fragility since, without a dedicated administrative department, agroecological and food policy remains dependent on the elected officials' goodwill.

The implementation of the agroecological and food policy can be described as territorial innovation at the organizational level, because it induces new arrangements between the various divisions of the inter-municipal establishment and between the different municipalities within the Metropolis's territory (31 municipalities). Are we witnessing new dynamics of development on the ground? Two new actions of the Metropolis provide an answer.

A first action concerns the use of public land to set up farms that will function as part of short supply chains. While the intention is the same as for the agripark (see above), the approach used is different. Here, the land is used to set up small scale farms called 'fermes nourricières' (nourishing farms), defined by the Metropolis as small farms that rely on the principles of agroecology for farming. The communities invested in the recruitment of project leaders. In 2017, two farms were set up and the Metropolis offered support to other such farms set up by municipalities or local management bodies. The process is slow, and, as of now, concerns only a small surface 
area (around ten hectares), but it is impelling a recomposition of the agriculture of the Metropolis.

A second action focuses on citizen participation in the formulation of agroecological and food policy. Following an inventory of agricultural and food initiatives in the Metropolis area (more than 400 were identified with the support of the research community), a collaborative platform was envisaged to exchange information and experiences, and to bring together the actors of the voluntary sector around agroecological and food policy. The relationships, sometimes tense, between the Metropolis, the municipalities and the non-profit organizations are however leading to a delay in the implementation of the platform project. Multi-stakeholder working groups have therefore been constituted to discuss a joint-action agroecology strategy. After a year of discussions, agroecology was chosen as a mobilizing theme. As a flagship action, an agroecology month was organized, consisting of various events held at the initiative of the Metropolis, its municipalities and non-governmental actors (one of the latter was selected and funded to coordinate the event the following year).

The city-agriculture relationship in Montpellier is right now at a new stage. Territorial innovation is here not only political (development of a territorial policy), but also institutional (new internal skills and recourse to new external experts), experimental (new knowledge networks) and social (citizen participation).

These novelties are however fairly recent. The transformations they engender are reversible and their magnitudes remain uncertain. This situation of openness and uncertainty presupposes new cooperation and partnerships between public actors and civil society for the adoption and the implementation of a participatory policy and its institutionalization over time. To this end, actors involved in these situations will have to learn new ways of territorial governance, i.e., 'processes that allow the territory's actors to produce a shared vision, develop a strategy and to legitimize collective action' (Vitry and Chia, 2016). In Montpellier, this new way of governance is still emerging. Compared to the previous phase, territorial innovation has become much more complex, mobilizing a wider network of actors, going beyond the traditional one-on-one interactions between the State and the wine 
sector. New elected officials, new non-governmental actors and new private operators, proponents of a different model of agricultural development are arriving on the scene. Innovation is being territorialized through the creation of a way of governance that is attempting to build an urban food system specific to the Metropolis. However, these agri-urban dynamics remain marginal (including in terms of resources mobilized) within urban development and the agrifood sector. Will this movement remain marginal and eventually fizzle out? Or will it, on the contrary, drive a transition towards a sustainable agri-urban system?

\section{Conclusion: the dynamics of territorial innovation}

The example of Montpellier shows that territorial innovation emerges from the encounter between a multiplicity of agri-urban initiatives and a wider process of inclusion of agriculture and food issues in urban policies (Michel and Soulard, 2017).

The temporality associated with territorial innovation is both long and stuttering. The slow speed of changes and difficulties observed arise from the resistance, both by the city as well as the agrarian system, representing the territories's long timelines and the effects of path dependence. But the initiatives and the changes of context testify to an effective reconfiguration of the relationships between actors who, only 15 years ago, hardly knew each other. City-agriculture relationships, and the innovations they engender, also reveal the importance of social equity issues in the governance of agricultural land. The risk of instrumentalization of agriculture in urban projects remains clear, while the risk of exclusion of innovative forms of agricultural remains significant in the face of entrenched sectoral agricultural forces. While a rebalancing of city-agriculture relationships remains an integral aspect of territorial innovation, it cannot however be achieved without evaluating the issues of social, environmental and food justice (Tornaghi, 2017).

Territorial innovation thus presents itself as a path strewn with hazards, on which progress is made in fits and starts. One question remains unanswered: Which agri-urban innovations are successful, in the sense of being able to 
enhance the sustainability of the agri-urban system? This process of scaling of innovation, i.e. the mechanisms for the appropriation of novelties acquired by actors who are able to transpose them and legitimize them at higher levels, opens up a field of research on the relationships between territorial innovation and global transition. Identifying, analysing and testing mechanisms for the deployment, transposition and institutionalization of innovations at different scales can form the agenda for future research on city-agriculture relationships.

\section{Bibliography}

Banzo M., Perrin C., Soulard C.-T., Valette E., Mousselin G., 2016. Rôle des acteurs publics dans l'émergence de stratégies agricoles des villes. Exemples en Méditerranée. Economia e società regionale, XXXIV(2), 8-30.

Chia E., 2013. Conclusion. Repenser la gestion foncière : la gouvernance foncière au prisme de ses instruments, In: Terres agricoles périurbaines : une gouvernance foncière en construction (Bertrand N., ed.), éditions Quæ, Versailles.

Clément C., Soulard C.-T., 2016. La publicisation des espaces agricoles périurbains dans le Lunellois, Languedoc : un cadre d'analyse en géographie. Annales de Géographie, 6(712), 590-614.

Douillet A.-C., Faure A., Halpern C., Leresche J.P., 2012. L'action publique locale dans tous ses états : différenciation et standardisation. L'Harmattan, Paris, $353 \mathrm{p}$.

Fontan J.-M., 2008. Développement territorial et innovation sociale : l'apport polanyien. Revue Interventions économiques [online], 38, 2008, made available online on 16 February 2011, $<\underline{\text { http://interventionseconomiques.revues.org/369 }} \quad \forall>\quad$ (retrieved 23 May 2018).

Giraut F., 2009. Innovation et territoires. Les effets contradictoires de la marginalité. Revue de géographie alpine, 97(1), 6-10. 
Jarrige F., Perrin C., 2017. L'agriparc : une innovation pour l'agriculture des territoires urbains? Revue d'économie régionale et urbaine, 3, 537-559.

Jarrige F., Thinon P., Nougarèdes B., 2006. La prise en compte de l'agriculture dans les nouveaux projets de territoires urbains. Revue d'économie régionale et urbaine, 3, 393-414.

Krugman P.R., Obstfeld M., 2006. International economics: Trade and policy. $7^{\text {th }}$ edition, Addison Wesley.

Laurens L., 2015. Agri-interstice urbain ou quand l'agriculture change la réalité des marges urbaines. Bulletin de la Société géographique de Liège, $1(64), 5-22$.

Michel L., Soulard C.-T., 2017. Comment s'élabore une gouvernance alimentaire urbaine ? Le cas de Montpellier Méditerranée Métropole. In: Construire des politiques alimentaires urbaines. Concepts et démarches (Brand C., Bricas N., Conaré D., Daviron B., Debru J., Michel L., Soulard C.-T., coord.), Éditions Quæ, Versailles.

Morgan K., 2009. Feeding the City: The Challenge of Urban Food Planning. International Planning Studies, 14(4), 341-348.

Morgan K., Sonnino R., 2010. The urban foodscape: world cities and the new food equation. Cambridge Journal of Regions, Economy and Society, 3, 209224.

Moulaert F., Sekia F., 2003. Territorial Innovation Models: A Critical Survey. Regional Studies, 37(3), 289-302.

Nahmias P., Le Caro Y., 2012. Pour une définition de l'agriculture urbaine : réciprocité fonctionnelle et diversité des formes spatiales. Environnement urbain/Urban Environment, 6, 1-17.

Nougarèdes B., 2011. Quelles solutions spatiales pour intégrer l'agriculture dans la ville durable? Le cas des hameaux agricoles dans l'Hérault. Norois, 4, 53-66. 
Nougarèdes B., Candau J., Soulard C.-T., 2017. Le rapport au lieu de vie : une lecture de la cohabitation entre agriculteurs et résidents périurbains (Hérault, France), In: L'espace en partage : approche interdisciplinaire de la dimension spatiale des rapports sociaux (Bonny Y. et al., dir.). Presses universitaires de Rennes, 75-96.

Paoli J.-C., Soulard C.-T., 2003. Comment écrire la chronique d'un dispositif territorial ? Note méthodologique. RIDT seminar, 25 June 2003, Dijon, InraSad, $12 \mathrm{p}$.

Perrin C., Jarrige F., Soulard C.-T., 2013. L'espace et le temps des liens villeagriculture : une présentation systémique du cas de Montpellier et sa région. Cahiers Agricultures, 22(6), 552-558.

Perrin C., Soulard C.-T., 2014. Vers une gouvernance alimentaire locale reliant ville et agriculture. Le cas de Perpignan. Géocarrefour, 89(1-2), 125134.

Poulot M., 2010. L'agriculture comme composante de l'identité périurbaine francilienne : entre (re)connaissance et innovation. Pour, 2, 73-81.

Reynolds K., Cohen N., 2016. Beyond the Kale. University of Georgia Press.

Rey-Valette H., Chia E., Mathé S., Michel L., Nougarèdes B., Soulard C.-T., Maurel P., Jarrige F., Barbe E., Guiheneuf P.-Y., 2014. Comment analyser la gouvernance territoriale ? Mise à l'épreuve d'une grille de lecture. Géographie, économie, société, 16(1), 65-89.

Soulard C.-T., 2014. Les agricultures nomades, une caractéristique du périurbain. Pour, 224, 151-158.

Steel C., 2013. Hungry city: How food shapes our lives. Random House.

Tornaghi C., 2017. Urban Agriculture in the Food-Disabling City: (Re)defining Urban Food Justice, Reimagining a Politics of Empowerment. Antipode, 49(3), 781-801.

Torre A., 2015. Théorie du développement territorial. Géographie, économie, 
société, 17(3), 273-288.

Torre A., Tanguy C., 2014. Les systèmes territoriaux d'innovation : fondements et prolongements actuels, In: Principes d'économie de l'innovation (Boutillier S., Forest J., Gallaud D., Laperche B., Tanguy C., Temri L., eds), Peter Lang, collection Business and Innovation, Brussels.

Vanier M., 2002. Développement autour des villes. Un tiers espace voué à l'innovation. Économie \& Humanisme, 362, 53-55.

Viljoen A., Wiskerke J.S., 2012. Sustainable food planning: evolving theory and practice. Wageningen Academic Pub.

Vitry C., Chia E., 2016. Contextualisation d'un instrument et apprentissages pour l'action collective. Revue Management et Avenir, 83(1), 121-141.

14In conservation agriculture, it is the conservation of soil fertility that is the focus. According to the UN's Food and Agriculture Organization's definition of this type of agriculture, this involves maximum soil cover (by crop residues or cover crops), the absence of ploughing, a strong reduction or even an elimination of tillage, and diversified crop rotations and associations.

15This chapter is an edited version of an article we published in the journal Innovations (Chiffoleau and Paturel, 2016).

16Set out in the French law for the future of agriculture, food and forests, dated 13 October 2014 (art. 39), territorial food projects (in French: PAT, projets alimentaires territoriaux) are developed in a concerted manner on the initiative of all of the concerned territory's actors. These projects are based on a shared diagnosis, an assessment of local agricultural production and of food requirements expressed at the scale of a population area or consumption area, in terms of individual consumption as well as of collective catering requirements.

17Short food supply chain presented by its founders as a network linking direct buying communities to local producers (https://thefoodassembly.com/en $\mathbf{t}$, French version: https://laruchequiditoui.fr/fr $\left.\Xi^{\top}\right)$.

18System of trade between a producer and a group of consumers who contract to buy his produce during a season, often by paying in advance, and then receive a package of farm produce on a regular basis (http://www.reseau-amap.org/ ${ }^{*}$ ).

19Grocery store reserved for social minima beneficiaries and subsidized by the State (in French: épicerie sociale).

20The phenomenon of technological lock-in refers to the fact that when a technology has become dominant and entrenched, it is difficult to replace it, even by a more efficient or 
powerful one.

21Marshall had already described this phenomenon in his work at the end of the 19th century, writing about the 'industrial atmosphere' of industrial districts, within which 'industrial secrets cease to be secrets. They are in the air itself.'

22 Reference to the book Les régions qui gagnent [The regions that win] (Benko and Lipietz, 1992).

23This community is structured at the national level in France (creation of a LAFS scientific interest group, or SIG), then at the European level (LAFS European research group, or ERG) and at the international level (with the constitution of a LAFS network in Latin America).

24In this chapter, we use the adjective 'agri-urban' to describe the relationships of proximity between agriculture and the urban environment. It also designates intra-urban agriculture (which we sometimes also describe, more simply, as 'urban') and peri-urban agriculture.

25Dispositif is a French notion, without exact English translation, proposed by the philosopher Michel Foucault to describe an arrangement between heterogenous actors, tools, processes and controversies, implemented to control a situation or to reach a goal (authors' note).

26A 'Communauté d'Agglomération' is a metropolitan government structure in France that unites a group of towns/municipalities to work together. Communautés d'Agglomération have responsibilities that were earlier dealt with by the individual towns themselves, e.g. economic development, urban planning, garbage collection, etc.

27Schéma de cohérence territoriale. 


\title{
Part 3
}

\section{Providing support to the actors of innovation}

\section{Chapter 8}

\section{Designing and organizing support for collective innovation in agriculture}

\author{
Aurélie Toillier, Guy Faure and Eduardo Chia
}

Summary. This chapter reports on the different functions fulfilled by existing mechanisms for supporting collective innovation in the agricultural and agrifood sectors in the countries of the Global South in order to identify the potential contributions the research community can make to strengthen them. The authors show that a variety of mechanisms are needed to create enabling conditions for innovation and to provide a step-by-step support to innovation communities, according to their capacities and learning needs. Researchers are encouraged to move beyond their traditional roles of knowledge producers or trainers and work more closely with actors involved in supporting innovation. They can then generate new knowledge about innovation mechanisms themselves, helping to design and organize the support for collective innovation in a variety of situations.

In the context of developing countries where radical changes are needed in order to achieve sustainable development goals, supporting and accelerating collective innovation in the agricultural and agrifood sectors has become a central issue. However, even though innovation in agriculture has never been studied and understood as much as it is presently, there are still difficulties at the institutional and political levels to mobilize significant public or private 
investments to support innovation (Hall, 2007). Existing initiatives remain disparate, uncoordinated and low-key, and they have limited effects (TAP, 2016). Our research aims to characterize these initiatives and the support functions they fulfil in order to identify the possible contributions the research community can make to strengthen them.

Innovation is in essence a risky activity, requiring the actors to engage in a process without knowing whether it will go to its term, and where the term will exactly be. The actors come upon problems and solutions along the way, according to a pattern described by Schön (1983) as a 'conversation with the situation' that responds to them, surprises them and forces them to learn new things. Supporting innovation is therefore a complex undertaking, as each situation is unique and the outcome uncertain. Rigid protocols have only limited application and may even be counterproductive. And yet, several such mechanisms exist today, such as innovation platforms presented as turnkey approaches.

We first present the evolution of the frameworks of thought concerning innovation support in agriculture, and the types of interventions that they have led to. We then offer an overview of the range of mechanisms for supporting innovation in order to draw lessons on the nature of research that could help to improve those mechanisms.

\section{Evolution of frameworks of thought on providing support to innovation}

Garel and Mock (2016) show that innovation requires collective action and an organized environment. Two schools of thought are prominent in the field of innovation support for agricultural or rural development. The first believes in facilitation, which aims to create conditions that are conducive to innovation (Leeuwis and Aarts, 2011). The second focuses on strategic management, which involves bringing out and supervising a community of innovating actors, called innovation community, by providing support that is gradually adapted to each phase, starting from the phases for ideation and design to those for deployment and dissemination (Raven et al., 2010). 


\section{Creating conditions conducive to innovation: the contributions of systemic thinking}

In the 1950s, innovation in agriculture was essentially thought of as a phenomenon of adoption and adaptation. Science was perceived as external to the socio-economic system, independent and neutral, and a source of innovation, whereas traditional knowledge was seen as a barrier to the spread of progress. In this linear model, support for change consisted of disseminating technological novelties through extension services, which mainly targeted farmers in order to train them in these new technologies. The best-known approaches included the technology transfer method, marketdriven innovation, and the 'training and visit' system.

While this linear model of technology transfer did contribute to an increase in production and productivity in some regions of the world, it was nevertheless called into question in the late $1980 \mathrm{~s}$, following a paradigm shift from aid to development, advocating a participation-by-all approach, which is exemplified in the expression 'Farmer First' (Chambers et al., 1989). Since the beneficiaries, their objectives and their environment had to be taken more into account, it became necessary to modify the methods of intervention. With more encompassing approaches being required, the discourse among researchers and development agencies gave rise to two new frameworks of thought: AKIS (Agricultural Knowledge and Information Systems) and AIS (Agricultural Innovation Systems) (Klerkx et al., 2012). In both these frameworks, the interactive innovation model contrasts with the linear model. Innovation is thought of as a collective process of creation in which collective learning phenomena play a central role (Argyris and Schön, 1996). The farmer is no longer relegated to the role of a mere user, one who simply adopts innovation, but becomes a full actor in innovation in his own right, as a source of knowledge and a co-designer.

The AKIS framework focuses on the exchange of knowledge and information to sustain the innovation process. It is the actors of research and development, education, and agricultural advice who are at the heart of mechanisms for providing support to farmers. Participatory research methods involving farmers then followed, such as participatory research and development, participatory technology development, the Farmer First 
approach, or mechanisms for action-research in partnership (Faure et al., 2014, see also Chapter 9).

The AIS approach is intended to be even more inclusive; it takes into account all the actors who participate, directly or indirectly, in innovation processes (input suppliers, actors of supply chains, banks, policymakers, etc.). Participation, the co-creation of knowledge and value, as well as the facilitation of actor networks become the key principles for designing new mechanisms to accompany and support innovation. The main form of operationalization of this approach in the countries of the Global South is the innovation platform (World Bank, 2008). Its goal is to help different categories of actors - who usually have no connection with each other interact to share knowledge and to pool resources for innovation. Facilitation is defined as a voluntary intervention to strengthen the interactions between individuals, organizations and their social, cultural and political structures through a process of network building, social learning and negotiation (Leeuwis and Aarts, 2011).

Table 8.1 summarizes contributions systemic thinking has made in organizing support for innovation, highlighting the differences between the mechanisms that result from it, the targets of support (from the farmer to a network of multiple organizations), the intended changes (from technical change to individual or collective capacity building), the principles and methods used (from training and supervision to the facilitation of learning) and the professions of support (from the extension worker to the innovation facilitator).

Table 8.1. Contributions of systemic thinking to facilitate innovation in agriculture (adapted from World Bank, 2008, and from Hall, 2007).

\begin{tabular}{|l|l|l|l|}
\hline $\begin{array}{l}\text { Frameworks } \\
\text { of thought }\end{array}$ & $\begin{array}{l}\text { Agricultural } \\
\text { research system }\end{array}$ & $\begin{array}{l}\text { Agricultural Knowledge } \\
\text { and Information System } \\
\text { (AKIS) }\end{array}$ & $\begin{array}{l}\text { Agricultural } \\
\text { Innovation System } \\
\text { (AIS) }\end{array}$ \\
\hline $\begin{array}{l}\text { Innovation } \\
\text { model }\end{array}$ & $\begin{array}{l}\text { Linear: A process that } \\
\text { takes place in the } \\
\text { isolated and } \\
\text { controlled research } \\
\text { environment }\end{array}$ & $\begin{array}{l}\text { Interactive: A social process that originates from } \\
\text { the complex interaction of various socio-economic } \\
\text { actors }\end{array}$ \\
\hline & & & Complex, systemic, at
\end{tabular}




\begin{tabular}{|c|c|c|c|}
\hline $\begin{array}{l}\text { Innovation } \\
\text { mechanism }\end{array}$ & Technology transfer & $\begin{array}{l}\text { Co-production of } \\
\text { knowledge }\end{array}$ & $\begin{array}{l}\text { different levels and } \\
\text { multi-dimensional } \\
\text { (technical, } \\
\text { organizational, } \\
\text { methodological) }\end{array}$ \\
\hline $\begin{array}{l}\text { Vision of } \\
\text { interactions } \\
\text { between the } \\
\text { actors } \\
\text { concerned }\end{array}$ & $\begin{array}{l}\text { Sequential } \\
\text { interventions, from } \\
\text { the researcher to the } \\
\text { farmer }\end{array}$ & $\begin{array}{l}\text { Involving actors who } \\
\text { possess knowledge }\end{array}$ & $\begin{array}{l}\text { Involving actors who } \\
\text { possess the } \\
\text { knowledge and who } \\
\text { have power }\end{array}$ \\
\hline $\begin{array}{l}\text { Domains of } \\
\text { research used } \\
\text { for the design } \\
\text { of support } \\
\text { systems }\end{array}$ & $\begin{array}{l}\text { Behavioural studies } \\
\text { (on adoption) }\end{array}$ & $\begin{array}{l}\text { Knowledge management } \\
\text { Network analysis } \\
\text { Agricultural advisory } \\
\text { systems } \\
\text { Farming system }\end{array}$ & $\begin{array}{l}\text { Agency }^{(1)} \text { of } \\
\text { individuals and } \\
\text { organizations } \\
\text { Institutional } \\
\text { entrepreneurship } \\
\text { Adaptive } \\
\text { management of } \\
\text { complex systems }\end{array}$ \\
\hline $\begin{array}{l}\text { Popularized } \\
\text { methods }{ }^{(2)} \\
\text { for } \\
\text { supporting } \\
\text { innovation }\end{array}$ & $\begin{array}{l}\text { Technology transfer } \\
\text { Induced innovation } \\
\text { 'Training and visit' } \\
\text { system }\end{array}$ & $\begin{array}{l}\text { Participatory research with } \\
\text { farmers } \\
\text { Participatory technology } \\
\text { development, Farmer First } \\
\text { Action research in } \\
\text { partnership, participatory } \\
\text { rural evaluation } \\
\text { Field school, management } \\
\text { advice for family farms }\end{array}$ & $\begin{array}{l}\text { Innovation platforms } \\
\text { Multi-actor networks } \\
\text { Alliance for learning } \\
\text { Agricultural advice } \\
\text { forums }\end{array}$ \\
\hline $\begin{array}{l}\text { Principles of } \\
\text { support }\end{array}$ & $\begin{array}{l}\text { Helping a large } \\
\text { number of farmers } \\
\text { adopt new techniques }\end{array}$ & $\begin{array}{l}\text { Helping farmers participate } \\
\text { in research, training and } \\
\text { advisory mechanisms, and } \\
\text { express their needs, and } \\
\text { adapting inventions } \\
\text { designed without their } \\
\text { involvement }\end{array}$ & $\begin{array}{l}\text { Facilitating } \\
\text { interactions, } \\
\text { knowledge exchange, } \\
\text { coordination }\end{array}$ \\
\hline \multirow[t]{2}{*}{$\begin{array}{l}\text { Objects of } \\
\text { the support }\end{array}$} & $\begin{array}{l}\text { Product of the } \\
\text { innovation }\end{array}$ & Users of the innovation & $\begin{array}{l}\text { Actors who } \\
\text { contribute to the } \\
\text { innovation }\end{array}$ \\
\hline & & $\begin{array}{l}\text { Strengthening farmers' } \\
\text { capacities and the } \\
\text { functioning of farms }\end{array}$ & $\begin{array}{l}\text { Strengthening the } \\
\text { capacity to innovate } \\
\text { in all the actors and }\end{array}$ \\
\hline
\end{tabular}




\begin{tabular}{|l|l|l|l|}
$\begin{array}{l}\text { Intended } \\
\text { changes }\end{array}$ & $\begin{array}{l}\text { Improving farm } \\
\text { performance }\end{array}$ & $\begin{array}{l}\text { Strengthening support and } \\
\text { advisory services, and } \\
\text { those disseminating } \\
\text { knowledge in rural areas }\end{array}$ & $\begin{array}{l}\text { creating novelties in } \\
\text { production systems, } \\
\text { supply chains and } \\
\text { territories }\end{array}$ \\
\hline $\begin{array}{l}\text { Professions } \\
\text { of support }\end{array}$ & $\begin{array}{l}\text { Technicians/extension } \\
\text { workers of } \\
\text { government services }\end{array}$ & $\begin{array}{l}\text { Technicians/advisers from } \\
\text { the private and public } \\
\text { sectors }\end{array}$ & $\begin{array}{l}\text { Facilitators of } \\
\text { innovation }\end{array}$ \\
\hline
\end{tabular}

1. Ability to set goals and act in a consistent manner to achieve them.

2. Popularized methods are those that are labelled, i.e. they are the subject of a book or a methodological guide, have been used on a large scale in development projects, and involve the use of specific approaches and tools.

The systemic approach to innovation has been widely used by development workers and researchers (Touzard et al., 2015) and has allowed the widening of the circle of actors to be considered to accompany innovation (from the farmer to the policymaker), but it is still very rarely mobilized to design national policies and interventions to support innovation (Chowdhury et al., 2014). Interventions formulated in development projects or policy documents often suffer from a lack of operationalization; they are presented as vague principles of action (such as 'developing collective capacities to innovate'), leaving organizations that have to implement them with the responsibility of finding the right methodology to achieve the intended change (Raven et al., 2010).

\section{Managing innovation strategically: the contributions of theories of learning and of management}

Research on strategic management and learning is increasingly being used to reinforce the field of analysis of action in order to support the emergence and rise of innovation communities (TAP, 2016), and thus moderate the overly analytical knowledge generated by approaches centred on innovation systems.

The aim is to focus on actors in innovation situations and on their support 
needs, by recognizing that in the field of agricultural development, the actors are neither experienced nor trained in the collective design of innovation, nor are they used to working together towards a common goal. We define an innovation situation on the basis of the definition by Girin (2016) of the management situation. It involves, on the one hand, a community of actors undertaking activities, more or less coordinated, which contribute to developing the innovation and, on the other, physical, cognitive and relational resources that can be used to innovate. Each of these actors has a specific interest in the innovation being developed and their cooperation is guided by common goals. The complexity of an innovation situation can vary depending on the changes required at the individual and collective levels (changes in knowledge, attitudes, practices, rules) and the degree of uncertainty encountered.

As advocated by learning theories, developing individuals' innovation capacities must be the core of the accompaniment approaches being tried out. The capacity to innovate refers to the knowledge and skills a group needs to effectively use, master and improve existing resources, or create new ones, in order to innovate (Hall, 2005). It includes the ability to apprehend the situation and its environment, set goals, take risks, experiment and implement concerted actions, build relationships and alliances, and mobilize resources. It is a matter of both technical and functional capabilities (TAP, 2016).

The managerial perspective helps to establish principles of action and to create useful tools for accompaniement practitioners. By relying on the theories of adult learning (Kolb et al., 2001), it becomes possible to determine which tools to use, given the types of learning that must be generated, whether they are simple or transformative, involving changes in knowledge, attitudes, practices, rules of action or values. The tools can be diverse and may consist of, for example, a dashboard, a computer model, a field visit, a participatory workshop, a monitoring committee, or a charter. They promote learning by guiding reflection, participating in the creation of a common language, or orienting action. Each tool must be seen as part of an intervention method that makes sense of the use of the tool.

Research about innovation management draws attention to the complexity of innovation situations, i.e. to the multiplicity of the critical drivers of 
innovation at different levels, individual, organizational and interorganizational (or collective), so that action can be taken on them (Crossan and Apaydin, 2010). For example, we can compare two innovation situations: the adaptation of an agricultural technique to a particular agroecological context $v s$ the creation of a new agricultural model based on agroecological principles (Figure 8.1). In the first case, individuals or organizations need primarily to incrementally modify their practices and strategies for action, without questioning the values that guide their actions. It is a matter of simple learning, which can be supervised or facilitated through experimentation or decision-making support. In the second case, in contrast, a change in the reference framework, i.e. a change of all the representations that result from the acquired experience and that guide future experience, is required. This type of learning, called 'transformative' (Mezirow, 1991), requires a different type of support, which focuses on the capacity to make sense of collective action (i.e.'sensemaking' defined by Weick, 2001). Tools to automate the search for new ways of doing things can be used, such monitoring and evaluation tools, which foster reflective analysis and enable transformative learning within the innovation community. A high capacity to innovate will result from the ability to achieve and combine simple and transformative learning, while continuing to work and by adapting work routines (Argyris and Schön, 1996). It is such kinds of learning that will enable each individual to align better with others to achieve collective innovation (Brown et al., 2004).

Figure 8.1 illustrates different innovation support approaches depending on the one hand, on the complexity of the innovation situation and thus the types of changes required and, on the other hand, on the capacity of actors to innovate. The support methods and tools to be used vary according to the four cases. 


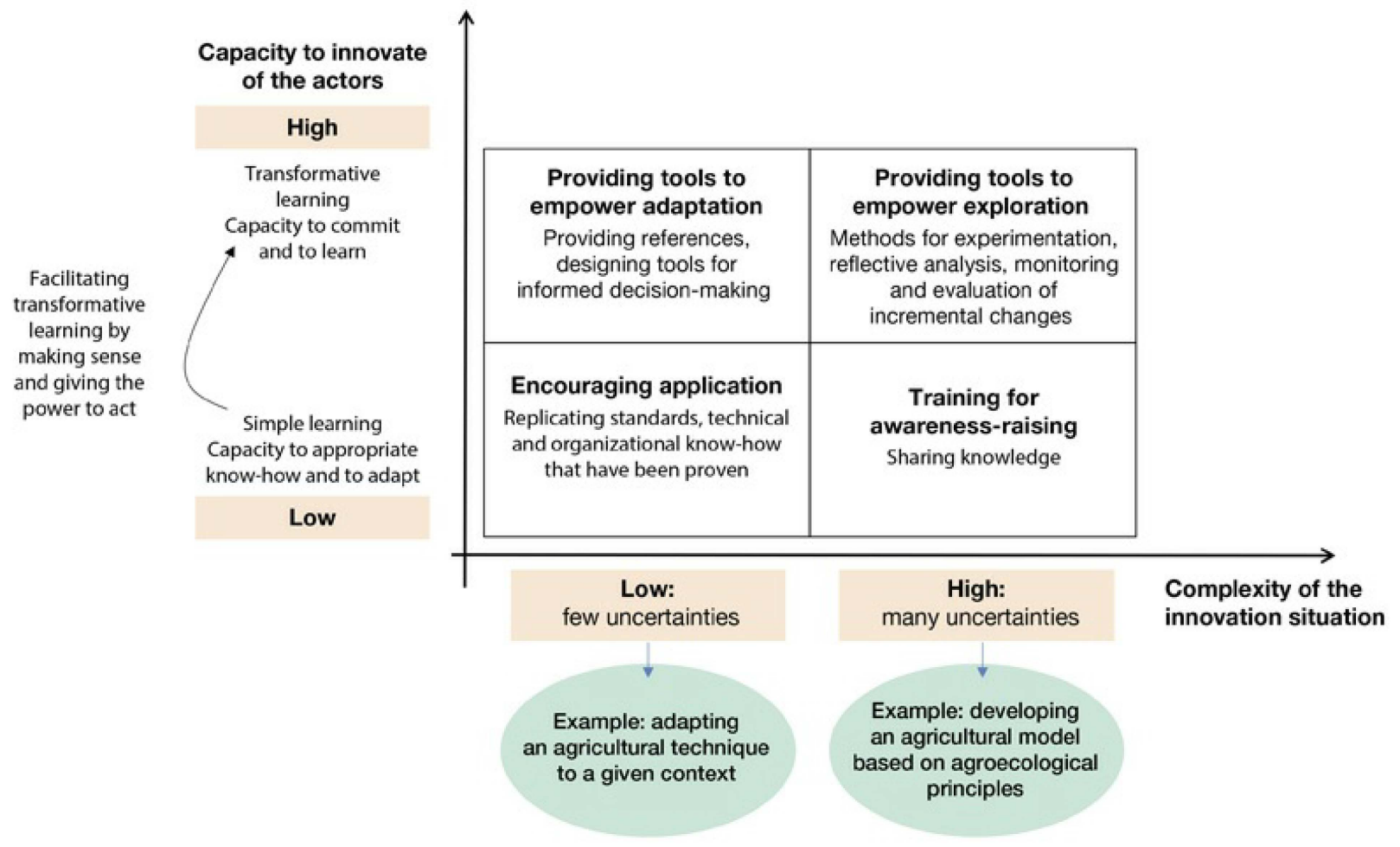

Figure 8.1. Examples of support activities during an innovation process, depending on the complexity of the innovation situation and the capacity of actors to innovate.

Dubois et al. (2016) show that managing the emergence of innovation communities is crucial in all innovation situations, especially for creating design spaces, organizing collective reflection and exchanges of ideas, identifying partners to involve, and monitoring collective activities. Furthermore, as the innovation community and the innovation itself progress, support needs evolve. The main challenge is to get the actors to understand the concepts to be explored, the knowledge to be acquired, the skills to be built up, and the actions to be carried out by a combination of planning and improvisation (Land et al., 2009). There are a significant number of failures in the processes of accompaniment since such situations involving several actors are conducive to opportunistic behaviour and disengagement by individuals and organizations if their interests are not adequately addressed (Vall et al., 2016). Strategic management must address these pitfalls, for example by accelerating certain phases of the innovation process (Cohendet et al., 2008) or by establishing formal modes of cooperation between the various actors involved (Dhanaraj and Parkhe, 2006). More specifically, the 
literature on innovation support allows us to distinguish two levels of intervention to design on and organize innovation support: the micro level of innovation situations and the macro level - sectoral, regional, or national depending on the context - in which they evolve. Innovation communities have specific support needs depending on the stages of the innovation process, the capacities of the actors involved and the complexity of the innovation situation.

\section{Diversity of support mechanisms: their emergence and sustainability in the Global South}

In this section, we illustrate the diversity of existing support mechanisms that play a role in accompanying innovation processes and examine their conditions of emergence and sustainability.

\section{Styles and functions of support}

We distinguish mechanisms based on the support functions that they fulfil with regards to innovation communities' needs, to the stages of the innovation process and according to the style of support (Table 8.2).

The style of support can be:

- supervised, i.e. intentionally led by support practitionners who manage one or more stages of the innovation process according to strategic management principles and with the aim of meeting identified learning needs;

- facilitated, through the creation of an enabling environment by helping networking and coordinatation between actors, access to various innovation support services or obtain funding.

The identified support mechanisms fulfil four major functions:

- the emergence of innovation communities through the generation of collective ideas and by making actors willing to collaborate;

- the structuring of these communities by organizing collaborative work around a common project and with a common vision;

- the creation of technical partnerships with services for supporting 
innovation thus encouraging experimentation and the development of innovation;

- the creation of strategic partnerships to allow the scaling and the dissemination of innovation through replication or its promotion at a political level by creating relationships with key actors of change.

Table 8.2. Diversity of support mechanisms in the Global South, based on the style of support and the function performed.

\begin{tabular}{|c|c|c|c|}
\hline \multirow{2}{*}{\multicolumn{2}{|c|}{$\begin{array}{l}\text { Functions fulfilled by the support } \\
\text { mechanism and examples of activities }\end{array}$}} & \multicolumn{2}{|l|}{ Styles of support } \\
\hline & & Facilitated support & $\begin{array}{l}\text { Supervised } \\
\text { support }\end{array}$ \\
\hline $\begin{array}{l}\text { Helping } \\
\text { innovation } \\
\text { communities to } \\
\text { emerge and } \\
\text { develop }\end{array}$ & $\begin{array}{l}\text { Communicating and } \\
\text { raising awareness about } \\
\text { inventions (solutions) or } \\
\text { social issues (problems) } \\
\text { Creating spaces for } \\
\text { designing } \\
\text { Stimulating the collective } \\
\text { production of new ideas: } \\
\text { exposure to new } \\
\text { knowledge, confronting of } \\
\text { paradoxes, exchanges } \\
\text { between peers } \\
\text { Organizing reflection and } \\
\text { exchanges of ideas }\end{array}$ & $\begin{array}{l}\text { Science and society } \\
\text { forum } \\
\text { (www.soscience.org) } \\
\text { Third-party areas for } \\
\text { experiments and } \\
\text { meetings: spaces for } \\
\text { coworking, FabLab } \\
\text { Competitions and } \\
\text { prizes for innovative } \\
\text { projects conducted } \\
\text { by pioneers }\end{array}$ & $\begin{array}{l}\text { Action research in } \\
\text { partnership or co- } \\
\text { design of } \\
\text { innovations by } \\
\text { research teams } \\
\text { Ways to support } \\
\text { project leaders in } \\
\text { scientific and } \\
\text { technical training } \\
\text { institutes or } \\
\text { innovation centres }\end{array}$ \\
\hline $\begin{array}{l}\text { Structuring } \\
\text { innovation } \\
\text { communities }\end{array}$ & $\begin{array}{l}\text { Promoting collaborative } \\
\text { leadership } \\
\text { Assisting with planning } \\
\text { Encouraging organizations } \\
\text { to look outside and } \\
\text { encouraging participatory } \\
\text { learning } \\
\text { Providing methods and } \\
\text { tools for exploration or } \\
\text { use }\end{array}$ & & $\begin{array}{l}\text { Projects to build } \\
\text { up the innovation } \\
\text { capacity of actors } \\
\text { Projects based on } \\
\text { the participatory } \\
\text { development of } \\
\text { innovation } \\
\text { Communication } \\
\text { agencies for } \\
\text { development, } \\
\text { which will create } \\
\text { customized tools }\end{array}$ \\
\hline & & & $\begin{array}{l}\text { Business clusters } \\
\text { in a region } \\
\text { Process to support }\end{array}$ \\
\hline
\end{tabular}




\begin{tabular}{|c|c|c|c|}
\hline $\begin{array}{l}\text { Creating } \\
\text { partnerships with } \\
\text { innovation } \\
\text { support services } \\
\text { for } \\
\text { experimentation } \\
\text { and development }\end{array}$ & $\begin{array}{l}\text { Helping formulate needs } \\
\text { for support and funding } \\
\text { Helping identify donors } \\
\text { and support service } \\
\text { providers } \\
\text { Organizing opportunities } \\
\text { for meetings between } \\
\text { supply and demand } \\
\text { Creating mutual trust } \\
\text { Helping the } \\
\text { contractualization and } \\
\text { formalization of } \\
\text { partnerships }\end{array}$ & $\begin{array}{l}\text { Technopoles, } \\
\text { integrated } \\
\text { development hubs } \\
\text { Innovation Fairs, } \\
\text { B2B }^{(1)} \text {, innovation } \\
\text { market } \\
\text { Science and society } \\
\text { forum } \\
\text { Crowdfunding } \\
\text { systems }\end{array}$ & $\begin{array}{l}\text { businesses/start- } \\
\text { ups in incubators } \\
\text { Multi-actor } \\
\text { innovation } \\
\text { platforms oriented } \\
\text { towards research } \\
\text { and co-designing } \\
\text { of innovation } \\
\text { Customized } \\
\text { support for } \\
\text { innovative } \\
\text { projects: services } \\
\text { provided by } \\
\text { private agencies or } \\
\text { associations }\end{array}$ \\
\hline $\begin{array}{l}\text { Creating } \\
\text { mechanisms for } \\
\text { exchanges and } \\
\text { coordination for } \\
\text { purposes of } \\
\text { scaling }\end{array}$ & $\begin{array}{l}\text { Identify the key actors of } \\
\text { change } \\
\text { Making them aware of the } \\
\text { benefits of innovation } \\
\text { Organizing opportunities } \\
\text { for discussions and } \\
\text { meetings with the } \\
\text { proponents of the } \\
\text { innovation }\end{array}$ & $\begin{array}{l}\text { Roundtables for } \\
\text { policies to facilitate } \\
\text { the emergence of } \\
\text { policies and } \\
\text { standards for } \\
\text { incentivizing } \\
\text { innovation } \\
\text { General public } \\
\text { forum to publicize } \\
\text { innovative } \\
\text { experiences }\end{array}$ & $\begin{array}{l}\text { Chain-specific } \\
\text { innovation } \\
\text { platform to } \\
\text { facilitate } \\
\text { coordination } \\
\text { between actors } \\
\text { Organization of } \\
\text { agricultural advice } \\
\text { for training and } \\
\text { publicizing } \\
\text { innovative } \\
\text { experiences }\end{array}$ \\
\hline
\end{tabular}

1. Business to business, i.e. commercial activities and marketing between companies.

Helping innovation communities to emerge and develop entails bringing together those who have the problems and those who have the solutions, organizing reflections and exchanges, providing tools and methods for generating collective ideas, and creating design spaces. These are activities that can be implemented byprojects of action-research in partnership, by certain types of innovation platforms or by innovation centers led by private or public institutions (technical and research institutes). More recently, there has been an increase in new spaces dedicated to the sharing of new ideas and to exploratory learning, which are open to all public categories. Examples include coworking spaces or FabLabs, often initiated by civil society or the entrepreneurial sector. 
The structuring of innovation communities must allow the community to function over time, so that new ideas can become innovation projects. Support activities can include the emergence and consolidation of leadership roles, planning or opening up of organizations for helping them to align their strategy. Support mechanisms of this type are still rare. They can sometimes be implemented by projects dedicated to capacity development.

The creation of technical partnerships with innovation support services facilitate the stages of experimentation and development, i.e. help formulate support and funding needs, and putting in contact with organizations that have suitable technical skills to design the innovation. Certain infrastructures, such as technopoles, business clusters, or events such as innovation fairs or markets, or, at a more virtual level, crowdfunding platforms, facilitate this linkage. Incubators, usually from private entities, offer tailor-made support services adapted to these types of needs.

The creation of strategic partnerships consists in identifying key actors of change, in political or economic spheres, to raise their awareness and mobilize them so that they can make available to the innovation communities the traditional support mechanisms for disseminating innovation, such as training in formal education systems and extension services. It is also a matter of mobilizing these actors to develop incentivizing regulatory frameworks.

Some mechanisms can perform multiple functions with no coordination with other types of mechanisms. For example, some innovation platforms tend to encompass all support functions without forging alliances with other complementary systems, such as incubators or existing advisory services. Thus, the incubation of innovative agrifood companies might be complementary to innovation platforms that aimed at improving the organization of production and sale of agricultural products.

\section{Actors and professions of support}

The different types of support mechanisms, as well as the nature of the innovations supported, are dependent on the kind of actors providing the 
support, i.e. whether from civil society, public services or private organizations.

Public or quasi-public mechanisms are mainly involved in the structuring and deployment of collective capacities for undertaking innovation at the territorial level; these include competitiveness clusters, technopoles, and technical and scientific training institutes. The State uses mechanisms that are usually part of a planned management of innovation by selecting the innovations deemed essential to meeting priority national challenges, such as food security, the fight against climate change, and the creation of new chains or new technologies (for example, genetically modified organisms, mechanization).

The private sector is increasingly positioning itself as a provider of customizable services, offering to support an innovation over time by responding to evolving support needs of innovation communities. Incubators for innovative businesses or for innovative collective projects in various supply chains and private agri-agencies specialized in organizing support programmes with relatively customizable toolboxes (for example, organization of events, creation of participatory videos) offer this form of support. Short- or medium-term value creation allows the funding of such services and thus determines the type of innovations supported, which generally consist of innovative productsin value chains. These support services are expensive as the skills they provide require a high level of expertise.

Civil society is involved primarily in the emergence and structuring of innovation communities, and the innovations concerned are usually 'responsible' ones, in which ethics dominate. These innovations usually focus on solving environmental and societal problems by addressing the needs of the most disadvantaged populations. While the resources available are few, they are used to create mechanisms to connect various existing initiatives, such as advocacy, forums for exchanges and virtual networks.

The implementation of these various mechanisms for supporting innovation in the agricultural sector in developing countries requires the creation of new professions and, consequently, new reference standards for skills - which remain to be developed. For the moment, it is mainly agricultural technicians 
and agricultural advisers who are mobilized, because they are known to be capable of providing support to farms and rural development activities. However, these skills are not enough. For example, the Global Forum for Rural Advisory Services (GFRAS) is seeking to promote a new adviser profile that is more versatile and open to managing groups of actors (Sulaiman and Davis, 2012). But many challenges are yet to be met. While such an adviser can be responsive to farmers' innovations, he can also be perceived by farmers or by development project actors as being overly influenced by his technical background, which may drive him to orient innovation processes towards traditional themes, such as increasing production, and thus may fail to be sufficiently attentive to the needs of innovating actors. Moreover, retraining agricultural advisers is easier said than done, as vocational training courses are still scarce and often inadequate.

The professional profiles for facilitating collective innovation are, however, beginning to emerge, especially in the context of the implementation of innovation platforms, but they are still not very formalized. It is usually the consultants or service providers hired in development projects that take on this role and are trained on an ad hoc basis by the projects. While such an option has its advantages (knowledge and capacity to manage participatory processes, neutrality and goodwill, especially towards the marginalized actors), it also has its limitations (low legitimacy compared to the actors involved in innovation situations, which makes it difficult to arouse the necessary willingness and commitment). In the context of projects, the temporary status of a majority of the innovation facilitators does not favour the continuity and reproducibility of support mechanisms. They stop their activities at the end of projects and their know-how is neither transmitted nor made permanent within an organization that had gained some visibility in the field of support. Finding ways to anchor such processes or approaches, to obtain funding for them and to find the necessary skills represent new challenges that the research community will have to address.

\section{W Implications of research on supporting innovation in the Global South}

The research community currently assumes different roles in supporting 
innovation, depending not only on the complexity of the situation, the needs expressed by actors, and its own desire to accompany innovation, but also on its own capabilities. Toillier et al. (2017) identify several possible roles: entrepreneur, translator, or expert. In the role of an entrepreneur, the researcher mobilizes and engages the various actors around an innovation project that he is promoting, and helps set up mechanisms (including platforms, networks, partnerships) to manage the innovation situation over a long enough period of time for the innovation to emerge and succeed. In the role of a translator, the researcher is involved in defining the problem and the goals of the action, in the co-design of innovation and in the strategy to manage the innovation process. However, tasks and responsibilities are shared, and traditional and scientific knowledge are accorded equal importance. And finally, in the role of an expert, he provides the specific knowledge needed to design the innovation, without seeking to participate in its management.

However, researchers can also be excluded altogether from innovation situations. For example, many development support agencies make effective use of action research, action-training-research or farmer-based research methods, by making farmers and technicians assume the roles of researchers and knowledge producers.

New fields of research need to be opened up in order to promote the emergence of professions and mechanisms for supporting innovation. To begin with, it is necessary to conduct research at the same time in the fields of human and social sciences and management sciences on the transformation of traditional support and advisory services in agriculture, in view of the desire to involve them in mechanisms for supporting innovation. Considered in a broader sense, other issues also assume importance. Under what conditions can organizations acquire innovation support skills and offer sustainable services? What roles can public-private partnerships play in these new types of services and mechanisms so that they are able to support all types of innovations, even those that do not generate profits?

Furthermore, there is a lack of sufficient knowledge on supporting innovations and this lacuna has to be addressed. Won't the cultural or organizational specificities in each country compel us to consider support in a 
particular way? How can different types of learning at the individual and organizational levels be combined in contexts in which actors do not know how to innovate together? Is an external actor always needed to facilitate or support an innovation process?

The coordination mechanisms of existing systems also need to be examined, depending on the innovation situations and innovation phases, so as to allow the creation of systems for accompanying innovation which cover all support needs.

Finally, it is a matter of producing new tools and approaches, together with the actors of support, in order to better respond to the diversity and complexity of innovation situations. This entails an operational production which, when it is part of an intervention research[28] approach, also helps produce new knowledge on the analysis of change and to carry out, with the actors, reflective analyses of support practices.

This kind of work applied in the agricultural sector in the Global South, where available resources, values and ethical concerns are different from those in the Global North, remain rare, not only because of its novelty, but also because of the difficulties in accessing data, and in ensuring the acceptance of intervention research on the management itself of the innovation by being present when the innovation is being carried out.

\section{Conclusion: towards pluralistic systems for supporting innovation}

The analysis of the evolution of thought frameworks shows that innovation support in the countries of the Global South has followed the evolution of development paradigms, which range from training farmers for technology transfers to facilitating exchanges within multi-actor innovation networks. The managerial perspective, enriched by contributions on processes of learning, makes it possible to put humans and individuals back at the centre: to support innovation is to support the actors of innovation, which implies taking interest in their abilities to learn, their progresses and their needs in order to adapt tools and support methods to the concerned stage of the 
innovation process.

The panorama of existing support mechanisms that we have painted is admittedly not exhaustive, but it does provide an insight into their diversity and can help identify gaps in systems for supporting innovation at the country or regional levels. On the one hand, some support functions along an innovation process are less developed than others. And on the other, certain functions cannot be fulfilled by the traditional actors of agricultural research and extension, making it necessary to involve new private sector entities, such as business incubators or communication agencies. This not only leads to a rethinking of the roles to be played by the private and public sectors, civil society and research entities in the provision of this support, but also of modalities of coordination between these plurality of actors in order to align services and the skills and tools to be mobilized for fulfilling each function.

The research community can contribute to a praxeology of innovationsupport[29] in agriculture by offering methods and tools that make it possible to reflect on and propose an organization of innovation support, and to develop the professions of support. The challenge is to produce knowledge on support processes themselves in order to help outline the modalities of collaboration between different organizations, create new types of support mechanisms, or mobilize various existing support mechanisms by showing the complementarities that exist between them for a given innovation situation. Theoretical frameworks remain to be built on the basis of field experiments with the actors of support, as well as on knowledge obtained from research on the management of innovation in other domains.

The chapters that follow illustrate the different roles that researchers can play in innovation (Chapter 9), the tools and approaches proposed by researchers for the design of agricultural innovation (Chapter 10), the evolution of agricultural advisory services in how they take the project of change and the farmers' capacity building needs into account (Chapter 11), and, finally, the support of multi-actor innovation by two different intervention methods (Chapter 12).

28 Intervention research aims to generate both practical knowledge useful for action, as well as more general theoretical knowledge (David, 2000). 
29 The aim is to produce a theory for supporting action: analysing the practices and their effects and, in turn, designing support mechanisms. 


\section{Bibliography}

Argyris C., Schön D.A., 1996. Organizational learning II: Theory, method and practice. Addison-Wesley, Reading, MA.

Brown H.S., Vergragt P.J., Green K., Berchicci L., 2004. Bounded sociotechnical experiments (BSTEs): higher order leaning for transitions towards sustainable mobility. In: System innovation and the transition to sustainability: theory, evidence and policy (B. Elzen, F.W. Geels, K. Green, eds), Edward Elgar, Cheltenham, 48-75.

Chambers R., Pacey A., Thrupp L.A. (eds), 1989. Farmer first: Farmer innovation and agricultural research. Intermediate Technology Publications, London.

Chowdhury A.H., Hambly Odame H., Leeuwis C., 2014. Transforming the roles of a public extension agency to strengthen innovation: lessons from the National Agricultural Extension Project in Bangladesh. The journal of agricultural education and extension, 20(1), 7-25.

Cohendet P., Grandadam D., Simon L., 2008. Réseaux, communautés et projets dans les processus créatifs. Management International, 13(1), 29-43.

Crossan M.M., Apaydin M., 2010. A Multi-Dimensional Framework of Organizational Innovation: A Systematic Review of the Literature. Journal of Management Studies, 47(6), 1154-1191.

David A., 2000. La recherche intervention, un cadre général pour les sciences de gestion ? 9th International conference on strategic management (AIMS), Montpellier, 24 to 26 May 2000, 22 p.

Dhanaraj C., Parkhe A., 2006. Orchestrating innovation networks. Academy of Management Review, 31(3), 659-662.

Dubois L.E., Le Masson P., Cohendet P., Simon L., 2016. Le co-design au service des communautés créatives. Gestion, 2016/2(41), 70-72, DOI 


\subsection{7/riges.412.0070.}

Faure G., Gasselin P., Triomphe B., Temple L., Hocdé H., 2014. Innovating with rural stakeholders in the developing world - Action research in partnership. CTA - $\quad$ LM Publishers, $224 \quad$ p. $<$ https://publications.cta.int/media/publications/downloads/1783 PDF.pdf $4>$ (retrieved 13 July 2018).

Garel G., Mock E., 2016. La fabrique de l'innovation. 2nd edition, Dunod, $256 \mathrm{p}$.

Girin J., 2016. Langage, organisations, situations et agencements. Les Presses de l'Université Laval, Quebec, 442 p.

Hall A., 2005. Capacity development for agricultural biotechnology in developing countries: An innovation systems view of what it is and how to develop it. Journal of International Development, 17, 611-630.

Hall A., 2007. Challenges to Strengthening Agricultural Innovation Systems: Where Do We Go From Here? United Nations University, Maastricht, The Netherlands. Working paper, 38, $28 \mathrm{p}$.

Klerkx L., van Mierlo B., Leeuwis C., 2012. Evolution of systems approaches to agricultural innovation: concepts, analysis and interventions. In: Farming Systems Research into the ${ }_{X X}{ }^{\text {t }}$ Century: The New Dynamic (I. Darnhofer, D. Gibbon, B. Dedieu, eds). Springer Science, Dordrecht.

Kolb D.A., Boyatzis R.E., Mainemelis C., 2001. Experiential learning theory: Previous research and new directions. Perspectives on thinking, learning, and cognitive styles, 1(8), 227-247.

Land T., Hauck V., Baser H., 2009. Capacity development: Between planned interventions and emergent processes. Maastricht, ECDPM. Policy Management Brief, 22.

Leeuwis C., Aarts N., 2011. Rethinking Communication in Innovation Processes: Creating Space for Change in Complex Systems. The journal of agricultural education and extension, 17(1), 21-36. 
Mezirow J., 1991. Transformative Dimensions of Adult Learning. JosseyBass, San Francisco.

Raven R., Van den Bosch S., Weterings R., 2010. Transitions and strategic niche management: towards a competence kit for practitioners. International Journal of Technology Management, 51(1), 57-74.

Schön D., 1983. The reflective practitioner. How professionals think in action. Basic Books, New-York.

Sulaiman R., Davis K., 2012. The New Extensionist: Roles, strategies, and capacities to strengthen extension and advisory services. Global Forum for Rural Advisory Services, Lindau, Switzerland.

TAP (Tropical Agriculture Platform), 2016. Common Framework on Capacity Development for Agricultural Innovation Systems: Conceptual Background. CAB International, Wallingford, United Kingdom.

Toillier A., Devaux-Spartakis A., Faure G., Barret D., Marquié C., 2018. Comprendre la contribution de la recherche à l'innovation collective par l'exploration de mécanismes de renforcement de capacité. Cahiers Agricultures, 27, 15002, $<$ https://www.cahiersagricultures.fr/articles/cagri/pdf/2018/01/cagri170061.pd u> (retrieved 4 August 2018).

Touzard J.-M., Temple L., Faure G., Triomphe B., 2015. Innovation systems and knowledge communities in the agriculture and agrifood sector: a literature review. Journal of Innovation Economics and Management, 2(17), $117-142$.

Vall E., Chia E., Blanchard M., Koutou M., Coulibaly K., Andrieu N., 2016. La co-conception en partenariat de systèmes agricoles innovants. Cahiers Agricultures, 25(1), 15001.

Weick K. E., 2001. Making sense of the organization. Blackwell Publishers, Oxford, $483 \mathrm{p}$.

World Bank, 2008. Agricultural Innovation Systems: From Diagnostics 
toward Operational Practices, In: ARD Discussion, Paper 38 (ARD Department, ed.), World Bank, Washington D.C.

\title{
Chapter 9
}

\section{Action research in partnership and emancipatory innovation}

\author{
Michel Dulcire, Eduardo Chia, Nicole Sibelet, Zayda \\ Sierra, Luanda Sito and Dominique Paturel
}

Summary. This chapter shows why and how researchers associate with nonresearchers actors engaged in the transformation of reality in an action research in partnership (ARP) in order to build a knowledge production mechanism with them. An action research in partnership arises from a meeting between an intention to conduct research and a desire of actors for change within the framework of negotiated partnerships. It can be seen as an innovation because it involves significant changes in research mechanisms, most notably of their governance, methods and practices. The mutual learning of the actors involved in this process improves their capacities to take decisions, explore, and act together. Thus, the actors use their empowerment for the future, which is the basis of sustainable development.

Innovation can be described as a capabilities-building process, as defined by Sen (2009), i.e., one that improves the capacity of actors to take decisions, explore and act together. As several authors (Rancière, 1991; Boltanski, 2011; Guespin-Michel, 2015) have noted, this empowerment is reflected in an improvement of the actors' autonomy, in other words in an operational, collective and individual emancipation. Indeed, in the field of science for development, participatory research is deemed to be an ethical approach (de Santos, 2009) by which a mechanism can be constructed for producing knowledge with the actors engaged in the transformation of reality (Dulcire, 1996), and not for producing knowledge about non-researcher actors or for imposing a solution designed by researchers on them. 
Linking research activities with social demand originating from farmers, support services, policymakers, supply-chain actors and consumers requires significant changes in research mechanisms and in the practices of all concerned. It is a matter of strengthening the dynamics of collective learning, in contrast with approaches built around the supervision of farmers supposedly guided solely by technical rationality.

This broadening of scope leads to the following questions:

- How to make all the actors work together?

- What role should be played by the research community?

By engaging in collective processes of action research in partnership (ARP), rural actors and researchers become partners in a process of shared research. The overall goal of the ARP is to strengthen the individual and collective capacities that drive the innovation processes of the actors involved, with a view to their emancipation. ARP fully associates farmers and other actors in a process of change, which requires interactions between the technical, social and organizational dimensions. Since their own needs and practices are included in this way of doing things - instead of only the points of view of the institutions that are providing support to them -, actors are no longer objects of study or passive beneficiaries.

The complexity of social interactions and contexts of intervention argue in favour of ARP, in which collective research and action are based on reflexive mechanisms constructed with the actors. While this research practice claims to be both ethical and methodological, it is not ideological. It positions research at the interface of knowledge production and action. The act of taking a social issue and translating it into a joint research project structures the ARP. It is a demanding approach that cannot be improvised and in which common sense is not enough. This form of research has its own paradigms, hypotheses, methods and tools, which are based on experience and a constructivist attitude.

In this chapter's first part, we present a brief state of the art of approaches that involve non-researcher actors in the production of knowledge and the design of innovations. The second part presents the work of constructing an ARP that has as its goal the emancipation of all actors, including of the most marginalized. Finally, in conclusion, we return to the functions of the ARP as 
an emancipatory approach. We illustrate our observations with two text boxes that describe implementations of ARP.

\section{A brief state of the art}

If you want truly to understand something, try to change it (Lewin, 1948).

Social science research has, at least since Lewin (1948), been developing and theorizing practices aimed at involving all actors in the construction and conduct of their mechanisms of study. Research and development, participatory research, clinical research, action research, and collaborative research are all terms that reflect this effort. Indeed, all over the world and in different situations (companies, hospitals, education, agriculture, etc.), researchers have found that their proposals are often rejected, circumvented and at best modified by non-researchers. As a result, a number of researchers wanted to better understand the reasons behind these instances of resistance to change. Thus, Lewin observed that when actors are involved from the beginning of the research process, they implement the co-developed solutions more readily. This was the birth of action research, which aims at change in addition to the production of knowledge. Its goal is thus to promote modes of democratic participation to enhance the actors' capacity to work collectively, deal with complex problems, experiment and develop shared visions of a future and desired world. One of the main outcomes of this work is the formalization of the principle that reality must be modified in order to know it better and to improve it (Freire, 2005).

This line of thought is behind the various research practices that encourage interactions between actors. Collaborative research thus makes it possible to bridge the divide between researchers and non-researchers in an aim of sharing objectives, methods and results. Participatory research, often associated with social innovation, mobilizes all the actors in the production of knowledge and therefore aims to increase their ability to acquire skills and expertise (Anadón, 2007). For its part, intervention research has the objective of solving problems for which research is deemed necessary. It is contextual and aims to produce actionable knowledge. 
Action research in partnership (ARP) refers to multi-actor collective processes at the scale of the actors' territories in order to respond to social needs that could not be met via markets and social policies (Richez-Battesti et al., 2012). It aims to make visible the invisible (de Santos, 2009) in order to build alternatives and generate knowledge on complex and interdependent physical, biological, economic, social and cultural phenomena. ARP can originate from two sources: non-researchers themselves or the research community. The engagement of local actors and researchers gives rise to a true partnership, such as those sometimes established between the State and private companies to stimulate innovation (Dhume, 2010). Farmers and their organizations thus move from being mere objects of study to being true project stakeholders. Such a partnership requires a pooling of resources, tangible and intangible, to achieve a common goal (Storup, 2013) and it aims to strengthen the capacity of all actors to act and to leverage the knowledge that each of them possesses (Bosc et al., 2015).

In a perspective that goes beyond Lewin's original approach to action research, the fostering of partnerships involves setting up new spaces for action and interaction between researchers and other actors, where a common language, projects and new practices can be developed. Each ARP implements mechanisms adapted to the specificities of the situation, depending on the problem to be addressed, the system of actors, the urgency, the uncertainties and the trajectories of internal and external relationships.

\section{The different practices and experiences of action research in partnership in agriculture}

In the agricultural field, the failure of the linear model - from researcher to extension services to producer - in which the farmer is considered to be a simple passive receiver to which the researcher transmits knowledge via advisory services, has favoured the emergence of different forms of participatory research, including ARP (Chercheurs Ignorants, 2015). ARPs in agriculture generally focus on the co-production of innovations by involving local actors as soon as possible to define the problem (Chia, 2004; Dulcire et al., 2008; Faure et al., 2014). These ARPs all have the same goal: a change in the reality where the stakeholders are actually active. The ARP thus 
originates from the meeting between an intention to conduct research and a desire for change on the part of local actors, within a framework of negotiated partnerships that allow different actors to play recognized roles and to cobuild innovations likely to better address their concerns (Faure et al., 2014). The negotiation process that is then established between the actors gives rise to a shared ethical framework, which defines the parameters of action of each of the ARP's stakeholders (Vall et al., 2016). This practice of ARP also allows the actors involved to examine the conditions that are at the origin of the problems being addressed, especially those pertaining to inequalities.

The ARP translates an epistemology that relies on an ethic of the other by questioning the position from which research is conducted (Paturel, 2010). The basis of this questioning is not decided upon a priori and arises from the heart of the ARP process itself. ARP is a way to make sense and to anticipate (Paturel, 2015); it is a constructive friction between the different rationales of the (Soulard et al., 2007). It allows the evolution of socio-technical networks (Callon and Ferrary, 2006) on which the process of change is based. It is the link between knowledge for its own sake and knowledge for action, and between the genericity and uniqueness of the research outcomes.

More concretely, ARP entails the implementation of specific activities by researchers and other actors for different expected outcomes (Table 9.1).

Table 9.1. Activities to be carried out during action research in partnership (ARP).

\begin{tabular}{|c|c|c|}
\hline & $\begin{array}{l}\text { Activities to be carried out by } \\
\text { local actors (farmers, } \\
\text { technicians, etc.) }\end{array}$ & $\begin{array}{l}\text { Activities to be carried out by the } \\
\text { researchers }\end{array}$ \\
\hline Analysis & $\begin{array}{l}\text { Identifying the actors and the } \\
\text { organizations, the know-how } \\
\text { and the phenomena involved } \\
\text { Formalizing the problems and } \\
\text { choosing together the levels of } \\
\text { analysis and action } \\
\text { Studying the possible trajectory }\end{array}$ & $\begin{array}{l}\text { Understanding the complexity of situations } \\
\text { (technical, economic, social, political, } \\
\text { scientific, cultural, legal dimensions) } \\
\text { Identifying practices and know-how of local } \\
\text { actors } \\
\text { Identifying the balances of power and } \\
\text { alliances }\end{array}$ \\
\hline & $\begin{array}{l}\text { Building ARP governance } \\
\text { mechanisms }\end{array}$ & $\begin{array}{l}\text { Building researcher teams } \\
\text { Formulating the issue identified with the } \\
\text { actors into a problem }\end{array}$ \\
\hline
\end{tabular}




\begin{tabular}{|l|l|l|} 
Action & $\begin{array}{l}\text { Fostering synergy between } \\
\text { research and development } \\
\text { Setting up experiments } \\
\text { Producing actionable knowledge } \\
\text { and consolidating know-how }\end{array}$ & $\begin{array}{l}\text { Setting up distancing mechanisms } \\
\text { (monitoring committee, etc.) } \\
\text { Communicating through documents, } \\
\text { articles; popularizing, etc. } \\
\text { Developing an engagement and enrolment } \\
\text { strategy }\end{array}$ \\
\hline $\begin{array}{l}\text { Expected } \\
\text { outcomes }\end{array}$ & $\begin{array}{l}\text { Solutions to problems } \\
\text { Learnings } \\
\text { Management of complex } \\
\text { situations } \\
\text { Capacity to acquire expertise } \\
\text { and to experiment }\end{array}$ & $\begin{array}{l}\text { Actionable knowledge and area of validity } \\
\text { Intervention methods } \\
\text { Innovations at different scales }\end{array}$ \\
\hline
\end{tabular}

The ARP approach is applied and 'involving'; it is research for and in action, in which researchers and other actors influence the course of events in a continuous manner.

\section{From innovation to emancipating partnership}

The ARP is undertaken within the framework of particular apparatuses. Foucault (1994) defines an apparatus[30] as a system of relationships established between heterogeneous elements, such as discourses, institutions, regulatory decisions, laws, scientific statements, etc. These mechanisms make it possible to construct collective strategies adapted to contexts and situations, modify the system of relationships through social and collective arrangements - and not just through rigid technical ones -, and to formalize and manage relationships between actors.

In an ARP, participants and researchers jointly define a common problem and the manner in which to address it, implement alternatives and then evaluate the results, then use them individually or collectively. They thus find themselves in a sharing attitude and enjoy relationships of equality, sometimes in deliberations and decision-making, sometimes in action. Four principles guide this partnership engagement:

- scientific knowledge is not superior to other types of knowledge, local knowledge must be taken into account effectively;

- research must lead to action, i.e. it must address a given problem; 
- research is carried out in projects (including the definition of the problems and the objectives, the implementation of actions and the evaluation of the outcomes) implemented jointly by all the actors;

- the partnership must be effective, with responsibilities negotiated and shared by the various participants.

Launching such ARP processes is a complex undertaking. Indeed, they require the mobilization of many actors and dialogue, for which researchers and the other partners are not always prepared. The partnership construction phase is crucial to an ARP; it takes time and resources. Furthermore, the conduct of this partnership must be based on flexible and modifiable contractual agreements, in which each party has designated rights and duties. In certain situations, an ARP and a classical research undertaking, oriented towards the production of technical references, can work in a complementary manner. Box 9.1 illustrates both the time taken to build a partnership and the creation of an ethical framework.

\section{Box 9.1. Action research in partnership (ARP) in Burkina-Faso}

The work we have done (Vall et al., 2016) in western Burkina Faso since 2005, in the context of various research and development projects, has enabled us to formalize the ARP approach by putting it to the test. It was a matter of modifying the reality with the farmers, livestock breeders, agricultural advisers, technicians of decentralized government ministries and municipalities through the co-conception of sociotechnical innovations.

We experimented with and implemented new cultivation techniques (combination of crops, conservation agriculture), livestock husbandry activities (dairy farming, livestock fattening, draft animals), and collective management of natural resources (drafting of land charters) and of compost production. A first organizational innovation consisted in creating a local committee that brought together a village's farmers and researchers and technicians (village consultation committee). This innovation was then fine-tuned and generalized to nine other villages, and provided inspiration to public authorities within the ambit of the national decentralization policy. 
We worked with more than ten villages and 100 farms. In a first experimental phase, in two villages, we co-designed more productive and sustainable agropastoral systems, by taking recourse to the principles of ecological intensification by (re)thinking the combination of livestock husbandry with crop cultivation at both the farm and village levels. Agropastoral field experiments with farmers were an important tool.

In general, the co-design of innovations requires the ARP to function with a long-term perspective (Figure 9.1). A first phase allows the exploration of the problem and the solutions, builds trust and enrols the actors. A second phase focuses on the co-design of innovations through the production of actionable knowledge. A third phase allows for an assessment and for the triggering of a new ARP cycle or for the negotiation of the disengagement of the researchers. The capacity to innovate of non-research actors begins strengthening during the second phase and allows actors to become progressively independent and selfreliant.

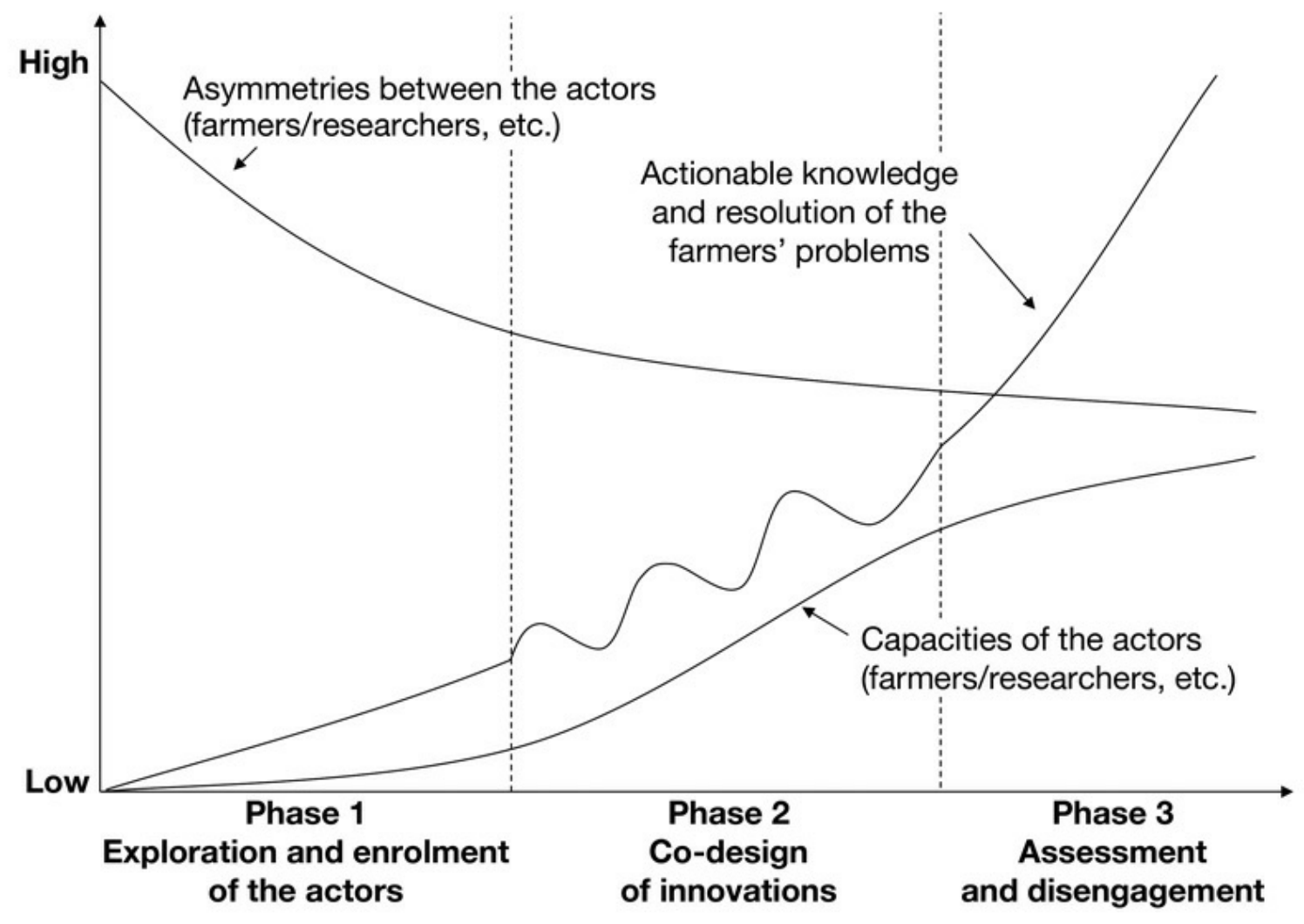


Figure 9.1. Phases and dynamics of production of the results of an action research in partnership (Vall et al., 2016).

The village consultation committee facilitates the production of a common language between the actors in the field as well as the joint formulation of development strategies. It is also a mechanism for managing relations with researchers and other stakeholders in territorial development. It is a factor of emancipation (Charbonnier, 2013).

As for the research community, this mechanism allows it to develop an ethical framework and to set up agropastoral experiments (and define their themes and choose the volunteers to manage them). It is also a place to present and discuss results and to mediate priorities.

\section{An action research in partnership built and negotiated collectively}

The researcher engaged in an action research in partnership (ARP) must learn to let his research objectives evolve and to think up new research mechanisms and forms of cooperation. The questions that he must ask himself, as stakeholder of a process of change and in relation to the other actors, can be formulated as follows:

- How to conduct research that addresses the actors' issues and how to develop a commitment to action?

- How to actively involve farmers and the other participants in the ARP, in the definition of problems, the design of the ARP mechanism, the implementation and co-management of activities, the comparison and correlation of different sources and types of knowledge, the analysis of results, and finding ways of appropriating and deriving benefits from them.

\section{Participation cannot be imposed!}

Actors do not step forward themselves to take part in an ARP. Instead their participation results from an effort of awareness-raising and construction 
between the researchers and the other actors. One of the objectives of the ARP process is to build relationships of reciprocity and equality between actors (Coenen, 2001). This partnership is not imposed by an administrative bureaucracy just because ARP is popular and therefore mandatory (Coutellec, 2015; Dhume, 2010). Even though the researcher accompanies the actors throughout the ARP process, it seems that he or she too needs to learn to become truly functional (Dulcire, 2012). The balance of power is however not shared equally between researchers and the other actors, a situation that can lead to consequences in terms of domination, increase in inequalities, power relations, symbolic violence, which must be revealed and managed (Bourdieu, 2004). It is thus up to the researcher to develop his ability to listen, translate, and question himself. The collective dynamics rely on the building of trust between the various actors and the researchers.

\section{The need to construct a common language}

Soulard et al. (2007) note that if researchers and the other actors stick to their own respective languages, a common illusion can result and lead to a fiction and, ultimately, generate friction, undermining the cooperation necessary for the smooth conduct of the ARP. The construction of a common language (Akrich et al., 2006) is a precondition for the ARP's success. De Santos (2009) describes this stage as necessary; it creates mutual understanding of different experiences without destroying the participants' respective identities.

This common language makes it possible to agree on a representation of the existing situation, on objectives to be achieved, on actions to be carried out jointly, as well as on rules of functioning, coordination and evaluation. Researchers and non-researchers then become potentially equivalent actors (Coenen, 2003), taking decisions and modifying the situation together.

\section{Agreeing and learning to act together}

As part of the ARP mechanism, a relationship of mutual trust is gradually built up, promoting the acquisition of knowledge, know-how and inter- 
personal skills necessary for action. It is on the basis of this relationship of trust that actors can work and take decisions together (Dulcire, 2012). In some cases, partners can formalize these mutual commitments in the form of a contract, which specifies the conditions for collaboration and the functions and roles of the different stakeholders (Chia et al., 2008; Vall et al., 2016). This contract promotes the creation of synergies and pooling of resources for effective joint actions while letting the participants maintain their independence and autonomy.

An ARP encourages the actors, including researchers, to question themselves and change the ways of acting and thinking. It forces them to participate in reciprocal learning and to acquire self-confidence by co-managing activities. Participating in an ARP allows participants to train themselves by and while undertaking actions, rather than undergoing training first so that they can act later. These learnings make them more resilient in the face of uncertainties, a necessity for dealing with the future. The result is a mutual emancipation of researchers and non-researchers (Rancière, 1991).

However, the co-construction of common objectives, followed by the implementation of actions to achieve these objectives, can provoke confrontations and reveal disagreements between the actors participating in an ARP. These confrontations can then be discussed and resolved through joint reconstruction. Sometimes, however, this discord can lead to the failure of the collective process, and thus of the project being undertaken by the ARP. These potential failures can in themselves build up the actors' capacities for future collective action.

Finally, in the ARP, the transition from the ' $\mathrm{I}$ ' to the 'we' (production of a common language, co-construction of a common project, followed by its joint management) is followed by a return to the ' $\mathrm{I}$ ', as concerns the use of the common results (articles, technical practices, forms of organization, etc.), individualized derivations of value, depending on the contexts and needs of each of the actors involved.

\section{Tools and mechanisms for governance}


The actors use tools to undertake the ARP's activities: production of a language, establishment of a common project, setting of rules of functioning and coordination, planning, follow-up, and the evaluation of the actions. These tools can be of various types: data collected from plots, reports of meetings, revenue and expense statements, partnership contracts, collaborative role-plays, simulation models, maps, etc. They can be designed by the actors themselves, or originate from other experiences, and be therefore exogenous. In the latter case, the actors have to contextualize them and adapt them to their situation. These tools supplement reflection and collective action. They help develop strategies, define actions, and determine the necessary short-term course corrections. While Box 9.1 emphasized experimentation with farmers, who also constitute tools for ARP, Box 9.2 shows the importance of training tools.

The ARP is part of a mechanism that is itself managed through the use of tools, such as a management committee, a scientific committee, a working group, an action plan, a monitoring and evaluation matrix, etc. The management committees that coordinate the life of the project are responsible for external communications and mediations in case of conflict, facilitate the work of the actors and evaluate the results. Chia (2004) notes that in ARPs, as in traditional research activities, scientific committees encourage the necessary distancing of researchers and reflexive action to generate valid scientific knowledge.

These tools and mechanisms constitute what may be called the technology of the governance of ARP (Vall et al., 2016). They can be supported, as in the case of Burkina Faso (Box 9.1), by the prior co-construction of an ethical framework that specifies the rules of engagement of researchers and local stakeholders.

\section{Box 9.2. Acting together to build up the capacity to innovate of rural communities in Colombia}

To make ecosystems sustainable, the capacities of collective management and creativity of rural communities have to be strengthened. In the Colombian context of post-conflict reconstruction (peace agreements signed in 2016), different rural communities 
requested training that is more suited to their needs in order to respond to local challenges. In the framework of a dialogue of knowledge, for a peaceful coexistence of communities and a sustainable and equitable economic development, educational institutions and farmer organizations[31] have jointly set up the project 'Universitiescommunities dialogue to strengthen leadership and creativity skills towards sustainability in three different rural contexts (Afro-Colombian, Amerindian and Peasant)'.

This training was designed and implemented using an ARP approach. Its objective was to strengthen the capacities of innovation of the concerned rural communities so that they could design, implement and evaluate projects meant for their well-being, in their different territorial contexts. This ARP was structured around two major activities:

- training actors so that they can implement cultural, social and productive development projects for the well-being of their communities;

- strengthening participation within communities in order to improve their collective functioning, their autonomy and the coexistence of different groups.

Participants (60 men and women in 2015) were chosen from within their community based on their commitments, while respecting a diversity of ages, with the aim of strengthening the local capacities of communities for an effective autonomy (Sierra et al., 2010; Candelo, 2014). The topics covered are summarized in Figure 9.2.
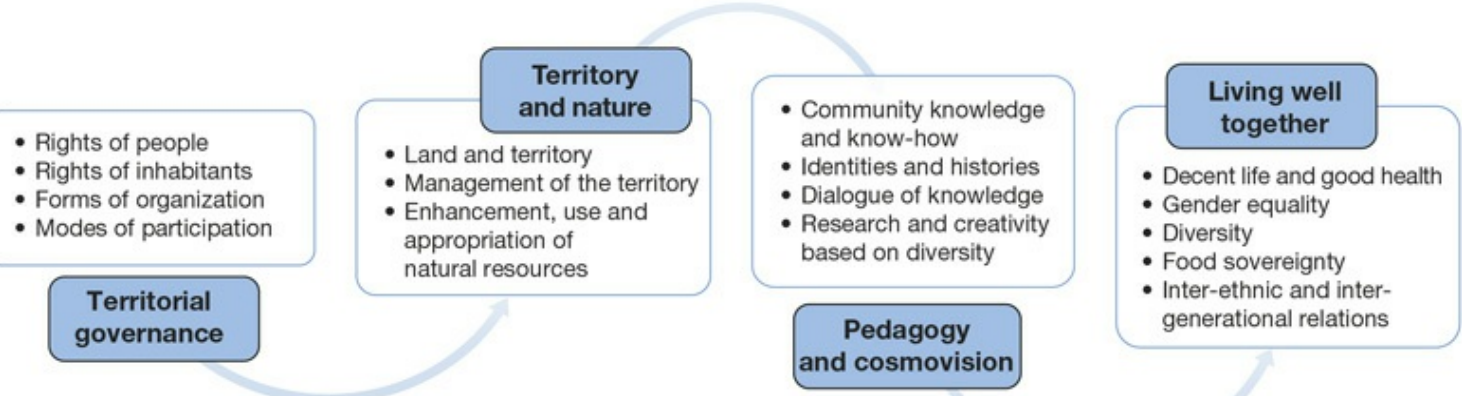

Figure 9.2. Topics of the training of rural Colombian communities. 
The training was based on Freire's (2005) principles of critical and creative pedagogy and popular education, with a view to empowering actors and co-constructing knowledge. These principles include a range of methods, such as individual presentations, debates, discussions, workshops, artistic experiences and individual and collective work. The main themes of these courses were:

- identification (how was it before, how is it now?);

- problematization (what has changed, and why?);

- the project (what should we take up or transform; what creative community projects need to be developed?);

- the implementation of these creative projects with the participants' communities.

In this framework, the participants identified, through interactions with the researchers, problems or situations requiring improvement in their community. They proposed alternatives by coming up with creative community proposals, with due acknowledgement to each participant for his or her own work. The lessons learnt during these coconstructions helped to strengthen the communities' capacities for collective work and creative innovation, and to provide elements for the creation of a continuing education program entitled 'Rurality, Equity and Diversity' to be offered in other rural areas. At the end of the ARP, a diploma was given to the participants, which served as a form of recognition.

\section{Conclusion: towards a creative partnership for supporting change}

Action research in partnership (ARP) is an approach that aims to remove the scientific domination of the researcher over the non-researcher. To do so, it mobilizes several disciplinary fields (social sciences and biotechnical sciences) and combines several types of constructivist and systemic approaches. The ARP requires the research community to adopt a specific posture in order to help participating actors build their own knowledge as part of a reflexive process and thus strengthen their individual and collective 
capacities, and no longer be mere recipients of standardised knowledge. These new capacities lead to more autonomy for participants, who can thus respond better to the challenges of sustainable development.

Thus, the ARP is above all conceived as a democratization of the scientific research approach, allowing the inclusion of actors with a wide range of cognitive abilities. It helps make the participation of these various actors more symmetrical because it can also include those who are generally excluded from political and economic decision-making. The ARP also urges other better informed actors to take into account local knowledge and methods of organization that are usually overlooked. This observation refers to the major difficulties encountered in implementing a partnership approach with different social groups, among which are often the most marginalized (Paturel, 2015).

Finally, the ARP can also inform the social criticism that shapes the different controversies on the links between science and society or between knowledge production and public action. More generally, it is part of the dynamics of debating the role of scientific expertise and the desired evolution towards good territorial governance. The empowerment of the rural actors constitutes a stimulating approach to link the concept of sustainability with those of justice, social solidarity, recognition and emancipation.

\section{Bibliography}

Akrich M., Callon M., Latour B., 2006. Sociologie de la traduction : textes fondateurs. Presse des Mines, Paris.

Anadón M. (ed.), 2007. La recherche participative : multiples regards. Presses de 1'Université du Québec, Quebec.

Boltanski L., 2011. On Critique - A Sociology of Emancipation. Polity Press, Cambridge (UK) .

Bosc P.-M., Piraux M., Dulcire M., 2015. Contributing to Innovation, Policies and Local Democracy Through Collective Action. In: Family Farming and the Worlds to Come (J.M. Sourisseau, ed.), Springer, Dordrecht, 
Bourdieu P., 2004. Science of Science and Reflexivity. Polity Press, Cambridge.

Callon M., Ferrary M., 2006. Les réseaux sociaux à l'aune de la théorie de l'acteur-réseau. Sociologies pratiques, 13(2), 37-44.

Candelo R.C., 2014. Liberando la Palabra. WWF Colombia, Cali.

Charbonnier S., 2013. À quoi reconnaît-on l'émancipation ? La familiarité contre le paternalisme. Tracés, 25(2), 83-101.

Chercheurs Ignorants (les), 2015. Les recherches-actions collaboratives, une révolution de la connaissance. EHESP, Dijon.

Chia E., 2004. Principes, méthodes de la recherche en partenariat : une proposition pour la traction animale. Revue d'élevage médecine vétérinaire des pays tropicaux, 57(3-4), 233-240.

Chia E., Dulcire M., Piraux M., 2008. Le développement d'une agriculture durable a-t-il besoin de nouveaux apprentissages ? Les leçons tirées d'une recherche en milieu insulaire. Études Caribéennes, 11,

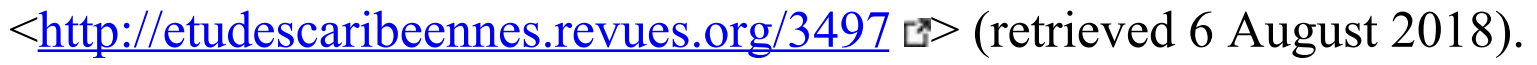

Coenen H., 2001. Recherche-action : rapports entre chercheurs et acteurs. Revue internationale de psychosociologie, 1-2(16-17), 19-32.

Coutellec L., 2015. La science au pluriel, essai d'épistémologie pour des sciences impliquées. Éditions Quæ, Versailles.

Dhume F., 2010. Du travail social au travail ensemble. Le partenariat dans le champ des politiques sociales. ASH Édition, Paris.

Dulcire M., 1996. Le jeu de l'implication et le feu de l'engagement: chroniques nicaraguayennes. Économie rurale, 236, 62-68.

Dulcire M., 2012. The organisation of farmers as an emancipatory factor: setting up of a cocoa supply chain in São Tomé. Journal of Rural \& 
Community Development, 7(2), 131-141.

Dulcire M., Chia E., Vall E., 2008. Conception des innovations et rôle du partenariat, CIROP. Bilan et perspectives. Cirad, Montpellier.

Faure G., Gasselin P., Triomphe B., Temple L., Hocdé H., 2014. Innovating with rural stakeholders in the developing world - Action research in partnership. CTA $\quad$ LM $\quad$ Lublishers, 224 p. $<$ https://publications.cta.int/media/publications/downloads/1783_PDF.pdf $4>$ (retrieved 13 July 2018).

Foucault M., 1994. The Confession of the Flesh. In: Power/Knowledge Selected Interviews and Other Writings, New York: Pantheon Books, 194228.

Freire P., 2005. Extension or Communication. In: "Freire: Education for Critical Consciousness", pp 85-99, Continuum, London-New York.

Guespin-Michel J., 2015. Émancipation et pensée du complexe. Édition du Croquant, Paris.

Lewin K., 1948. Action research and minority problems. Resolving social conflicts. Journal of social issues, 2, 34-46.

Paturel D., 2010. La fonction de Tiers Social. L'Harmattan, Paris.

Paturel D., 2015. La recherche participative en travail social : l'option d'une épistémologie et d'une méthodologie constructiviste. In: Les recherchesactions collaboratives, une révolution de la connaissance (Les chercheurs ignorants, eds), EHESP, Dijon, 197-205.

Rancière J., 1991. The Ignorant Schoolmaster. Five Lessons in Intellectual Emancipation. Stanford University Press, Stanford.

Richez-Battesti N., Petrella F., Vallade D., 2012. L'innovation sociale, une notion aux usages pluriels : quels enjeux et défis pour l'analyse ? Innovations, 38(2), 15-36.

Santos (de) B., 2009. Una Epistemología del Sur. La reinvención del 
Conocimiento y la Emancipación Social. Siglo xxi, Buenos Aires.

Sen A., 2009. The idea of justice. Belknap Press of Harvard University Press, Cambridge, Mass.

Sierra Z., Siniguí S., Henao A., 2010. Acortando la distancia entre la escuela y la comunidad: Experiencia de construcción de un currículo intercultural en la Institución Educativa Karmata Rúa del Resguardo Indígena de Cristianía, Colombia. Visão Global, 13(1), 219-252.

Soulard C.-T., Compagnone C., Lémery B., 2007. La recherche en partenariat, entre fiction et friction. Natures, Sciences, Sociétés, 15(1), 13-22.

Storup B., 2013. La recherche participative comme mode de production de savoirs. Fondation Sciences Citoyennes, Paris.

Vall E., Chia E., Blanchard M., Koutou M., Coulibaly K., Andrieu N., 2016. La co-conception en partenariat de systèmes agricoles innovants. Cahiers Agricultures, 25(1), 15001.

\section{Chapter 10}

\section{Co-designing technical and organizational changes in agricultural systems}

Nadine Andrieu, Jean-Marc Barbier, Sylvestre Delmotte, Patrick Dugué, Laure Hossard, Pierre-Yves Le Gal, Isabelle Michel, Fabien Stark and Stéphane DE TOURDONNET

Summary. The transformations currently underway in agriculture are throwing the 
spotlight on the studies and methods currently used to design innovative farming systems. This chapter analyses the specificity of five approaches for co-designing technical systems that have been tested in France and in some African and Latin American countries. They are based on a high level of interaction between actors involved in these approaches, and are facilitated by a range of intermediary objects such as modelling tools and agricultural experimentation in a rural environment. They have led to the production of operational and scientific knowledge on technical changes and the conditions under which they can be implemented at the farm level, as well as the institutional conditions conducive to the emergence of new systems. These approaches rely on skills that go beyond those pertaining to agronomy alone; the inclusion of social science researchers may become necessary, in particular to analyse how to hybridize various types of knowledge in order to accompany innovation on farms and in territories.

Agriculture is addressing new challenges. It needs to become more efficient in order to meet increasingly important societal expectations, such as the reduction in pollution caused by the use of fertilizers and pesticides, a reduction in energy consumption and greenhouse gas emissions, the maintenance of biodiversity and access to a healthy and balanced diet (Schaible and Aillery, 2017; Brooks, 2014).

These challenges require agricultural innovation to be supported in its technical, organizational and institutional dimensions (Chapter 3). The farmer plays an active part in this process. He can no longer be relegated to the role of an end user, adopting technical proposals originating from the research community, but instead becomes a co-designer of innovation (Chapter 8). Such a shift requires an in-depth review of the studies and methods used to design innovative farming systems (Meynard et al., 2012).

These studies focus on the development of methods for the design and assessment of farming systems at several levels (Meynard et al., 2012), from the plot or the herd to the farm or the territory. Agronomists analyse, on this basis, the short- and long-term effects of innovations (varieties, pesticides, fertilizers, biotechnologies, and cropping, livestock and irrigation methods) by taking into account the changes they are likely to induce on production systems, territories and value chains. This knowledge is used to design new cropping and livestock systems, combining scientific knowledge with the empirical knowledge of the actors directly involved.

Design processes are by nature diverse. Hatchuel et al. (2006) differentiate 
two main types. In the first, the design process is systematic, with the knowledge and expertise required available at the beginning of the process. The design goals and validation processes (prototypes, trials, tests, division of tasks) are clearly defined in advance. In the second, the innovative design aims to meet new expectations that were not explicitly defined at the outset. Through a process of dialogue, actors decide on multiple goals as the design process unfolds. As an extension of this distinction, Meynard et al. (2012) specify a de novo design and a step-by-step design in agriculture. The de novo design is oriented towards the invention of systems (crops, livestock husbandry, production) that represent a break from existing systems. It is accompanied by the drawing up of scenarios, which allow the exploration of a wide range of possible future situations involving profound changes. But this approach does not focus on the transformations needed to move from the current system to the innovative system (Prost et al., 2016). In contrast, the step-by-step design seeks to recommend and implement changes or evolutions based on iterative assessments and learning loops. In this incremental approach, the farmer gradually develops his new system, all the while learning to manage it, even as he convinces himself of its benefits and reorganizes his work and his means of production accordingly.

Basing themselves on a review of the literature, Le Gal et al. (2011) fine-tune the reflection with a typology of design approaches. They highlight 'designoriented' approaches, in which the actors' participation is limited, and 'design-support' approaches, in which the focus is on supporting the actors in a process of technical and/or organizational changes. The first type includes prototyping and modelling approaches. The second includes 'participationbased' approaches aimed at building up the capacities of actors without recourse to modelling; 'support-modelling' approaches based on the use of modelling tools and actor participation to compare different technical alternatives; and, finally, 'advisory-oriented' approaches to provide advice to farmers. These participatory processes are especially important for creating new knowledge, learnings, technologies and products that are useful for farmers (Berthet et al., 2015). Indeed, in these processes the management of the interactions between stakeholders of the action-research process is key to better combine or hybridize multiple forms of knowledge. They use specific exploration tools to do so, which facilitate mediation and the development of a common language among partners. These tools thus play the role of 
intermediary objects (Vinck, 1999).

The goal of this chapter is to analyse the specificity of the approaches for the co-design of technical systems used by its various authors, by positioning them and comparing them to others referenced in the literature. To this end, we present five case studies of approaches that aim to build methods, tools and mechanisms for the co-design and participatory assessment of technical systems in varied contexts.

The technical system corresponds to all the technical means and management practices of crop or livestock systems used by a farmer at the farm level to obtain results by mobilizing factors of production and decision-making rules (Osty, 1996). This concept allows the consideration of a broad range of studies, such as the assessment of the performance of production units and the farm, the analysis and support of the farmers' decision-making processes or the way in which they allocate their resources for agricultural and livestock production.

The common feature of the five case studies analysed is the relationship between the farmer and the technique, which incorporates the diversity of types of agriculture (organic farming, agroforestry, conservation agriculture, mixed farming systems), in the countries of both the Global North and the Global South, in order to support the innovation processes that take place at the farm or territorial level (agrifood supply basin, spaces shared by various actors).

As suggested by Berthet et al. (2015), we analyse the approaches implemented for the co-design of technical systems according to three dimensions: the type of interactions between actors, the type of intermediary objects mobilized with the actors, and the results obtained by these approaches. We also position these co-design approaches with respect to the starting point chosen by the designers to support the evolution of the practices, as defined by Doré and Meynard (2006), namely the knowledge on the biophysical functioning of the productions concerned, the technique, and the rationale behind the action. 


\section{Whe types of interaction between actors in the co-design of technical systems}

The five approaches analysed (Table 10.1) are based on interactions between researchers and farmers. Some also include actors of advisory services, or even institutional actors.

Table 10.1. Characteristics of the five approaches studied for co-designing technical systems.

\begin{tabular}{|c|c|c|c|c|}
\hline Case study & Objective & Study area & \begin{tabular}{|l} 
Actors \\
involved
\end{tabular} & Source \\
\hline $\begin{array}{l}\text { Improvement } \\
\text { of cotton- } \\
\text { cereal- } \\
\text { livestock } \\
\text { systems } \\
\text { (French } \\
\text { abbreviation: } \\
\text { ACCE) }\end{array}$ & $\begin{array}{l}\text { Improve cotton-cereal- livestock } \\
\text { systems in the context of growing } \\
\text { human pressure and degradation } \\
\text { of natural resources }\end{array}$ & $\begin{array}{l}\text { North } \\
\text { Region of } \\
\text { Cameroon }\end{array}$ & $\begin{array}{l}\text { Farmers and } \\
\text { advisers of } \\
\text { the Cameroon } \\
\text { Cotton } \\
\text { Development } \\
\text { Corporation }\end{array}$ & $\begin{array}{l}\text { Djamen } \\
\text { Nana et } \\
\text { al. } \\
(2003) ; \\
\text { Dugué } \\
\text { and } \\
\text { Dounias } \\
(1997)\end{array}$ \\
\hline $\begin{array}{l}\text { The } \\
\text { Integrated } \\
\text { Assessment } \\
\text { of } \\
\text { Agricultural } \\
\text { Systems } \\
\text { approach } \\
\text { (IAAS) }\end{array}$ & $\begin{array}{l}\text { Ex-ante definition and } \\
\text { assessment of future agricultural } \\
\text { scenarios, involving the rice } \\
\text { farmers' organization and the } \\
\text { Camargue Regional Nature Park, } \\
\text { especially for the extension of the } \\
\text { conversion to organic farming }\end{array}$ & Camargue & $\begin{array}{l}\text { Rice farmers' } \\
\text { organization, } \\
\text { Camargue } \\
\text { Regional } \\
\text { Nature Park }\end{array}$ & $\begin{array}{l}\text { Delmotte } \\
\text { et al. } \\
(2016)\end{array}$ \\
\hline $\begin{array}{l}\text { Agroecology- } \\
\text { Based } \\
\text { Aggradation- } \\
\text { COnservation } \\
\text { agriculture } \\
\text { (ABACO) }\end{array}$ & $\begin{array}{l}\text { Conduct tests with actors in the } \\
\text { field on the technical and } \\
\text { organizational feasibility of } \\
\text { conservation agriculture in sub- } \\
\text { Saharan Africa }\end{array}$ & $\begin{array}{l}\text { Burkina } \\
\text { Faso }\end{array}$ & $\begin{array}{l}\text { Farmer } \\
\text { organizations, } \\
\text { advisers, } \\
\text { traditional } \\
\text { authorities, } \\
\text { technical } \\
\text { services }\end{array}$ & $\begin{array}{l}\text { Dabire et } \\
\text { al. } \\
(2016)\end{array}$ \\
\hline $\begin{array}{l}\text { The Crop } \\
\text { LIvestock } \\
\text { Farm }\end{array}$ & & $\begin{array}{l}\text { Brazil, } \\
\text { Morocco, } \\
\text { Peru, } \\
\text { Madagascar, } \\
\text { south- }\end{array}$ & Farmers, & $\begin{array}{l}\text { Le Gal et } \\
\text { al. }\end{array}$ \\
\hline
\end{tabular}




\begin{tabular}{|l|l|l|l|l|}
$\begin{array}{l}\text { Simulator } \\
\text { approach } \\
\text { (CLIFS) }\end{array}$ & $\begin{array}{l}\text { Help farmers who are } \\
\text { undertaking a medium- or long- } \\
\text { term evolution of their farms in } \\
\text { their reflections on possible } \\
\text { avenues to use co-constructed } \\
\text { scenarios }\end{array}$ & $\begin{array}{l}\text { France, } \\
\text { Burkina } \\
\text { Faso }\end{array}$ & advisers & (2013) \\
\cline { 2 - 5 } $\begin{array}{l}\text { Decision- } \\
\text { making } \\
\text { support } \\
\text { implemented } \\
\text { by students of } \\
\begin{array}{l}\text { Montpellier } \\
\text { SupAgro } \\
\text { (SupAgro) }\end{array}\end{array}$ & & Camargue & $\begin{array}{l}\text { Students, } \\
\text { educational } \\
\text { team, farmers }\end{array}$ & $\begin{array}{l}\text { Michel et } \\
\text { al. } \\
\text { (2018) }\end{array}$ \\
\hline
\end{tabular}

The ACCE (Improvement of cereal-cotton-livestock systems) and CLIFS (Crop Livestock Farm Simulator) approaches additionally target the adviser, which has repercussions on the person in charge of using the co-design tools, and on their transfer to actors in the field. The ACCE approach is based on steps that rely on the adviser's expertise, especially during farm experiments, to develop and validate technical innovations with farmers and to monitor, over an annual cycle, the resulting changes in the management of certain production units and resources. As for the CLIFS approach, it is implemented by the farmer with the support of an interlocutor who could be an adviser. The CLIFS approach simulates and assesses an initial scenario, followed by scenarios of strategic change desired by the farmer based on his production goals and the performance of the simulated scenarios.

In the IAAS (Integrated Assessment of Agricultural Systems in Camargue) and ABACO (Agroecology Based Aggradation Conservation Agriculture) approaches, several actors of the farmers' institutional environment are involved. The IAAS approach involves farmers and local institutions dealing with agricultural issues. The commitment of these actors to the project is formalized, and their perceptions of changes in and the future of agriculture in the territory are taken into account, as are their criteria for appreciation and performance. They are then involved in the subsequent steps of the process, i.e. simulation and discussion of change scenarios at different scales (plot, farm, the Camargue region). In the case of the ABACO approach, an innovation platform composed of two bodies is formalized: 
- a technical body, composed of representatives of cotton farmer organizations and livestock farmer organizations, and technical services, which is responsible for co-designing cropping systems based on the principles of conservation agriculture;

- an institutional body, made up of traditional authorities, of cotton farmer organizations and livestock farmer organizations, and technical services, which is responsible for dealing with issues of access to markets, to crop residues and to land.

The interaction between researchers and actors in the field is crucial in all these approaches, both to produce knowledge on the technical systems being implemented and to co-construct alternatives. This partnership is often informal in nature. Nevertheless, Vall et al. (2016) show the importance of formalizing it by creating a goal that is shared between the partners and by defining a set of specifications to adhere to. Such an effort is conducive to effective changes, since they are the result of the commitment of the actors.

\section{Whe types of intermediary objects in the co- design of technical systems}

In all these five approaches, we observe the important role of intermediary objects based mainly on the use of modelling tools or experimentation.

This important role of modelling tools is observed in other studies in the literature on co-design (Duru et al., 2012; Moraine et al., 2016; Stark and Fanchone, 2014). It allows the revitalization of an agronomy of practices sometimes considered too descriptive and limited to an ex post assessment by more prospective approaches. Modelling tools can be used at different codesign stages to represent the objects under study, simulate their evolution or assess them ex ante.

The use of experimentation as an intermediary object in co-designing is also very common in studies on the prototyping of cropping systems (Rapidel et al., 2009; Le Bellec et al., 2012). It allows the farmer to assess the feasibility of the technical changes on his own, with some help from the researcher. 
In three of the five approaches studied, modelling tools take different forms. These include using spreadsheets, bio-economic or multi-agent models, as well as cartographic representations. The aim of these tools is to both summarize and link the knowledge on existing technical systems and, most importantly, to explore changes with actors.

Thus, the CLIFS approach is based on the use of a simulation tool dedicated to mixed crop-livestock farms, which can be understood by farmers and advisers, both in its structure and in its calculation procedures and output variables. The calculation tool can be used by the farmers and can be transferred to agricultural advisers. This simulation tool serves as a basis for dialogue between the researcher and the farmer -and the adviser, should one be involved - concerning strategic changes on the farm.

In the approach used by the students of Montpellier-SupAgro, they made a conceptual model of the crop planning and rotation rules, the organization of the work over the year, and management of the cropping systems. They then designed very simple computer models: cartographic representations of the plots using geographical information systems and spreadsheets with the rules for organizing the work. These tools allow students to test the changes a farmer would like to introduce, while representing the possible steps for their implementation on the farm (for example, introduction of a new crop or conversion to organic farming). The results of the simulations are discussed by the students and with the farmer, and studied with regard to the impacts and the feasibility of these changes on his farm.

The IAAS approach also uses modelling tools as a basis for discussion with actors in different arenas (participatory workshops, more formal meetings with institutional actors), but uses three different types of tools: crop models, to describe the performances of conventional and organic cropping systems; a multi-agent model, used during collective sessions with farmers to identify possible technical paths of evolution towards organic farming; and a bioeconomic model, for a multi-criteria assessment with local actors of different options for the extension of organic farming at the farm and regional scales.

In the ACCE approach, experimentation, followed by the presentation and discussion of results, was the main intermediary object. The shared diagnosis made by researchers and farmers of farm operations and the sharing of rules 
of calculation to better assess fodder stocks are also intermediary objects that help promote discussion on technical and organizational changes on farms.

As part of the ABACO approach, several intermediary objects have been proposed to facilitate innovation platforms:

- individual experimentation by the farmer with cropping systems based on the principles of conservation agriculture, so that he can assess their feasibility;

- computer simulation of farm performances, with a limited number of farmers, to discuss the possible links between cropping and livestock systems;

- territory-scale maps, to discuss with the farmers the creation of village zones dedicated to conservation agriculture.

\section{The results of these approaches for co-designing technical systems}

These different co-designing approaches analysed have led to different kinds of results.

\section{Design of tools and methods appreciated by farmers}

In general, the farmers appreciated the capacity of the tools and methods used for incorporating the different components of the farm in a holistic approach, and for comparing different options and their effects on the management of production factors and on performance. This was especially the case for the CLIFS, IAAS and Montpellier-SupAgro approaches. The quantitative assessment of possible future changes, which were carried out for their own farms and not for hypothetical cases, and the realistic nature of the simulated scenarios were also appreciated.

The different approaches also led to the design of methodological tools that can be useful in other situations. The CLIFS software can be used not only for other farms in the same area, but also in other countries, albeit with some 
adaptations. The IAAS approach has resulted in a generic method of integrated assessment of production systems that can be used to analyse a variety of indicators at different scales (farm and territory).

\section{Operational and scientific knowledge of technical changes and the conditions necessary for their implementation at the farm level}

These approaches make it possible for researchers and farmers to coconstruct shared visions and to explore possible futures, as observed in other similar studies (Martin et al., 2011; Moraine et al., 2016). They have thus made it possible to explore along with farmers paths to technical improvement such as conservation agriculture, insertion of fodder crops into rotations, more intensive husbandry of certain draft and livestock animals, production of organic manure, and changes in rotation or crops.

The conditions necessary for implementing these technical changes on the farm could also be apprehended, mainly with regard to labour requirements, cash and income management, and/or crop rotation choices. The CLIFS and SupAgro approaches have more specifically made it possible to discuss with the farmers the strategic orientations possible in terms of production units and also to determine the size of these units (the size of a dairy herd and the crop rotation to be adopted, for example). This enhanced knowledge of the actors is an important prerequisite to changes in practices and transformations of cropping and livestock systems.

Using a co-design approach to market gardening systems, Dogliotti et al. (2014) were able to analyse the effects on the practices of the farmers participating in the experiment. Observing changes in practices is much more difficult when the approaches are aimed at orienting the farmers' strategic choices, but this analysis of the approaches' effects remains useful for improving our ways of interacting with the actors. This type of analysis was undertaken as part of the ABACO approach, which led to an improvement in the farmers' knowledge of conservation agriculture and to the beginning of the adoption of these innovative systems. Similarly, Sempore et al. (2016), having implemented an approach of individual support similar to that of 
CLIFS, have shown its positive effect on practices, the result of an improved knowledge of the flows between cropping systems and livestock systems.

It therefore seems important to improve the assessment of these approaches' effects, which may take the form of a stimulation of learning, tangible decisions taken by farmers, or the adoption of new co-designed technical systems and their impact on food security or incomes.

\section{Scientific knowledge on the institutional conditions conducive to the emergence of new systems}

These approaches also helped identify institutional conditions that are conducive to the emergence of new production systems. While these conditions were sometimes taken into account in the methods and models used, in other cases, they were only revealed during the discussions with the actors involved. They include, for example, the need for collective action or shared equipment, the importance of the supply of inputs and seeds, and enhanced land tenure security (ownership, rental, sharecropping), topics that were addressed at the end of the discussions within the framework of the ACCE approach. In the IAAS approach, the consequences of a change in public agriculture support policies (reduction of direct aid to farmers for cultivation, strengthening of agri-environmental measures) on crop rotations on farms and on the use of the territory's agricultural area, as also the consequences of changes in land use on environmental, economic and social indicators, were more explicitly incorporated into the modelling tools. The limitations of a more widespread adoption of organic farming in the territory were discussed, as were the complementarities between different forms of agriculture being practised in the same space.

Some of these studies led to recommendations addressed to development actors for facilitating changes on a larger scale. In the North Region of Cameroon, the ACCE approach has led to the setting up of regional development programmes and new rules for the management of space at the village level and for the functioning of farmer groups for managing the stock of an input required for livestock husbandry (veterinary medicines). The 
IAAS approach and some of its results were used by representatives of the Camargue Regional Nature Park to help draft local agri-environmental measures. The ABACO approach has also made it possible to define new rules for access to crop residues at the collective (village) level and to start deliberations on land charters.

\section{W Conclusion and perspectives for the evolution of approaches for co-designing technical systems}

The approaches for co-designing technical systems presented in this chapter bolster the managerial capacities of farmers so that they can develop solutions on their own to address the issues they and their families face. To this end, they use various intermediary objects, facilitating the development of a common language between the partners in the approach and the exploration of possible futures. The innovations co-designed in these approaches concern technical objects (the soil management), a complete system (a cropping or production system, for example, for multicroplivestock farms) or an organizational change (management of labour and equipment), which are resituated within the farm and the territory.

Current transformations in agriculture, especially those based on agroecology, have thrown the spotlight on these approaches for co-designing technical systems to support farmers. However, they also call for the strengthening of interactions between farmers and other concerned actors (mainly those belonging to food systems, when it is a matter of improving food security, or those involved in ecosystem management, when it is a matter of preserving natural resources). These interactions with multiple actors can be decisive in orienting innovations (choice of innovations, feasibility and acceptability).

The authors of these research studies all mention processes that require skills which go beyond those pertaining to agronomy alone, for example, for assessing learning or for understanding issues concerning scaling of transformations. These constraints raise the issue of the configuration of action-research mechanisms, which may require the inclusion of social science researchers. 


\section{Bibliography}

Berthet E.T.A., Barnaud C., Girard N., Labatut J., Martin G., 2015. How to foster agroecological innovations? A comparison of participatory design methods. Journal of Environmental Planning and Management, 1-22, doi:10.1080/09640568.2015.1009627 주

Brooks J., 2014. Policy coherence and food security: The effects of OECD countries' agricultural policies. Food Policy, 44, 88-94.

Dabire D., Andrieu N., Djmen P., Coulibaly K., Posthumus H., Diallo A.M., Karambiri M., Douzet J.-M., Triomphe B., 2016. Operationalizing an innovation platform approach for community-based participatory research on conservation agriculture in Burkina Faso. Experimental agriculture, 53(3), 460-479.

Delmotte S., Barbier J.-M., Mouret J.-C., Le Page C., Wery J., Chauvelon P., Sandoz A., Lopez Ridaura S., 2016. Participatory integrated assessment of scenarios for organic farming at different scales in Camargue, France. Agricultural systems, 143, 147-158.

Djamen Nana P., Djonnewa A., Havard M., Legile A., 2003. Former et conseiller les agriculteurs du Nord-Cameroun pour renforcer leurs capacités de prise de décision. Cahiers Agricultures, 12, 241-245.

Dogliotti S. García M.C., Peluffo S., Dieste J.P., Pedemonte A.J., Bacigalupe G.F., Scarlato M., Alliaume F., Alvarez J., Chiappe M., Rossing W.A.H., 2014. Co-innovation of family farm systems: A systems approach to sustainable agriculture. Agricultural Systems, 126, 76-86.

Doré T., Meynard J.-M., 2006. Trois approches agronomiques pour appuyer l'évolution des pratiques agricoles, In: L'agronomie aujourd'hui (Doré T., Le Bail M., Martin P., Ney B., Roger-Estrade J, eds), éditions Quæ, Versailles, 33-41.

Dugué P., Dounias I., 1997. Intensification, choix techniques et stratégies paysannes en zone cotonnière du Cameroun. Le cas des systèmes de culture des zones d'installation des agriculteurs migrants, In: Succès et limites des 
révolutions vertes (Griffon M., ed.), Cirad, Montpellier, France, 93-106.

Duru M., Felten, B., Theau J.-P., Martin G., 2012. A modelling and participatory approach for enhancing learning about adaptation of grasslandbased livestock systems to climate change. Regional Environmental Change, $12,739-750$.

Hatchuel A., Le Masson P., Weil B., 2006. Les processus d'innovation. Conception innovante et croissance des entreprises. Hermès, Paris.

Le Bellec F., Rajaud A., Ozier-Lafontaine H., Bockstaller C., Malezieux E., 2012. Evidence for farmers' active involvement in co-designing citrus cropping systems using an improved participatory method. Agronomy for Sustainable Development, 32(3), 703-714.

Le Gal P.-Y., Bernard J., Moulin C.-H., 2013. Supporting strategic thinking of smallholder dairy farmers using a whole farm simulation tool. Tropical Animal Health and Production, 45, 1119-1129.

Le Gal P.-Y., Dugué P., Faure G., Novak S., 2011. How does research address the design of innovative agricultural production systems at the farm level? A review. Agricultural Systems, 104, 714-728.

Martin G., Theau J.-P., Therond O., Martin-Clouaire R., Duru M., 2011. Diagnosis and simulation: a suitable combination to support farming systems design. Crop \& Pasture Science, 62, 328-336.

Meynard J.-M., Dedieu B., Bos A.-P., 2012. Re-design and co-design of farming systems. An overview of methods and practices. In: Farming Systems Research into the 21st century: The new dynamic (I. Darnhofer, D. Gibbon, B. Dedieu, eds), Springer, 407-432.

Michel I., Barbier J.M., Mouret J.-C., 2018. La Camargue rizicole : un laboratoire à ciel ouvert pour former des ingénieurs agronomes, In: Le Riz et la Camargue. Vers des agroécosystèmes durables (Mouret J.-C., Leclerc B., coord.), Cardère - Éducagri, 71-81.

Moraine M., Grimaldi J., Murgue, C., Duru M., Therond O., 2016. Co-design 
and assessment of cropping systems for developing crop-livestock integration at the territory level. Agricultural Systems, 147, 87-97.

Osty P.L., 1996. Methods and scales of intervention. What methodological renewal for system research? In: System-oriented research in agriculture and rural development. Proceedings of an international symposium, November 21-25 1994, Montpellier, France, Cirad, 196-210.

Prost L., Berthet E.T.A., Cerf M., Jeuffroy M.-H., Labatut J., Meynard J-M., 2016. Innovative design for agriculture in the move towards sustainability: scientific challenges. Research in Engineering Design, Springer Verlag, doi:10.1007/s00163-016-0233-4 “.

Rapidel B., Traore B.S., Sissoko F., Lancon J., Wery, J., 2009. Experimentbased prototyping to design and assess cotton management systems in West Africa. Agronomy for Sustainable Development, 29, 545-556.

Schaible G.D., Aillery M.P., 2017. Challenges for US Irrigated Agriculture in the Face of Emerging Demands and Climate Change. In: Competition for Water Resources. Experiences and Management Approaches in the US and Europe (J.R. Ziolkowska, J.M. Peterson, eds), Elsevier, 44-79.

Sempore A.W., Andrieu N., Nacro H.B., Le Gal P.-Y., Sedogo M.P., 2016. Supporting better crop-livestock integration on small-scale West African farms: a simulation-based approach. Agroecology and sustainable food systems, 40, 3-23.

Stark F., Fanchone A., 2014. Le concept d'intégration au cœur de la conception d'un pilote en polyculture-élevage adapté aux exploitations agricoles de Guadeloupe. Innovations Agronomiques, 39, 113-124.

Vall E., Chia E., Blanchard M., Koutou M., Coulibaly K., Andrieu N., 2016. La co-conception en partenariat de systèmes agricoles innovants. Cahiers Agricultures, 25(1).

Vinck D., 1999. Les objets intermédiaires dans les réseaux de coopération scientifique. Contribution à la prise en compte des objets dans les dynamiques sociales. Revue française de sociologie, 40, 385-414. 


\title{
Chapter 11
}

\section{Advice to farms to facilitate innovation: between supervision and support}

\author{
Guy Faure, Aurélie Toillier, Michel Havard, Pierre \\ Rebuffel, Ismaïl M. Moumouni, Pierre Gasselin and \\ HÉLÈNE TALLON
}

Summary. Agricultural advisory services are important to improve farm performances and the farmers' ability to innovate. However, their effectiveness is regularly called into question. In this chapter, we discuss the evolution of agricultural advisory services and show how the mechanisms and methods used to provide advice have changed over time. There exist several different approaches to providing advice, based on different principles, which include decision support, problem resolution, capacity building for farmer empowerment, and support for individual or collective projects. The choice of an approach depends not only on the nature of the problem to be addressed and the solutions to be implemented, but also on the capacities of the advisers, the objectives set by advisory organizations, and the mechanisms for the governance and funding of agricultural advisory services.

Agricultural advisory services are perceived by agricultural development actors as an important contributor to the improvement of farm performances. Nevertheless, they are regularly called into question regarding their ability not only to meet the diverse - and sometimes contradictory - expectations of producers and of the other actors of agricultural sectors and territories, but also to facilitate innovation.

Agricultural advice comes in many forms as regards its content, the manner of providing it, and the nature of the organizations that provide it. As a result, there exist multiple definitions of agricultural advice (Faure et al., 2012). In the meaning we give to it, agricultural advice encompasses, on the one hand, the actors involved, the advisory activity, the physical resources used, the rules defined to achieve the objectives that the actors have set themselves, and, on the other hand, the knowledge, know-how and methods used by the 
advisory actors, in particular by the advisers, to create knowledge useful for action, in individual or collective learning situations. The farmer can access different types of advice, defined by its content (technical, economic, social, environmental, etc.) or by the way it is provided (dissemination of information and techniques, reinforcement of learning, support of initiatives, facilitation of interactions between actors, etc.). Given this very inclusive definition of the term 'advice', it can be provided in many different ways, the most emblematic ways being (i) the dissemination of generic and normative messages originating from the knowledge produced by the research community, (ii) the co-construction by the recipient and the provider of the advice to address a specific problem, and (iii) the accompaniment and support of farmers to help them formulate and carry out their projects.

In this chapter, we will discuss the evolution of agricultural advisory services to show how the mechanisms and methods to provide advice have evolved over time. We will then analyse how advice enables and facilitates innovation at the farm level. We will show that this support relies on different advisory approaches that are based on different principles, but which often have to be combined. We will then analyse two examples of advisory mechanisms to draw lessons on how to provide support for innovation.

\section{Evolution of agricultural advice over time}

The history of agricultural advisory services has been marked by several developments. Around the world, massive public investments in agricultural advisory services were made after the Second World War in order to modernize agriculture and promote agricultural innovations. This approach started being called into question beginning in the 1990s, especially in the countries of the Global South, in the context of structural adjustment policies that were leading to the withdrawal of States from a service that was often considered expensive and ineffective. With funding originating from new orientations in development aid and from the private sector, new actors, such as producer organizations, non-governmental organizations, and upstream and downstream companies, have emerged in the world of agricultural advisory services. However, the process has not been of a uniform nature or experienced the same intensity across the world, leading to very varied 
country- or region-specific advisory landscapes: still diversified in Europe, heavily marked by the presence of private operators in Latin America, weakened and still undergoing reconfiguration in Africa. The orientation of agricultural advisory services, and therefore of the innovation processes that they support, depends largely on the major actors providing the advice. Agricultural advice can be oriented by producers on the basis of their needs and demands. It can also be driven by the market and by the requirements of companies located upstream or downstream of farms, or defined by public actors to ensure a minimal level of agricultural training for farmers or to take collective interests into account.

The advisory approaches therefore have had to adapt to the changing context. During the period of strong State interventionism, the advisory services were instrumental in increasing production by favouring, in a top-down logic, the transfer of knowledge and techniques to the farmers. Innovation was then seen as originating with public or private research entities, and agricultural advisory services were the means to disseminate technical messages from scientific research and the development apparatus. The intervention model known as the 'training and visit' system, promoted by the World Bank until the 2000s, was emblematic of such a vision. Given the limitations of these approaches (lack of effectiveness in areas with low agricultural potential; difficulty in addressing complex problems, such as natural resource management or farm management; negative effects in some areas following the excessive use of chemical inputs), new approaches to agricultural advisory services were tried out. They focused on participatory methods in order to better take the farmer's needs and his room for manoeuvre into account. Farmers then began to be seen as actors of innovation. These methods have been widely deployed since the 1980s, and include, for example, 'farming systems' approaches (Chambers et al., 1989) and research and development approaches (Jouve and Mercoiret, 1987), focusing on understanding farmer rationales and on adapting technologies to local conditions. In the 1990s, in the countries of the Global South, methods for 'participatory technology development' and 'participatory learning and action research' highlighted the process of learning and of using and taking advantage of the farmers' knowledge (Röling and Jong, 1998). The 'farmschool' approach, still promoted by the Food and Agriculture Organization of the United Nations, is also emblematic of such a vision. These approaches 
can be clubbed with older experiments, conducted in particular in France within the framework of Ceta (Agricultural Technology Experimentation Centres), which brought farmers together so that they could share their experiences regarding production and farm management with the help of advisers. During the same period of the 1990s, support was also provided to experimenter-farmer networks in Latin America (Hocdé and Miranda, 2000), which took advantage of the farmers' knowledge and its mode of dissemination from farmer to farmer (de campesino a campesino).

Some experiments in providing agricultural advice, carried out by nongovernmental organizations or by some research entities, stress the need for approaches that provide comprehensive farm-level advice incorporating the technical and economic dimensions. These experiments are based on an individual and collective learning approach. In France, Rural Economy Centres, Chambers of Agriculture and associations such as AFOCG (Farmers' Association for Management and Accounting) also use these comprehensive approaches at the farm level to strengthen farmers' management capacities. In Africa, the first experiments, called 'management advice' or 'management advice for family farms', date back to the 1990s. They use decision support tools, some of which can be used by illiterate farmers since they require no reading or writing (Faure and Kleene, 2004; Dorward et al., 2007). By relying on action-training approaches cognizant of the reality of farms and by encouraging individual reflection and exchanges between producers, these experiments make it possible to strengthen the decision-making capacities of farmers, and thus their autonomy. In this sense, they strengthen the farmers' capacities to innovate.

The increasing diversity of methods now available to go beyond the simple transfer of knowledge and techniques is the result of changes in thinking regarding the provision of agricultural advice and the objectives for providing support to rural actors. These objectives now aim at promoting the dynamics of innovation, reinforcing learning processes, building up capacities for action and adaptation and, ultimately, increasing the producers' autonomy.

\section{Whe role of agricultural advisory services in supporting innovation on farms}




\section{Characteristics of innovation at the farm scale}

At this stage of our reflection, it is necessary to characterize innovation at the micro-economic scale of the farm. Schumpeter (1934) placed the entrepreneur at the centre of the innovation process. This process is defined as a new combination of factors of production, which manifest in the creation of a new product, in a new way of producing, in the construction of new markets, or in access to new resources. This definition shows that innovation has many facets. More generally, innovation encompasses various dimensions: technical, economic, social, or organizational. Indeed, as Leeuwis and Aarts (2011) note, innovation always results from the synergy between several dimensions. These authors believe that an innovation combines the implementation of new techniques and practices (what can be referred to as hardware), new knowledge and modes of thinking (software) and new institutions and organizations (orgware). Innovation can be simple or complex, incremental or radical. In a perspective in which innovation is centred on the individual, innovation is the result of the efforts of the entrepreneur who decides to change. In this chapter, we will retain such a perspective, even though it partially ignores the entrepreneur's relationships with other actors (suppliers of goods and services, for example) who also structure the innovation process. Other chapters in this book show how innovation arises from interactions between various actors who pool resources and together create actionable knowledge.

Innovations at the farm scale can concern production processes, and many actors first think about his domain when they want to promote innovation in agriculture. In such cases, innovation may concern a part of the production system, by introducing a new technology (for example, a new crop variety or a new tillage tool). Innovation of this type is considered incremental since it does not entail a drastic change in the functioning of the farm. Innovation may also involve the entire production system (for example, a transition to conservation agriculture or organic farming, or the introduction of mechanization). It is then radical in nature because the overall functioning of the farm has to be revamped. However, improving access to means of production (land, water, labour, credit, inputs, etc.) or improving the management of post-harvest products (conservation of stocks, processing, marketing) can be more significant in increasing farm productivity and 
remuneration of family labour than improving production processes. Innovation is thus also needed in these areas.

Innovation may originate from outside the farm. This type of innovation can then be popularized and disseminated by technicians. It can also be endogenous in origin, driven by the farmers themselves. But often, it results from a combination of both, either through work jointly undertaken by farmers and technicians (innovation is then said to be co-constructed), through a deferred implementation over time (an exogenous innovation proposed at a given moment and then rejected by the farmers can be appropriated and transformed by an individual or by a group several years later), or through an implementation in a different location (an endogenous innovation in one area can be disseminated by technicians in another area where it is unknown).

Farmers innovate depending on different parameters. First, in the case of an exogenous innovation, they evaluate its utility using their own yardsticks. Experts have proposed several assessment criteria for evaluating the utility of an innovation. Mendras and Forsé (1983) propose five of them: What are the relative benefits of adopting the innovation compared to the initial situation? How compatible is it with the existing system? How complex is it to implement and use? How easy is it to try out in the context of the farmer willing to innovate? If someone else has adopted it already, can it be easily observed at work? These criteria reflect the farmers' concerns with the degree of complexity of the innovation and the level of risk in adopting it. Second, the farmer's resources (land, water, labour, capital, knowledge, skills, social network) determine his ability to implement the changes necessary to innovate. Studies on farming systems focus on this aspect (Jouve and Mercoiret, 1987). Third, the motivation to change is equally critical. For example, research in Benin (de Romemont, 2014) shows that different farmers who access management advice for family farms may have different profiles in terms of their strategic vision, which includes a vision of their project of change and of the possible paths to implement it. The farmer's profiles - passive, reactive, constrained imaginative, proactive - appeared to be more important than his farm's resources in determining his willingness for change. Fourth, the external environment (physical environment, market conditions, regulations, social norms and values) also plays a key role in his 
ability to innovate. As a result, innovation cannot be simply thought at the level of the individual, but must incorporate interactions with other actors. Darré (1996) attaches great importance to exchanges and debates within producer groups (professional dialogue networks) to explain the dynamics of innovation. Nevertheless, interaction with peers to create new norms and validate new ways of doing things is not sufficient; innovation requires interactions with different kinds of actors. For example, the simple introduction of a new maize variety requires taking into account the relationship not only with the seed supplier but also with vendors of fertilizers and pesticides suitable for the new variety. A transition to organic farming requires contractual agreements with certifiers and negotiations with buyers in new value chains. Finally, the adviser, a third party intervening in support of the farmer, can also foster innovation processes.

\section{Determining a farmer's capacity to innovate}

The theory of adaptive behaviour (Brossier et al., 1997), based on a comprehensive vision of the farm, models the functioning of the farm by taking into account the environment (constraints and advantages), the project of the farmer and his family (more or less clearly defined and coherent), the family situation (characteristics that will encourage the farmer to act or, on the contrary, limit his possibilities of action), and the farm's situation (constraints and advantages). It is the individual farmer's perceptions of his situation and his project that are considered as determining factors in the management of the farm. This theory proposes a model that works by double adaptation, between the evolution of the farmer's situation and that of his project. In this perspective of management, reflection, decision making and action are part of the same process of continuous adaptation. This model is useful for identifying the capacities needed for the farmer and his family to implement their innovative project.

The first capacity conducive to innovation is one that allows the farmer to formulate a strategic vision of the changes to be made. Building on previous research (Torset, 2005), de Romemont (2014) defines strategic thinking as 'a process of creating meaning, in and for action' that helps the farmer understands his environment. It allows him to develop and revisit the vision 
of his project and to implement strategic actions related to this vision by adapting these actions over time, consistent with his perception of the environment. The farmer develops a strategic vision with the intention of influencing his environment by creating opportunities for himself in this environment in order to turn his vision into reality. The farmers' strategy development is thus an emerging, non-linear and complex process (de Romemont, 2014).

The second capacity required to innovate is the farmer's ability to carry out a project. It is based on the acquisition and building up of technical and managerial skills (Faure et al., 2012). Technical skills allow him to make the right choices of changes in his activities (cultivation, livestock husbandry, processing of products). Managerial skills make it possible to plan actions, to take tactical decisions (at the level of a single agricultural season) or strategic decisions (at the level of several agricultural seasons), to monitor actions in order to make course corrections and to evaluate the results on the basis of indicators that make sense to him in the specific context of his project.

The third capacity required to innovate is the ability to collaborate. It is based on the acquisition of inter-personal skills in order to widen the social network of the farmer and his family. He is then better placed to obtain access to resources (physical and cognitive), generate new actionable knowledge, negotiate and enter into business partnerships, coordinate with other actors to undertake collective actions, or engage in advocacy activities and thus influence the organizational and institutional landscape (Leeuwis and van den Ban, 2004 ).

\section{The adviser's role in and advisory approaches for strengthening innovation capacities}

A variety of methods and tools can be used to build up a farmer's capacity to innovate. Methods refer here to the procedures for organizing advisory activities (sharing knowledge, providing advice, strengthening learning processes). Tools refer here to technologies used as part of an advisory method. Tools may include 'soft' technologies (indoor meetings, field visits, mobilizing farmers as trainers) and 'hard' technologies (data sheets, 
information systems, computer models) (Faure et al., 2012). The choice of methods and tools depends on the adviser's objective and reflects his approach. We propose a typology of different advisory approaches: knowledge transfer, decision support, problem solving, capacity building, accompaniment and support, and mediation (Table 11.1). Which approach is used in a particular situation depends, among other factors, on:

- the type of problem that the actors wish to solve (simple versus complex) and the type of solution they want to or can implement (standardized versus co-constructed);

- the goal of the adviser and his organization as concerns capacity building and empowerment of actors.

Each approach involves a specific type of interaction between the adviser and the farmer(s) (simple $v s$ intense, rare $v s$ frequent) and may lead to the use of particular advisory tools. The cost of providing advice and the number of farmers (many vs few) with access to advisory systems depend in part on these parameters.

Table 11.1. Typology of different advisory approaches.

\begin{tabular}{|c|c|c|c|c|c|}
\hline \multirow[b]{2}{*}{$\begin{array}{l}\text { Objective of } \\
\text { the advice }\end{array}$} & \multirow[b]{2}{*}{$\begin{array}{l}\text { Methodological } \\
\text { approach }\end{array}$} & \multicolumn{4}{|c|}{ Key elements of the approach } \\
\hline & & $\begin{array}{l}\text { Cases for } \\
\text { which the } \\
\text { approach is } \\
\text { especially } \\
\text { relevant }\end{array}$ & $\begin{array}{l}\text { Actors } \\
\text { who } \\
\text { decide the } \\
\text { theme of } \\
\text { the advice }\end{array}$ & $\begin{array}{l}\text { Characteristics } \\
\text { of the advice }\end{array}$ & $\begin{array}{l}\text { Examples } \\
\text { tools }\end{array}$ \\
\hline $\begin{array}{l}\text { Knowledge and } \\
\text { technology } \\
\text { transfer }\end{array}$ & $\begin{array}{l}\text { The adviser tells } \\
\text { the farmer what } \\
\text { to do and } \\
\text { supervises the } \\
\text { farmer }\end{array}$ & $\begin{array}{l}\text { If the } \\
\text { problem } \\
\text { and the } \\
\text { solutions } \\
\text { are known } \\
\text { If the } \\
\text { farmers are } \\
\text { ready and } \\
\text { able to use } \\
\text { the advice }\end{array}$ & $\begin{array}{l}\text { External } \\
\text { actors, in } \\
\text { general }\end{array}$ & $\begin{array}{l}\text { Standardized, } \\
\text { focusing on } \\
\text { individuals }\end{array}$ & $\begin{array}{l}\text { ICTs, radiı } \\
\text { television, } \\
\text { newspaper } \\
\text { training, } \\
\text { demonstra } \\
\text { (or a } \\
\text { combinatic }\end{array}$ \\
\hline & & $\begin{array}{l}\text { If the } \\
\text { problem is }\end{array}$ & & & \\
\hline
\end{tabular}




\begin{tabular}{|c|c|c|c|c|c|}
\hline $\begin{array}{l}\text { Decision } \\
\text { support }\end{array}$ & $\begin{array}{l}\text { The adviser } \\
\text { offers options } \\
\text { and the farmer } \\
\text { decides }\end{array}$ & \begin{tabular}{|l} 
known and \\
various \\
solutions \\
are possible \\
depending \\
on the \\
situation of \\
each farmer \\
If the \\
farmers are \\
ready and \\
able to use \\
the advice
\end{tabular} & $\begin{array}{l}\text { External } \\
\text { actors, in } \\
\text { general }\end{array}$ & $\begin{array}{l}\text { Partially } \\
\text { adapted to the } \\
\text { situation }\end{array}$ & $\begin{array}{l}\text { Computer } \\
\text { models, } \\
\text { simulation } \\
\text { tools }\end{array}$ \\
\hline \multirow[t]{2}{*}{ Problem solving } & $\begin{array}{l}\text { The adviser co- } \\
\text { produces the } \\
\text { advice with the } \\
\text { farmers }\end{array}$ & $\begin{array}{l}\text { If a problem } \\
\text { identified } \\
\text { by the } \\
\text { actors } \\
\text { requires a } \\
\text { particular } \\
\text { analysis and } \\
\text { the } \\
\text { solutions } \\
\text { are either } \\
\text { known, but } \\
\text { have to be } \\
\text { adapted to } \\
\text { the local } \\
\text { situation } \\
\text { once the } \\
\text { diagnosis } \\
\text { has been } \\
\text { conducted, } \\
\text { or have to } \\
\text { be invented } \\
\text { with the } \\
\text { actors }\end{array}$ & $\begin{array}{l}\text { External } \\
\text { actors or } \\
\text { local actors } \\
\text { (depending } \\
\text { on the } \\
\text { case) }\end{array}$ & $\begin{array}{l}\text { The problem is } \\
\text { co-diagnosed } \\
\text { and the } \\
\text { solutions are } \\
\text { co-constructed } \\
\text { by the farmers } \\
\text { and the advisers }\end{array}$ & $\begin{array}{l}\text { Participatc } \\
\text { diagnostic } \\
\text { tools such } \\
\text { problem tr } \\
\text { and solutic } \\
\text { trees } \\
\text { Planning, } \\
\text { monitorin } \\
\text { evaluation } \\
\text { tools }\end{array}$ \\
\hline & $\begin{array}{l}\text { The advisor } \\
\text { relies on }\end{array}$ & $\begin{array}{l}\text { If it is } \\
\text { useful to } \\
\text { make } \\
\text { farmers } \\
\text { more } \\
\text { autonomous }\end{array}$ & $\begin{array}{l}\text { External } \\
\text { actors } \\
\text { (offer of }\end{array}$ & $\begin{array}{l}\text { The problem is } \\
\text { diagnosed and } \\
\text { the solutions are }\end{array}$ & $\begin{array}{l}\text { Managem } \\
\text { tools for } \\
\text { tactical or }\end{array}$ \\
\hline
\end{tabular}




\begin{tabular}{|c|c|c|c|c|c|}
\hline $\begin{array}{l}\text { Capacity } \\
\text { building }\end{array}$ & $\begin{array}{l}\text { learning } \\
\text { processes to } \\
\text { help farmers } \\
\text { become more } \\
\text { autonomous }\end{array}$ & $\begin{array}{l}\text { so that they } \\
\text { can solve } \\
\text { complex } \\
\text { problems } \\
\text { they may } \\
\text { encounter } \\
\text { on a regular } \\
\text { basis }\end{array}$ & $\begin{array}{l}\text { services) } \\
\text { and local } \\
\text { actors } \\
\text { (need for } \\
\text { services) }\end{array}$ & $\begin{array}{l}\text { elaborated by } \\
\text { the farmers who } \\
\text { change their } \\
\text { perceptions and } \\
\text { their way of } \\
\text { acting }\end{array}$ & $\begin{array}{l}\text { strategic } \\
\text { decisions, } \\
\text { including } \\
\text { strong trai } \\
\text { dimension }\end{array}$ \\
\hline $\begin{array}{l}\text { Accompaniment } \\
\text { and support to } \\
\text { initiatives and } \\
\text { projects }\end{array}$ & $\begin{array}{l}\text { The adviser } \\
\text { facilitates the } \\
\text { construction and } \\
\text { implementation } \\
\text { of the project }\end{array}$ & $\begin{array}{l}\text { If the } \\
\text { actors' } \\
\text { project is } \\
\text { complex } \\
\text { and } \\
\text { original, } \\
\text { and if new } \\
\text { solutions } \\
\text { have to be } \\
\text { found every } \\
\text { time }\end{array}$ & $\begin{array}{l}\text { Local } \\
\text { actors }\end{array}$ & $\begin{array}{l}\text { The diagnosis is } \\
\text { undertaken } \\
\text { jointly and the } \\
\text { solution is co- } \\
\text { constructed by } \\
\text { the farmers (or } \\
\text { other rural } \\
\text { actor) and the } \\
\text { adviser }\end{array}$ & $\begin{array}{l}\text { Self-diagn } \\
\text { mental ma } \\
\text { developme } \\
\text { and action } \\
\text { plans }\end{array}$ \\
\hline $\begin{array}{l}\text { Mediation } \\
\text { between actors } \\
\text { and conflict } \\
\text { resolution }\end{array}$ & $\begin{array}{l}\text { The adviser } \\
\text { plays a role of } \\
\text { facilitator and } \\
\text { enables } \\
\text { interactions } \\
\text { between actors }\end{array}$ & $\begin{array}{l}\text { If the } \\
\text { problem is } \\
\text { complex } \\
\text { and the } \\
\text { solution } \\
\text { depends on } \\
\text { getting } \\
\text { several } \\
\text { groups of } \\
\text { actors to } \\
\text { come to an } \\
\text { agreement }\end{array}$ & & $\begin{array}{l}\text { The diagnosis is } \\
\text { undertaken } \\
\text { jointly and the } \\
\text { solutions are } \\
\text { co-constructed } \\
\text { by the farmers } \\
\text { (or other rural } \\
\text { actor) and the } \\
\text { adviser }\end{array}$ & $\begin{array}{l}\text { Network n } \\
\text { analysis of } \\
\text { relationshi } \\
\text { between } \\
\text { actors, } \\
\text { negotiation } \\
\text { mechanisn } \\
\text { role plays, } \\
\text { modelling }\end{array}$ \\
\hline
\end{tabular}

Most approaches can be applied either through individualized interactions between the adviser and the farmer, in order to customize the advice to the situation, or through interactions within farmers' groups, in order to foster exchanges between peers with the aim of strengthening collective learning. However, some approaches used to advise a farmer or a farmer group may be better suited than others to solve problems involving multiple actors of a heterogeneous nature (mediation between actors and conflict resolution, see 
Chapter 12). Two points deserve highlighting, however. First, the same adviser need not choose the same approach all the time. Thus, an adviser, with the same target audience, can at some point choose a problem-solving approach and another time a capacity-building one, or even a simple knowledge transfer. Thus, the adviser can use a range of approaches to achieve the objectives assigned to him by the farmer or his advisory organization. Second, and limiting the scope of the previous statement, the choice of an approach also depends on the objectives of the advisory organization (Compagnone et al., 2009). Thus, some advisory organizations seek to apply rules on farmers that have been developed by others (a downstream firm that wants to ensure that the farmers' products are of a certain quality, a public service that promotes administrative or environmental standards, etc.). Other organizations can clearly deploy a capacity-building or a support approach (non-governmental organization wishing to implement agroecological practices based on the knowledge of farmers, association supporting the setting up in agriculture of people from outside the world of agriculture, etc.).

\section{Wwo case studies of advisory services}

In this section, we discuss two case studies in providing advice. One pertains to building up the capacity of farmers so that they can manage their farms better (Faure and Kleene, 2004) and the other to supporting the project of setting up in part-time agriculture of multi-active persons (Gasselin et al., 2013). We then draw lessons from these cases.

\section{Building up farmers' management capacities: the case of management advice for family farms (MAFF) in Africa}

\section{Context and objectives of MAFF in Africa}


A variety of actors, such as non-governmental organizations, producer organizations, cotton companies, and ministries of agriculture, have been involved in providing management advice for family farms (MAFF) since the 1990 s in several West African countries. MAFF aims to revamp the traditional approaches of agricultural advisory services which are considered too top-down in nature. The aim is to empower the farmers and build up their capacity to innovate so that they can better manage their farms' resources (land, labour, inputs, finances) and their activities, both agricultural (crops and livestock) and non-agricultural. MAFF is also designed to support farm initiatives and projects.

\section{Principles of intervention, methods and tools of MAFF in Africa}

MAFF is based on the use of participatory methods, allowing farmers to analyse their own practices concerning the different aspects of their farms (production, processing, marketing, etc.), and their technical and economic performances. The principles behind this approach originate from the management sciences and divide the process into several phases: analysis, planning, monitoring, adjustment and evaluation. Analysis and decision support tools are most often based on data recorded by farmers with the help of advisers. The data are sometimes processed on computers by the advisers to refine the analyses. MAFF tools and methods are adapted to the local context, taking into account the objectives of the main actors involved in the implementation of MAFF, and the human and financial resources available.

MAFF is delivered by advisers, often supported by farmers who play the role of facilitators. To be able to do so, the advisers must gain mastery over the technical contents of the advice (production activities, farm management), modalities of providing advice (participatory methods, learning processes, intermediation with other service providers), and the management of interpersonal relationships (listening, empathy, dialogue). Identifying, training and funding such advisers remains, however, a major challenge in Africa. 


\section{MAFF-stimulated innovations in Africa}

The changes farmers attribute to MAFF pertain to farming practices, management practices of the farm and the family budget, and strategic farm management. Innovations are therefore not only technical, leading to better performance of crops and livestock herds, but also organizational, at the farm level, leading to better management of financial resources and labour. Innovations such as these are often incremental in nature. In some cases, however, MAFF can lead to more radical innovations, involving strategic changes in farm functioning and the emergence of new production systems. Even though MAFF does not explicitly address the collective dimension of innovation, it can often strengthen farmer organizations, since some participants rise to leadership positions within their organizations due to their enhanced capacities.

\section{Supporting the progressive setting up in part-time agriculture: the case of multi-active persons in France}

\section{Context and objectives of providing advice to multi- active persons in France}

The setting up in agriculture of people from outside the agricultural world is a significant phenomenon in France and raises specific questions. These new farmers, often with multiple jobs and skills, usually leave their territories to embark on agriculture. Due to the uniqueness of their situation and the gradual nature of the process of undertaking agricultural activity, they pose new challenges for the support-providing community. The following issues have to be tackled head-on:

- all the various dimensions of the activity (organization of work, technical and commercial options, taxation, family economics, choice of residence, of territory, of occupation, of consumption, etc.);

- the uniqueness and diversity of their motivations and resources (especially 
in terms of skills, networks, funding capacities);

- the progressive nature of the implementation of agricultural and nonagricultural activities over several years (constituting a system of activities), which involves taking into account how the person is coping with the new activities, the progress of his project and his relationship with the adviser.

The challenge of providing support is to clearly define household's farming project, first with the project's initiator himself, then with the various actors with whom he is in contact. The approach is based on a redesigned accompaniment framework (approaches of accompaniers, main principles, temporality, evaluation, etc.), which needs to legitimized by the actors of the territorial support services system.

\section{Principles of and tools for the accompaniment of multi-active persons in France}

The approach allows the farmer to clarify and strengthen his motivations. The support (or accompaniment) is therefore primarily a relationship mechanism allowing the accompanier and the project's initiator to work together to cobuild the project. This accompaniment consists of iterations between intentions, changes and the expected goal during a reflexive evaluation. In this sense, accompaniment is neither advice, nor expertise, nor training, nor diagnosis, but a process that harmonizes a set of diverse practices adapted to each phase of the project (Paul, 2002). The ethical framework that the accompanier must respect guarantees the process; it includes confidentiality, an inter-personal relationship, the preservation of the 'enigma of the other', a voluntary commitment, but also flexible mechanisms in order to adapt to particular situations.

In southern France, this accompaniment approach, co-built by researchers and associations supporting the setting up in agriculture of persons from outside the world of agriculture (Association for the development of agricultural and rural employment of Languedoc-Roussillon, Airdie[32]), relies on three reflexive tools, whose flexibility is guaranteed because of the possibility of instrumentation that is inherent to them (Dalmais et al., 2015). 
The first tool helps determine the motivations and skills of the person, the second the project's territorial anchoring, and the third the sustainability of the system of activities which is planned by the initiator. In a situation of uncertainty, these tools are designed to build up the capacity of action of the individual being supported.

\section{Innovations facilitated by the accompaniment of multi-active persons in France}

Accompaniment helps identify and support initiators of innovative projects in their relationships with the market, work and the territory (Tallon et al., 2013). The new relationship with the market appears in particular in the forms of production for self-consumption and non-market exchanges which form the basis of certain projects. The new relationship with work is often expressed in the meaning and motivations assigned to the professional project, the paradoxical link to salaried work, the mastery of the calendar of activities (seasonality, etc.), the access to different forms of financing, as well as in the management of contingencies and uncertainties. The new relationship to the territory is visible in new ways of living and of managing the landscape, in the mobilization of territorial resources and in the reliance on specific networks.

\section{Lessons from these two cases}

Management advice for family farms focuses, as its name explicitly states, on farm management. The issues to be addressed are defined through dialogue between the farmer and the adviser as also, in part, by the advisory organization. There is a deliberate focus on the creation of learning situations so that the farmer's managerial capacities can be built up and he becomes more autonomous. To this end, the adviser alternates moments of training and moments of interaction to encourage reflexive processes. The method is standardized in order to orient advisers and therefore can be used with a variety of adviser profiles, thus facilitating the dissemination of the approach to a wider audience. The tools are aids for reflection and decision making. 
They structure thinking and reasoning by helping the farmer take management decisions; there is no standardized technical or managerial solution but an adaptation to each farmer's situation. The innovations facilitated by MAFF are generally incremental in nature and pertain to farming techniques and the management of farm resources. However, the technical and economic performances of the farm can be greatly improved as the farmer gradually builds up his managerial capacities thanks to MAFF (de Romemont, 2014). The most proactive farmers can embrace more radical innovations. The collective dimension is however absent from MAFF, which can engender tensions between actors or make it impossible to address problems at the scale of the territory.

Accompaniment of the creation of agricultural activity always focuses on both the project (feasibility, necessary resources, objectives, etc.) and the person (sense of the activity for the initiator, skills, representations, etc.). It therefore has a broad aim because the objectives to be attained have to be defined along the way, depending on the progressive maturity of a life and activity project, and on the evolution of the capacity to act of the concerned individual or household. The adviser, renamed 'accompanier', must possess capacities of listening and reformulation. He must demonstrate empathy and distancing. These skills require training that conventional agricultural education rarely offers, but which can be acquired through certain professional training conducted by associations. The tools available encourage reflection and help to make regular diagnoses, before and during the action. Some are intended to serve as a unifying thread all through the support. Innovations are often incremental, affecting the organization of work or the balance among activities, but they can also be radical, helping innovative activity systems emerge. While the collective dimensions of the project are taken into account, in particular by paying attention to networks and the territory, the accompaniment remains mainly oriented towards the individual.

\section{Conclusion: the choice of an advisory approach and innovation}

Agricultural advice can be based on different approaches, which are 
characterized by the extent to which farmers' demands and knowledge are taken into account and the importance accorded to support learning activities and to empower farmers. The choice of an approach depends not only on the nature of the problem to be addressed and the solutions to be implemented, but also on the advisers' capacities, on the objectives set by the advisory organizations, and on the mechanisms of governance and funding of advisory systems. Agricultural advice promotes innovation on the farm or, more broadly, within the activity system, leading to new farming practices, new ways of managing the farm's resources, and new relationships with the outside world. In some cases, innovation can be described as ordinary because it is undertaken by individuals who modify their perception of their farms and their environment and change their practices to achieve an objective they have defined. But innovation can also be radical, when the advice leads to a transformation of the production system or the activity system. Nevertheless, even though agricultural advice is a lever for bringing about change, it does not facilitate all forms of innovation and, in particular, does not facilitate those that require the creation of new relationships between heterogeneous actors within a value chain or territory. Links between the world of agricultural advice and that of support of collectives for territorial development are yet to be developed.

\section{W Bibliography}

Brossier J., Chia E., Marshall E, Petit M., 1997. Gestion de l'exploitation agricole familiale. Eléments théoriques et méthodologiques. Enesad-Cnerta, Dijon, $215 \mathrm{p}$.

Chambers R., Pacey A., Thrupp L.A., 1989. Farmer first. Farmer innovation and agricultural research. Intermediate Technology Publication, London.

Compagnone C., Auricoste C., Lemery B. (eds), 2009. Conseil et développement en agriculture. Quelles nouvelles pratiques? Éditions Quæ, Educagri, Versailles, Dijon.

Dalmais M., Gasselin P., Cerf M., 2015. Concevoir des outils pour l'accompagnement individuel à la création d'activités en agriculture : quelles 
caractéristiques et fonctions attendues ? Pour, 227, 22-30.

Darré J.-P., 1996. L'invention des pratiques dans l'agriculture. Karthala, Paris, $194 \mathrm{p}$.

De Romemont A., 2014. Apprentissage et réflexion stratégique des producteurs agricoles : construction de la proactivité dans le conseil à l'exploitation familiale au Bénin, $\mathrm{PhD}$ thesis, Montpellier-SupAgro.

Dorward P., Shepherd D., Galpin M., 2007. The development and role of novel farm management methods for use by small-scale farmers in developing countries. Journal of Farm Management, 13, 123-34.

Faure G., Desjeux Y., Gasselin P., 2012. New challenges in agricultural advisory services from a research perspective: a literature review, synthesis and research agenda. Journal of Agricultural Education and Extension, 18(5), 461-492.

Faure G., Kleene P., 2004. Lessons from new experiences in extension in West Africa: management advice for family farms and farmers' governance. Journal of Agricultural Education and Extension, 10, 37-49.

Gasselin P., Tallon H., Dalmais M., Fiorelli C. (eds), 2013. Trois outils pour l'accompagnement à la création et au développement d'activités : Trajectoire, Cartapp et Edappa. Application à l'installation en agriculture. Inra, Cirad, Adear-LR, Montpellier Supagro, Airdie, région LanguedocRoussillon, Montpellier, $151 \mathrm{p}$.

Hocdé H., Miranda B., 2000. Los intercambios campesinos : más allá de las fronteras... ! seamos futuristas. IICA-Cirad-GTZ, San Salvador, 294 p.

Jouve P., Mercoiret M.-R., 1987. La recherche-développement : une démarche pour mettre les recherches sur les systèmes de production au service du développement rural. Les Cahiers de Recherche-Développement, $16,8-15$.

Leeuwis C., Aarts N., 2011. Rethinking Communication in Innovation Processes: Creating Space for Change in Complex Systems. Journal of 
Agricultural Education and Extension, 17(1), 21-36.

Leeuwis C., van den Ban A., 2004. Communication for innovation: rethinking agricultural extension, Third edition, Blackwell Publishing.

Mendras H., Forsé M., 1983. Le changement social. Armand Colin, Paris.

Paul M., 2002. L'accompagnement, une nébuleuse. L'accompagnement dans tous ses états. Éducation Permanente, 4(153), 43-56.

Röling N., Jong F.D., 1998. Learning: shifting paradigms in education and extension studies. Journal of Agricultural Education and Extension, 5, 14361.

Schumpeter J., 1934. The theory of economic development: an inquiry into profits, capital, credit, interest, and the business cycle. New Brunswick, New Jersey: Transaction Books. (Translated from the 1911 original German, Theorie der wirtschaftlichen Entwicklung.)

Tallon H., Dulcire M., Dubien A., 2013. Penser la pluri-activité dans le HautLanguedoc : registres de justification et dispositif d'accompagnement. Revue d'économie régionale et urbaine, 1, 93-117.

Torset C., 2005. La réflexion stratégique : objet et outil de recherche pour le management stratégique. XIV ${ }^{\mathrm{e}}$ conférence internationale de management stratégique. Angers, France, $30 \mathrm{p}$.

\section{Chapter 12}

\section{The ComMod and Gerdal approaches to accompany multi-actor collectives in facilitating innovation in agroecosystems}




\section{Guy Trébuil, Claire Ruault, Christophe-toussaint SOULARD AND FRANÇOIS BousqueT}

Summary. The ComMod (Companion Modelling) and Gerdal (Group for Experimentation and Research: Development and Local Action) approaches facilitate the emergence of solutions and action plans negotiated within peer groups or arenas of heterogenous actors by stimulating interactions between their participants. Their theoretical, ethical and methodological foundations are described, and two case studies illustrate their use. In order to help practitioners reflect on their mode of intervention to collectives, the comparative analysis of these approaches highlights the key points of their accompaniment, such as the initial situation, creation of relevant collectives, management of processes, sharing of knowledge and points of view, monitoring and evaluation of effects, and strengthening of the capacity of collective innovation.

While new approaches to innovation regard it as a reflective process involving heterogenous actors, the way of accompanying these processes is still the subject of an open debate: with which tools, based on which theoretical reference frameworks and which ethical principles? This chapter examines this problem on the basis of two approaches that have been implemented for many years, in different geographical contexts in the countries of the Global North as well as those of the Global South. The first is companion modelling (ComMod) and the second is the Group for Experimentation and Research: Development and Local Action (Gerdal). The analysis of these methods provides information on the theoretical, ethical and practical foundations mobilized to facilitate the emergence of acceptable solutions or negotiated action plans within peer groups or arenas of heterogenous actors. Both approaches are based on the facilitation of interactions amongst actors confronted by a problem, whether internal to the collective, or in the form of an external injunction imposed on a given social group.

Following a brief presentation of the approaches, two case studies are used to demonstrate their implementation. A comparative analysis of such accompaniment processes then focuses on a few key points to help practitioners reflect on their mode of intervention to collectives.

\section{Key features of the ComMod and Gerdal}




\section{approaches}

\section{Companion modelling (ComMod)}

In 1996, several researchers working on the collective management of renewable resources started to build an intervention approach for complex territorial systems, which they named companion modelling (ComMod)[33]. This type of modelling is characterized by a transdisciplinary analysis of the object under study, focusing on the interactions between actors and the coviability of ecological and social dynamics. The researchers relied on collaborative modelling to catalyse interactions between researchers from different disciplines, as well as interactions between them and local actors. The initial implementations offered models that incorporated knowledge from different disciplines, and were quickly followed by dozens of case studies in many countries, covering a variety of themes. They favoured interactions between different holders of knowledge, researchers and local actors, through the use of different tools such as surveys, interviews, group exchanges, conceptual modelling workshops, role-playing games, multi-agent computer simulation models, etc. It then became necessary to clarify the initial postures of the researchers involved in the accompaniment and support of individual or collective actors, each with his particular representations of the situation, with different objectives and influence in the negotiation of solutions. Even though participating as a facilitator, the practitioner-researcher is one of the participants interacting in the ComMod process. In addition to favouring the production and sharing of knowledge, when the participants deem it necessary, the process aims to change the initial unsatisfactory situation by transforming the modalities of interactions between the actors and the common resource to be managed, and/or the forms of existing socioeconomic relationships (Collectif ComMod, 2005).

\section{ComMod theoretical references}

This approach is inspired by:

- the sciences of complexity (interactions and unpredictability of trajectories 
of socio-ecological systems);

- constructivism (taking into account different points of view of actors);

- post-normal science (importance of the quality of the process of coconstruction of collective decisions);

- the theory of resilience of socio-ecological systems and their adaptive management involving production and knowledge sharing;

- self-organization and social learning (co-design of a shared representation and implementation of a joint action plan);

- the patrimonial approach and mediation which suggest the use of the model, as a third-party mediator translating the parties' perceptions to facilitate exchange.

The ComMod model is used to construct a common representation of the system to be managed and to explain its dynamics. Once it is validated with the concerned actors, it can be used to analyse scenarios that explore possible future situations (Collectif ComMod, 2009).

\section{Collaborative and integrative companion modelling}

The use of protocols of interaction between actors and multi-agent simulation models as key accompaniment tools is an original feature of ComMod processes (Bousquet et al., 2002). They are used to conceptualize a common representation of the situation by sharing points of view. Their implementation, as computer simulations and/or role-playing games, not only favours individual and collective learning, but also the group's creativity to identify desirable scenarios and the paths to follow to achieve them. The ComMod process is located upstream of the collective decision-making or of the technical action plan aimed at achieving the desired state of the system, and promotes the adaptive management of common resources.

\section{Sequential, iterative and evolutionary accompaniment processes}


The ComMod processes are often preceded by a stage of raising the awareness of the parties concerned of the issue at stake regarding this approach, and by the ex ante evaluation of the relevance of such a process and of its feasibility in the actual intervention circumstances. This is followed by a chain of iterative sequences that are evolutive; the first focuses on key issues arising from the initial analysis of the problem, and succeeding ones on new issues that emerge during the modelling and participatory simulation activities carried out previously. Each sequence consists of several phases (Box 12.1) aimed at the analysis of the problem, the co-construction of its representation into a conceptual model, and its implementation and use in the form of participatory simulations (Etienne, 2014).

\section{Box 12.1. Phases of a sequence of a companion modelling process}

1. Definition of the key issue to be examined with the process's proponents.

2. Inventory of available relevant information (scientific data, expertise, local knowledge, etc.) and complementary diagnostic surveys.

3. Obtention and clarification, through surveys and interviews, of knowledge relevant to the conceptual modelling.

4. Co-design of the conceptual model with the concerned stakeholders.

5. Choice of the multi-agent tool (computerized or not) to implement this conceptual model.

6. Verification, validation and calibration of the model with the stakeholders.

7. Identification and definition of possible scenarios with the participants.

8. Exploratory participatory simulations with actors.

9. Dissemination of the results of the process to the concerned local actors who did not participate in the workshops.

10. Continuous monitoring and evaluation of the effects and of the evolution of the situation.

11. Identification of new key issues (return to point 1) or/and negotiation of a collective action plan.

12. Training of facilitators in the use of the co-constructed collaborative modelling tools. 
Although they are often applicable on multiple scales, these processes have primarily concerned spatial entities ranging in size and scope from villages to small watersheds. Depending on their dynamics, the evolution of the context and the facilitation postures adopted, their duration varies from a few months to several years. On-going monitoring and evaluation mechanisms during the process and external ex post evaluations of their impact have revealed a variety of effects: awareness of a problem, improvement in self-confidence, widening of exchange networks, change in the mode of decision-making, adoption of new practices or rules of collective management, and organizational innovations ensuring their local regulation.

\section{Gerdal's help in formulating and resolving problems}

The approach proposed by the Group for Experimentation and Research: Development and Local Action (Gerdal)[34] was formulated in 1983, in a context in which the agricultural research community and agricultural organizations were underscoring the need for diversification of development models in agriculture in response to impasses created by agricultural modernization and by the organization of advisory services for farmers. Starting from a critical analysis of the model of social division of labour in the organization of agricultural development (distinction between those who think and those who execute) and the observation that farmers were facing a kind of domination by agricultural advisers, who were acting as votaries of technical-scientific knowledge (Darré, 1996), the Gerdal sociologists tried out, in several countries, an alternative approach to this diffusionist paradigm with the aim of helping farmers formulate and deal with the problems they encounter, and to increase their capacity for taking initiatives.

The Gerdal approach seeks to strengthen the activity of knowledge production and transformation through dialogue and collective reflection among peers in order to identify ways towards finding appropriate solutions and to be able to discuss them with other actors (Darré, 2006; Ruault, 1996). 


\section{Rethinking relationships between actors from the point of view of plurality of forms of knowledge}

Emphasizing the plurality of forms of knowledge entails, first of all, differentiating scientific and technical knowledge from actionable knowledge. It also means accepting the multiplicity of ways of knowing and perceiving reality. From an action perspective, this leads to a rethinking of relationships between technicians, researchers and farmers, as well as those between farmers and other actors, in terms of comparison and the use of different ways of analysing and evaluating situations and, consequently, of formulating problems. Paying attention to each actor's voice, to the way of saying things, is thus central to the proposed intervention tools.

\section{Linking social dynamics and dynamics of norms and practices in peer groups}

On the basis of case studies, the Gerdal approach has shown that change in agriculture is a collective process of producing and transforming norms (rules of action), undertaken by the practitioners themselves in response to problems concerning action. This process is, in particular, carried out on an everyday basis in dialogues where, on the basis of the diversity of ways of perceiving and acting, there are revealed differing points of view regarding a given problem, change of context or injunction in order to arrive at suitable solutions. The nature of the debates, and what they produce in terms of knowledge, is correlated with the structure of the networks of relationships and the position occupied therein by individuals (giving them more or less a voice and power of initiative). In this way, the Gerdal approach aims to strengthen cooperation between farmers who do different things and do not occupy the same positions in professional networks.

\section{Creating conditions conducive to productive cooperation between actors}


These conditions refer, on the one hand, to the design of working mechanisms (with which social unit to work, with which bodies, at what scales, and to do what?), and, on the other, to carrying out activities to formulate the problems and find solutions (i.e., facilitating meetings, the most common form these activities assume).

To begin with, it is a matter of constituting relevant collectives, ensuring that their social configuration is appropriate to the nature of the problems to be addressed (Ruault and Lémery, 2008). These collectives are defined on a case-by-case basis relying, to the extent possible, on the practitioners' existing dialogue networks, and distinguishing between instances of practical discussion from those concerning policies and strategies. This step relies on analytical means (Table 12.1) to understand situations. Based on the sociological survey, the proposed tools aim to characterize the systems of actors and their socio-professional dynamics (kind of networks, multiaffiliations, levels of inter-knowledge, gaps in social positions, etc.), as well as the places and topics of the debates.

Table 12.1. Notions and tools for analysis and intervention used in the Gerdal approach.

\begin{tabular}{|c|c|}
\hline $\begin{array}{l}\text { Useful concepts to } \\
\text { understand and analyse } \\
\text { situations }\end{array}$ & Concepts and tools used to guide action \\
\hline $\begin{array}{l}\text { Individuals and social norms } \\
\text { Social configurations: local } \\
\text { professional group; dialogue } \\
\text { networks; multi-affiliations } \\
\text { Link between morphologies of } \\
\text { dialogue networks and the } \\
\text { dynamics of norms } \\
\text { Technical, scientific and } \\
\text { action-oriented points of view } \\
\text { and forms of knowledge } \\
\text { Practices and conceptions; } \\
\text { system of norms; } \\
\text { differentiating things, } \\
\text { situations and relationships to } \\
\text { things, to situations } \\
\text { Social positions and right to be }\end{array}$ & $\begin{array}{l}\text { Notion of relevant collective; conditions for mobilizing } \\
\text { actors and to limit their selection } \\
\text { Notion of addressable problem: transition from concerns } \\
\text { or wishes to concrete questions allowing action ('How to } \\
\text {...?') } \\
\text { The Say, Connect, Propose functions; methodological } \\
\text { aid: } \\
\text { The dynamics of speech; the dual value of arguments: } \\
\text { social value (weightage given to the arguments } \\
\text { depending on the social position of the speaker) and } \\
\text { intrinsic value (weightage given depending on the } \\
\text { relevance to the problem being addressed) }\end{array}$ \\
\hline
\end{tabular}




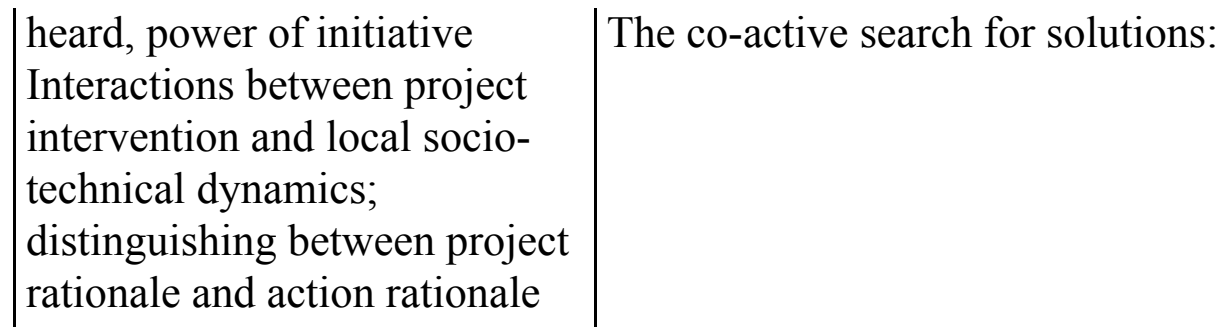

The management of collectives is then facilitated by the use of methodological tools to support reflection (also called 'tools of co-active search for solutions') (Darré, 2006; Ruault and Lémery, 2009; Table 12.1), in order to enhance the effectiveness of collective reflection. These tools focus on speech (vector of thought), by promoting dialogue and the expression of different ways of perceiving, and thus of expressing things, and by managing the gaps in social positions (able to speak and opportunity to be heard) in order to make the most of this diversity. The first step is to analyse the situation and define the problems to be addressed, and then help change the way the problem is posed in order to widen the range of possible solutions. During the research, resources outside the group, especially scientific and technical knowledge, are mobilized as required. Their usefulness, however, depends on the conditions of linkage of the external contributions of knowledge to the questions which participants ask themselves in the context of the practical exercise of their activities, and on the feasibility of specific actions to be carried out.

\section{W Case studies of the accompaniment of multi- actor collectives}

\section{Use of ComMod to support a fodder revolution in Thailand}

The recent rapid transformations of the northern highlands of Thailand have created many land-use conflicts between government forest agents and herders practising extensive cattle rearing. The former are attempting to rebuild the forest ecosystem while the latter, encouraged by the strong demand for beef, want to continue with their livestock raising activity. 
During one such conflict between these parties in Nan Province, a companion modelling process was carried out over a two-year period, in order to share knowledge of the effects of extensive grazing on the growth of young trees and to identify new livestock rearing practices that could help both parties attain their respective goals (Dumrongrojwatthana and Trébuil, 2011).

\section{The situation of intervention}

Additional surveys were carried out by the team managing the process, consisting of researchers and their students, who were being trained in this approach, in the Hmong village of Doi Tiew, at different scales:

- at the scale of the grazed and/or replanted plot, to understand the dynamics of biomass with and without grazing;

- at the scale of the family farm, to understand the diversity of production systems and livestock rearing practices;

- at the landscape scale, to link recent changes in land use with the strategies of the institutions and actors intervening in this village territory (foresters, the new national park, the network of livestock traders, etc.).

The results helped researchers form their own opinion of this land-use conflict, and to build the first participatory modelling tool, based on a series of pictograms to represent local vegetation states that evolve over time and due to human actions.

\section{Initiation to conceptual modelling}

These pictograms were used in awareness-raising workshops on collaborative modelling held separately with foresters, on the one hand, and with Hmong livestock herders, most of whom had little formal education, on the other. Reconstructing the chronology of the state of vegetation, with human intervention and without, this set of cards was enriched by the addition of the states of vegetation used by these two actor groups as key indicators of the environment's productive potential. A conceptual model of changes in vegetation was thus gradually co-constructed in the form of a state transition 
diagram. Implemented as a multi-agent computer model, it was then used in a role-playing game to update, at each round of play, the vegetation types for every pixel of its visual interface. This game was the main intermediary object used to stimulate exchanges.

\section{First role-playing workshop facilitated by a computer simulation tool}

This first role-playing game had, as a visual interface, a simplified representation of the gradient of vegetation states (ranging from dense forest to orchards through annual crops and different types of fallow lands) of the most diverse part of the village's lands. The game was first enriched, and then validated, during an initial participatory simulation workshop with the herders in the village. Another session was held the following day with the majority of the herders and several forest agents (including the manager of the local reforestation unit) on neutral ground, in the district administrative offices. Simulations of forest replanting and cattle grazing practices showed the gradual colonization of extensive pastures by the forest. They led to the identification of a scenario for the future, acceptable to both parties, based on the introduction of artificial pastures of Bracharia ruziziensis, a technique that had long been available locally, but had yet to be adopted in the highlands.

\section{Second, expanded workshop, with a modified game and simulation tool}

The multi-agent computer model used for the role-playing game was modified to include the 'Bracharia pasture' option, and the game components were also adapted. On the request of herders, who had limited trust in the foresters, the arena of actors was expanded to include the district livestock technician, agents of the national park and those of the neighbouring Sob Khun Royal Project, who expressed interest in the approach and in observing its implementation as it pertained to a topic close to their concerns. This 
second workshop took place in the village school and brought livestock herders, foresters and park agents together for the first time. The results of the participatory simulations of the selected Bracharia scenario, with individual and collective herd management, allowed participants to come up with a concrete collective action plan. It integrated the knowledge of the technician, who was an expert in the envisaged fodder innovation. He also acted as a witness to the agreement between the parties. The plan of action was based on the provision by the foresters of a 10 ha fenced experimental plot, sown with Bracharia using inputs supplied by the livestock department, and grazed by a herd lent by some large herders, and managed collectively.

\section{An autonomous multi-agent model for training herders on this innovation}

A full-scale experiment of the new livestock system, involving collective management of grazing was thus jointly created. The final version of the roleplaying game was implemented in the form of a self-contained computer simulation tool playing the game. It was used by the local researcher and the herders who co-designed it to train other herders who had not participated in the process at the meetings of the villagers, and then to train a few small groups of herders who had not participated in the earlier stages of the process. The new system's co-builders were thus able to explain and discuss the fodder revolution proposed to intensify cattle rearing, while allowing forest replanting of the upper watersheds.

\section{Monitoring and evaluation of participation and knowledge sharing}

The logbook, maintained in the form of a spreadsheet by researchers, was used for monitoring and evaluation. It allowed to quantitatively show the intensity of the interactions between the actors, who had not been on speaking terms earlier, as well as the diversity of information exchanged during the process. Figure 12.1, in which the line thickness is proportional to 
the intensity of the actors' interactions, shows that more than $40 \%$ of the time was devoted to sharing the herders' empirical knowledge, previously largely ignored.
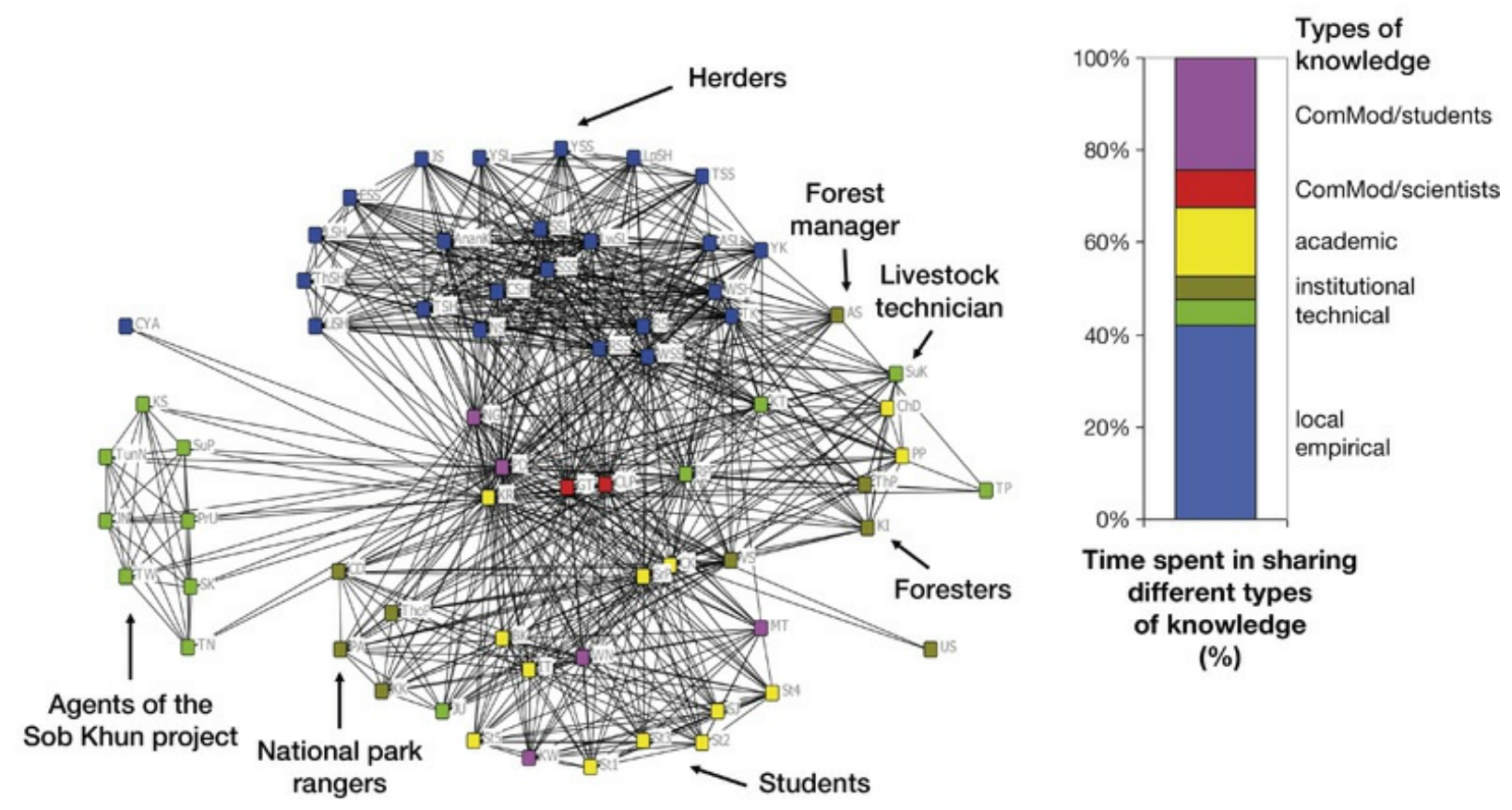

Figure 12.1. Interactions between different types of participants and diversity of knowledge exchanged during the ComMod process in Thailand.

\section{Use of the Gerdal approach for hillside maintenance in the Isère valley}

A deliberation was initiated between 2005 and 2008 by the elected members of an association of municipalities in the Isère valley in south-eastern France on the future of agriculture, in connection in particular with the revision and extension of the master plan of the Grenoble agglomeration. Based on a diagnostic study of the territory, conducted by the chamber of agriculture, a baseline appraisal of agriculture (number of farmers, farm characteristics, succession perspectives, etc.) and land use was undertaken, which resulted in the formulation of development objectives (maintaining a balance between agricultural activity and urbanization, maintaining open landscapes, etc.). The local elected officials, in an attempt to understand how to translate these 
objectives into action, deputed the development agents to work with the farmers and develop concrete proposals. It is around this aim, of engaging farmers to implement a public policy objective, that the Gerdal approach provided methodological support to the coordinating advisers of the South Grésivaudan Territorial Committee, the body in charge of the process.

In an effort to ensure that the proposals would have the full backing of the farmers, development workers raised several issues:

- at what scale should farmers be organized, since that of the Territorial Committee seemed too broad to them and did not correspond to their usual scales of action and social relations;

- who to invite, in order to engage people other than just professional managers;

- how can farmers' concerns be emphasized, since issues raised by elected representatives (such as that of the landscape) were not necessarily priorities for them;

- how to organize a dialogue with other actors of the territory (elected officials, in particular)?

\section{Constitution of a peer group}

Based on an identification of dialogue networks, it was decided to invite all farmers, at the level of one to three municipalities - which led to four parallel meetings - to define the working method on the problem to be addressed (formulated from a sharing of concerns and desires about the sustainability of their activities and agriculture in the territory) and then constitute issue-based groups and envisage possible solutions.

Following the first meetings, which saw the participation of between $25 \%$ to $50 \%$ of the farmers in each municipality, one of the issues formulated, selected for the Cras and Morette municipalities, was as follows: 'How to make hillside maintenance profitable without it being too expensive or labour intensive?' This issue engaged a working group for three years. Based on a detailed analysis of the constraints and the evolution of agricultural activities (overwork, low profitability of the hillsides, accessibility, access to water, 
etc.), this question helped translate a territorial challenge, formulated by elected officials in terms of maintaining open landscapes, into an issue that could be addressed by the farmers.

Several possible solutions were then studied, mobilizing different tasks: inventory of hillsides and their land uses, compilation of a list of farmers interested in maintaining cultivated plots in these areas, and a study of different maintenance options (shared employees, insertion-employment company, etc.). The project based on collective maintenance equipment was finally selected, followed by the search for suitable machinery from companies, cost studies, etc.

\section{From the local peer group to an extended collective and multi-actor meetings}

Since it was necessary to increase the number of farmers involved to make the project viable, the group's members made contact with farmers from neighbouring municipalities and with a cantonal Cuma (cooperative for the use of agricultural equipment). In addition, exchanges were organized with local elected officials to ascertain their position on the planned solutions and to study the possibility of including the municipalities in the collective equipment effort. The elected officials supported the project and formed the link to the association of municipalities.

This example shows that the configuration of working groups evolves as the problem is addressed and that discussion within multi-actor bodies is more productive the more it is based on previously elaborated points of view amongst peers, especially between farmers (Ruault and Lémery, 2008). It also shows that the 'appropriation', by the territory's actors, of a development goal formulated by others is contingent on a reflection that relies on the knowledge and analysis of circumstances in the field, based on their own relationship to the concerned situations.

This collective reflection is not a given and requires the facilitator to play an active role to help undertake this analysis, formulate addressable problems 
and build relationships necessary to solve them, produce new knowledge and, ultimately, help participants retain control over the progress of their research, while helping them negotiate solutions.

\section{Comparative analysis of the ComMod and Gerdal approaches}

The importance accorded to dialogues within actors' groups is a common feature between the ComMod (companion modelling) and the Gerdal (Group for Experimentation and Research: Development and Local Action) approaches. These diverse and evolving collectives represent, based on the subjects addressed, either groups of peers or multi-actor arenas. The challenge is to facilitate the exchange of knowledge, arguments, points of view and proposals to arrive at negotiated and acceptable solutions. Several key periods of these approaches require particular attention.

\section{Initial situation and enabling context for such approaches}

Changes in practices are processes of collective transformation of norms and rules in use. However, since the change towards an objective is always driven by one or more particular actors, it is necessary to characterize the request for change accurately (Who formulates it? What is the objective or the problem? Who is it addressed to?).

The ComMod and Gerdal approaches take into account the different points of view present, which represent different ways of understanding, describing and analysing situations. The involvement of the actors thus requires an initial stage to formulate the issue to be addressed. In the case of multi-actor processes to examine an issue, a productive discussion requires taking into account the manner in which each of the parties present formulates one or more specific problems in terms of their own room for manoeuvre and possibilities of action.

ComMod assumes that the initial points of view on the issue to be addressed 
are based on an incomplete knowledge of the agroecosystem, due to the actors' focus on their respective activities. Thus, for the forester, extensive grazing had a negative effect on the growth of young plantations (trampling, increased risk of fire), but it was perceived positively by the farmers (reduction of fire risk by limiting biomass, organic fertilization), which the researchers' diagnostic survey confirmed. This example illustrates the importance of a shared and galvanizing definition of the problem to be tackled so that the actors engage in work that can be translated into action.

\section{Setting up collectives that are relevant to the issue to be addressed}

Arriving at a consensus on what to work on is, of course, necessary, but it does not say much about who should be involved in the exchanges to create the knowledge and solutions that are acceptable to all. The composition of work collectives can be based on certain criteria of relevance of participants, such as their knowledge of the situation, their relationship with the issue, their representativeness, their legitimacy, or their social status, and, in particular, by taking the asymmetries between actors into account, i.e. how much of a voice, information, power, etc. do they have. However, these collectives are not fixed over time and can evolve depending on new questions raised and which have to be addressed.

For the Gerdal approach, support for arriving at a common point of view of a group of actors, especially those who are socially disadvantaged, is a necessary condition for cooperation. This implies a plurality of arenas of dialogue, with working sessions between peers alternating with multi-actor meetings. Special attention is also paid to the practical arrangements that encourage the actors' involvement, such as the choice of invited individuals, the way to contact them, the purpose of the invitation, the location and size of the meeting, etc.

The unpredictability inherent to such processes entails managing absences and refusals to participate, and adopting positions that facilitate cooperation. In the case of the ComMod approach applied in Thailand, given the impossibility of carrying out a first round of activities with all the actors, who 
were no longer on speaking terms, it was decided to first help the marginalized Hmong herders build their representation of the territory and test it in the form of role-playing sessions. At the end of this stage, the majority of them were able to defend their point of view in front of the foresters. Indeed, it was these herders who then wanted to expand the arena to include the livestock technician, for his knowledge and as a neutral observer to serve as a witness to the commitment made by the foresters for implementing the negotiated action plan.

\section{Key role of facilitators in accompanying such collectives}

The two cases described above illustrate the crucial role of the mechanisms' facilitation, alternating between periods of high and low interactivity, and evolving towards an enlargement of the collectives involved. While the definitions of facilitation are distinct - methodological assistance to aid deliberations, in the Gerdal approach, versus facilitator, non-neutral, participant just like others, in ComMod -, in both cases, the facilitation covers a variety of functions and refers to specific postures and skills, such as sociological analysis, support for group dynamics, and the organization of dialogue forums.

In the case of the Gerdal approach, the tools for methodological assistance to aid deliberation build up the capacity of the actors to express themselves verbally. While these tools help balance the amount of time each protagonist holds centre stage, they also orient discourse so that it is useful to action. To this end, the actors are encouraged to transcend preconceived ideas, clichés and dominant discourses in order to be more in sync with the experience and practical knowledge of people. Facilitation also aims to turn concerns into issues of action, to favour the expression of a wide range of ideas to open up new possibilities of solutions, and to organize what is being said in order to show the way forward for research. Particular attention is paid to topics that may crop up along the way that require research for information or specialized expertise. The facilitator helps evaluate this information, shows how it can contribute (or not) to solving the problem, modify its definition or the range of possible solutions. 
For its part, the ComMod process consists of a series of sequences centred on the analysis of a key question to be examined. This involves a sharing of knowledge, a representation of the system concerned and its implementation using relatively sophisticated tools (role-playing games, multi-agent computer simulation tools, etc.), used to simulate possible evolutions of the situation and to evaluate these scenarios using indicators chosen by the participants. Interactive modelling and participatory simulation workshops, held over a few days, alternate with longer periods of surveys and the (re)construction of tools. A reflexive and critical posture on the part of the facilitators uses the monitoring and evaluation periods to build alliances between peer groups instead of insisting on the simultaneous presence of all actors, for example. A significant flexibility in the calendar of activities is required to deal with changes in context or unforeseen events and in order to adjust to delays or roadblocks, as also to favourable accelerations.

\section{Sharing of know-how, knowledge and points of view}

The central role of dialogue in these two approaches helps express points of view, a precondition to cooperation between participants. It is not a matter of making compromises or creating consensus, but of identifying differences and lack of understanding, so that the debate of ideas is structured and leads to the exploration of a variety of possible solutions, and subsequently to the choice of the most acceptable scenario to implement.

These two approaches use different methods of formalizing knowledge. In the case of ComMod, various collaborative modelling tools are used as intermediary objects. In the case of the Gerdal approach, this formalization essentially involves modelling dialogue networks (prior to creating the collectives) and phases of organizing ideas generated by the groups during or after meetings. The reports of the meetings help to move on from one meeting to the next, or between the different groups of actors involved.

\section{Monitoring and evaluation}


This task ensures that the ethical and methodological principles of the approaches are adhered to.

The Gerdal approach, with its action-research orientation, reinforces its support to field teams with monitoring and evaluation tools which are useful to development agents. They help understand what is happening, the difficulties encountered as well as the progress made, in order to be able to adjust the course of action and, ultimately, to learn from it. These tools are useful for analysing not only an entire process (growth in participation, circulation of information between groups, emergence of tensions or cooperation, change in the positions of the actors, etc.), but also a particular moment, for example a meeting. It is a matter of linking the results obtained and the difficulties encountered with the configuration of the collectives and their functioning. The goal is to identify the potential for improvement that will be useful to actors in dealing with complex situations.

In the case of the ComMod approach, a dashboard to keep track of activities was used to record step by step their type, contents, participants, durations, results, etc. Because this dashboard is linked to a network-visualization computer application, this database helped monitor and quantitatively analyse the effects of these activities on the frequency of communications between participants, on their degree of engagement in the successive sequences, on the different types of knowledge in interaction, etc. (Figure 12.1). The evolution of these networks over time can help predict necessary inflections, or support emerging trends. The debriefings at the end of the simulation sessions are undertaken systematically in order to promote learning. And individual interviews are carried out to compare the characteristics of the situation on the ground that needs to be improved and its representation in the simulation tool used, to draw lessons from the results of the workshops held and to prepare follow-up phases of the participatory process.

\section{W Conclusion: similar objectives, but different ways to reach them}

The ComMod (companion modelling) and Gerdal (Group for Experimentation and Research: Development and Local Action) approaches 
have proven their ability, across numerous types of territories and themes, to build up the actors' capacity to deliberate on their situation and identify collective solutions. The facilitation of dialogue, the sharing of points of view and knowledge, the creation of forums of relevant actors, and the importance of managing and facilitating such processes are features common to both approaches. They differ in the manner in which they address situations and problems, as well as in the types of tools used. While the Gerdal approach can deal with a wide range of topics, ComMod is mainly designed to facilitate the management of renewable resources and belongs to the family of participatory simulation methods. The facilitators responsible for implementing either of these approaches need to work on the accompaniment posture and the skills required to place the actors in the field at the heart of innovation processes. ComMod's simulation tools require access to expertise that is sometimes difficult to mobilize at the right moment in order to build and modify these tools iteratively in response to actor requests. However, training programmes now exist to overcome this limiting factor. In the Gerdal approach, the mastery of sociological analysis and tools for methodological assistance requires prior training, but it can also be acquired through practical experience.

\section{Bibliography}

Bousquet F., Barreteau O., D’Aquino P., Etienne M., Boissau S., Aubert S., Le Page C., Babin D., Castella J.-C., 2002. Multi-agent systems and role games: collective learning processes for ecosystem management, In: Complexity and ecosystem management: The theory and practice of multiagent approaches (M. Janssen, ed.), Edward Elgar Pub., 248-285.

Collectif ComMod, 2005. La modélisation comme outil d'accompagnement. Natures Sciences Sociétés, 13, 165-168.

Collectif ComMod, 2009. La posture d'accompagnement des processus de prise de décision : références et questions transdisciplinaires. In: Modélisation de l'environnement : entre natures et sociétés (Hervé D., Laloë F., eds), Éditions Quæ, Versailles, 71-89. 
Darré J.-P., 1996. L'invention des pratiques dans l'agriculture : vulgarisation et production locale de connaissance. Éditions Karthala, Paris, 194 p.

Darré J.-P., 2006. La recherche co-active de solutions entre agents de développement et agriculteurs. Éditions Gret, Cnearc, Gerdal.

Dumrongrojwatthana, P., Trébuil G., 2011. Gaming and simulation for colearning and collective action; companion modelling for collaborative landscape management between herders and foresters in northern Thailand. In: Knowledge in action. The search for collaborative research for sustainable landscape development (van Paassen A. van den Berg J., Steingröver E., Werkman R., Pedroli B, eds), Wageningen Academic Publishers., Wageningen, The Netherlands, 191-219.

Etienne M. (ed.), 2014. Companion Modelling: A Participatory Approach to Support Sustainable Development. Springer \& Éditions Quæ. 319 p.

Ruault C., 1996. L'invention collective de l'action. Initiatives de groupes d'agriculteurs et développement local. Éditions de l'Harmattan, Paris, 240 p.

Ruault C., Lémery B., 2008. La mise en place de dispositifs de gestion concertée de la ressource en eau : questions de méthode. In: La gestion concertée des ressources naturelles. L'épreuve du temps (Méral P., Castellanet C., Lapeyre R., coord.), Karthala, Paris, 87-104.

Ruault C., Lémery B., 2009. Le conseil de groupe dans le développement agricole et local : pour quoi faire et comment faire ? In: Conseil et développement en agriculture : quelles nouvelles pratiques ? (Compagnone C., Auricoste C., Lémery B., coord.), Educagri and éditions Quæ, Dijon and Versailles, 71-96.

30In French, dispositif.

31Corporación de Estudios Educativos, Investigativos y Ambientales (CEAM ), Consejo Comunitario Mayor Asociación Campesina Integral de Atrato (COCOMACIA), peasant and indigenous organizations (Kichwua, Muruy y Siona) in Putumayo, WWF Colombia, Universities of British Columbia, Aalborg and Antioquia.

32Association member of the France Active national network, defining itself as a solidarity financier for employment in Languedoc-Roussillon (airdie.org/airdie ${ }^{\mathbb{Z}}$ ). 
33The ComMod collective (http://www.commod.org/ ${ }^{*}$ ), which was formalized into an association in 2009, originally began as a scientific network of researchers, especially in the social sciences, (agro)ecology and computer modelling, who designed, tested and evaluated this approach during the previous decade. This group offers training and methodological support to researchers and development agents interested in implementing this approach in territorial development processes.

34Gerdal (http://www.sad.inra.fr/Ressources/Developpement-et-action-locale-Le-Gerdal ־7) is an association founded by sociology researchers. Its mission is to provide an interface between research, development and training, with a view to developing methodological support for the production of knowledge by agricultural and rural actors involved in local development processes. 


\section{Evaluating the effects of innovations}

\section{Chapter 13}

\section{The abattoir, from the factory to the farm. Ethics and morality in the dynamics of innovation in agrifood systems}

\section{SÉbastien Mouret And Jocelyne Porcher}

Summary. The aim of this chapter is to clarify the place of morality in innovation processes. To generate responsible innovation(s), a category that is today key in innovation policies, we have to understand how moral responsibility, which is at the heart of agriculture and food issues, influences innovations. This assessment is undertaken here using a descriptive approach and lays particular stress on the actors' moral judgments. This chapter discusses the results of an action-research approach on alternatives to the industrial slaughter of livestock animals, showing how farmers place their moral responsibility for their animals at the centre of an innovation process: onfarm slaughter. More broadly, it invites us to restore the common-sense knowledge of morality in the face of a rise in ethical expertise, both in the evaluation of innovations and in the transformation of relationships with animals in our societies.

One of the pressing current challenges for agriculture and the food sector is to develop innovations that can be called responsible. If responsibility is central to European research funding programmes[35] and innovation policies[36], it is only because it is at the heart of developmental issues in Western industrialized societies. And yet, ethics and/or morality are poorly addressed in much of the research on innovation in agriculture and the food sector. 
The aim of this article is to show that morality not only regulates innovations but can also help generate them. The notion of moral responsibility is not just a mere part of the production of innovations, it can even be its most important rationale. The challenge here is to shed light on the place of morality in the innovative choices of actors and in innovation processes.

Innovation, in fact, is no longer sufficient in itself to legitimize the implementation of new technologies. When called upon to justify sociotechnical changes, arguments such as 'it is new, so it has to be better' or 'we do not stop progress', which would suggest that innovation, by itself, is virtuous and beneficial to all, are considered inadequate and inconsistent. The moral requirement arises from the recognition of the negative consequences of technology-based innovations, which are not ethically neutral because they have magnified the vulnerability of human beings and nature in a critical manner (Jonas, 1990).

On this point, in the livestock sector, an industrial and intensive form of relationships of work with livestock animals, and the technical and organizational innovations of recent decades are one of the causes of the degradation and destruction of environmental resources (pollution, greenhouse gas emissions, species extinction, etc.). In addition, innovations related to the industrialization of livestock farming activities cause suffering, not only to animals, but also to human beings at work (Porcher, 2002a, 2017b; Mouret, 2010, 2012a). Suffering at work is a moral issue: it results not only from the violence of working with animals and with nature, but also from the increase in disparities between farmers, and thus from the impoverishment of a growing proportion of them.

After a discussion on the distinction between ethics and morality, we will focus on the links between morality and innovation in the evolution of relationships with animals for food production. We will illustrate these links using an example of an innovation process based on morality, namely the action-research effort for innovation titled 'When the abattoir comes to the farm'.

\section{Ethics or morality?}


Do ethics and morality refer to the same concept? Should we differentiate between them? It is not easy to provide a clear answer to these questions. It is common to distinguish between these two notions by assigning morality a more normative or even universal meaning, referring to rights, rules, principles or maxims. Ethics, on the other hand, is more subjective and reflexive, and can refer to desires, interests, etc. This contrast reflects, in part, a key distinction in the social and human sciences between norms and values, although this distinction is sometimes challenged, for example, by situated ethics (Dewey, 2011). The sociology of ethics (Isambert et al., 1978) favours the notion of ethics over that of morality, not only to guard against the excesses of moralism, but also because ethics appears as a broader and dynamic notion, with morality designating, in contrast, rigid systems of norms attached to values. Nevertheless, the term 'ethics' also contains, in its common meaning, a deontological (or normative) dimension.

Applied ethics, a branch of moral philosophy, takes the form of a kind of science on morality concerning human and non-human affairs, which can sometimes include doctrinal characteristics. It is characterized by a set of distinct disciplinary fields (bioethics, animal ethics, environmental ethics, etc.) whose approaches are, for the most part, a priori normative. It can be assumed that the rise of applied ethics is, more broadly, part of the growing importance of ethics in Western societies, a symptom of a moralization of various fields of human activities. Based on the pretext that there would no longer be any - or at any rate not enough - morality in the organization of these activities, there has been a spurt in the establishment of ethics committees, ethical charters, ethical labels and guides to good practices for some years now in an effort to reintroduce moral rules in these activities. Agriculture and the food sector have not been immune to this process of moral rationalization.

There is therefore no reason, a priori, to maintain or underscore a distinction between those two terms. Their meanings tend to be merge and they can be used without differentiating between them (Canto-Sperber and Ogien 2004; Pharo, 2004).

In this chapter, however, we rely on the distinction proposed by Ricœur to understand the respective places of ethics and morality in the emergence of 
an innovative proposal, that of on-farm slaughter. For Ricœur (1990), ethics refers to an objective, both collective and individual, of a good and just life, i.e., 'a goal of a good life, with and for others, in just institutions'. Morality, on the other hand, is the 'articulation of this goal through norms characterized by both the claim to universality and a controlling effect' (Ricœur, 1990). Ethics is an intention, morality a praxis. Ricœur establishes a primacy of ethics over morality, but also the necessity for ethics to go through morality. From his point of view, 'morality is only a limited, though legitimate and even indispensable, implementation of the ethical goal, and ethics in this sense encompasses morality' (Ricœur, 1990). Ethics can therefore be seen as a project of society, a project of collective life, while morality represents the means to realize this project in terms of values qualified by the notions of good and bad, right and wrong.

\section{Morality and innovation}

One of the main debates on innovations in the agrifood sector, concerning controversial technological innovations such as genetically modified organisms, pertains to their ethical assessment (Reber, 2011). Ethical assessment aims to influence the instrumental rationality of innovations by restoring a moral rationality, so as to reduce their significant negative effects on the human or non-human environment. In other words, it aims to regulate work through morality (Habermas, 1990) and can therefore be seen as an instrument for the moralization of innovations (Chapter 2).

How to assess the 'good' or 'less risky' nature of technical innovations? To examine the issue of the ethical assessment of innovations is to be interested in the forms of judgments and value systems which participate in an innovation process, i.e. in the processes by which technical inventions become morally acceptable innovations. Assessment becomes more complex, both ethically and politically, the more inclusive it becomes. The inclusion of civil society actors in processes to assess innovations originates from a crisis of the right of science to manage innovations on its own, including assessing them ethically. It reflects a challenging of the hegemony of experts (Reber, 2011; Pellé and Reber, 2016) in innovations and in debates on ethics. For example, animal welfare standards in the agrifood sector, as also in 
biomedical research, have been largely defined on the basis of the influence of experts. Groups of researchers from various disciplinary backgrounds have been assigned the task of studying the moral problems posed by the use of livestock animals and those used in experimentation, and of proposing areas of reflection and action to public institutions in their decision-making.

It is necessary to consider the plurality of dimensions in moral judgments and the distinctions that can be made. Distinctions can be made, for example, between the moral judgment of the innovation process and that of the innovation itself. For example, a distinction of moral judgment can be made between, on the one hand, the use of genetically modified plants to gain knowledge on plant growth and, on the other, the cultivation of genetically modified organisms in the open field for production and consumption. However, it is also possible to paint both situations with same moral brush: whatever the goal and possible consequences of the innovation, it is already an evil in itself to manipulate living organisms.

If innovation has to pass the test of morality - which underscores the importance of moral assessment -, morality can also be a source of innovation. It can even be considered an essential source, according to suggestions emanating from discussions on environmental issues, which call for the development of 'green' technologies, based, for example, on the use of solar or wind energy to combat global warming. These technological innovations are, no doubt, also motivated by economic and political motives. But they still originate partially from moral rationality. This is what agrifood innovations based on fair trade also reveal, albeit in other ways (Ferrando Y Puig and Giamporcaro-Saunière, 2005; Le Velly, 2017). This type of trade was implemented in response to a growing awareness of social inequalities between consumers in industrialized countries and producers in developing countries. Solidarity is the ethico-social glue of the relationships of network of actors on which this innovation is based.

The transformation of the moral status of animals in our industrialized societies has led to an entire series (or cluster) of innovations that are part of production and service economies (Porcher, 2011 and 2017). These innovations are either inclusive or exclusive, depending on whether they help maintain animals within the agrifood sector or to exclude them from it. The 
first type increases the value assigned to the work of animals, offers new services (animals insurance, retirement, etc.), generates labelling (the consideration of animal welfare or ethics), reorganizes work (on-farm slaughter) or changes the very nature of animal contributions (animal-assisted therapy or zootherapy). The second type, on the other hand, follows the logic of substituting animals and products of animal origin by artefacts and substitutes (robots or 'augmented' humans, food substitutes or in vitro meat production).

Innovations of substitution are emerging in the context of controversies surrounding animal foodstuffs, in which moral responsibility for animals and, more broadly, for nature acquires centre stage. Substitution takes the form of a process of increasing human independence from livestock animals, an independence that will require major agrifood innovations. The production of plant milk, imitation meat, vegetarian food supplements (for example, spirulina) and the growth of bio-vegan agricultural systems (agriculture without livestock) are part of a process of transforming agriculture and the food sector towards an all-vegetarian diet, in which the animal no longer has a place. The substitution of animal proteins by plant proteins is seen as a remedy for the violence and the suffering experienced by livestock animals. Furthermore, research on entomophagy (production and consumption of insects) and on in vitro meat (culture of muscle cells extracted from live animals) aims to substitute the production and consumption of animal proteins by those that are 'suffering-free'. These innovations of substitution are not only a consequence of criticism from animal welfare movements against using animals for human consumption, but also from the adaptive strategies of economic actors in the agrifood industrial sectors. In other words, this type of substitution has at least as much to do with capitalism as with veganism (Porcher, 2013; Porcher, forthcoming).

After this brief discussion on these food innovations to exclude animals from our diet, we will focus in particular on an inclusive innovation and will show, via an example of an action-research innovation concerning on-farm slaughter, how moral responsibility for animals is at the heart of an innovation approach for sustainable livestock farming. This requires, as a first step, a quick look at some key elements of the process of industrialization of livestock farming. 


\section{When the abattoir comes to the farm: an action- research effort for innovation based on moral values}

The manner in which abattoirs, both large and small, are currently being operated is being called into question by numerous livestock farmers due to their opacity and potential or actual violence against animals. The farmers' misgivings over these abattoirs' functioning are a source of moral suffering for them, especially for those who participate in direct sales or short supply chains and claim to be traditional farmers (Porcher et al., 2014). A growing number of them, with the informed support of their customers, therefore choose to slaughter their animals on the farm, albeit illegally, risking six months in prison, a fine of 15,000 euros, and the loss of agricultural aid, among other sanctions.

The anchoring of the relationship of work between livestock farmers and animals, and more broadly that of our domestic relations with animals, in the triptych of the gift according to Mauss (2016) - to give - to receive - to return -, helps explain this transgression of regulations. Raising animals is not just about producing them on the basis of technical and economic efficiency. It is also, and above all, the living together of human beings and animals. The moral rationality of the relationship of work in livestock farming is based on a gift of a 'good life' (to use Ricœur's expression) to animals. This gift is as much an act of the legitimization of their slaughter for the purposes of food (Porcher, 2002b) as it is a gesture of gratitude towards them, for the life they give to human beings, since 'to feed oneself is to live' (Mouret, 2012b). It is in the framework of these relationships of gift-giving that the death of animals acquires meaning, and that the criticism of abattoirs by livestock farmers can be understood.

\section{Give a good life, give a good death}

The gift of a good life forms part of a moral outlook of livestock famers towards their animals, which does not end at the gates of the abattoir. The ethical intention of the farmers who circumvent the regulatory requirement of 
taking their animals to the abattoir is also to give them a good death. Death represents the end, not the goal, of their relationship of work with animals and their investment in giving them a good life. The death of animals can only be considered good if their life has been as good as possible, and the slaughter takes place under conditions that accord them respect. And yet, the abattoir, because of its predominantly industrial character, is incapable of giving them this good death. Since the ethical aim of giving a good death is a priority for these breeders, they adopt various practices (slaughtering in situ, in a dedicated room; slaughter in the meadow; purchase of ad hoc equipment, such as a stun gun, over the internet) that contravene legislation in force, but which they consider appropriate and necessary at a moral level, given the absence of other alternatives more conducive to the fulfilling of their aim of giving a good death.

To give a good death is therefore to make moral choices. It is, first of all, to assume responsibility for the killing, i.e. to choose not to abandon one's animals. This does not necessarily mean that livestock farmers have to slaughter their animals themselves, but creating conditions that allow them to take responsibility for it. Giving a good death also means preventing any suffering to animals, be it related to the practical accomplishment of technical acts such as stunning and bleeding, or be it due, before their transition from life to death, to the removal of the animals from their social environment of belonging, namely their herd. This is why slaughter in the meadow, sheep pen or barn, amongst other animals, is considered a good practice. To give a good death is also to give death for good reasons. This is why the waste that is left over at the abattoir, of a substantial part of the carcasses, is considered immoral. The animal must not die for nothing. This means that the carcass must be utilized from head to hoof. A farmer phrases it thus: 'We do not waste, it has cost a life.'

\section{Innovating to respond a moral issue}

How to encourage innovations in the slaughter of animals based on the moral issues raised by the relationship between human beings and animals? How to generate an innovation process that aims to legalize practices which, while being based on moral values, are considered illegal today? 
In 2005, following surveys of livestock farmers and abattoir workers which highlighted the importance of moral issues in the abattoir problem, an article was published proposing a slaughter truck concept, developed with the help of a student designer (Porcher and Daru, 2005). The results of the surveys showed, on the one hand, the regret expressed by abattoir workers of doing a bad job not only in the treatment of animals but also in the processing of meat ('hastily done, badly done') and, on the other, the underlying resistance of farmers to delegate the slaughter of their animals to abattoirs that show scant respect for animals. This proposal in 2005 was apparently premature, and its author was requested by the French government's Directorate General for Food to stop promoting such tools, given that they were prohibited by the regulations in force.

Almost ten years later, in 2013, following new results of surveys of livestock farmers, especially of those involved in direct sales and short supply chains, which showed the continued reluctance of farmers in using abattoirs, and even its crystallization in more assertive rejections, we organized collective surveys of livestock farmers. These surveys led to the publication of a book (Porcher et al., 2014) presenting not only a critical summary of abattoirs but also alternative proposals from livestock farmers, such as on-farm slaughter using a mobile abattoir, or the revival of smaller and local abattoirs. Given that the obstacles to the implementation of these alternatives were regulatory in nature, we sent the book to a hundred members of the French parliament and the French senate concerned by agricultural issues. Our mails went unanswered. In 2014 too, our proposals for an innovation mechanism regarding the slaughter of animals remained a non-starter.

In 2015, following our investigations and efforts for mobilization, the Federation of Associations for Agricultural and Rural Employment (Fadear) presented a Casdar[37] project, which was rejected. It was presented again in 2016, only to be rejected again, despite a context of critical media coverage of abattoirs.

We then decided to undertake an action-research effort for innovation[38], on the margins of what is now called 'living labs'. To innovate in this area of slaughter of animals and to convince public authorities, the moral concerns of livestock farmers alone were clearly insufficient and it became necessary to 
buttress them with those of other actors, such as consumers, animal protection groups, veterinarians, butchers, etc., and to use other avenues than books or submissions of research and development projects. This actionresearch effort for innovation assumed the form of a collective, and thence of an association called 'When the abattoir comes to the farm'[39], and was disseminated through a website and a Facebook page[40]. This association includes livestock farmers and their collectives, researchers, animal protection groups, consumer associations (BioWhere, Nature et Progrès, Demeter), veterinarians (affiliated to 'Groupement d'interventions et d'entraide Zone verte' as well as independent veterinarians), butchers, journalists, filmmakers, and other citizens. In addition, nearly 1300 people[41] have voiced their support for this collective through the internet.[42] The main objective of this action-research effort for innovation is to remove the regulatory barriers that prevent livestock farmers interested in experimenting, on their own, with equipment for the on-farm slaughter of animals. While our effort was slowly growing in the public domain, the impact in the media of videos denouncing livestock farming, made and widely distributed by abolitionist associations, gave a huge fillip to our own effort, and made it possible to contrast the moral injunctions of activists advocating the wholesale abolition of livestock farming with more complex and nuanced lines of thought.

The media buzz around these videos led to the setting up of a Parliamentary Commission on abattoirs. As representatives of a collective offering a major innovation in livestock farming, we were successful in being heard by this commission[43] and in showing the link between the implicit moral positions of the livestock farmers, their deontology and their slaughtering practices which, while illegal, were moral from their point of view. We were also able to show that there are viable alternatives to current slaughtering methods.

\section{To innovate, one has to undertake an exercise of criticism}

For livestock farmers, engaging in an illegal process of innovation constitutes an act of civil disobedience (Ogien and Laugier, 2011). The transgression of the regulations governing the slaughter of livestock animals reflects a refusal 
by farmers, expressed non-violently, collectively and publicly, to comply with the law, because they consider it shameful and illegitimate and because it does not allow them to meet the ethical goal inherent to their relationship of work with animals.

This opposition to the law is characterized by a profound asymmetry in the actors' positions in this balance of power which opposes, on the one hand, a collective that is the proponent of an innovative proposal - on-farm slaughter - and, on the other, the legislative apparatus in charge of regulating the slaughter of livestock animals. This asymmetry reveals, a contrario, the power of the moral commitments of the livestock farmers with respect to their animals. Because this moral commitment comes at a price; it constitutes a legal and economic risk. These farmers have everything to lose, except their dignity. Because what is legal is the industrial model, as reminded to Stéphane Dinard by a member of the French parliament, during its 'abattoirs' hearings: 'We are in parliament, where laws are made. And yet, you have just told us that you work in an illegal manner, and you question those who work in a legal manner, according to another model, albeit industrial, but one that society agreed to at a given point in time.'[44] To which Stéphane Dinard answered simply, 'We must change the law.'

The action-research mechanism for innovation through which this innovation process takes place has also the aim of sharing the livestock farmers' existential predicaments with a wider public (Boltanski, 2009). These predicaments are marked by their painful experiences when they are confronted by the impossibility of giving a good death to their animals, or even of continuing in their profession. The action-research effort for innovation has not only helped formulate these painful experiences using the theme of ethical suffering at work (Dejours, 1998), but also helped consolidate these actors' desire for change, thus providing visibility to what had been scattered and invisible. The collective thus formed serves as support for livestock farmers to engage in a critical action and be more effective proponents of on-farm slaughter.

For the researchers, it is a matter of framing the moral questioning of the livestock farmers and of the other actors involved into a research topic on the dynamics of innovation generated by moral issues. But this questioning, 
outside the normal framework of accepted dominant systems, is tainted and alleged to be unscientific.

From our point of view, any innovation concerning the slaughter of animals that satisfies the ethical desire of the livestock farmers who wish to regain control over their work will entail an act of disobedience. Disobedience of the law, disobedience of the axiological and political neutrality expected from research. It is worth remembering that if the law was respected at all times and by everyone, nothing would ever change. It is because there are, at a given moment, people who disobey the law and highlight its faults that the law can change. This applies not only to the law in its legal sense, but also to rules based on an implicit consensus and applied in a profession.

\section{Responsible innovation and research}

The action-research effort for innovation concerning on-farm slaughter, as presented in this article, can be considered responsible research and innovation. Moral responsibility is at the very heart of this innovation mechanism. The latter takes different forms. For livestock farmers and for other actors of the collective (researchers, consumers, animal protection activists, veterinarians, etc.), it is not only a question of answering the 'call' of animals, which suffer due to industrial slaughter, but also to answer for the life and death of these animals, to whom they feel morally obligated. For an increasing number of citizens, eating meat is becoming a moral predicament (Neron de Surgy and Porcher, 2017), with the suffering of animals and their slaughter forming its two nubs.

On the other hand, the criticism this action-research mechanism has given rise to contrasts with the criticism of the relationship between human beings and animals by animal rights groups, which permeates the contemporary debate on what is commonly called the 'animal question'. Which natural beings should our moral responsibility favour? How to be morally responsible with respect to them? The answer to these questions is essentially based on science, against a backdrop of moralism (Hache and Latour, 2009). Philosophers and legal experts are entrusted with the task, assuming they have not already grabbed and appropriated it as their own, to decide the 
moral value of non-human organisms, and thus define the perimeter of our moral responsibility and its internal variations. The influence of animal ethics (Jeangène Vilmer, 2008) in the debate on the animal question testifies to this apportionment of facts and values. The a priori normative approaches of this discipline - and more broadly the approaches of animal studies - are disconnected from the moral reality of the relationships between human beings and animals, and consequently of the relationship of work between livestock farmers and their animals.

Because of its inclusiveness, the action-research mechanism for innovation that we have discussed here helps restore common sense knowledge about morality and, consequently, influences moralism. The inclusion of livestock farmers lends weight and importance to the manner in which laypersons address the question of good and bad, right and wrong, regarding the life and death of animals. The action-research mechanism for innovation transforms the conditions, both social and political, of exercising their critical sense, and therefore of their moral sense.

\section{Conclusion}

Taking ethics and morality into consideration in the dynamics of agricultural innovation and in the assessment of their properties is necessary because, explicitly or inexplicitly, researchers and actors of the agricultural world are, like all other actors, often driven by moral forces (Mauss, 2016). And yet, in agriculture, moral motives, as well as emotional ones, are neither obvious, nor evident. That is why they often stay unnoticed. Ethics and morality, however, are not areas reserved for the experts in ethics; on the contrary, one might even say, they are too important to remain solely their concern. To live, to work is to philosophize. What is amply demonstrated by the 'When the abattoir comes to the farm' action-research effort for innovation is that philosophizing, even though the experts may be loathe to admit it, is much better done as a shared activity. And it is in this bottom-up process that we should reconsider the place of ethics and morality in agricultural innovations. Furthermore, this chapter shows that instead of starting from an a priori definition of the concept of responsible innovation, which is the approach currently used in assessing innovations, we should start from the concept of 
moral responsibility and, more broadly, of morality, as it unfolds in the course of social life. Only then we will be able to understand, in association with a sociological approach, its role in innovation processes as illustrated by the action-research effort for innovation.

\section{Bibliography}

Boltanski L., 2009. De la critique. Précis de sociologie de l'émancipation. Gallimard.

Canto-Sperber M., Ogien R., 2004. La philosophie morale. Presses Universitaires de France, Paris.

Dejours C., 1998. Souffrance en France. La banalisation de l'injustice sociale. Seuil, Paris.

Dewey J., 2011. La formation des valeurs. La Découverte, Paris.

Ferrando Y Puig J., Giamporcaro-Saunière S., 2005. Pour une " autre " consommation. Sens et émergence d'une consommation politique. L'Harmattan, Paris.

Habermas J., 1990. La technique et la science comme idéologie. Gallimard, Paris.

Hache E., Latour B, 2009. Morale ou moralisme ? Un exercice de sensibilisation. Raisons politiques, 2(34), 143-165.

Isambert F-A., Ladrière P., Terrenoire J-P., 1978. Pour une sociologie de l'éthique. Revue française de sociologie, 19(3), 323-339.

Jeangène Vilmer J-B., 2008. Éthique animale. Presses Universitaires de France, Paris.

Jonas H., 1990. Le principe de responsabilité : une éthique pour la civilisation technologique. Champs Flammarion. 
Le Velly R., 2017. Sociologie des systèmes alimentaires alternatifs. Une promesse de différence. Presses des Mines, Paris.

Mauss M., 2016. The Gift. University of Chicago Press. (Translation of 'Essai sur le don' (2007/1923), Presses Universitaires de France, Paris.)

Mouret S., 2010. Détruire les animaux inutiles à la production : une activité centrale du point de vue de la souffrance éthique des salariés en production porcine industrielle. Travailler, 24(2), 73-91.

Mouret S., 2012a. Élever et tuer des animaux. Presses Universitaires de France.

Mouret S., 2012b. La valeur morale d'un animal. Esquisse d'un tableau en forme de dons de vie et de mort. Le cas des activités d'élevage. Revue du Mauss, 39, 465-486.

Neron de Surgy O., Porcher J., 2017. Encore carnivores demain? Quand manger de la viande pose question au quotidien. Éditions Quæ, Versailles.

Ogien A., Laugier S., 2011. Pourquoi désobéir en démocratie? La Découverte.

Pellé S., Reber B., 2016. Éthique de la recherche et innovation responsable. Iste Éditions.

Pharo P., 2004. Morale et sociologie. Le sens et les valeurs entre nature et culture. Gallimard.

Porcher J. (coord.), 2017a. Travail animal, l'autre champ du social. Écologie et politique, 54, Éditions Le Bord de l'eau.

Porcher J., 2017b. The ethics of animal labor. A collaborative utopia. Palgrave Macmillan.

Porcher J., 2002a. Éleveurs et animaux, réinventer le lien. Presses Universitaires de France, Paris.

Porcher J., 2002b. L'esprit du don, archaïsme ou modernité de l'élevage : 
éléments pour une réflexion sur la place des animaux d'élevage dans le lien social. Revue du Mauss, 20, 245-262, <http://www.cairn.info/revue-du-

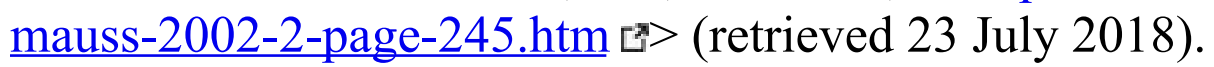

Porcher J., 2011/2014. Vivre avec les animaux, une utopie pour le XXI ${ }^{e}$ siècle. La Découverte, Paris.

Porcher J., 2013. Ce que les animaux domestiques nous donnent en nature. Revue du Mauss, 2(42), 49-62.

Porcher J., forthcoming. Cause animale, cause du capital. Éditions Le Bord de l'eau.

Porcher J., Daru E., 2005. Concevoir des alternatives à l'organisation industrielle du travail en élevage. Un camion pour le transport et l'abattage des animaux. Inra-Sad, FaçSade, 23.

Porcher J., Lecrivain E., Savalois N., Mouret S., 2014. Livre blanc pour une mort digne des animaux. Éditions du Palais.

Reber B., 2011. La démocratie génétiquement modifiée. Sociologies éthiques de l'évaluation des technologies controversées. Presses de l'Université de Laval.

Ricœur P., 1990. Soi-même comme un autre. Seuil.

Von Schomberg R., 2011. Towards Responsible Research and Innovation in the Information and Communication Technologies and Security Technologies Fields. European Commission, Brussels, 217 p.

\section{Chapter 14}

\section{Evaluating the impacts of agricultural}




\section{innovations}

\section{Agathe Devaux-Spatarakis and Sylvain QuiédeVille}

Summary. Since the 2000s, researchers engaged in innovation processes are having to respond to the demand of donors, national research and development agencies and civil society that their research should be open to evaluation. In order to meet this demand, agricultural researchers have to use tools and methods to help them determine the effects of their proposals, not only at agronomic level, but also on the economic, social and environmental dimensions. This chapter presents the different evaluation methods that can be used, as well as the trade-offs to be made in order to choose the approach that is most appropriate for the innovation under study and for issues raised by the evaluation. Two case studies on the use of methods to evaluate the impact of research, conducted as part of the ImpresS and Impresa projects, are presented and discussed.

Since the beginning of the 20th century, many studies conducted by researchers in the field of agriculture have included rigorous evaluations of the impacts of innovations they propose (Fisher, 1926). These evaluations have focused almost exclusively on the innovations' agricultural impacts, but researchers today have to use evaluation methods that can also predict the social, cultural and economic impacts of their innovations. Since the beginning of the $2000 \mathrm{~s}$, donors, international organizations, and national research and development agencies have expressed their preference to fund innovations that have been partially proven on the field, i.e. evaluated positively as to their initial agricultural and social impacts (Naudet and Delarue, 2007; Evaluation Gap Working Group, 2006).

This new evaluative imperative is compelling agricultural researchers to adopt evaluation methodologies that conform to international standards, and which are similar to methods used in the evaluation of public programmes and projects. As a result, there is a shift from a scientific evaluation of a project's agricultural effects towards an evaluation as defined by the Organization for Economic Co-operation and Development (OECD, 2002), 'The systematic and objective assessment of an on-going or completed project, programme or policy, its design, implementation and results. The aim is to determine the relevance and fulfilment of objectives, development 
efficiency, effectiveness, impact and sustainability.'

Even though agricultural research is backed by a substantial body of programme-evaluation methodologies (Shadish et al., 1991; Weiss 1972; Patton, 2001), the application of impact assessment methods to sometimes complex innovation processes raises specific methodological challenges. Consequently, several agricultural research institutes, in France and elsewhere in Europe, have undertaken research projects for developing adapted evaluation approaches. Three such projects are: Analysing the Impacts of Public Agricultural Research (Asirpa), undertaken by the French National Institute for Agricultural Research (INRA); Impact of Research in the Countries of the South (ImpresS), undertaken by the French Agricultural Research Centre for International Development (CIRAD); and the European project Impact of Research on EU Agriculture (Impresa) which brings together several institutes, including the Research Institute of Organic Agriculture (FiBL)[45]. These initiatives have the common challenge of developing approaches, tools and mechanisms capable of understanding and determining the impacts of these innovation processes on society.

This chapter first presents the evaluation methods, tools and instruments used in areas other than agricultural research, but which can be useful for it. Then we compare two innovation evaluation approaches studied in the ImpresS and Impresa research projects. Finally, we will discuss the takeaways from these two experiences.

\section{How to choose an evaluation method?}

In order to understand the issues surrounding a methodology to evaluate innovation impacts, we must first present the range of evaluation methods and the issues that each one of them raises.

\section{Evaluation: a range of practices}

'Evaluation - more than any science - is what people say it is; and people currently are saying it is many different things' (Shadish et al., 1991). This 
definition from American academics testifies to the difficulty of understanding evaluation, a difficulty explained by the multiplicity of reasons for using evaluation, by the varying degree of openness to different actors in the evaluation, as well as by the diverse uses of its results.

\section{Why evaluate?}

A first objective that justifies evaluation is to produce information relevant to planning a project or a process. This type of evaluation is conducted ex ante, i.e. before the intervention. This involves estimating the impacts of a future intervention, of building scenarios that will help choose between different options and of anticipating the potential risks in the intervention's implementation so that it can be appropriately fine-tuned. It also involves understanding the mechanisms through which the intervention can produce the intended impacts.

A second objective is to identify areas for improvement for future interventions. This concerns the generation of knowledge about the intervention's processes and mechanisms that hinder or enable its smooth conduct and the production of impacts. This type of ex post evaluation can be carried out after the intervention mechanism has been implemented, with a view to fine-tuning and improving future interventions. It can also be conducted in itinere, i.e. during its implementation, in order to evaluate the achievement of the initial intermediary effects, identify the strengths and weaknesses of the intervention, and make the necessary adjustments as soon as possible. This type of evaluative approach requires the resources and capability to comprehend the causal mechanisms involved. Unlike a monitoring mechanism, which can also be set up during the intervention, the evaluation not only examines the logic and the relevance of the assumptions guiding the intervention, but also the way in which it fits into its environment.

The third objective is accountability, i.e. the need or requirement to be accountable for the action undertaken as part of the intervention, with regard to the expectations of the entity that commissioned the evaluation. We can 
investigate the efficiency of the action (measured by the ratio between the results obtained and resources expended), its usefulness (does it meet the needs of the beneficiaries?), its effectiveness (are the objectives attained?), as also its coherence (link with other mechanisms) or its relevance (is this the best solution to solve the problem identified at the outset?). Of course, the answers to these questions can also be responses to the second objective presented above. The diagram below (Figure 14.1) presents these different evaluation criteria and the dimensions concerned.

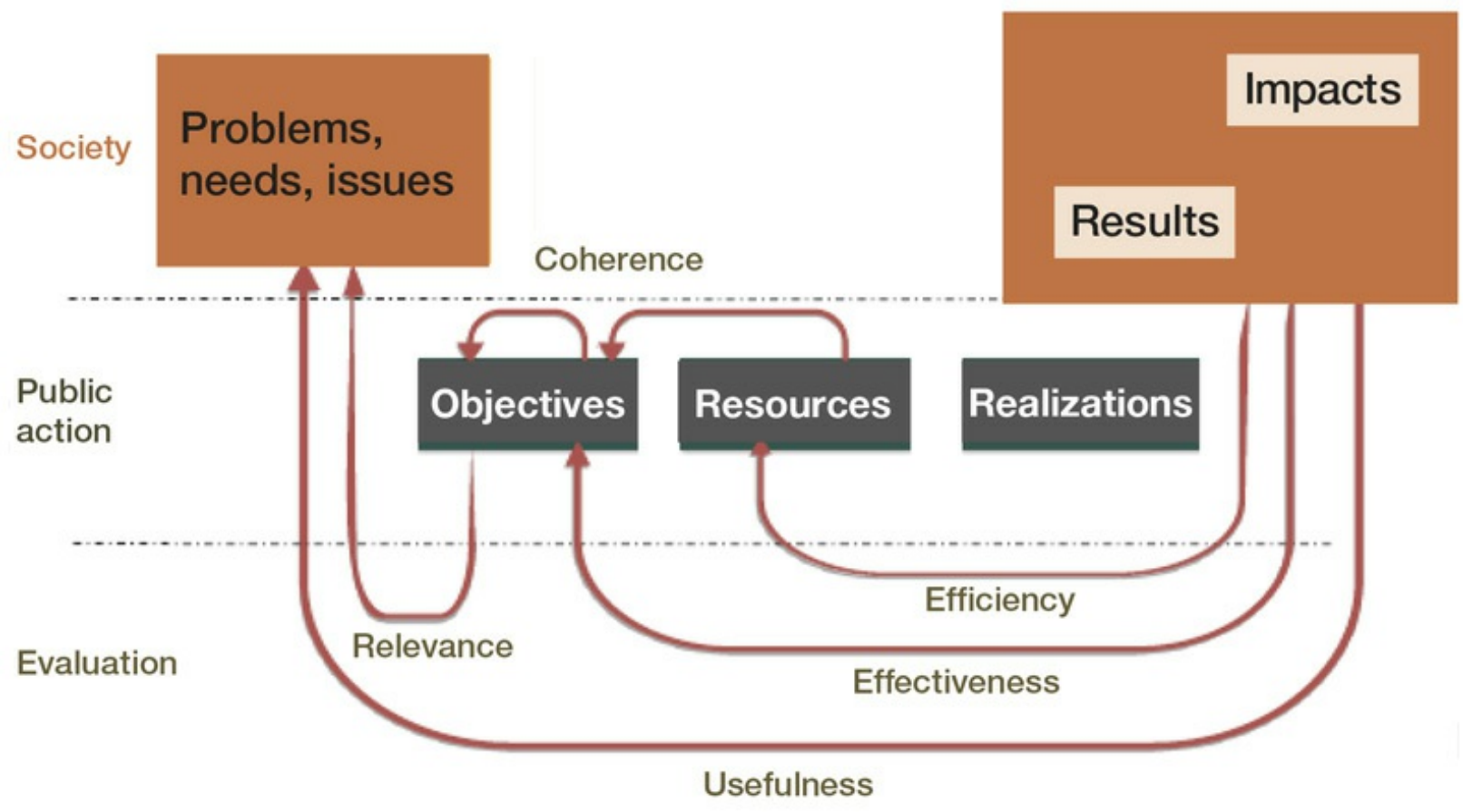

Figure 14.1. Evaluation criteria and dimensions concerned (source: Quadrant-Conseil).

For example, when an evaluation question is meant to determine the production of results in terms of resources, it becomes part of the efficiency criterion.

The same evaluation can meet several of these objectives. Thus, a resultsoriented evaluation may also seek to understand the nature of the processes that influence the course of the action in order to make adjustments to it. It is also possible for the same intervention to provide for three evaluation periods: first, estimating the impacts a priori, then undertaking a mid-point evaluation in order to correct the implementation and finally comparing the final results to those expected through an a posteriori evaluation. 


\section{Evaluation, for whom and by whom?}

Evaluation methods can also be distinguished on the basis of the different kinds of actors participating in them. An evaluation can be conducted either by a person belonging to the institutions implementing the intervention that is being evaluated, or by external persons. External evaluators are usually preferred for result-oriented evaluations, whereas internal evaluators (usually better placed to identify intervention issues) are favoured for learningoriented evaluations (Conley-Tyler, 2005).

The team responsible for conducting the evaluation can also involve other actors in the process, such as funders, supervisory bodies, field workers, direct or indirect beneficiaries of the intervention, or even other citizens. There can be several degrees of participation characterized by the 'breadth' of the evaluation (representing the diversity of actors) (Table 14.1) and its 'depth' (representing the role played by each actor in the evaluation) (Baron and Monnier, 2003).

Table 14.1. The five levels of 'breadth' of participation in an intervention's evaluation.

\begin{tabular}{|l|l|}
\hline $\begin{array}{l}\text { 'Breadth' } \\
\text { of the } \\
\text { evaluation }\end{array}$ & Evaluation participants \\
\hline Level 1 & $\begin{array}{l}\text { Those who commissioned the intervention that is being evaluated and its } \\
\text { main operators (for example, donors and researchers) }\end{array}$ \\
\hline Level 2 & $\begin{array}{l}\text { Level 1 participants + those actually implementing the intervention (for } \\
\text { example, research partners and technicians) }\end{array}$ \\
\hline Level 3 & $\begin{array}{l}\text { Level 2 participants + direct beneficiaries (for example, agricultural } \\
\text { producers experimenting with or trying out the innovation) }\end{array}$ \\
\hline Level 4 & $\begin{array}{l}\text { Level 3 participants + indirect or potential beneficiaries (for example, } \\
\text { producers located in the same area as the experimenters, and potentially } \\
\text { impacted by the intervention) }\end{array}$ \\
\hline Level 5 & Level 4 participants + members of civil society or their representatives \\
\hline
\end{tabular}

The evaluation is said to be managerial, or co-produced, when the breadth of participation remains at level 1 or 2 . It can be seen as participatory when the breadth reaches level 3, with direct beneficiaries starting to participate in the 
evaluation activities. However, it is necessary to distinguish simple consultation from actual participation. The fact of taking the opinion of actors into account when collecting data, through interviews or questionnaires, does not constitute a participatory dimension per se. For evaluation to be truly participatory, the concerned actors must contribute directly to one or more evaluation activities.

Baron and Monnier (2003) identified the following evaluation activities:

- defining evaluation issues and questions;

- validating the evaluation method;

- managing the evaluation work;

- analysing and interpreting the evaluation data;

- formulating recommendations based on evaluation results.

Depending on the requirements, the evaluation team decides on the 'depth' of the participation; it may choose to assign different evaluation activities to different groups of actors. In order to encourage the appropriation of the evaluation results, it is advisable to include the actors who will be their future users. They must at least be part of the bodies managing the evaluation, or even participate in defining the evaluation's questions and scope (Patton, 1997). It is only when actors of level 3, 4, or 5 (Table 14.1) are involved in defining evaluation questions or issues, as well as in all of the evaluation's tasks, that we can speak of an empowerment evaluation (Fetterman et al., 2015).

The issues presented above are common to all evaluation procedures. We now present those that are specific to the evaluation of the innovations' impacts of.

\section{The specificities of evaluating the impacts of innovations}

On the one hand, the evaluation of impacts consists of assessing qualitatively or quantitatively the long-term changes resulting from the innovation. On the other, it can confirm that these changes are attributable to the innovation and not to other causes. The effects of the innovation may be positive or negative, 
direct or indirect, expected or unexpected.

Consequently, an evaluation of impacts requires the use of methods to analyse the relationships between the innovation and the observed effects. Two approaches are suitable for this purpose: first, an attribution analysis, comparing the results of the innovation to a counterfactual scenario and, second, a contribution analysis, which breaks down the innovation process into different stages, and then verifies and clarifies the causal links from each of these stages to the observed changes.

\section{Methods to demonstrate impacts using a counterfactual scenario}

These evaluation methods use a demonstration protocol based on the comparison of two situations, one with the innovation and the other without. Such an approach is known as an attribution analysis. The methodological challenge is to ensure the two groups are as similar as possible, consisting of units that we want to observe (for example, individuals), which are used for comparison, so that they are only differentiated by the innovation's presence or absence. The counterfactual scenario, i.e. the situation without the innovative intervention, is then comparable to what would have been the situation of the group being evaluated should it not have participated in the innovation.

The counterfactual group can be reconstituted by the evaluation team in a quasi-experimental manner, using statistical methods such as matching methods for internal or external comparison groups or the double difference method. It can also be reconstructed through modelling, to obtain a modelled counterfactual situation (SFE, 2011). Comparison groups can also be randomly constituted from among the potential beneficiaries of an innovation to be implemented, some of whom are included in a test group which will actually be affected by the innovation, with the others being included in a control group, which will not be affected and will serve as a counterfactual group, as part of a random assignment experiment (Duflo, 2005). 
This type of demonstration is adapted to simple innovations whose dissemination is based on the technology transfer model. It requires the innovation to remain stable over time and also not need major adaptations when implemented by actors on the field (Devaux-Spatarakis, 2014a). These innovations may be termed 'tunnel-type' programmes, in the sense that they follow a simple linear causality, and are little affected by the intervention of the actors (Naudet et al., 2012).

\section{Methods to demonstrate causality through a contribution analysis}

This second approach is based on the breaking down of the innovation process and an analysis of the different causal links involved. This is a contribution analysis (Mayne, 2001). It theorizes the link, not between an effect and a single cause, but between an effect and a set of causes, each of which cannot alone cause the final effect, but whose synergy with the other causes is likely to create the effect in question (Befani, 2012). In fact, the innovation being evaluated is only one contribution, among others, to the observed change. The challenge of the evaluation is to quantify the extent to which the innovation has contributed to the observed changes and to describe the manner in which it has done so.

Such an assessment is part of the 'theory-driven' family of methods. This approach breaks down the innovation into a succession of hypotheses on the changes it should engender among the various actors, hypotheses that are examined during data collection for the evaluation (Devaux-Spatarakis, 2014b). This key analysis tool can be called the theory of change, the logical impact diagram or the impact pathway (Douthwaite et al., 2003). It helps explain and provide information not only on the innovation, but also on its interaction with different actors and the influence the context has on it.

This approach is adaptable enough to be used for evaluating the impact of complex innovations, whose deployment is accompanied by evolutionary processes, especially as a result of the actors' involvement. It shows the various hypotheses underlying the innovative intervention and identifies the 
critical points pertaining to the interactions between the various actors participating in the innovation.

There is therefore no standard evaluation method. The evaluation's objectives, the role that one wants to assign to the different actors and the type of innovation process under study has to be ascertained before the general approach and the associated tools can be chosen for the evaluation (Table 14.2).

Table 14.2. Choice of impact evaluation approaches depending on the type of innovation to be evaluated.

\begin{tabular}{|l|l|l|}
\hline $\begin{array}{l}\text { Characteristics of the } \\
\text { innovation and } \\
\text { adapted evaluation } \\
\text { approaches }\end{array}$ & $\begin{array}{l}\text { Simple innovation or } \\
\text { technology transfer }\end{array}$ & Complex innovation system \\
\hline Innovation process & $\begin{array}{l}\text { New technology, practice or } \\
\text { standard, whose } \\
\text { implementation is controlled } \\
\text { by the initiators }\end{array}$ & $\begin{array}{l}\text { Technology, practice or } \\
\text { standard constantly subject to } \\
\text { adaptations by the actors who } \\
\text { adopt it }\end{array}$ \\
\hline Innovation actors & $\begin{array}{l}\text { Defined in advance and } \\
\text { monitored throughout the } \\
\text { implementation }\end{array}$ & $\begin{array}{l}\text { Evolving during the } \\
\text { innovation's implementation }\end{array}$ \\
\hline Innovation goals & Defined in advance & $\begin{array}{l}\text { Can be redefined as and when } \\
\text { required during the } \\
\text { innovation's adaptations }\end{array}$ \\
\hline Evaluation approaches & $\begin{array}{l}\text { Experimental or quasi- } \\
\text { experimental methods }\end{array}$ & $\begin{array}{l}\text { Approaches based on the } \\
\text { theory of change (impact } \\
\text { pathway) }\end{array}$ \\
\hline $\begin{array}{l}\text { Method of } \\
\text { demonstrating causality }\end{array}$ & Attribution analysis & Contribution analysis \\
\hline
\end{tabular}

\section{- An evaluation approach for complex innovations}

The contribution analysis approach for the evaluation of complex innovations is illustrated by two case studies concerning agronomic research from the ImpresS and Impresa projects. A comparison of the approaches used in these 
two cases will help draw conclusions on the methods, tools and instruments for evaluating the impact of agricultural research.

The ImpresS project[46] (Impact of research in countries of the South), led by the French Agricultural Research Centre for International Development (CIRAD), aims to develop and implement an impact evaluation approach to promote an impact-oriented culture within this institution. This involves, on the one hand, determining the impacts of innovations supported by CIRAD and its partners in the countries of the Global South and, on the other, to produce knowledge on the role of the research community in these innovative processes in order to help improve interventions. Thirteen case studies, spanning a range of innovations, were carried out in 2015 and 2016.

We will briefly present here one of these innovations, concerning the implementation of the 'Vales da Uva, Goethe' geographical indication for wine produced from the Goethe grape in the state of Santa Catarina, in southern Brazil, from 2004 to 2014[47], starting from the preparation of the dossier to apply for the recognition of the geographical indication, up until the marketing of wine under this appellation.

The Impresa project[48] follows the same type of approach, but with a few differences. The project's general aim is to measure, evaluate and understand the impacts of all types of European agricultural research activities. Part of the project involved the study of the complex causalities of the impact pathway starting from the research activities to the development of agricultural innovations, and then to the effects on society. We illustrate this approach using the example of the transition to organic rice systems, as part of a research programme for the deployment of organic farming in Camargue, France, initiated in 2000 by the French National Institute of Agricultural Research (INRA) and its partners. It was a matter of addressing the dilemma between, on the one hand, the need to produce rice to desalinate the soil and thus help sustain agricultural activity in the territory and, on the other, the obligation to reduce the environmental impacts of rice production.

These evaluations relied on a participatory approach and brought together the innovation's direct and indirect beneficiaries (i.e., levels 3 and 4, respectively, in the 'breadth' of participation, as defined in Table 14.1). 


\section{Recreating the impact pathway of the innovation in a participatory manner}

These two evaluation approaches used a causal analysis, by way of a reconstruction of the impact pathway, starting from the intervention of the research community to the impacts on the innovation process and, subsequently, on the beneficiaries and on society. The impact pathway is represented graphically in Figure 14.2 and shows the causal process of the innovation.

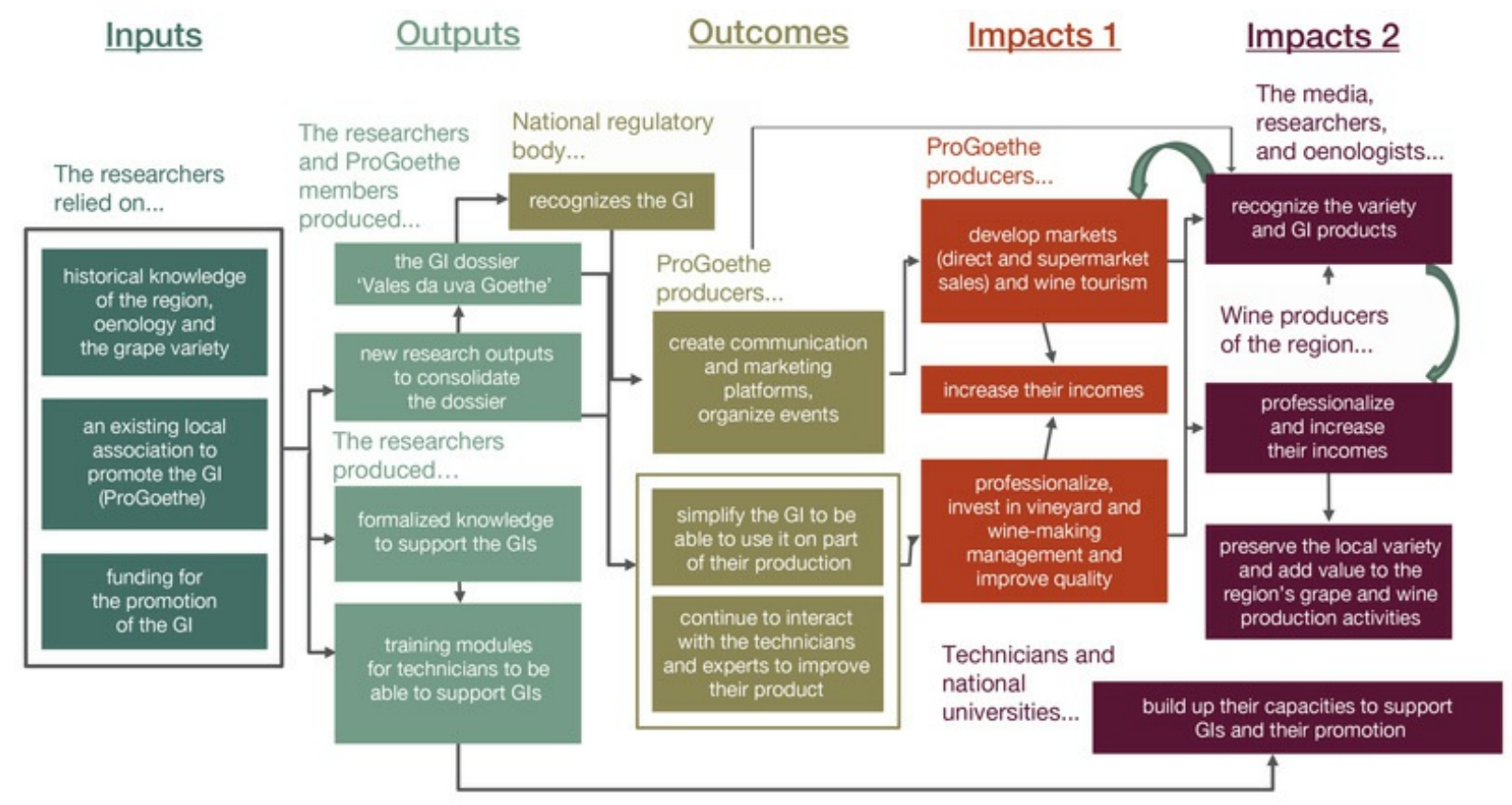

Figure 14.2. Impact pathway of the 'Vales da uva, Goethe' geographical indication innovation (drawn with Claire Cerdan's research team).

In the ImpresS approach, the evaluation of the impact begins with a participatory workshop for all the actors of the innovation in order to trace the innovation's chronological narrative and to highlight some of the lesser known parts of the process. Based on this workshop, the evaluation team can draw up the impact pathway which depicts the causal relationships of the innovation.

This impact pathway shows:

- the resources used by the research community (inputs); 
- the products of research activities (outputs);

- the appropriation and transformation of outputs by the producers who are members of the association for the promotion of the geographical indication (GI ProGoethe), especially into socio-technical mechanisms (outcomes);

- first-level impacts on actors interacting with the research community (GI ProGoethe members);

- second-level impacts on other actors who are the indirect beneficiaries of the innovation, such as the other producers in the region who are outside the ambit of the geographical indication.

All the complexity of the impact pathway resulting from the innovation's dynamic and non-linear processes is disentangled. The impact pathway shows that the innovation process is complex, involves multiple actors, and is composed of multiple causalities that can interact with each other.

As part of the evaluation of the Camargue organic rice programme, the impact pathway of the research programme was reconstructed and drawn in a participatory manner with the various actors during a workshop[49] (Quiédeville et al., 2017). The participants first identified the different changes pertaining to the transition to organic farming in Camargue since 2000. They then sought to define how, when, and where these changes occurred. Subsequently, they drew the impact pathway, taking into account the complex and dynamic nature of the innovations concerned. A specific focus was to understand the nature and intensity of the links between stages, in order to better determine the role of the research undertaken. In addition, an analysis of the social network made it possible to examine the real role played by different research institutes in the transition to organic agriculture and, as a result, validate the actors' statements (Quiédeville et al., 2018).

In order to establish the extent to which impacts are attributable to the innovation on the one hand, and to the intervention of the research community on the other, it is necessary to triangulate information from different sources. This involves a combined analysis of documents, statistics and existing studies (constituting secondary data), as well as conducting surveys using questionnaires, individual interviews or collective interviews. 


\section{Identifying and measuring the impacts}

The evaluation based on the impact pathway requires specific work to identify and measure the innovation's impacts. The two approaches selected as examples are exploratory and participatory in order to help identify the impacts of the innovation process. In the evaluation in Camargue, the impacts were primarily revealed through individual interviews. In the evaluation of the geographical indication in Brazil, the participatory workshop brought together different actors and beneficiaries of the innovation, who worked in small groups to identify impact descriptors, i.e. the effects of the innovation as the workshop participants perceived them - on their activities and their environment. These impacts can be positive or negative, expected or unexpected. They can be supplemented by the impacts expected by the research teams, for example, such as biodiversity preservation (as in the case of Camargue). In Brazil, the actors noted an unexpected impact of the geographical indication on the local economy as a whole, extending to well beyond the known producers using this geographical indication, which thus gave another dimension to the initial innovation.

Once the impacts are identified, the evaluation team looks for suitable indicators. To do so, it can rely on a study of the literature, and also look at the impact descriptors formulated by the beneficiaries. For example, in Brazil, in order to estimate the impact of the geographical indication on the professionalization of artisanal and colonial wine producers, the indicators chosen were the change in the quality of the wines, as judged in local competitions; the number of visitors to the wine festival organized in 2015 for wine with the 'Vales da uva, Goethe' geographical indication; and the change in direct and total sales by producers of wine labelled with this geographical indication.

Once the indicators are decided upon, the evaluation team collects data to quantify them and to estimate the extent to which the identified impacts are indeed verifiable in the field.

\section{Weedback on the role of evaluation in understanding innovation}




\section{An improved understanding of the causal mechanisms of innovation processes}

These two case studies enrich our understanding of the innovation process, including of the underlying causal processes. The impact pathway tool makes it possible to organize the information, and more importantly, to better understand the causal relationships between research outputs, their appropriation and adaptation by other actors and, finally, the impacts they produce. It also makes it possible to determine the cause of the observed impacts, and thus to distinguish between those resulting from the innovation being studied or its environment and those attributable to other programmes.

A detailed analysis of the impact pathway also helps determine when and where research plays a key role in the innovation process. In the case of Camargue, it was the statements of actors during the workshop that helped formulate hypotheses on the innovation process, starting from the beginning of the research programme and going up to the impacts. These hypotheses could then be confirmed, or refuted, by the evaluators (process tracing), on the basis of official documents, actual observations made on the ground, the statements of actors from individual interviews, statistics, as also an analysis of the social network to discern any changes in relationships between individuals and/or institutions. In the case of the geographical indication in Brazil, the evaluation team considered that the work on the impact pathway made it possible to impart a coherent structure to all the activities of different actors of the innovation. This tool also helped determine the activities through which the actors in the field had appropriated - or had been unable to appropriate - the outputs of the research teams (Cerdan, 2016).

In order to make the analysis more rigorous, the evaluator can also look for possible alternative explanations for the different causalities of the impact pathway (their correctness can also be verified by process tracing). This indepth analysis of the impact pathway, on the basis of the attributability of the impacts observed to the innovation, compensates for the lack of comparison with a control group (Mayne, 2001). This analysis can, however, be further strengthened, as in the case of Camargue, with the help of questions to be asked during individual interviews, such as: 'If activity $\mathrm{X}$ of the programme had not taken place, what would have happened?' These questions help 
determine the counterfactual situation, i.e. the situation without the intervention of research activities, would have been. In the same vein, the actors were asked to estimate the importance of each identified event on the impact pathway, in relation to their influence on the events that followed. This helped us to better understand the role and contribution of the research activities to the innovations, as also the contribution of these innovations to the impacts on the beneficiaries and on society.

\section{Usefulness of the evaluation for innovation actors}

These approaches for evaluating impacts have been a source of learning for the research community and other innovation actors. Workshops to present the findings and conclusions were organized in both case studies, providing actors with an opportunity to comment on the results of the evaluation.

In the case of Camargue, the evaluation of the research programme helped identify factors that facilitated or hindered the farmers in the transition to organic farming. The actors were also able to express their desire that scientific experiments be conducted in closer collaboration with farmers for improving their effectiveness. Furthermore, the evaluation revealed that researchers were too optimistic about the adoption and use of their research by the beneficiaries. It showed that while the research had positive effects, its influence was not very significant since other important factors (institutional framework, economic and political factors, etc.) also played a role. The research community has begun to take these elements into consideration. For example, the French National Institute for Agricultural Research and the French Rice Centre have initiated deeper discussions on how to work together with farmers and involve them more in defining goals and in implementing research activities, especially in terms of experimenting with agricultural practices.

In the Brazilian case, the evaluation opened avenues for reflection on the establishment of new geographical indications. The phase of appropriation and transformation of research outputs by the other actors emerged as the most critical moment for the production of impacts. Following this assessment, the research team plans to adopt a new approach to promote 
future geographical indications, by working more closely with producers, especially in the creation of various tools such as simplified guides for those involved in the creation of geographical indications. It is also planned to apply the ImpresS evaluation method to ongoing projects for registering new geographical indications, for an in itinere evaluation, focusing specifically on the risks and opportunities to be considered during the development of the innovation.

\section{Conclusion: moving towards a culture of impact to favour the learning process of the research community}

A variety of methods, tools and instruments are available to the researcher to evaluate the innovations in which he participates. A suitable method can be chosen only after defining properly the scope and goals of the evaluation as well as its openness to the actors of the innovation in question. It is also necessary to examine the nature of the innovation process itself before evaluating the impact of an innovation. Furthermore, one has to ensure that the method chosen for the evaluation is adapted to the innovation process being studied.

Complex innovation processes call for an approach based on the reconstruction of the impact pathway and the study of causal links. The impact pathway can also help build consensus amongst actors on the innovation process, identify the causal links leading to the impact, structure the collection of information on impacts, and encourage the different actors in acquiring knowledge and know-how. The challenge then lies in using the acquired knowledge and in leveraging learning in order to guide action. Promoting an impact culture in research institutions is not just about providing reports to the management of these institutions. It can help in an improved planning of research to target the impact. It can also favour a learning process for researchers in reviewing their practices so that they can better support innovation processes. 


\section{Wibliography}

Baron G., Monnier E., 2003. Une approche pluraliste et participative : coproduire l'évaluation avec la société civile. Informations sociales, 110.

Befani B., 2012. Models of Causality and Causal Inference. In: Broadening the Range of Designs and Methods for Impact Evaluation (Stern E., Stame N., Mayne J., Forss K., Davies R., Befani B., eds). Department For International Development, London, Working paper, 38.

Cerdan C., 2016. Une valeur ajoutée des produits de l'agriculture familiale du Brésil à explorer : les indications géographiques. Étude de cas ImpresS. Cirad, Montpellier.

Conley-Tyler M., 2005. A fundamental choice: internal or external evaluation? Evaluation Journal of Australasia, 4(1, 2), 3-11.

Devaux-Spatarakis A., 2014a. La méthode expérimentale par assignation aléatoire : un instrument de recomposition de l'interaction entre sciences sociales et action publique en France ?, $\mathrm{PhD}$ thesis in political science, University of Bordeaux.

Devaux-Spatarakis A., 2014b. L'évaluation basée sur la théorie entre rigueur scientifique et contexte politique. Politiques et Management Public, 31(1), 75-91.

Douthwaite B., Kuby T., van de Fliert E., Schultz S., 2003. Impact pathway evaluation: an approach for achieving and attributing impact in complex systems. Agricultural Systems, 78, 243-65.

Duflo E., 2005. Évaluer l'impact des programmes d'aide au développement : le rôle des évaluations par assignation aléatoire. Revue d'économie $d u$ développement, 19(2), 185-226.

Evaluation Gap Working Group, 2006. When Will We Ever Learn? Improving Lives Through Impact Evaluation, Report of the Center for Global Development. 
Fetterman D.M., Kaftarian S.J., Wandersman A. (eds), 2015. Empowerment evaluation: knowledge and tools for self-assessment, evaluation capacity building, and accountability. Second edition, Sage Publications, Los Angeles.

Fisher R.A., 1926, The arrangement of field experiments. Journal of Ministry of Agriculture, XXXIII, 503-23.

Mayne J., 2001. Addressing Attribution Through Contribution Analysis: Using Performance Measures Sensibly. The Canadian Journal of Program Evaluation, 16(1), 1-24.

Naudet J.-D., Delarue J., 2007. Promouvoir les évaluations d'impact à l'Agence française de développement : renforcer l'appropriation et l'apprentissage institutionnels. 02. Série Notes méthodologiques Ex Post, Département de la Recherche, Division Évaluation et capitalisation, French Development Agency.

Naudet J.-D., Delarue J., Bernard T., 2012. Évaluations d'impact : un outil de redevabilité ? Les leçons tirées de l'expérience de l'AFD. Impact Evaluations: a tool for accountability? Lessons from experience at AFD. Revue d'économie du développement, 20, 27-48.

OECD, 2002. Glossary of Key Terms in Evaluation and Results Based Management. OECD Publishing, Paris, $<$ http://www.oecd.org/development/peer-reviews/2754804.pdf $\rightarrow>$ (retrieved 24 July 2018).

Patton M.Q., 1997. Utilization-Focused Evaluation: The New Century Text. Thousand Oaks/Sage Publications, London, New Delhi.

Patton M.Q., 2001. Qualitative Evaluation and Research Methods. 2nd edition, Sage Publications, Thousand Oaks, CA.

Quiédeville S., Barjolle D., Mouret J.-C., Stolze M., 2017. Ex-Post Evaluation of the Impacts of the Science-Based Research and Innovation Program: A New Method Applied in the Case of Farmers' Transition to Organic Production in the Camargue. Journal of Innovation Economics and Management, 22(1), 145-145. 
Quiédeville S., Barjolle D., Stolze M., 2018. Using Social Network Analysis to Evaluate the Impacts of the Research: On the Transition to Organic Farming in the Camargue. Cahiers Agricultures, 27(1), 1-9.

SFE, 2011. L'évaluation des impacts des programmes et services publics. Société Française d'Evaluation, Les cahiers de la SFE, 6.

Shadish W.R., Cook T.D., Leviton L.C., 1991. Social Program Evaluation: Its History, Tasks, and Theory. In: Foundations of Program Evaluation: Theories of Practice (W.R. Shadish, T.D. Cook, L.C. Leviton, eds), Sage Publications, Newbury Park, Calif, 19-35.

Weiss C.H., 1972. Evaluation research: methods for assessing program effectiveness. Prentice-Hall methods of social science series, Prentice-Hall, Englewood Cliffs, N.J.

\section{Chapter 15}

\section{Evaluating impacts of innovations: benefits and challenges of a multi-criteria and participatory approach}

\section{JeAn-Marc Barbier and Yuna Chiffoleau}

Summary. To support actors to migrate to more sustainable food systems, multicriteria evaluation tools are required to explore the effects and impacts of technical and organizational innovations. In this chapter, we present two possible constructions and uses of such tools: the first involves support for agroecological transitions on farms, and the second aims to compare two food chain models, one local and the other global. These two examples allow us to address and discuss three methodological fronts: the taking into account of the multiple dimensions and properties of sustainable systems, in a search for comprehensiveness across environmental, economic and social dimensions; 
actor participation in identifying and developing evaluation criteria and indicators; and the manner in which to arrive at a final assessment through the choice of methods for measuring, scoring, weighting and aggregating indicators or performance calculations.

If innovation is a process by which a new idea, concept or object becomes a functional system that is adopted and mastered by the actors (in this case, actors in food chains, i.e. chains linking agricultural production, raw-material processing, marketing and consumption of food products), then it must be admitted that the changes actually implemented, as also the effects and impacts[50] of the process, can rarely be known in advance. On the one hand, the concept or the original object is apprehended and adapted in varying ways by different individuals and, on the other, the interactions within the production systems in which the innovation takes place lead to reorganizations whose nature is difficult to foresee, especially at scales that exceed those of the implementation of the concept or the object (Flichy, 2003). Finally, it is not always easy for the actors involved in the innovation process to project themselves forward in time and anticipate medium-term, long-term, or even long-distance effects.

It has been shown that the dissemination of a technical production system such as organic farming, which is considered inherently beneficial due to its low environmental impact, could lead to regional land-use patterns deemed unsustainable by the same actors who initially promoted these very systems (Delmotte et al., 2016). This shows the potential contradictions of any innovation process. Moreover, the point of view on the same innovation process often varies from actor to actor. The challenge is then not only to create a list of criteria and indicators[51] to evaluate an innovation in several dimensions, but also to allow different types of actors, in addition to researchers, to participate in defining these indicators to ensure that different points of view are taken into account.

Developments in agriculture have triggered interference from society, more specifically from citizen groups (e.g. consumers, environmental associations), in the management of agricultural affairs (Pujol and Dron, 1999). The rise in the influence of civil society on these issues, the exacerbation of agricultural crises linked to scandals, be they related to health or food matters or to certain technical models, and the awareness of issues hitherto barely recognized (fine particulate pollution, obesity, etc.) have made agriculture a 
sector that is under constant and close surveillance. There has been a marked increase in the number and diversity of actors involved in and of points of view of agriculture.

According to the literature on agriculture, approaches for designing - or for assistance in designing - innovative technical systems rely on evaluation methods in which existing or proposed systems (whether they originate from the research community or are inspired by the innovations of some pioneering actors) are measured by the yardstick of a number of so-called 'performance' indicators (Lairez et al., 2015). However, these evaluation methods often exhibit some flaws:

- since they are focused on the agri-environmental dimension, they pay scant heed to social criteria;

- since they are concerned about evaluating direct impacts, they rarely examine the effects of innovation on the reorganization of socio-technical systems;

- they rarely rely on the actors' points of view and on their criteria for satisfaction.

In order to improve evaluation methods, it may be necessary to take the point of view of the farmers who are directly involved into better consideration, through a reassessment of their usual practices, as well as those of their representatives and/or persons who provide support to them in their change of practices. More broadly, it may also entail incorporating the points of view of other actors concerned by agricultural innovations, such as traders, consumers or even ecologists, local inhabitants, citizens, etc.

This chapter's objective is to show, on the basis of two case studies, the benefits and limitations of methods for the multi-criteria evaluation of innovations, which propose an overall vision, rely on a concept of strong sustainability and involve different actors.

In the first case study, we show how a group of experts, of which we were part, sought to renew a method for evaluating farm sustainability (the IDEA method) to better understand the overall performance of farms that are in a relatively advanced stage of transition towards agroecology. In the second case study, we present the participatory creation of an evaluation method to compare two food chain models, one local, the other global. In each case, we 
highlight some key methodological aspects. We then discuss the coconstructed and multi-disciplinary nature of these tools by repositioning them in the evolution of multi-criteria evaluation approaches in agricultural research (Sadok et al., 2008), on the one hand, and in the perspective of a democratic regime of performance evaluation (Jany-Catrice, 2012), on the other.

\section{A renewal of the IDEA method to evaluate a farm's agroecological transition}

A major challenge for agricultural development today is to define methods to support and assess agroecological transitions on agricultural farms. Monitoring and evaluation procedures based on lists of good practices to be identified on farms in transition cannot guarantee the establishment of a system that is really more sustainable. To do so, we need to be able to assess the overall performance of the transition, i.e. the effects and potential impacts, at different scales and for a wide range of performance domains (environmental, economic, social, ethical, well-being and health). To this end, we have taken recourse to the IDEA method, one that is already recognized for its educational and comprehensive nature, but after modifying it to suit our purpose.

\section{The IDEA method for assessing farm sustainability}

The IDEA (French: Indicateurs de durabilité des exploitations agricoles, Farm Sustainability Indicators) method (Vilain, 2008) was designed to support actors in the fields of academics, professional education and agricultural extension. The aim was to provide teachers and agricultural advisers with an operational tool to effectively break down the concept of sustainability and this for all forms of agriculture in the French national territory. Sustainable agriculture, according to the IDEA method, is defined as agriculture that is ecologically sound, economically viable, socially just and humane (Zahm et al., 2015). This is why IDEA aggregates indicator scores to arrive at three evaluation dimensions: agri-environmental, socioterritorial, and economic. IDEA also subscribes to the concept of robust 
sustainability, in which the assumption of substitutability of different forms of capital (manufactured, human and natural capital, as well as stocks of knowledge and know-how) is rejected. Thus, in IDEA, aggregation between the three pillars of sustainability (economic, social and environmental) is not possible. The final assessment of farm performance, in terms of sustainability, is based on three juxtaposed scores (Figure 15.1).

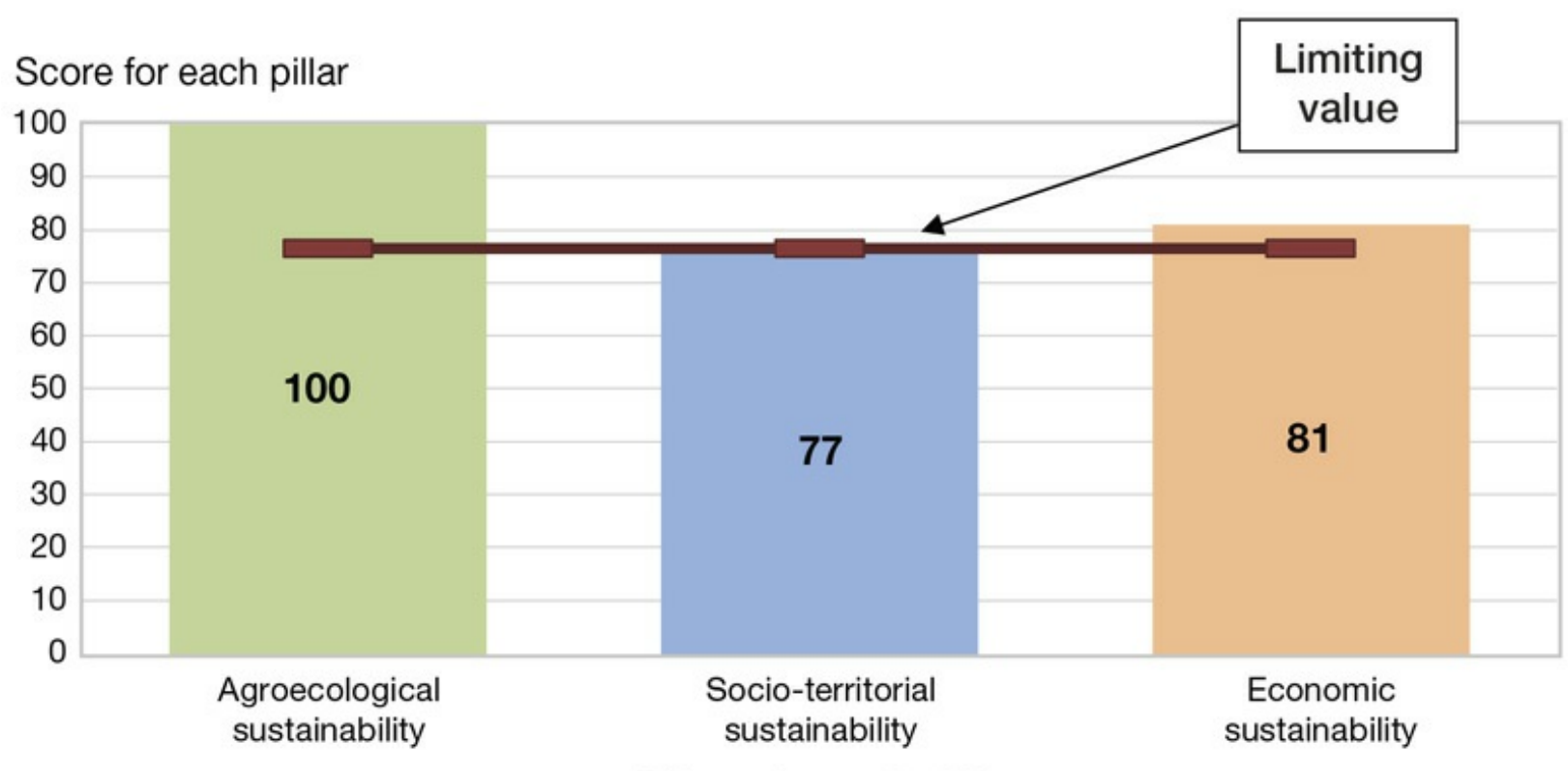

Pillars of sustainability

Figure 15.1. Example of an evaluation of farm performance based on the three pillars of sustainability.

The maximum score for each pillar is 100 . Since there is no substitutability, the lowest score determines the level of sustainability.

\section{A renewed method to evaluate innovations and agroecological transitions}

Considered in its wider definition, agroecology (Doré et al., 2011) not only concerns new agricultural and environmental functions that must be fulfilled by agriculture, but also the broader objectives of contributing to the sustainability of society as a whole. For this, the IDEA method needs to be modified, because in its original form it fails to capture the impacts of the farm on global changes (for example, climate change), the exacerbation of 
uncertainties arising from these changes, a number of key concepts related to agroecology (autonomy, circular economy, frugality) and the issue of food.

\section{Defining the categories of the experts concerned}

A first step was to determine the participants who should be involved in the evaluation tool's construction. A project group was assembled, comprising experts from different professions (researchers, teachers, members of specialized technical institutes) and from different scientific disciplines (agronomy, zootechnics, sociology, management sciences, economics, etc.) covering, through their combined experience, the diversity of production systems and chains (field crops, viticulture, livestock farming, etc.), and representatives of the major French agricultural regions (Mediterranean, mountains, etc.). This group was tasked with developing a didactic tool for assessing farm sustainability, which could not only be easily used to train and support farmers, but would also be relevant to the entire gamut of French agriculture[52], and which would take into account new issues and knowledge related to agroecology. This group was active throughout the design process, and in all the steps detailed below.

\section{Defining the boundaries of the system to be evaluated at different scales}

After agreeing on revised definitions of the concepts of sustainability, sustainable agriculture and sustainable farms in terms of a robust sustainability, the experts were called upon to define the boundaries of the system being studied and the scales of evaluation. We decided, in line with Bossel (1998) and Terrier et al. (2013), that the criteria retained would have to simultaneously encompass two notions (Figure 15.2):

- on the one hand, the durability of the farm, referred to here as 'limited sustainability', which implies that the farm must be sustainable by and for itself, through practices that ensure the reproduction of the system and of its subsystems; 
- 'extended sustainability', on the other hand, which means that the farm contributes to the sustainability of the nested organizational levels it belongs to, be it level 1 (local or territorial scale, for example, which can generate local synergies between different types of production systems), or level 2 (national or even global scale, notably through contributions to the carbon balance or greenhouse gas emissions). It is this stance that led, for example, to examine livestock feeding choices with regard to the consequences of deforestation in the tropics.

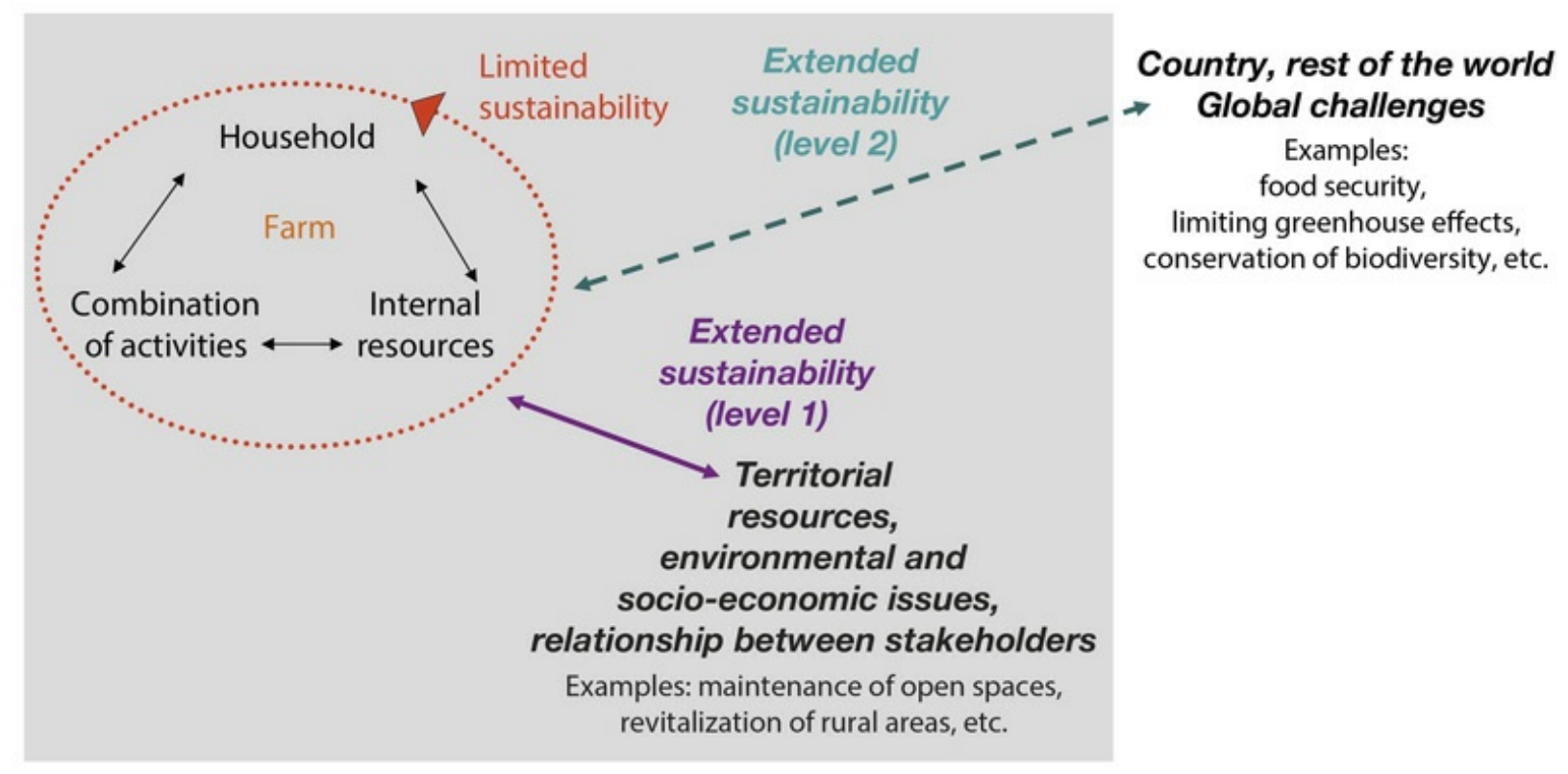

Figure 15.2. The system being analysed, the scales of evaluation and the different levels of sustainability taken into account in the IDEA method (Terrier et al., 2013).

\section{Renewing the conceptual framework}

In the second step, the experts came to an agreement on ways to represent the sustainability of agriculture and the farm. Two avenues were chosen in the new IDEA method:

- sustainability as an ability to meet or address goals, which represent, at a given moment, a societal consensus on the functions that agriculture must fulfil (preserving biodiversity, ensuring animal health and welfare, protecting water resources, etc.); 
- sustainability as a set of emerging properties and attributes of a sustainable system (Lopez-Ridaura, 2002).

Thus, in IDEA, five properties were selected, the first three being strongly dictated by agroecological innovation, in that it comprises agronomic and technical issues. These include:

- productive and reproductive capacity;

- robustness;

- autonomy;

- territorial anchoring;

- global responsibility (Zahm et al., 2015).

\section{Defining criteria and indicators, and agreeing on weighting and the aggregation method}

On the basis of this conceptual framework, the next step was to redefine and structure the hierarchical construction of the criteria and corresponding indicators[53]. A total of 54 indicators were finally selected. On this point, the IDEA method relies on two major characteristics - a mix of quantitative and qualitative indicators and the development of scoring scales - to place the absolute value of an indicator in a normalized range of possible values, and to convert the absolute value into a sustainability score or points. For some qualitative indicators such as quality of life or work stress, the IDEA method relies on a self-evaluation by the farmer, thus expanding the categories of actors contributing to the evaluation. When the indicators are quantitative, the value is evaluated against national or regional references. For example, the indicator for water-use on the farm compares the reported annual consumption with national statistical values (averages and quantiles) established for each major type of production (viticulture, arboriculture, dairy farming, etc.).

The method of weighting and aggregation of indicators (to go from subindicators to indicators, then to criteria and, finally, to the five attributes constituting sustainability) was the most contentious. Ultimately, the IDEA method is not much concerned by the weightage of indicators and criteria. It 
barely does so in the agroecological dimension where, for example, the experts did not want to decide between the importance accorded to groundwater pollution, air pollution, soil fertility and climate change. Weighting is also relatively ignored in the territorial dimension, where the contribution to local development counts for as much as to the quality of life and relationship to work. On the other hand, it intervenes a little more strongly in the economic dimension, where certain economic indicators and overall farm efficiency are considered more important than others (for example, for the criterion of economic and financial autonomy, the method gives more weight to the indicators of the diversity of productions and contractual relationships than to perceived public support indicators).

We will now show how another approach, focused on the evaluation of food chains and associated innovations, also led us to debates on criteria and indicators, and issues related to their weighting or hierarchization. This alternative approach, however, saw the participation of actors of innovation themselves in the debates.

\section{Whe participatory construction of a multi- criteria evaluation of food chains and associated innovations}

\section{Defining the objects of the analysis}

Are short food chains more sustainable than long ones? The actors who worked for their revival in industrialized countries, as early as the 1970s in Japan and only later in France (Maréchal, 2008), are often convinced they are. Even though this question was hardly accorded any importance until recently, it is now at the heart of many debates. These debates not only concern the effects of a limited number of intermediaries, - according to the official definition of short chains in France[54] -, they contrast at least two very different models of food chains that we described, as part of the European research project Glamur[55], through the notions of local and global food chains. Local and global chains correspond a priori to two extreme 
cases of food chains, based on five factors that we selected in the project to differentiate food chains in general:

- the number of intermediaries between the producer and the consumer;

- the geographical distance between production and consumption;

- the origin and nature of the resources used in the chain (raw materials, inputs, technologies, etc.);

- the governance of the chain;

- the type of attributes used to characterize the product's identity.

The Glamur project thus aimed to describe local and global chains in each country and for different types of products in order to compare their performances. It is interesting to note that local chains were considered innovative for some project partners (for example, in Spain and England) while others thought global chains were innovative (in Latvia). The local and global food chains for ten products were compared by the project partners in terms of five performance areas, each corresponding to a dimension of sustainable development, i.e. the economic, social, environmental, ethical, and health dimensions.

We studied two products in France illustrating a different relationship between the local and the global: wine, linked to specific territories (appellations of origin, etc.) but often marketed at great distance and which, in this sense, is both a local and a global product, and the tomato, which can be considered a flagship of local food chains. As wine was already the subject of a publication (Touzard et al., 2016), we summarize here the study conducted on the tomato chains in order to illustrate the principles of a participatory multi-criteria approach. Our approach followed the general framework of the Glamur project (Brunori et al., 2016), adapting it to the specificities of the French context and anchoring it further to the principles of economic sociology, given that the economic activities - referring here to agricultural and commercial practices - are embedded in social structures (networks, moral values, institutions, etc.) that influence their forms and their effects (Granovetter, 2000).

\section{Structuring different levels of participation}


The first stage of the research carried out in France, common with the study on wine, consisted of questioning a variety of experts on the criteria to be taken into account to analyse and compare the performance of local and global food chains. We selected 20 experts who are well-known in France for their research, their activities or their positions on this subject. The selection was also designed to bring together experts from the four spheres concerned with the sustainability of local and global food chains, i.e. the research community, the economic sector, public policies, and civil society. These experts came up with some 30 criteria to characterize local and global chains, or to compare them, by referring to innovations deployed in each chain (innovations such as partnerships between producers and consumers in local chains, or precision agriculture in global chains). This list of quantitative and qualitative criteria proposed by the experts was complemented by an analysis of documents originating from the four spheres mentioned above - more than 500 publications, reports, websites, pleas, etc. were analysed. The criteria were then ranked according to the five performance areas identified in the Glamur project.

In the second stage, we formed a second group of experts which, while maintaining the participation of citizen representatives, included experts on the tomato. The group was thus made up of researchers with different specialties (production, nutrition, long chains, short chains, etc.), technicians, development agents, producers, a wholesaler, a distributor, consumers and an elected community representative. In order to facilitate the evaluation, we validated with them a model for each chain, both archetypical and representative of a dominant trend in the tomato industry. Two typical situations were selected in the south of France to represent these two models: - for the local chain, we selected one that dealt with old varieties of tomatoes that were grown around the city of Montpellier, sold at the farm gate, or distributed in Montpellier or nearby open-air markets;

- for the global chain, we selected one that dealt with hybrid tomato varieties, that were grown in unheated greenhouses in southern Spain (Almeria province in Andalusia), and distributed in supermarkets in Montpellier.

In the third stage, the experts of the second group took note of the criteria defined by the first, validated, fine-tuned and finalized them, producing ultimately 32 performance evaluation criteria. The work with this second 
group of experts consisted in particular in clarifying the method for evaluating these criteria, by breaking down each of them into several relevant quantitative and/or qualitative indicators, by discussing the method of calculating or setting scores for each indicator, which itself was broken down, whenever necessary, into sub-indicators, and defining a 'benchmark', so that the performance of food chains in terms of each indicator could be calculated.

\section{Calculating the performances}

In our case study, for indicators favourable to sustainability, such as contribution to employment, the benchmark corresponds to a high reference value or a score which, from the point of view of sustainable development, is desirable to attain or exceed; achieving this benchmark is possible under certain conditions. For indicators that are detrimental to sustainability, such as the quantity of greenhouse gases produced along the chain, the benchmark is set at a maximum value or score that should never be achieved or breached, according to experts.

Setting a benchmark then makes it possible to calculate the performance of the chain with regard to each indicator. For favourable indicators, the performance is calculated according to whether the value or the score evaluated for the indicator considered falls between $0 \%$ and $100 \%$ of the benchmark, or even exceeds $100 \%$. For detrimental criteria, the performance is inversely proportional to the percentage that represents the value or the score evaluated for the indicator with regard to the benchmark

While defining benchmarks may appear to be relatively simple for quantitative indicators, it is far less so for qualitative indicators. To evaluate qualitative indicators favourable to sustainable development and to define benchmarks, experts were invited to identify good practices or factors that promoted a high performance for each of the selected indicators. These good practices and/or factors constituted a list of sub-indicators, whose scores were then added to arrive at a score for the indicator concerned. On the other hand, to evaluate unfavourable indicators, experts listed bad practices that are detrimental or contrary to sustainable development. 
As illustration, we present here three examples of indicators, each referring to one of the dimensions of sustainability:

- for the indicator of net farm income per working member (economic dimension of sustainability), of a quantitative nature, the group of experts selected as a benchmark, i.e. as a performance level of $100 \%$, the maximum agricultural income recorded in France; the income of the producer at the bottom of the local or global tomato chain was thus compared to this value;

- for the indicator of conservation of agricultural biodiversity (environmental dimension of sustainability), of a qualitative nature, the benchmark chosen is a score of 7 , consisting of the sum of good practice scores (corresponding to sub-indicators) that can already be observed in either one or the other chain (Table 15.1); a score of 7 achieved by a chain then corresponds to a performance of $100 \%$ with regard to the indicator of conservation of cultivated biodiversity;

- for the criterion of relationship between the producer and the consumer (social dimension of sustainability), also of a qualitative nature, the benchmark is a score of 10 , corresponding to the sum of factors favourable to a strong producer-consumer relationship (Table 15.1).

Table 15.1. Choice of sub-indicators that allow the setting of benchmarks for two qualitative indicators favourable to the sustainability of the tomato chains.

\begin{tabular}{|c|c|c|c|}
\hline $\begin{array}{l}\text { Indicator } \\
\text { favourable to } \\
\text { sustainability }\end{array}$ & Sub-indicator of good practice & \begin{tabular}{|l|} 
Score \\
assigned \\
to each \\
practice \\
\end{tabular} & \begin{tabular}{|l|} 
Maximum \\
score to \\
achieve \\
(benchmark)
\end{tabular} \\
\hline \multirow{4}{*}{$\begin{array}{l}\text { Preservation } \\
\text { of cultivated } \\
\text { biodiversity }\end{array}$} & Diversity of the agricultural model & 2 & \multirow{4}{*}{7} \\
\hline & $\begin{array}{l}\text { Diversity of cultivated varieties (in number of } \\
\text { varieties) }\end{array}$ & 0 to 2 & \\
\hline & $\begin{array}{l}\text { Implementation of biodiversity conservation } \\
\text { practices (for example, biological pest control) }\end{array}$ & 0 to 2 & \\
\hline & Cultivation of old varieties & 1 & \\
\hline \multirow{4}{*}{$\begin{array}{l}\text { Relationship } \\
\text { between the } \\
\text { producer and } \\
\text { the consumer }\end{array}$} & Geographical proximity & 1 & \multirow{4}{*}{10} \\
\hline & Sale and/or meeting at the farm & 1 & \\
\hline & $\begin{array}{l}\text { Mechanisms or mediations favouring a strong } \\
\text { relationship (in number of mechanisms) }\end{array}$ & 0 to 4 & \\
\hline & Information exchanged between producers and & & \\
\hline
\end{tabular}


consumers through the relationship on

production methods, working conditions, etc.

(in number of items of information exchanged)

\section{Discussing the measurements and results}

Following the co-construction of this first grid of indicators, the scores were evaluated based on concrete data, produced or collected for each of the chain models. For the local chain, we presented to the experts the results of indepth surveys of some 20 farms representative of the chosen model, which we put in perspective with surveys of a larger sample (Bellec-Gauche and Chiffoleau, 2015). For the global chain, we provided very extensive secondary data from recent theses on tomato farms in Andalusia, as well as interviews with resource persons in Spain. This data helped fine-tune the first grid of indicators and helped fix the values or scores for each indicator, for each chain.

However, the goal was not so much to arrive at absolute values as it was to understand the strengths and limitations of each of the two food chain models through the practices implemented, both current and innovative. Therefore, we did not aggregate the values or scores at the level of each sustainable development dimension, but instead retained the performance calculations for each indicator. The results ultimately showed that neither of the two chains is, based on the full set of indicators, more efficient than the other. Each chain is better according to some indicators, and exhibits worse performance according to others. However, while this finding has provided fodder to some experts to argue for the coexistence of different agricultural models, others have pointed out that some indicators are more important than others, and have thus introduced the prospect of a possible hierarchy between the two types of chains. Other experts have moved the discussion towards an evaluation of the performances with regard to the means available to the actors (access to land, subsidies, technologies, etc.) and the constraints to which they are subjected (organization of the work in particular), thus highlighting the efficiency of local chains, which have fewer resources and face more constraints than global chains. These conclusions lead us to compare this approach with the new IDEA method, to open a wider 
discussion on the modalities and challenges of a multi-criteria and participatory evaluation of innovations.

\section{Weedback on questions raised by the evaluation of innovations}

\section{What is the purpose of evaluating innovations?}

The two examples presented here illustrate how to implement multi-criteria evaluation procedures. This is not so much to arrive at absolute performance values or to compare systems objectively. The challenge is instead to encourage the actors involved to consider the impacts and possible effects of certain choices and to better understand the advantages, as well as the limitations, of the different possibilities of change available to them.

The IDEA (Farm Sustainability Indicators) method was not initially meant to evaluate innovations. Its goal was, in the context of the Rio Conference and the emergence of the multi-functionality of agriculture in France, to translate the concept of sustainability into an operational tool, and to train agricultural teachers and students using a normative approach so that they, in turn, could support farmers in this direction. Of course, comparing different systems has led to the identification of forms of agricultural systems that are more sustainable than others. The demand to compare different types of agricultural systems (biological, reasoned, agroecological, etc.) has thus increased, leading the designers of the IDEA method to focus increasingly on these comparisons, as also on the assessment of change and support for it. IDEA, with its global approach based on indicators that are, for the most part, easily measurable, can evaluate the effects of innovative systems (reconfigured and stabilized systems) which represent clear breaks from dominant systems. However, it is unsuitable for evaluating innovations that lead only to incremental changes (for example, a simple change in equipment for applying pesticides). Wherever IDEA has been implemented, users have highlighted the method's usefulness because of its comprehensive character and its usability at different scales. Indeed, it reveals the effects or consequences of certain changes that farmers did not give any thought to (for 
example, food issues, losses and waste, and waste management). This allows the farmer to correct and fine-tune his farm's trajectory of transition, and the actors who advise him to better apprehend the complexity of the changes.

In the Glamur project, the multi-criteria approach was regarded both as an approach for producing new knowledge on food chains, and as a tool to help all the actors in these chains adopt an approach for progress. Moreover, while the project's aim was not to contrast local and global chains, it nevertheless served, for some of the project's designers, to provide a set of arguments and concrete leads to public policies to support local sustainable chains, and this in a context that is still largely oriented towards global chains.

\section{How to evaluate innovations? Feedback on multi- criteria evaluation}

Multi-criteria evaluation is distinct from multi-criteria analysis. The latter notion, originating from the management sciences, is a decision support tool, created to solve complex problems that include qualitative and/or quantitative aspects in a decision-making process (Roy, 1985). Multi-criteria evaluation, on the other hand, is not directly concerned with a decision-making objective, but more with a diagnosis of a situation. Unlike a multi-criteria analysis, an evaluation includes a comparison of the system being studied to known systems, or positions its results in relation to reference values. As we have seen, whether for the IDEA method or for the Glamur project, it is not the indicators' absolute values that allow the evaluation of a system, but how far these values are from those taken by these same indicators in another system or in a reference system (Acosta-Alba and Van der Werf, 2011).

In taking this reflection further, we emphasize that the approaches used are not necessarily aimed at helping choose the best system, but instead offer an open evaluative outlook on a set of criteria, without defining a hierarchy or reference between the evaluated systems. In the end, the approach mainly serves to modify the representations and to promote the learning of the actors (Chia et al., 2009). In this perspective, the challenge is also to widen the scope of analysis beyond the indicators typically considered, by taking into account, as was done in the case of the Glamur project, the concerns and 
experience of a variety of actors. The approach there was explicitly part of the research on new wealth indicators (Gadrey and Jany-Catrice, 2005) that sought to broaden the evaluation of wealth produced by economic activities beyond the GDP (Gross Domestic Product) alone, by assigning value to the practices of the actors of the innovations. Some researchers of Glamur, however, refused to translate qualitative criteria into scores, considering them too subjective to be evaluated, even through the aggregation of good practices. The same controversies arose during the renewal of the IDEA method. Subjectivity was, nevertheless, taken into account, since farmers were allowed to undertake a self-assessment for certain criteria, sometimes in combination with a criterion considered more objective. For example, economic viability is apprehended not only through net income per worker with respect to the minimum wage, but also by enquiring with the household about its degree of satisfaction with this income.

\section{Evaluation of innovations, with whom and in what perspective? Deliberative regime and 'global performance'}

In the IDEA method, criteria and indicators are specified and developed by researchers, teachers, trainers and members of specialized technical institutes. In other words, the perspective on the systems is that of non-farmer experts, in terms of their idea and perceptions of a conception of agricultural sustainability, of the concerns and issues raised by society and included in the agenda of national or international bodies, and of what is said by the scientific literature and expert reports on French agriculture and the functioning of a diversity of farms. Farmers and their direct representatives do not participate directly in the evaluation because the designers of the method thought it important to function independently of pressure groups and special interests. Indeed, at the time of the creation of IDEA, in the late 1990s, they considered it essential to remain outside the thinking of reasoned agriculture, for example. This approach, however, has its limitations as the institutions are often found lagging behind what actors - in this case, farmers - do and know (Darré, 1999). 
In the Glamur approach, the actors of the innovations were directly involved in the evaluation, alongside researchers and development agents, and we sought to take into account actors who were representative of the different strategies observed. The critical participation of all, however, implies that the actors have sufficient knowledge of what is at stake in the evaluation, and are conversant with its procedures (Friedberg, 1988). In this sense, participation is by choice, and cannot be decreed, for fear of becoming manipulative. In seeking to create the conditions for this critical participation, the Glamur approach sought to experiment with a concrete form of implementation of a deliberative 'global performance' regime (Jany-Catrice, 2012), in which both the criteria and the ways to evaluate them are decided collectively, with all the actors concerned, ensuring that they can actually participate.

Finally, in IDEA as in Glamur, we believe that indicators for evaluating innovation cannot be reduced to measuring instruments. Instead, they are also tools for mediation and coordination, and can even be intermediate objects (Vinck, 1999), learning aids and creators of links, revealing both objective dynamics and the subjective way in which society perceives sustainable development. As objects that allow heterogeneous actors to discuss and arbitrate, they are also a medium for a democratic process that is considered to be conducive to the transition of food systems (Lang, 1998).

\section{Conclusion: lessons from the two case studies}

In an agriculture and agrifood sector facing new challenges (Chapter 2), the implementation of innovations that have a high level of performance across multiple criteria takes on a major strategic dimension. In this chapter, we have presented and compared two examples of application of multi-criteria evaluation to support processes of change concerning the agroecological transition of farms and the establishment of more sustainable food chains. Because the challenge is to take into account all the dimensions of sustainable development, which may be difficult to reconcile, we highlight the benefits as well as the difficulties of a multi-criteria and participatory evaluation. In particular, in both examples, we underline the advantages of translating qualitative data on to a quantitative scale and of discussing the controversies that this translation may generate. This approach helps better 
explain the issues surrounding innovations, not only in terms of effects on their actors, but also on scientific and methodological issues to be pursued further.

However, using multi-criteria evaluation methods to accompany innovation will always be problematic since innovative practices are often unstable, whose effects are not well known. In addition, farmers, food chain intermediaries, as also advisers and researchers, are liable to miss a bigger picture due to their proximity to the innovation concerned. This uncertainty of knowledge on the processes involved calls for great prudence, as most of the data for identifying impacts and documenting potential consequences are still missing. More radically, the use of these tools to help the de novo design of new systems is not yet possible and requires further exploration.

\section{Acknowledgments}

This chapter could not have seen the light of day without the work undertaken jointly, since 2012, by all the members of the scientific council of the IDEA method: F. Zahm (moderator and manager) as well as A. Alonso Ugaglia, H. Boureau, B. Del'homme, M. Gafsi, P. Gasselin, L. Guichard, C. Loyce, V. Manneville, A. Menet and B. Redlingshöfer. We would also like to thank A. Barbottin, with whom J.M. Barbier wrote, on behalf of the 'SAD' department of the National Institute of Agricultural Research, a review of the research on multi-criteria evaluation within the department. In a similar vein, we thank the research group of the European project Glamur within which, with the participation of J.M. Touzard of the 'Innovation' joint research unit, we were able to discuss and formulate a specific approach based on a common framework.

\section{Bibliography}

Acosta-Alba I., van der Werf H.M.G., 2011. The use of reference values in indicator-based methods for the environmental assessment of agricultural systems. Sustainability, 3, 424-442. 
Bellec-Gauche A., Chiffoleau Y., 2015. Construction des stratégies et des performances dans les circuits courts alimentaires : entre encastrement relationnel et gestionnaire. Revue d'études en agriculture et environnement, 96(4), 653-676.

Bossel H., 1998. Earth at a crossroads: Paths to a sustainable future. Cambridge University Press, Cambridge.

Brunori G., Galli F., Barjolle D., van Broekhuizen R., Colombo L., Giampietro M., Kirwan J., Lang T., Mathijs E., Maye D., de Roest K., Rougoor C., Schwarz J., Schmitt E., Smith J., Stojanovic Z., Tisenkopfs T., Touzard J.-M., 2016. Are Local Food Chains More Sustainable than Global Food Chains? Considerations for Assessment. Sustainability, 8, 449. $<$ http://www.mdpi.com/2071-1050/8/5/449/pdf «>> (retrieved 1 August 2018).

Chia E., Rey-Valette H., Lazard J., Clément O., Mathé S., 2009. Évaluer la durabilité des systèmes et des territoires aquacoles : proposition méthodologique. Cahiers Agricultures, 18, 211-219.

Darré J.-P., 1999. La production de connaissance pour l'action. Arguments contre le racisme de l'intelligence. Éditions de la Maison des sciences de l'homme, Paris.

Delmotte S., Barbier J.-M., Mouret J.-C., Le Page C., Wery J., Chauvelon P., Sandoz A., Lopez-Ridaura S., 2016. Participatory integrated assessment of scenarios for organic farming at different scales in Camargue, France. Agricultural Systems, 143, 147-158.

Doré T., Makowsky D., Malézieux E., Munier-Jolain N., Tchamitchian M., Tittonell P., 2011. Facing up to the paradigm of ecological intensification in agronomy: revisiting methods, concepts and knowledge. European Journal of Agronomy, 34, 197-210.

Flichy P., 2003. L'innovation technique. Récents développements en sciences sociales. Vers une nouvelle théorie de l'innovation. Collection Sciences en société, La Découverte, Paris.

Friedberg E., 1988. L'analyse sociologique des organisations. Pour, 28. 
Gadrey J., Jany-Catrice F., 2005. Les nouveaux indicateurs de richesse. La Découverte [3rd edition 2012], Paris.

Granovetter M.S., 2000. Les marchés autrement. Les réseaux dans l'économie. Desclée de Brouwer, Paris.

Jany-Catrice F., 2012. La performance globale : nouvel esprit du capitalisme? Presses du Septentrion, Villeneuve d'Asq.

Lairez J., Feschet P., Aubin J., Bockstaller C., Bouvarel I., 2015. Évaluer la durabilité en agriculture. Guide pour l'analyse multicritère des productions animales et végétales. Éditions Quæ/Educagri, Versailles/Dijon.

Lang T., 1998. Towards a food democracy. In: Consuming passions: Cooking and eating in the age of anxiety (S. Griffiths, J. Wallace, eds), Mandolin, Manchester, 13-24.

López-Ridaura S., Masera O., Astier M., 2002. Evaluating the sustainability of complex socioenvironmental systems. The MESMIS framework. Ecological Indicators, 2, 135-148.

Maréchal G., 2008. Les circuits courts. Bien manger dans les territoires. Educagri, Dijon.

Pujol J.-L., Dron D., 1999. Agriculture, monde rural et environnement : qualité oblige. Report for the Minister of the Environment and Regional Planning. La documentation Française, Paris.

Roy B., 1985. Méthodologie multicritère d'aide à la décision. Economica, Paris, $423 \mathrm{p}$.

Sadok W., Angevin F., Bergez J.E., Bockstaller C., Colomb B., Guichard L., Reau R., Doré T., 2008. Ex ante assessment of the sustainability of alternative cropping systems: implications for using multi-criteria decisionaid methods. A review. Agronomy for Sustainable Development, 28, 163-174.

Terrier M., Gasselin P., Le Blanc J., 2013. Assessing the Sustainability of Activity Systems to Support Households' Farming Projects. In: Methods and 
Procedures for Building Sustainable Farming Systems. Application in the European Context (Marta-Costa A.A., Soares da Silva E., eds), Springer, Dordrecht (The Netherlands), 47-61.

Touzard J.-M., Chiffoleau Y., Maffezzoli C., 2016. What is local or global about wine? An attempt to objectivize a social construction. Sustainability, 8(5), 417, 20 p. [Online, open access] <http://www.mdpi.com/2071-

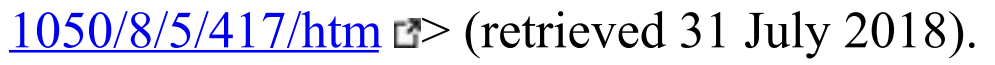

Vilain L. (ed.), 2008. IDEA : Indicateurs de durabilité des exploitations agricoles. 3rd updated edition, Educagri, Dijon, $184 \mathrm{p}$.

Vinck D., 1999. Les objets intermédiaires dans les réseaux de coopération scientifique. Contribution à la prise en compte des objets dans les dynamiques sociales. Revue française de sociologie, 40(2), 385-414.

Zahm F., Alonso Ugaglia A., Boureau H., Del'homme B., Barbier J.-M., Gasselin P., Gafsi M., Guichard L., Loyce C., Manneville V., Menet A., Redlingshofer B., 2015. Agriculture et exploitation agricole durables : état de l'art et proposition de définitions revisitées à l'aune des valeurs, des propriétés et des frontières de la durabilité en agriculture. Innovations agronomiques, 46, 117-137.

\title{
Chapter 16
}

\section{Simulation tools to understand, evaluate and strengthen innovations on farms}

\author{
Éric Penot, Nadine Andrieu, Nathalie Cialdella and \\ PhilipPe Pedelahore
}

Summary. The evaluation of agricultural production systems with computerized 
tools makes it possible to analyse, design and support innovation at the farm level. We present here two experiences of using computerized tools in Africa: Olympe, in Madagascar, and Cikeda, in Burkina Faso. Olympe helped assess ex post the relative impact of adopting an innovation such as conservation agriculture on farm income. It also demonstrated its medium- and long-term benefit, through an ex ante analysis, by suggesting ways of stabilizing incomes. Cikeda allowed an ex post analysis of the performance of existing farms and an ex ante determination of new modalities of croplivestock integration in an approach to support these innovations amongst farmers. Since these tools are only intended to address a specific issue, they are likely to be eventually discarded; they may, however, be of value to advisory organizations if they are incorporated in these organizations' workflows.

The evaluation of agricultural production systems allows the study of the trade-offs and synergies between their different functions (production, income, food security, employment, preservation of landscapes, biodiversity, etc.) and the comparison of current systems in terms of the complex dimensions of sustainability (van Ittersum et al., 2008). This evaluation can also help identify the determinants of change in technical or organizational practices (Cialdella et al., 2009) or to determine the consequences of these changes in the short, medium or long term (Andrieu et al., 2015). The results of the evaluation can then be used to guide the decision making of farmers, agricultural advisers and policymakers wishing to analyse ex post or ex ante the effects of different options for change in the management of production systems or in the farming environment. Evaluations, whether ex post or ex ante, are at the heart of approaches for co-designing new production systems, which include shared diagnoses, the testing of new systems and the measurement of their performances (Duru et al., 2012; Le Gal et al., 2011). An ex ante evaluation essentially involves comparing virtual scenarios and identifying promising patterns, whereas an ex post evaluation involves drawing lessons from the performance of existing practices. The evaluation is a tool and an approach at the same time, and can be used to analyse, design and support farm-level innovation.

This evaluation can be based on qualitative or quantitative approaches using mathematical and/or computerized models. The line of research that has now developed around the use of computerized models of the functioning of farms was inspired by the analytical frameworks of the management sciences, initially focused on accounting and fiscal analysis, and by the analytical frameworks of the economic sciences, by combining the management of 
farms with the analysis of income formation (Penot, 2012). These computerized tools, and especially the simulation tools, help undertake an analysis that takes time into account (cropping season, a single year, or several years). They also allow a prospective analysis through the creation of scenarios to either estimate expected results or test the usefulness of certain changes.[56]

By focusing on specific technical or organizational changes at the farm scale, these approaches can be distinguished from other approaches to simulate accompaniment, such as Companion Modelling (Barreteau et al., 2003), whose primary goal is the coordination of actors around the management of a collective or common resource, or Mesmis (Manejo de recursos naturales incorporando Indicadores de Sustentabilidad) (Lopez-Ridaura et al., 2002), whose goal is to define, in a shared manner, the relevant criteria for evaluating the sustainability of agricultural activities of a given family or community.

In this chapter, we want to discuss the utility of computerized tools for both ex post and ex ante evaluations of innovations and changes in farms, and to support actors in innovation processes, by referring to two experiences of using computerized tools in Africa. The Olympe software package, which permits a step-by-step budgetary simulation, was used with farmers in the Lake Alaotra region of Madagascar (Penot, 2012), and Cikeda, a simulation tool to evaluate crop-livestock integration, was used in Burkina Faso (Andrieu et al., 2015; Sempore et al., 2015). The evaluations based on these tools, carried out in Madagascar and Burkina Faso respectively, are part of the dynamics of the participatory accompaniment of innovating actors.

In both cases, the farmers were involved in the construction of models and in discussion of computer outputs, through presentation sessions in focus groups (in Madagascar) or through exchanges amongst individuals (in Burkina Faso).

We will present and compare these two examples to show the utility and limitations of these types of quantitative simulation tools for evaluating technical and organizational innovations at the farm level. We will then propose methodological avenues to broaden their area of application. 


\section{W Olympe: a tool for budgetary simulation in a network of reference farms in Madagascar}

\section{Context and issues in the Lake Alaotra region}

Madagascar's Lake Alaotra region is a densely populated area, struggling to maintain long-term land fertility in hilly and rainfed areas. The main problems faced by farms here are heavy erosion and high soil fragility, significant variability in the amount of rainfall and the length of the rainy season, a lack of capital resulting in reduced use of agricultural inputs, inadequate mechanization for unirrigated rainfed agriculture, and difficulties in marketing. In order to understand the strategies of agricultural households, and then to be able to accompany them better in a transition towards a more sustainable agriculture, an annual monitoring of a network of reference farms (set of agricultural farms representative of the various agricultural situations and selected from a typology) was instituted to gauge the impact on farms of a development project (the BV-Lac or 'Basin-Watershed-Alaotra Lake'[57] project) whose goal was, among others, to promote conservation agriculture.

This annual monitoring had a twofold objective:

- estimate the impact on the results of the farms of the adoption of new farming techniques and practices proposed by the project;

- compare the results obtained with those of other potential scenarios.

The Olympe modelling tool was used for this purpose.

\section{Features and goals of the Olympe tool}

Olympe, developed by researchers from the French National Institute for Agricultural Research (INRA), the Mediterranean Agronomic Institute of Montpellier (IAMM) and the French Agricultural Research Centre for International Development (CIRAD), is a tool for farm budgetary modelling and simulation of the economic functioning of farms that takes their diverse activities and resources into account. It is capable of creating models of 
farming systems that are sufficiently detailed to allow an economic analysis of performances based on technical choices, types of production and labour management methods. Olympe simulates economic performance at the scale of a cropping or livestock system, or a product-processing sector, at the scale of the farm or of groups of farms. In addition to undertaking automated calculations (farm accounts, balance sheet, monthly cash flow, hours worked, labour calendar, records of animal entries and exits), Olympe can be used to create customized data output tables by selecting a set of calculated variables and by creating indicators that appear relevant. The tool includes a module for graphic presentations. It is capable of analysing ten-year data series and can compare farms according to different scenarios. Basic structural farm data are obtained through farm characterization surveys. Information is collected on production systems and technical itineraries adopted, on sources of agricultural and non-agricultural incomes, and on hours worked. Data is also collected on constraints on farms, strategies of farmers and the opportunities available to them. The modelling of farms, on the basis of the reference farm network, also relies on the availability of a plot-level database that was created from the monitoring of 3000 plots over the ten years of the BV-Lac project.

\section{Using the Olympe tool}

The network of reference farms, consisting initially of 55 farms, was set up in 2008. In 2011, it was reduced to 15 farms that were considered representative in order to carry out a prospective analysis focused on the likely effects of the adoption of conservation agriculture through an exploration of different possible scenarios. This network made it possible to measure the potential impact of the adoption of new practices proposed by the project (cropping systems in conservation agriculture), first at the level of the cropping systems and then at the farm level (Penot et al., 2015). The actors concerned by this mechanism included the surveyed farmers - regularly invited to sessions for the presentation of results -, the 60 technicians and engineers involved in the project (from the project team, consultancy firms and non-governmental organizations) - responsible for experimentation and extension activities -, and researchers from CIRAD and FOFIFA (National Centre for Applied Research on Rural Development, Madagascar). The presentations of the 
results, sometimes organized in the villages, made it possible not only to discuss the results but also to improve the modelling by taking the participants' observations into account and defining new simulations based on their proposals.

\section{Results of the Olympe tool}

The results showed that aside from a limited core of about 600 farmers who had fully adopted conservation agriculture techniques, a large number of farmers had partially adopted agroecological techniques and had thus achieved varying results that are yet to be really assessed. Although the techniques promoted in conservation agriculture ensure production over the long term and appear to maintain soil fertility, it is still the standard agricultural intensification (which uses significant amount of mineral and organic fertilizers for soil fertility) that provides the best yields, and thus the highest incomes. The quantification obtained by modelling with Olympe helped detail the farmers' costs and margins, and thus put into perspective the real impact of the adoption of conservation agriculture on the income of a farm using low levels of inputs. The impact is greater on production stability in the medium term. The prospective analysis also made it possible, by testing various possible technical innovations and theirs impact on the farms' economic results and by taking into account the variability existing between farms, to change the perception of the technicians of the development project on the technical choices they were proposing. Thus, new actions have been proposed by the project in terms of agricultural experimentation, technical proposals made to farmers, and training them. In a certain way, farmers were the first beneficiaries of these modelling activities since it was their realities and constraints that were taken into account, thus leading to modifications in the extension services on offer. Figure 16.1 illustrates this approach. 


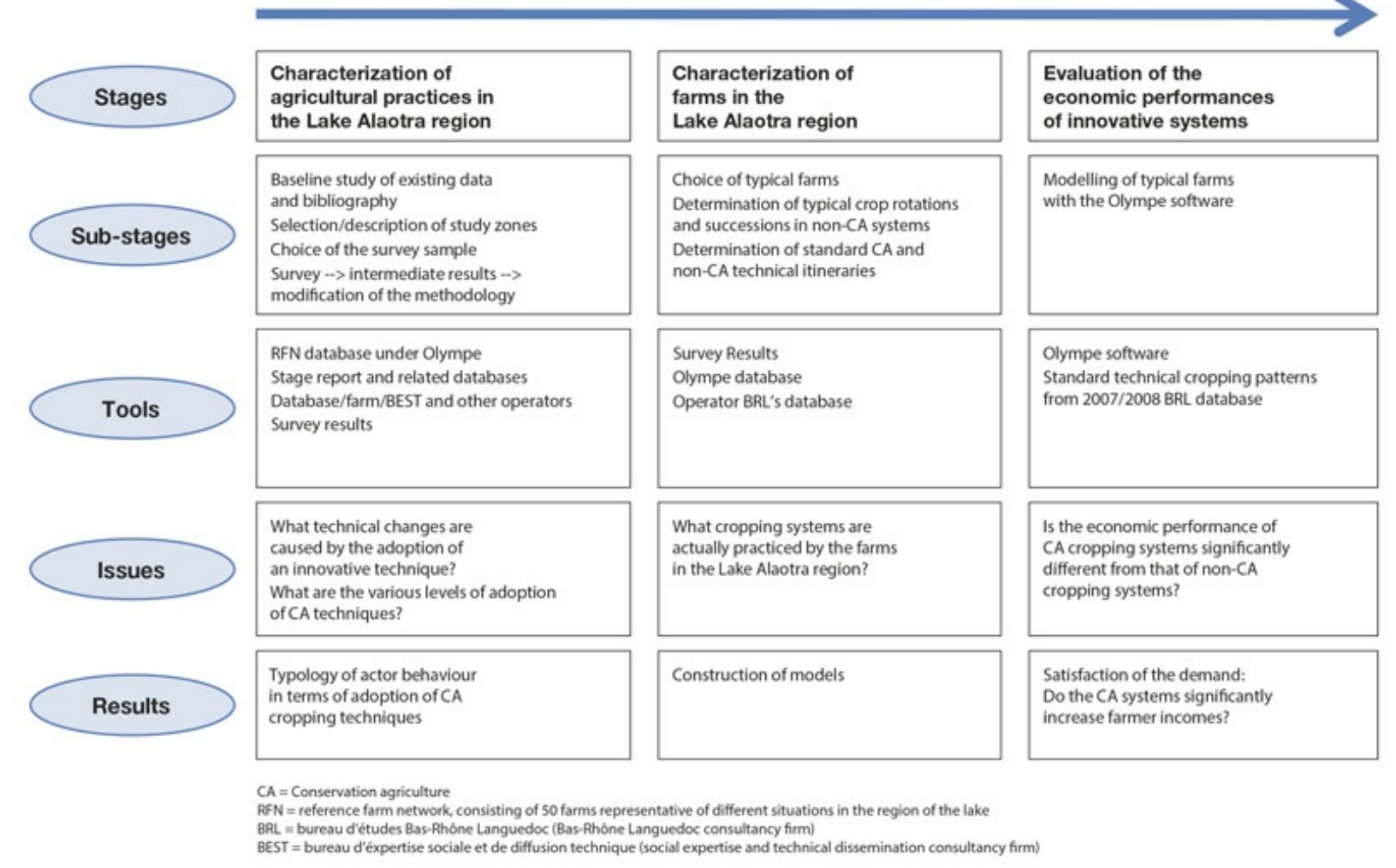

Figure 16.1. Methodological approach using Olympe in the Lake Alaotra region (Madagascar).

\section{Cikeda: a computerized tool for the co-design of mixed farming systems in Burkina Faso}

\section{Context and issues in western Burkina Faso}

Like other areas in sub-Saharan Africa, western Burkina Faso has experienced demographic growth and the settlement of its populations over the last 30 years. The upsurge in the clearing of rangeland to increase arable land and an increase in the same period of the size of cattle herds of both livestock herders and farmers, has led to friction between these two producer groups. One of the challenges faced by our research and development efforts within the framework of the collaboration between CIRAD and its research partners in Burkina Faso was to develop and implement new production systems with producers to find and strengthen complementarities between 
crop and livestock systems. These new systems include, for example, innovations based on the inclusion of fodder crops in cropping systems and on the use of crop residues. It was also a matter of updating the approaches for the co-design of production systems and for the accompaniment of producers. Tools to simulate farm operations were used to do so. We present here one of these tools, Cikeda (meaning 'farm' in Dioula), the manner in which it helped farmers who used it to make ex ante evaluations of the different scenarios of change they themselves had defined, and the effect the approach had on their knowledge and practices.

\section{Features and objectives of Cikeda}

Cikeda aims to strengthen approaches for co-designing production systems within the framework of a participatory approach involving the researcher, the farmer and a technician (deputed from the agriculture or animal resources ministries). This tool helps calculate the effect of different technical and organizational alternatives on resource flows (residues, organic manure, cereals) at the farm level, in terms of balances of fodder, mineral and cereals, as well as of income (Andrieu et al., 2012). Cikeda was developed on the basis of surveys on the functioning of farms, as well as several focus groups with farmers between 2008 and 2013, so that its inputs and outputs could be defined and farm specificities better taken into account. It has been used to help producers compare the performance of different strategic and tactical choices and, in particular, those of different scenarios for crop-livestock integration (Sempore et al., 2016).

\section{Using Cikeda}

Cikeda was used by technicians and researchers to support the decisionmaking process of 13 producers representative of the three kinds of farmers (cultivators, livestock farmers, agropastoralists[58]) found in Koumbia and Kourouma villages, in western Burkina Faso. Different interactive scenarios, i.e. scenarios that were explained and discussed with the producers, were simulated: the reference scenario, or scenario 0 , corresponding to the existing characteristics of each farm and its practices, and different prospective 
scenarios in which strategic and tactical changes were introduced by the producer, in interaction with a researcher (Sempore et al., 2015; 2016) or a technician (Andrieu et al., 2012), based on the results obtained in previous scenarios. The innovations evaluated were diverse and depended on the farm's strategic orientation. These included, for instance, compost production by cultivators and agropastoralists, the introduction of fodder crops and storage of crop residues by agropastoralists and livestock farmers, or the introduction of a beef fattening unit by these same producers. Surveys were then conducted with producers who had used Cikeda to assess their perception of the tool, the effect of the approach on their knowledge and practices concerning crop-livestock integration.

\section{Results obtained using Cikeda}

The use of Cikeda allowed producers to systemically and prospectively evaluate different innovations for their cropping and livestock systems, before testing them on farm, and to select options that are useful and feasible in the short term. The co-design and simulation of alternative solutions and strategies led to a rapid change in the management of soil fertility and of animal feed for the 13 producers who tested the approach between 2009 and 2013 (six producers in Koumbia, seven in Kourouma). They undertook these changes mainly because of their improved knowledge and understanding of the flows of fodder biomass and fertilizers between cropping and livestock systems on their farms.

The use of the Cikeda to evaluate different scenarios for the next cropping season, with six producers between 2011 and 2012, made them aware of the need to better manage organic manure and livestock feed using fodder. Thus, one of the agropastoralists who used the tool understood the need to prepare for the fattening process, not, as he tended to do, at the end of the harvest season, but before it even started, in order to determine the fodder plot size and the reserves of residues to maintain. Cultivators noted an improvement in their knowledge of fertilizer production and crop fertilization, as also in their ability to estimate the amount of residue to harvest to meet the needs of their draft animals and limit their dependence on cotton cake. Reflection encouraged by discussions of the scenarios resulted in changes in practices, 
in particular in an increase in the amount of organic fertilizer produced on the farm as compared to the initial practices.

This case study shows the value of an evaluation based on a computerized tool, used in an approach for co-designing, with the farmer, production systems using scenarios incorporating and comparing innovations that promote or optimize the crop-livestock relationship. However, one limitation of the approach lies in the time required to be devoted to each farm, which prevented the transfer of the Cikeda tool to advisory entities, even though their technicians were involved in its design and utilization phases. Reflection is needed on how this kind of tool can be used to train technicians so that they can apprehend the complexity of farms and are able to conduct the necessary dialogue with the farmers to improve production systems.

\section{Lessons from these two case studies}

\section{Advantages and limitations of simulation approaches and tools}

These two case studies illustrate two approaches for the quantitative evaluation of farm operations in Madagascar and Burkina Faso to support agricultural innovations (conservation agriculture, in the first case, and management of crop residues and fodder crops for animal feed and manure production in the second). These approaches use computer software to provide quantified information on the advantages and disadvantages of adopting a technical innovation (conservation agriculture) or a set of techniques and management modalities of a farm's various production units (crop-livestock integration). This evaluation concerns the existing situation of the farms (ex post evaluation) as also - and this represents the value addition of these approaches - the discussion of possibilities of change with the actors and their effects on farm performance.

In both cases, the tools used are based on a detailed knowledge of the farming environment and the ground realities of the farmers. Variables are therefore chosen, as are processes to simulate, from a shared vision with the actors 
involved of the situation and the agricultural problems to be addressed. These tools are complex because they incorporate a systemic representation of different farm components, and possibly of the household (notion of production systems and activities). In fact, they simulate economic flows (money, labour) and, in the case of Cikeda, material flows (biomass, nutrients) between the different compartments of the farm. They generate annual, economic (Olympe) or agroeconomic (Cikeda) reports, which can illustrate and compare the impacts of technical or organizational changes at the farm level. Passage of time is taken into account in Olympe through the looping of the simulation outputs for a given year $n$ into the inputs of the model for the year $n+1$. In Cikeda, the changes are simulated at the seasonal scale (dry season and rainy season) and aggregated over the year. The structural evolutions of the farms (over a period of more than ten years) are not simulated but can, however, be input into the model by the user, if they correspond to a desired scenario. It is, however, difficult to analyse the processes of socio-economic differentiation between farms using these models.

In general, the use of these tools by the practitioners (farmers and technicians) within the framework of approaches to co-design innovation is complementary to on-farm experiments. Modelling can be used to test a wide variety of scenarios for introducing innovations in farms in order to narrow the options to the most promising innovations, whose performance can subsequently be evaluated through experimentation.

The potentially normative nature of this type of tool requires a considered and contextualized approach to their use. The results of computer-generated evaluations should not be considered in absolute terms; they should instead be used as a basis for discussions with the actors concerned to evaluate $e x$ post or ex ante the adoption of innovations, or to evaluate changes in farm trajectories.

\section{Appropriation of these simulation tools by the actors}

The tools were mainly designed to test new production systems and to 
accompany farmers. However, they were also used to train technicians, project engineers and students. Thus, students of the Polytechnic University of Bobo-Dioulasso in Burkina Faso used Cikeda in their work. Olympe helped train the BV-Lac project team and students from local and French universities associated with the project.

However, these tools were not retained by the development partners (nongovernmental organizations, producer organizations, etc.) when research support ended. Even though Cikeda was tested with technicians of the agriculture and animal resources ministries, the research effort was focused mainly on changes in knowledge and practices that the tool could help bring about within an approach for the co-design of innovations, and much less on the conditions of using the tool within advisory structures. Olympe was used, with the support of the research community, as part of another project (BVPISEHP [59]) in Madagascar between 2006 and 2013, based on four reference farm networks, but its use was discontinued when the projects ended, partly due to the structural weaknesses of Malagasy advisory organizations.

Indeed, advisory organizations in the countries of the Global South find it very difficult to appropriate these complex tools to support farmers within a framework of group advice (common in Africa) or of the individual monitoring of farms (common in Europe, the United States and Australia). In the case of Olympe, however, an experiment showed that its use for individual advice was easier and more relevant for large farms, even though these tools were not specially created for this type of farm. Cikeda has not been tested with farmer groups. However, in addition to this distinction between individual and group advice, the two experiments did not seek to evaluate the costs to advisory structures of using this type of tools, in terms of technician training, acquisition of computer hardware or reorganizations of the workflow of advisers.

Finally, two options are possible for the appropriation of these tools by nonresearch entities. We could assume and admit that the structure and use of the tools are project-specific. They depend on the context in which they are built, the nature of the innovations evaluated, as also the skills of the designers. Such an assumption implies that the tool could be discarded once the specific goals of the project have been met. This is the case in our two examples, as it 
appears that the tools were primarily designed to address specific research or project issues. Or we could wish for the tool to be more generally useful, beyond addressing the specific issues raised by researchers or the project, especially for advisory organizations or regional observatories - but such an intention would require the tools to be redesigned. An increased participation by development actors would be needed in the design of such a tool, so that, on the one hand, it is more adapted to the actors' need and, on the other, it may eventually be appropriated by these actors, by becoming part of the workflow of the organizations that are its intended users.

\section{Conclusion: the use of simulation in the evaluation of innovation processes}

Through two case studies, this chapter shows how the use of simulation tools can effectively contribute to the co-design and evaluation of innovations on farms. In Madagascar, the use of Olympe has allowed, by means of an ex post analysis, to put the real impact of the adoption of an innovation such as conservation agriculture into perspective, especially in terms of farm income. It has also demonstrated its medium- and long-term benefit, through an ex ante analysis, in terms of stabilization of farm income. The use of Cikeda in Burkina Faso allowed an ex post analysis of the performance of existing farms and an ex ante assessment of new modalities of crop-livestock integration. Its use also helped gauge its value as part of an approach to support these innovations with farmers. However, we want to emphasize that evaluations through simulation should always be combined with methods of qualitative evaluation of farm trajectories in order to better take into account the interactions between farms and their environment. It also appears important to undertake an improved analysis of the conditions conducive to the co-design of these tools with and their use by advisory organizations, in order to improve the advice they provide by incorporating the complexity of the farm.

\section{Bibliography}

Andrieu N., Descheemaeker K., Sanou T., Chia E., 2015. Effects of technical 
interventions on flexibility of farming systems in Burkina Faso: Lessons for the design of innovations in West Africa. Agricultural Systems, 136, 125-137.

Andrieu N., Dugué P., Le Gal P.-Y., Rueff M., Schaller N., Sempore A., 2012. Validating a whole farm modelling with stakeholders: Evidence from a West African case. Journal of Agricultural Science, 4, 159-173.

Barreteau O., Antona M., D’Aquino P., Aubert S., Boissau S., Bousquet F., Daré W., Etienne M., Le Page C., Mathevet R., Trébuil G., Weber J., 2003. Our companion modelling approach. Journal of Artificial Societies and Social Simulation, 6(1), <http://jasss.soc.surrey.ac.uk/6/2/1.html tr> (retrieved 11 August 2018).

Cialdella N., Dobremez L., Madelrieux S., 2009. Livestock farming systems in urban mountain regions: differentiated paths to remain in time. Outlook on Agriculture, 38(2), 127-135.

Duru M., Felten, B., Theau J.-P., Martin G., 2012. A modelling and participatory approach for enhancing learning about adaptation of grasslandbased livestock systems to climate change. Regional Environmental Change, $12,739-750$.

Le Gal P.-Y., Dugué P., Faure G., Novak S., 2011. How does research address the design of innovative agricultural production systems at the farm level? A review. Agricultural Systems, 104, 714-728.

López-Ridaura S., Masera O., Astier M., 2002. Evaluating the sustainability of complex socioenvironmental systems. The MESMIS framework. Ecological Indicators, 2(1), 135-148.

Penot E., 2012. Exploitations agricoles, stratégies paysannes et politiques publiques. Les apports du modèle Olympe. Éditions Quæ, Versailles, 350 p.

Penot E., Domas R., Fabre J., Poletti S., Macdowall C., Dugué P., Le Gal P.Y., 2015. Le technicien propose, le paysan dispose. Le cas de l'adoption des systèmes de culture sous couverture végétale au lac Alaotra, Madagascar. Cahiers Agriculture, 24 , 84-92, $<$ http://agritrop.cirad.fr/575868/1/document_575868.pdf $>$ (retrieved 11 
August 2018).

Sempore A.W., Andrieu N., Le Gal P.-Y., Nacro H.B., Sedogo M.P., 2016. Supporting better crop-livestock integration on small-scale West African farms: a simulation based approach. Agroecology and Sustainable Food Systems, 40(1), 3-23.

Sempore A.W., Andrieu N., Nacro H.B., Sedogo M.P., Le Gal P.-Y., 2015. Relevancy and role of whole-farm models in supporting smallholder farmers in planning their agricultural season. Environmental Modelling \& Software, $68,147-155$

van Ittersum M.K., Ewert F., Heckelei T., Wery J., Olsson J.A., Andersen E., Bezlepkina I., Brouwer F., Donatelli M., Flichman G., Olsson L., Rizzoli A.E., van der Wal T., Wien J.E., Wolf J., 2008. Integrated assessment of agricultural systems - A component-based framework for the European Union (SEAMLESS). Agricultural Systems, 96, 150-165.

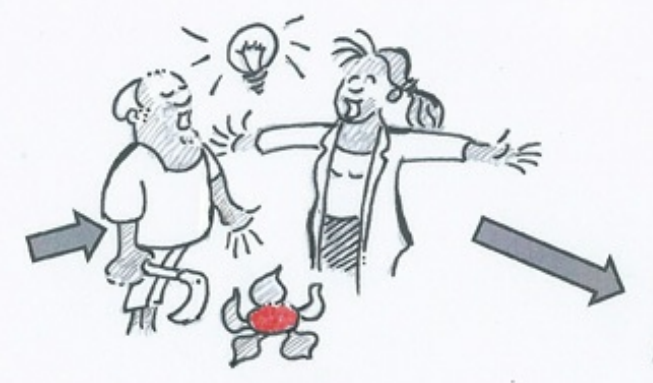

DECOUNRIR...

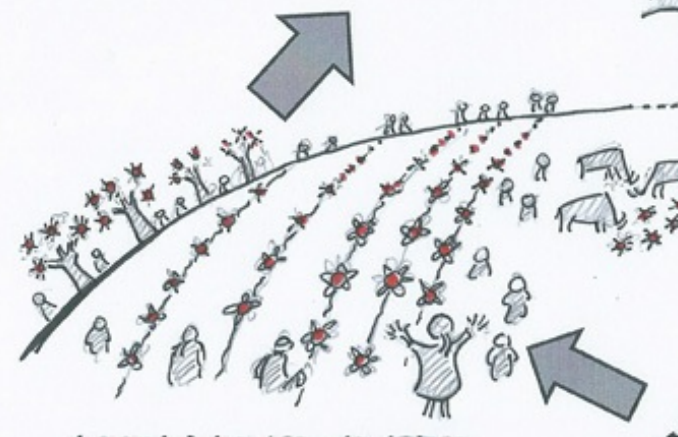

ACCOMPAGNER, ADAPTER.....

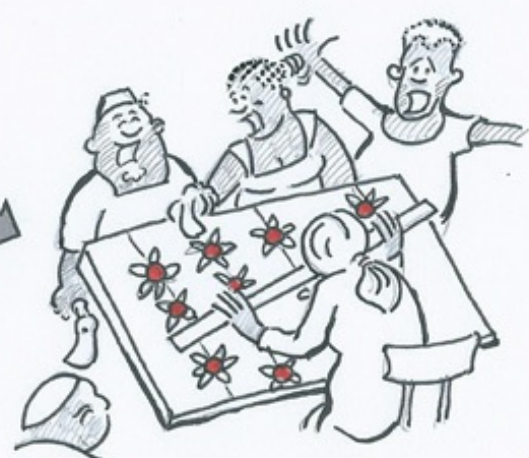

MOBILISER, S'ORCANISER... 


\section{Spiral of innovation @ Eric Vall}

35 Responsible Research and Innovation

(http://www.horizon2020.gouv.fr/cid84192/recherche-innovation-responsable-versionactualisee-de-la-declaration-de-rome.html ¿*)

$36 \mathrm{~A}$ responsible innovation can be defined as one in which the actors, in complete transparency with society, take into account the possible consequences of its process and its products, 'while keeping acceptability (ethics), sustainability and social desirability in mind' (Von Schomberg, 2011).

37Projects for agricultural and rural development financed by the French Ministry of Agriculture.

38It is an action-research effort linked from its inception to a goal of innovation.

39This association was formed in September 2015 at the initiative of Jocelyne Porcher and Stéphane Dinard, a livestock farmer in Dordogne.

$40 \quad$ https://fr-fr.facebook.com/Quand-labattoir-vient-\%C3\%A0-la-ferme-

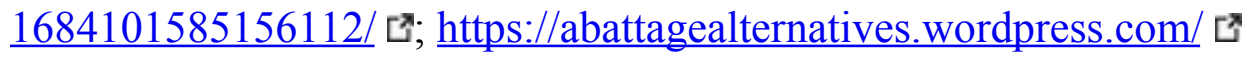

41As of April 2018.

42Because of its success, the 'When the abattoir comes to the farm' collective acquired the status of an association in September 2017, which allows it to receive donations and funding from public and private entities.

43The Parliamentary Committee on slaughtering conditions of animals bred for food, chaired by Mr Olivier Falorni, questioned Ms Jocelyne Porcher (National Institute for Agricultural Research) and Mr Stéphane Dinard (farmer) on 16 June 2016.

44Hearing of 16 June 2016, by the French Parliamentary Committee on slaughtering conditions of animals bred for food.

45From its offices in Switzerland, Germany, Austria and Belgium (Brussels), FiBL conducts research and provides support to extension efforts on organic farming and sustainable development.

46 http://impress-impact-recherche.cirad.fr ${ }^{\star}$

47This innovation was led by Claire Cerdan, of the 'Innovation' Joint Research Unit (Montpellier, France), and by Universidade Federal de Santa Catarina (UFSC), Empresa de Pesquisa Agropecuária e Extensão Rural de Santa Catarina (Epagri) and producers belonging to the ProGoethe association, Brazil.

48 http://www.impresa-project.eu ${ }^{\top}$

49The workshop was attended by two researchers from INRA and three from the French Rice Centre (CFR), two representatives from SARL Thomas (a company that sources and markets organic rice from Camargue) and one from Biocamargue (a sourcing company that processes and adds value to the organic rice from Camargue), a moderator, a facilitator, seven farmers, and two assistants.

$50 \mathrm{We}$ consider impacts to be the direct effects of practices on the state of goods, people and resources. The effects are reorganizations within the system (which may affect different subsystems) whose nature and eventual consequences on the objects mentioned 
above are initially difficult to gauge.

$51 \mathrm{~A}$ criterion is a relatively broad category for judging the state of a dimension of the analysed system (for example, indebtedness, to assess the economic dimension of a farm's sustainability). In practical terms, a criterion is measured by one or more indicators.

52In fact, IDEA is turning out to have a much more universal appeal, since the method has been widely used and adapted in many parts of the world (Tunisia, Morocco, Canada, Argentina, Réunion, etc.).

53A criterion can be evaluated using one or more indicators. Similarly, the indicator is often composite in nature and is then the result of the measurement of several subindicators. We thus obtain a hierarchical tree but the manner of aggregating the results obtained at each level has to be determined.

54Methods of sale that do not involve intermediaries or, at the most, only one between the producer and the consumer (Ministry of Agriculture, Food and Fisheries, 2009). 55The acronym Glamur stands for Global and Local food chain Assessment: a MUltidimensional performance-based approach.

56There are several tools for prospective analysis. They include linear programming, to define the technical optimums, methods centred on decisional rules, such as MATA (Multilevel Analysis Tool for Agriculture), DEXi (Decision EXpert for Education) and MASC (Multi-attribute Assessment of the Sustainability of Cropping systems), and simulation, with or without a decision-making process.

57In French: Bassin-Versant-Lac.

58While a cultivator may own a few draft animals, most of the animals owned by agropastoralists are for fattening.

59Watersheds and irrigated perimeters in the southeast and the highlands. 


\section{Afterword \\ What types of innovation for sustainable agriculture?}

The food we eat and the way we produce it are signs of our relationship to the world, to spaces and to others. Any reflection on innovations in the agriculture and food sectors thus compels us to look at the links between these innovations and our relationship to the world. And herein lies the main strength of this book: agricultural and food innovations are apprehended through the societal debates of which they are part, be it debates on animal welfare, biodiversity preservation, or the access to a balanced diet for all.

There is no easy solution to the problem of feeding a growing population given our limited natural resources - some of which, such as copper and phosphate, are already relatively depleted. How can we feed an extra two billion people by 2050 without breaching the physical limits of our planet? As it is, 815 million people in the world are today suffering from hunger, according to the Food and Agriculture Organization. The availability of a healthy balanced diet for all is nowhere near ensured, especially given the brutal disruptions that climate change is bound to inflict on agriculture, starting with its impact on soil fertility. According to the latest IPCC (Intergovernmental Panel on Climate Change) report, wheat yields declined globally by just over 5\% between 1980 and 2010 due to the first observable climate-driven disruptions. If unchecked, climate change is expected to reduce median agricultural yields by $2 \%$ every decade. And yet, to meet the world's growing demand for food, production needs to increase by $14 \%$ per decade. The news is no better on the biodiversity front: we are witnessing a vast migration of species, from the equator to the poles, from the plains to the mountaintops, with their move towards more favourable climes now averaging $6 \mathrm{~km}$ a year across the surface of the planet. A stroll for bipeds such as ourselves, but a momentous challenge for plant cover!

Agriculture is not only a source of income for 2.5 billion people and major 
consumer of natural resources such as water and phosphate, but also a victim of climate change and contributor to global warming (24\% of greenhouse gas emissions are of agricultural origin, if we include land-use change). As such, the sector plays a decisive role in all the major transitions: ecological, of course, but also social and demographic, political, energy, and even digital. What is worse, agriculture mainly relies on the small peasantry that often survives close to the threshold of extreme poverty. The paradox now pervading our contemporary societies is that the social value given to work seems inversely proportional to the latter's contribution to the common good. In large cities, in the event of a global disaster, one of the jobs that needs to be ensured at all costs is not that of a footballer or business lawyer, but the work of the operators of sewage treatment plants. Without them, no city can survive beyond a few weeks. Mutatis mutandis, the same thing applies at a global scale: without the small farmers in the Mekong Delta or the Gulf of Guinea, the overwhelming majority of humanity would run out of food within a matter of months.

Agricultural and food innovation is therefore decisive for the transformation of our food systems and the transition of our economies towards societies that are carbon-neutral, fair, and resilient to the seemingly unavoidable collapse of natural ecosystems.

\section{What technological avenues?}

As the book notes, the choice of technological avenues to follow in order to ensure that agricultural and food innovations contribute to the ecological transition is a source of lively debate. Contentious arguments flow back and forth between the proponents of the technical intensification of agriculture, the promoters of ecological intensification, and the followers of agroecological practices, organic farming and peasant agriculture, among others. These debates reflect the different possible avenues towards sustainable agriculture that are open to us. They clearly represent real societal choices, as important as the choice of the energy mix that will characterize our economies in the 2030s.

Until the 1990s, the agricultural models advocated by the international donor 
community for the countries of the Global South were predominantly those of the Green Revolution. The trend was to standardize farming practices to increase yields, with farmers rarely being seen as vectors of innovation. However, the potential of the often-frugal peasant inventiveness is today gaining more recognition. On African cocoa farms, for example, chicken droppings are beginning to be used to maintain soil fertility and avoid the expense of synthetic fertilizers, which are greenhouse gas emitters. Farmer innovations can also be a source of inspiration for researchers working on the agroecological transition of African cocoa farming. In Cameroon and Côte d'Ivoire, we are witnessing the rediscovery or continued use of complex agroforestry systems in which the cocoa tree is associated with other perennial, forest and fruit species offering multiple uses. In Ghana, a simpler form of agroforestry is being used. Planted around the cocoa tree are orange trees, teak, or other species that combine three properties: income or income expectancy, a potential ecological service such as providing windbreaks, and better land demarcation.

Agricultural and food innovations take many forms and affect the entire value chain, from production to consumption. They can help bypass the productivist model of the Green Revolution and encourage an agriculture adapted to climate change and the biodiversity collapse already underway. The survival of agriculture in areas especially vulnerable to ecological disruptions depends on the implementation of technical innovations. This is the case, for example, in the Sahel, where increased rainfall variability can endanger the food security of populations whose demographic transition is not yet complete. The use of zaï (half-moon planting pits for microcatchment) could be extended to help maintain soil fertility, use rainwater runoff, and combat drought. Similarly, in a warmer future climate, some traditional varieties of cereal would actually be less vulnerable than 'improved' varieties thanks to their photoperiodic characteristics.

Digital advances and artificial intelligence are expanding the possibilities of innovation in sustainable agriculture across all of its three dimensions: social, environmental and economic. The collection of numerous data, whether through satellite imagery, sensors installed directly on farmers' plots, or via digital platforms, provides valuable information on the state of the soil, the weather, the availability of products, or the location of consumers. This opens 
countless opportunities for improved management across the sector, from production to distribution. The 2017 Digital Africa award, funded by the French Development Agency and the French Public Investment Bank, has rewarded two start-ups in the agricultural sector whose activities are firmly rooted in the new digital age. The first, e-Tumba, provides a data analysis solution for plots of land, simulating crop development, predicting yields, and offering individual plot-level advice. The second, Farm Drive, has developed a risk analysis model of small farmers' activity using geographic, biological, and satellite imagery data. Multiple digital applications are now available for agricultural and food activities and often promote networking, as for example, the 'app' that connects retailers who have unsold products to consumers wanting to buy low-cost food.

Upstream of the agricultural sector itself, the Watex process for exploring deep aquifer sources, developed by engineer Alain Gachet, could help identify underground drinking water resources that have hitherto remained unexploited. In a world where the water cycle is already severely disrupted and will undoubtedly be more so tomorrow, the good news is that there is much more drinking water underground than on the planet's surface. But its reasoned exploitation presupposes a certain number of drastic conditions. First and most importantly, humanity must use the already available water far more judiciously. The losses, both in agriculture and in the end use of water for urban purposes, are colossal and the scope for progress is therefore huge. Second, the issue of recycling and waste-water treatment must become a priority, otherwise any additional influx of water to meet a growing demand could have disastrous health effects if the appropriate water infrastructure is lacking. Third, even if we discover the location of aquifer sources, we still need to be able to access them. Pumping water from a water table 400 metres deep requires infrastructure similar to the equipment enabling the oil industry to extract fossil hydrocarbons. The costs can be significant and must be calculated ex ante. Finally, we must acknowledge that this subsoil water is the last 'clean' water that humanity has. After all, we do not have another blue planet.

Yet, while technical innovation in the agriculture and food sectors is necessary to meet agricultural and food challenges, it can also pose a threat. The use of neonicotinoids in agriculture is a good example of this duality. 
Introduced in the 1990s to control crop pests, they have also proved destructive to pollinators. It has taken more than 20 years for the European Union to ban the use of three neonicotinoids for field crops, and this after numerous studies had shown how toxic these products are to bees. This example underscores how the quest for private short-term profit can trump the general good, since it is now clear that the corrupt campaigns of misinformation (also involving reputable scientists) that helped maintain a climate of collective doubt as to the toxicity of these insecticides were funded by industrialists with a vested interest in seeing the ban on these products delayed for as long as possible. Obviously, any evaluation of the impacts of an innovation cannot abide by the yardstick of the expected additional yield made possible by the innovation, and even less by that of the eventual additional income it may create.

\section{Financial environment}

Agricultural technical innovation and the possibilities opened up by digital technology are all well and good, but genuine creativity is essential for better sustainable agricultural management. In the area of financing, I can cite the example of the 'warrantage' [60] credit system, whereby a farmer is able to obtain a rural loan by putting up part of his production as collateral. Of course, this type of mechanism must be used with extreme caution given the risks it incurs to the said farmer if he is unable to repay the loan. The problems of moral hazard are legion in this domain, as they are in the area of microcredit in particular. The mismanagement of microcredit schemes has already led to tragedies, the numerous incidents of farmer suicides in India being one example among many.

But building a financial environment conducive to sustainable global agriculture also requires international regulation of the financial derivatives markets for agricultural commodities. As we know, the price of these basic commodities - on which not only the survival of small farmers but also the availability of food for all of humanity depends - is no longer determined in the short term by the balance between the supply and demand of agricultural products, but by capital flows into and out of derivative instruments that have these products as their underlying assets, in particular forward delivery 
contracts. The financial value of the derivative markets for such products is often several tens of times greater than the spot market value of the commodity itself. And the portfolio strategies that play out are mainly driven by speculative forces that are largely disconnected from the interests of farmers and consumers alike. The World Trade Organization is helpless in the face of this reality, as financial markets remain outside its ambit. It is thus crucially important to bolster the regulation of international financial derivatives markets for agricultural products. The same problem obviously applies to all derivative assets, most urgently to those whose underlying assets are energy products as vital as oil. The stark difference separating these two markets is that the oil sector has substantial lobbying power over financial regulators - the peasantry in the Global South does not.

\section{Biodiversity and the commons}

The impact of innovation on biodiversity, especially on common species, is often poorly understood. So-called 'common' biodiversity is often overlooked in assessing the impacts of technical innovations, even though it can fulfil important functions in the ecosystem or landscape. Common species thus play a vital role in maintaining all biodiversity, be it directly (trees that provide micro-habitats for insects and cavicolous fauna, for example) or indirectly (interactions of predation or pollination). This interdependence between species has been highlighted by the recent work of the French National Museum of Natural History and the French National Centre for Scientific Research (CNRS), which report the disappearance of one-third of bird populations in the French countryside in the space of 15 years.

How can the genetic heritage of flora and fauna be preserved? The genetic diversity of peasant seed and plant varieties is the result of individual and collective innovation over the long term. It promotes the resilience of animal and plant populations to changing ecological conditions. In Senegal, for instance, some farmers in the groundnut basin have recently reintroduced long-cycle millet varieties that were abandoned during the droughts of the 1970s in order to benefit from the current rains. But genetic diversity is being undermined by monocultures. A 2011 study published by the Foundation for 
Research on Biodiversity on indicators used to monitor the genetic diversity of cultivated plants highlights, for example, the genetic and spatial homogenization of a species widely cultivated in France: soft wheat. The Foundation is alarmed by the growing vulnerability of wheat crops in the face of current and future environmental changes (pathogens, droughts, sustainable agricultural practices, etc.). In the intensive agriculture model, farmers no longer maintain plant genetic diversity in their fields. Even as we await the invention of models able to safeguard agricultural biodiversity more practically than the 'refrigerators' of research centres and the world-famous seed vault in Norway - which, in any case, are unable to preserve every agricultural species -, we urgently need to reflect on ways of safeguarding biodiversity in our fields.

One possible path forward would be to treat the genetic heritage of plants as a form of 'common' property around which one or more communities could be built to preserve this heritage. We have seen, for example, the formation of commons in some countries of the Global South for the conservation of peasant varieties that are absent from, yet complement, the selection of pure seeds found in national catalogues. More generally, managing natural resources as commons can constitute a third mode of appropriation, midway between privatization and nationalization, more likely to ensure that the planet remains hospitable to our human presence. Numerous such examples exist for water resources: in Jordan, Tunisia, Bolivia, and the Democratic Republic of Congo, communities have created and implemented their own rules for managing this resource, be it groundwater withdrawal or water access services. Agriculture and the food sector would certainly benefit from being viewed and organized as commons. As would money or work, for example. But such a transition would be a societal project of some proportion!

As for institutional innovation, the creation of the Associations for the Maintenance of Peasant Agriculture (Amap) in the 1990s in Europe has proved to be an unprecedented success. In France, according to the interregional Amap movement, 2,000 associations of this type were identified in 2015. Finally, innovations in the area of labelling also deserve mention, particularly the introduction in the 1990s of eco-labels, often referred to as 'voluntary sustainability standards', which rely on the willingness of some 
members of society to pay more in order to encourage others to adopt more sustainable production methods. In 2012, it was estimated that $40 \%$ of the traded coffee and $22 \%$ of cocoa were eco-labelled.

As the book emphasizes, a supportive institutional and legal environment is crucial to the emergence and dissemination of innovations in civil society and small enterprises. In this respect, support services for farmers play a key role. Contrary to what a proponent of libertarian thought might suggest, the State still has a major role to play in fostering the emergence of institutional innovations that enable humans to structure their relationship to the world they share with other living things. But, as the example of neonicotinoids reminds us, it is also up to the State to regulate the use of innovations that are detrimental to the collective interest - provided, of course, that the State manages to free itself from the regulatory 'prison' in which the private financialization of Global North societies sometimes keeps it confined.

In our era of the 'capitalocene', when the activities of the top decile of the most affluent humans (responsible for $50 \%$ of greenhouse gas emissions) contribute massively to the ongoing destruction of the terrestrial ecosystem, it is our responsibility to promote innovations that will facilitate the advent of ecological and social transitions to a more just and sustainable common world.

GaËl Giraud

Chief Economist at AFD; Director of Research at CNRS; Professor at École des Ponts ParisTech; Director at Chair Energy \& Prosperity

60 Warrantage, a French word commonly used in West Africa, denotes the inventory credit system (normally called the warehouse receipt system, or WRS, in English). 


\section{List of authors}

Nadine Andrieu, CIAT Km 17, Recta Cali-Palmira, Valle Del Cauca, Cali, Colombia, nadine.andrieu@,cirad.fr $ᄍ$

Jean-Marc Barbier, Inra, La Gaillarde, B27, 2 place Pierre Viala, 34000 Montpellier, France, jean-marc.barbier@inra.fr $₫$

François Boucher, IICA, calle San Francisco 1514, 03200, Mexico City, Mexico, fymboucher@yahoo.com $₫$

François Bousquet, Cirad, TA C-47/F, Campus international de Baillarguet, 34398 Montpellier Cedex 5, France, francois.bousquet@cirad.fr $\$

Bernard Bridier, Cirad, TA C-85/15, 73 rue Jean-François Breton, 34398 Montpellier Cedex 5, France, bernard.bridier@cirad.fr $\$

Hélène Brives, Isara Lyon, 23 rue Baldassini, 69364 Lyon Cedex 07, France, hbrives@isara.fr «

Claire Cerdan, Cirad, TA C-85/15, 73 rue Jean-François Breton, 34398 Montpellier Cedex 5, France, claire.cerdan@cirad.fr $₫$

Didier Chabrol, Le Cezanne A 603, avenue Pont Trinquat, 34070 Montpellier, France, didier.chabrol@ccirad.fr «

Eduardo Chia, Inra, La Gaillarde, B27, 2 place Pierre Viala, 34000 Montpellier, France, eduardo.chia@inra.fr $₫$

Yuna Chiffoleau, Inra, La Gaillarde, B27, 2 place Pierre Viala, 34000 Montpellier, France, yuna.chiffoleau@inra.fr $₫$

Nathalie Cialdella, Embrapa Amazônia Oriental, Travessa Doutor Enéas Pinheiro, s/n, Marco, Belém, PA, 66095-903, Brazil, nathalie.cialdella@cirad.fr $₫$ 
Camille Clément, Inra, La Gaillarde, B27, 2 place Pierre Viala, 34000 Montpellier, France, camilleleilaclement@gmail.com $\$

Jean-Paul Danflous, Station de Bassin Plat, BP 180, 97455 Saint-Pierre Cedex, Réunion, France, jean-paul.danflous@cirad.fr $\$

Stéphane de Tourdonnet, IRC, Lavalette, 1101 avenue Agropolis, BP 5098, 34093 Montpellier Cedex 05, France, stephane.de-tourdonnet@supagro.fr $₫$

Sylvestre Delmotte, $14763^{\mathrm{e}}$ avenue, Quebec, G1L2Y2, Canada, sylvestre@sylvestredelmotte.ca $₫$

Agathe Devaux-Spatarakis, 5 bis rue Martel, 75010 Paris, France, adevaux@quadrant-conseil.fr $\ltimes$

Marie-Laure Duffaud Prévost, Cermosem, Le Pradel, 07170 Mirabel, France, ml.duffaud.prevost@gmail.com $\ltimes$

Patrick Dugué, Cirad, TA C-85/15, 73 rue Jean-François Breton, 34398 Montpellier Cedex 5, France, patrick.dugue@,cirad.fr \ᄍ

Michel Dulcire, 14 impasse Marjolaine, 34830 Clapiers, France, michel.dulcire@,cirad.fr $ᄍ$

Guy Faure, Cirad, TA C-85/15, 73 rue Jean-François Breton, 34398 Montpellier Cedex 5, France, guy.faure@cirad.fr ㅉ

Thierry Ferré, Cirad, TA C-85/15, 73 rue Jean-François Breton, 34398 Montpellier Cedex 5, France, thierry.ferre@cirad.fr \

Stéphane Fournier, IRC, Lavalette, 1101 avenue Agropolis, BP 5098, 34093 Montpellier Cedex 5, France, stephane.fournier@supagro.fr \ᄍ

Pierre Gasselin, Inra, La Gaillarde, B27, 2 place Pierre Viala, 34000 Montpellier, France, pierre.gasselin@inra.fr $₫$

Gaël Giraud, French Development Agency, 5 rue Roland Barthes, 75598 Paris Cedex 12, France, giraudg@afd.fr $₫$ 
Frédéric Goulet, Cirad, Joint Research Unit 'Innovation and Development in Agriculture and Food', CPDA-UFRRJ, CEP 20071-003 Rio de Janeiro, Brazil, frederic.goulet@,cirad.fr $₫$

Nabil Hasnaoui Amri, Montpellier Méditerranée Métropole, 50 place Zeus, BP 9531, 34000 Montpellier, France, nabil.hasnaoui@gmail.com ㅉ

Michel Havard, CIRDES, 01 BP 454, Bobo-Dioulasso, Burkina Faso, michel.havard@,cirad.fr $\ltimes$

Laure Hossard, Inra, La Gaillarde, B27, 2 place Pierre Viala, 34000 Montpellier, France, laure.hossard@inra.fr $\lll$

Françoise Jarrige, Inra, La Gaillarde, B27, 2 place Pierre Viala, 34000 Montpellier, France, francoise.jarrige@supagro.fr $₫$

Lucette Laurens, Inra, La Gaillarde, B27, 2 place Pierre Viala, 34000 Montpellier, France, lucette.laurens@supagro.inra.fr $\$

Pierre-Yves Le Gal, Cirad, TA C-85/15, 73 rue Jean-François Breton, 34398 Montpellier Cedex 5, France, pierre-yves.le_gal@cirad.fr $\$

Ismail M. Moumouni, Faculty of Agronomy, University of Parakou, BP 123, Parakou, Benin, ismail.moumouni@fa-up.bj «

Delphine Marie-Vivien, Cirad/MALICA, Consortium CASRAD-FAVRIRUDEC-CIRAD, 298 Kim Ma, Bldg 2G, Hanoi, Vietnam, delphine.marievivien@,cirad.fr $\lll$

Laura Michel, University of Montpellier, Faculty of Law and Political Science, 39 rue de l'Université, 34060 Montpellier cedex 2, France, laura.michel@umontpellier.fr $\lll$

Isabelle Michel, IRC, Lavalette, 1101 avenue Agropolis, BP 5098, 34093 Montpellier Cedex 5, France, isabelle.michel@supagro.fr $ᄍ$

Sébastien Mouret, Inra, La Gaillarde, B27, 2 place Pierre Viala, 34000 Montpellier, France, mouret_s@hotmail.com $\$ 
Brigitte Nougarèdes, Inra, La Gaillarde, B27, 2 place Pierre Viala, 34000 Montpellier, France, brigitte.nougaredes@inra.fr $\lll$

Dominique Paturel, Inra, La Gaillarde, B27, 2 place Pierre Viala, 34000 Montpellier, France, dominique.paturel@inra.fr \ᄍ

Philippe Pedelahore, African Intellectual Property Organization (OAPI), 158 place de la Préfecture, BP 887, Yaoundé, Cameroon, philippe.pedelahore@cirad.fr $\lll$

Éric Penot, Cirad, TA C-85/15, 73 rue Jean-François Breton, 34398 Montpellier Cedex 5, France, eric.penot@cirad.fr $\lll$

Coline Perrin, Inra, La Gaillarde, B27, 2 place Pierre Viala, 34000 Montpellier, France, coline.perrin@inra.fr $\lll$

Jocelyne Porcher, Inra, La Gaillarde, B27, 2 place Pierre Viala, 34000 Montpellier, France, jocelyne.porcher@inra.fr $₫$

Sylvain Quiédeville, FIBL Ackerstrasse 113, 5070 Frick, Switzerland, sylvain.quiedeville@fibl.org \ᄍ

Pierre Rebuffel, Cirad, TA C-85/15, 73 rue Jean-François Breton, 34398 Montpellier Cedex 5, France, pierre.rebuffel@cirad.fr $\lll$

Ophélie Robineau, Cirad, TA C-85/15, 73 rue Jean-François Breton, 34398 Montpellier Cedex 5, France, robineauophelie@gmail.com $\$

Claire Ruault, Gerdal (Groupe d'expérimentation et de recherche : développement et actions locales), La Houdinais, 35160 Le Verger, France, c.gerdal.ruault@wanadoo.fr $x$

Denis Sautier, Cirad, TA C-85/15, 73 rue Jean-François Breton, 34398 Montpellier Cedex 5, France, denis.sautier@cirad.fr \

Pascale Scheromm, Inra, La Gaillarde, B27, 2 place Pierre Viala, 34000 Montpellier, France, pascale.scheromm@inra.fr $₫$

Nicole Sibelet, Cirad, TA C-85/15, 73 rue Jean-François Breton, 34398 
Montpellier Cedex 5, France, nicole.sibelet@cirad.fr $₫$

Zayda Sierra, Faculty of Education, University of Antioquia, calle 67 No. 53

- 108 - 9-111, Medellín, Colombia, sierrazayda@yahoo.com $\lll$

Luanda Sito, University of Antioquia, Sede principal, Calle $67 n^{\circ} 53-108-$ 9-144, Medellín, Colombia, luanda.soares@udea.edu.co $\lll$

Christophe-Toussaint Soulard, Inra, La Gaillarde, B27, 2 place Pierre Viala, 34000 Montpellier, France, christophe.soulard@inra.fr $₫$

Fabien Stark, Agreenium, 42 rue Scheffer, 75016 Paris, France,

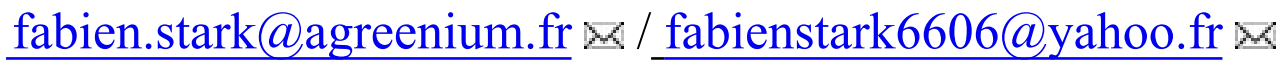
Hélène Tallon, hameau d'Ichis, 34390 Prémian, France, htallon@gmail.com

Ludovic Temple, Cirad, TA C-85/15, 73 rue Jean-François Breton, 34398 Montpellier Cedex 5, France, ludovic.temple@cirad.fr $₫$

Aurélie Toillier, CEDRES, 03 BP 7210, Ouagadougou 03, Burkina Faso, aurelie.toillier@,cirad.fræᄍ

Jean-Marc Touzard, Inra, La Gaillarde, B27, 2 place Pierre Viala, 34000 Montpellier, France, jean-marc.touzard@inra.fr $\lll$

Guy Trebuil, Cirad, TA C-85/15, 73 rue Jean-François Breton, 34398 Montpellier Cedex 5, France, guy.trebuil@cirad.fr $\$

Gerardo Ubilla Bravo, Inra, La Gaillarde, B27, 2 place Pierre Viala, 34000 Montpellier, France, gerardo.ubilla bravo@yahoo. \巛 


\section{Synthèses}

\section{Innovation and development in agricultural and food systems}

Guy Faure, Yuna Chiffoleau, Frédéric Goulet, Ludovic Temple and Jean-Marc Touzard, editors

Afterword : Gaël Giraud

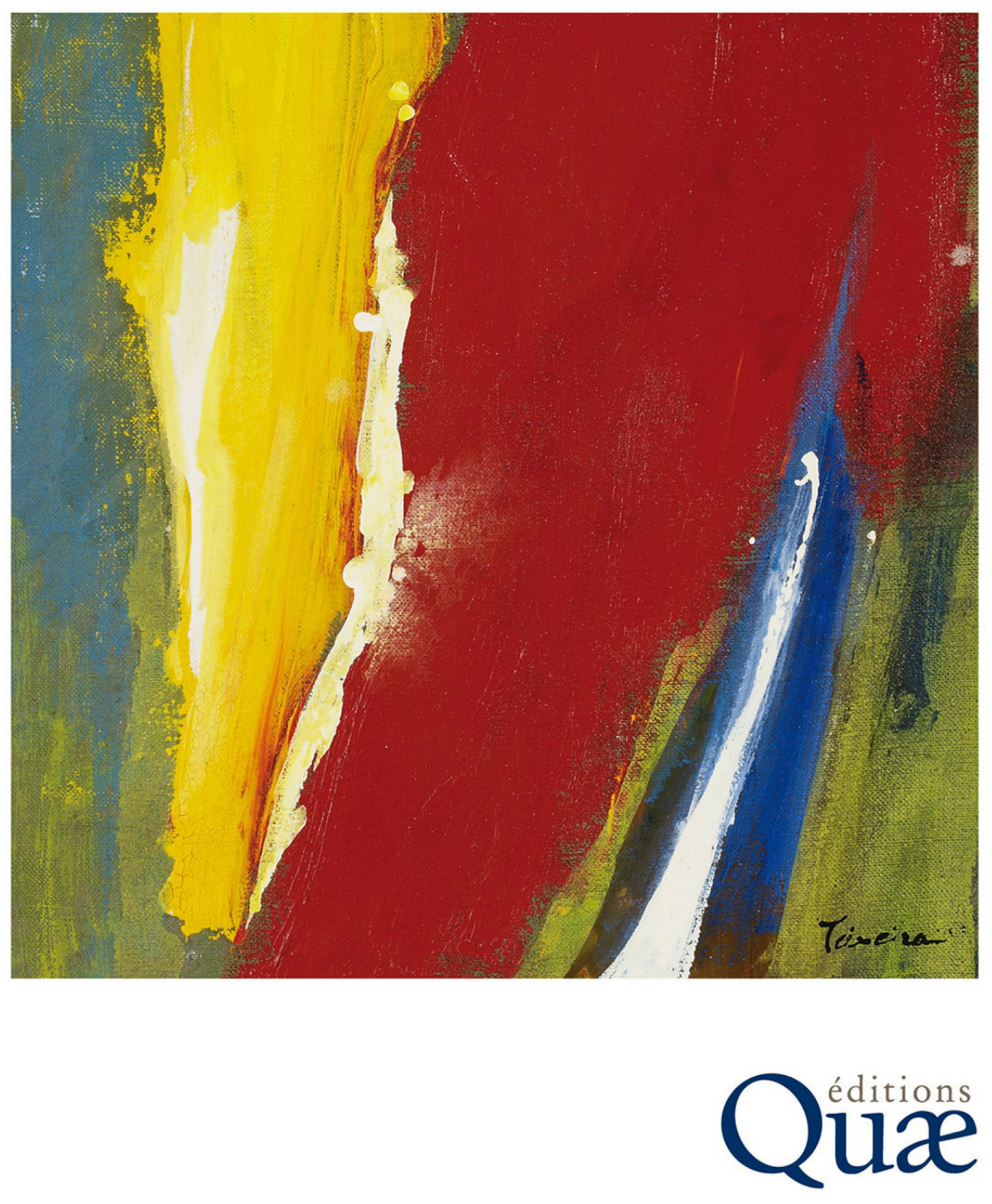


